\title{
Interactions of cadmium, zinc, and phosphorus in marine Synechococcus: Field uptake, physiological and proteomic studies
}

\author{
By \\ Alysia Danielle Cox \\ B.S. summa cum laude in Geological Sciences \\ Arizona State University, Barrett Honors College, 2004 \\ Submitted in partial fulfillment of the requirements for the degree of \\ Doctor of Philosophy \\ at the

\begin{abstract}
MASSACHUSETTS INSTITUTE OF TECHNOLOGY
and the

WOODS HOLE OCEANOGRAPHIC INSTITUTION
\end{abstract}

June 2011

(c) 2011 Alysia Cox

All rights reserved.

The author hereby grants to MIT and WHOI permission to reproduce and to distribute publicly paper and electronic copies of this thesis document in whole or in part in any medium now known or hereafter created.

Signature of Author:

Joint Program in Chemical Oceanography Massachusetts Institute of Technology and Woods Hole Oceanographic Institution May $3^{\text {rd }}, 2011$

Certified by:

Dr. Mak A. Saito

Thesis Supervisor

Accepted by:

Dr. Roger E. Summons

Professor of Earth, Atmospheric and Planetary Sciences Chair, Joint Committee for Chemical Oceanography 


\title{
Interactions of cadmium, zinc, and phosphorus in marine Synechococcus: Field uptake, physiological and proteomic studies
}

\author{
By \\ Alysia D. Cox \\ Submitted to the Department of Marine Chemistry and Geochemistry, \\ Massachusetts Institute of Technology-Woods Hole Oceanographic Institution, \\ Joint Program in Oceanography \\ on May 3rd, 2011, in partial fulfillment of the requirements for the degree of \\ Doctor of Philosophy
}

\begin{abstract}
A combination of uptake field studies on natural phytoplankton assemblages and laboratory proteomic and physiological experiments on cyanobacterial isolates were conducted investigating the interactions of cadmium $(\mathrm{Cd})$, zinc $(\mathrm{Zn})$, and phosphorus $(\mathrm{P})$ in marine Synechococcus. Enriched stable isotope field uptake studies of ${ }^{110} \mathrm{Cd}$ in the Costa Rica Upwelling dome, a Synechococcus feature, showed that uptake of Cd occurs in waters shallower than $40 \mathrm{~m}$, correlates positively with chlorophyll $a$ concentrations and is roughly equivalent to the calculated upwelling flux of cadmium inside the dome. In laboratory experiments, Synechococcus WH5701 cells exposed to low picomolar quantities of free $\mathrm{Cd}$ under $\mathrm{Zn}$ deficiency show similar growth rates to no added $\mathrm{Cd}$ treatments during exponential growth phase, but show differences in relative abundances of many proteins involved in carbon and sulfur metabolism suggesting a great metabolic impact. During stationary phase, chronic Cd exposure in this coastal isolate causes an increase in relative chlorophyll $a$ fluorescence and faster mortality rates. The interactions of acute $\mathrm{Cd}$ exposure at low picomolar levels with $\mathrm{Zn}$ and phosphate $\left(\mathrm{PO}_{4}{ }^{3-}\right)$ were investigated in Synechococcus WH8102, an open ocean isolate. The presence of $\mathrm{Zn}$ appears vital to the response of the organism to different $\mathrm{PO}_{4}{ }^{3-}$ concentrations. Comparisons with literature transcriptome analyses of $\mathrm{PO}_{4}{ }^{3-}$ stress show similar increases in relative abundance of $\mathrm{PO}_{4}{ }^{3-}$ stress response proteins including a $\mathrm{PO}_{4}{ }^{3-}$ binding protein and a $\mathrm{Zn}$-requiring alkaline phosphatase. A bacterial metallothionein, a $\mathrm{Zn}$-associated protein, appears to be correlated with proteins present under low $\mathrm{PO}_{4}{ }^{3-}$ conditions. Together, these experiments suggest that the interactions of $\mathrm{Cd}$ and $\mathrm{Zn}$ can affect Synechococcus and play a role in the acquisition of $\mathrm{PO}_{4}{ }^{3-}$.

Thesis Supervisor:

Mak A. Saito

Title: Associate Scientist, Marine Chemistry and Geochemistry Department, Woods Hole Oceanographic Institution
\end{abstract}




\section{Acknowledgements}

There are many people that have helped me throughout the duration of this $\mathrm{PhD}$ work. I would especially like to thank my advisor, Mak Saito, for allowing me to work in his group, pursue my own ideas, and in general make my day-to-day research possible. I would like to thank my committee members Ed Boyle, Carl Lamborg, Nigel Robinson and Sonya Dyhrman for great discussion, suggestions whenever I needed them and willingness to be available for committee meetings. In particular, I thank Ed for his excellent inorganic perspective, especially his comments on Chapter 2; Carl for his discussion about many topics and in particular comments on Chapter 2; Nigel for his biological insight and advice on metallothioneins; and Sonya for her astute advice on culturing/analysis and helping me navigate the phosphorus literature.

I would like to thank the members of the Saito Laboratory, past and present; they are excellent people with whom to work and I cannot them enough for their positive attitudes and amazing work ethics: Erin Bertrand, Vladimir Bulygin, Tyler Goepfert, Dawn Moran, Abigail Noble, Daniel Tabersky and Anne Thompson. In particular, I thank Erin for keeping the mass spectrometry operational (Chapter 3 and 4), Vladimir for developing the extraction protocol that I used in Chapters 3 and 4 and help with protein chemistry, Tyler for fixing anything that broke and help with the color scheme in Chapter 4, Dawn for the starting recipe of the culture media, Abigail for dissolved cadmium measurements in Chapter 2, Daniel for help with experimental spectroscopic measurements, and Anne for flow cytometry cell numbers in Chapter 2.

I would also like to thank John Waterbury and Freddie Valois for the strains of Synechococcus, use of lab space, and discussion and Tristan Kading for low molecular weight thiol measurements in Chapter 3 and critical editing this thesis.

Thank you to Meg Tivey, former Marine Chemistry and Geochemistry Education Coordinator for much perspective over the years and for chairing my defense. I would also like to thank the Academic Programs Office for support on everyday details and travel to conferences especially Julia Westwater, Marsha Gomes, Jim Yoder, and also Ronni Schwartz (MIT JP Office). Thank you also to Mary Zawoysky, Susan Tomeo, and Shelia Clifford for assistance. Thank you to my officemates, who have always been up for poignant discussion: Abigail, Caitlin, and Tristan. I would also like to thank the Captains (Kent Sheasley and George Gunther), crews and chief scientists (Mak Saito and Joseph Montoya) of the RV Knorr and RV Seward Johnson for facilitating smooth research at sea. Thank you to Phil Gschwend and Everett Shock for inspiration.

Thanks to the Hyannis capoeristas: Anna, JP, Bernie, Verity, Santiago, Travis, Lauren, Dan, George, Caitlin, Liz, Tristan and Bethanie for keeping it real.

Thanks to all of my housemates (who also happen to be my friends) who made home a fun place to be: Ken Whelan, Abigail Noble, Cim Wortham, Luc Mehl, Andrew McDonnell, Kelton McMahon, Caitlin Frame, Marissa Black, Jason Black and John Jacob.

Thanks to my friends and fellow students, both near and far, for good times: Cara Fosdick, Brian Buczkowski, John Cartner, Verity Salmon, Michelle Bringer, Fern Gibbons, Nathaniel Green, Anne Rounds, Des Plata, Travis Meador, Taylor Crockford, 
Li Ling Hamady, Alyson Santoro, Ben Hodges, Annette Hynes, Jessie Kneeland, Eoghan Reeves, and others among the JP students.

And finally, I would especially like to thank my family and cousins, because they are truly the best and I would not be here without them: cousins - Renee, Courtney, Ryan, and Jude and my family - Patrick, Gayla, Caitlin, and Alaina.

"We are the flow, we are the ebb, we are the weavers, we are the WEB"

- Shekhinah Mountainwater

To this incomplete WEB of people who have influenced my thoughts of science, thank you:

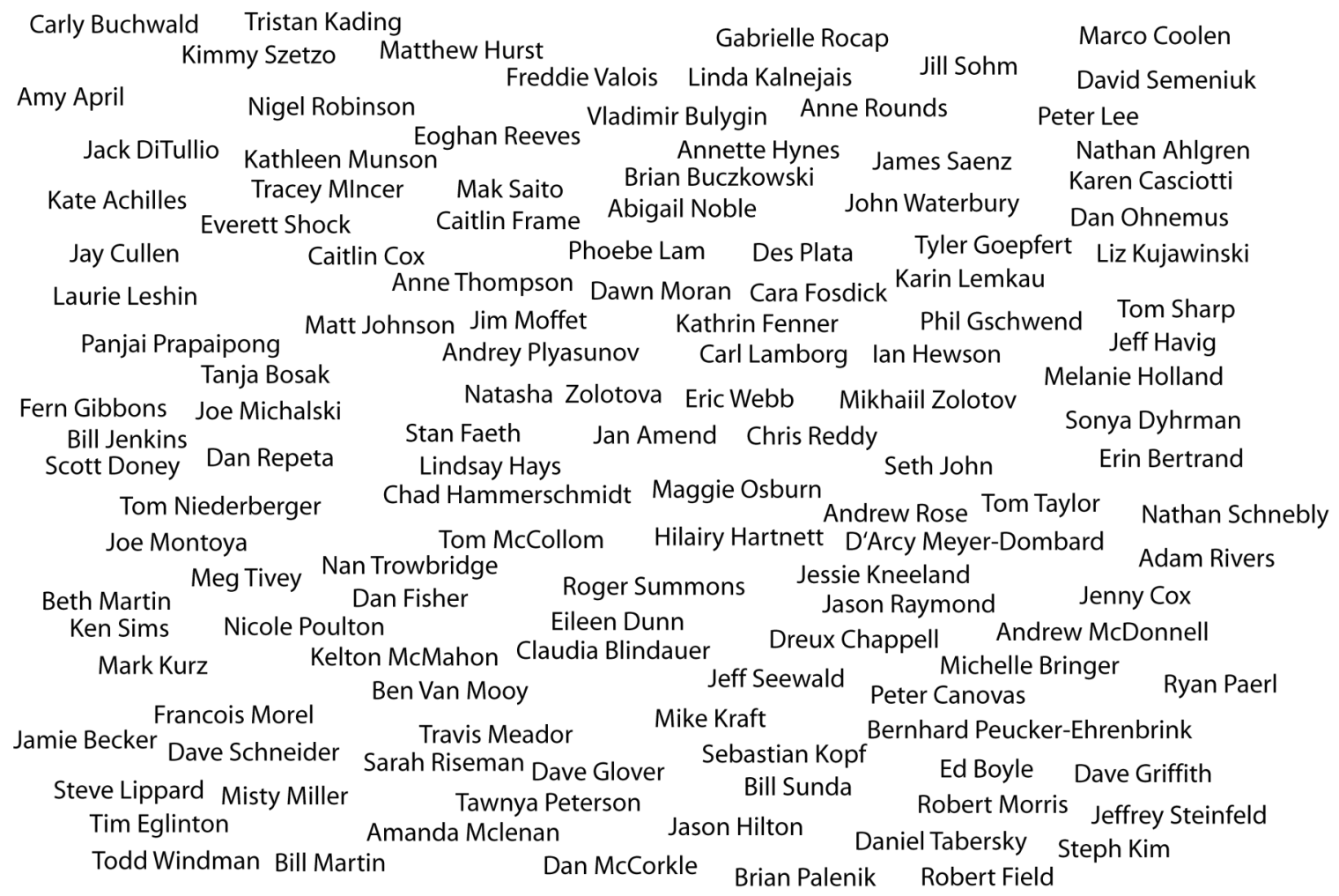

The work in this thesis was supported by a MIT Presidential Graduate Fellowship for one year, the Academic Programs Office for one semester, and awards to Mak Saito from the Office of Naval Research for three years. Funding awards to Mak Saito from NSF Chemical Oceanography, the Center for Microbial Oceanography Research and Education, and WHOI Ocean Life Institute also supported this research. 
After the last river has been poisoned

Only after the last fish has been caught

Then you will find that money cannot be eaten.

-- Cree prophecy --

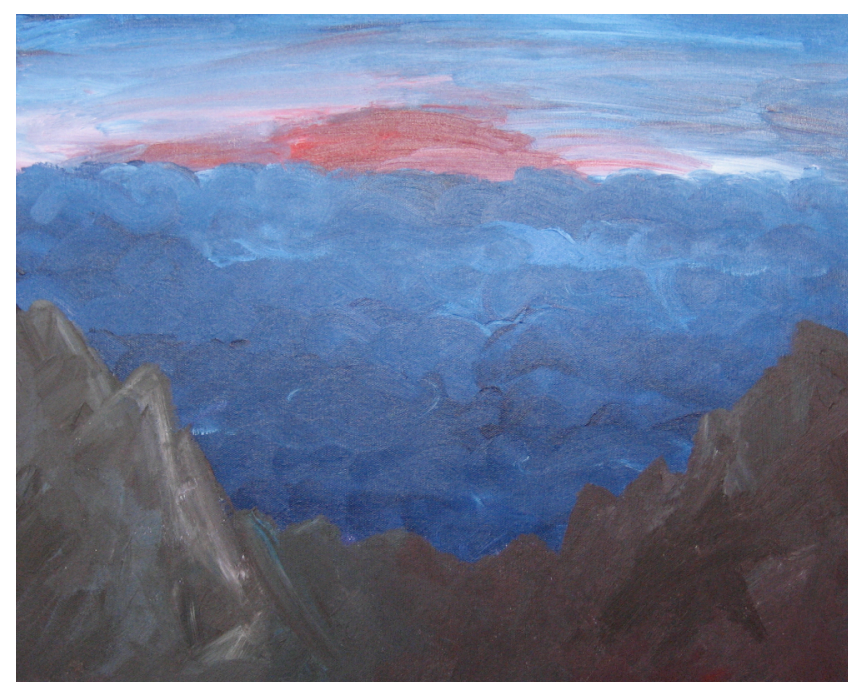

For those who come after 


\section{Table of Contents}

$\begin{array}{lc}\text { List of Figures } & 8\end{array}$

$\begin{array}{ll}\text { List of Tables } & 10\end{array}$

Chapter 1: Introduction 13

Chapter 2: Enriched stable isotope uptake and cadmium addition experiments with natural picophytoplankton assemblages in the Costa Rica Upwelling Dome

Chapter 3: Zinc-deprived coastal Synechococcus WH5701 show physiological and strong proteomic response to low picomolar chronic cadmium stress

Chapter 4: Oceanic Synechococcus WH8102 physiological and proteomic response to low picomolar acute cadmium stress under a matrix of zinc and phosphate conditions

$\begin{array}{lr}\text { Chapter 5: Conclusions } & 215\end{array}$

Appendix I: Supplementary Data to Chapter 2 219

Appendix II: Supplementary Data to Chapter 3

Appendix III: Supplementary Data to Chapter 4 


\section{List of Figures}

Figure 1.1 General Cd profile in the open ocean 16

Figure 1.2 $\mathrm{Cd}^{2+}$ in the dissolved phase in seawater 17

Figure 1.3 $\quad \mathrm{Cd}^{2+}$ in the particulate phase in seawater 18

Figure 1.4 $\mathrm{Cd}^{2+}$ inside a cell 19

$\begin{array}{lll}\text { Figure 1.5 Metallothionein } & 21\end{array}$

Figure 1.6 Possible metal binding moieties in cells 24

Figure 1.7 Original isolation locations of Synechococcus WH strains 26

Figure 2.1 Costa Rice Upwelling Dome Stations, July-August 2005

Figure 2.2 Relative abundances of stable Cd isotopes 39

Figure 2.3 General protocol to measure particulate ${ }^{110} \mathrm{Cd}$ uptake and dissolved $\mathrm{Cd}$ speciation and totals $\quad 47$

Figure 2.4 Depth profiles of natural total dissolved Cd, total dissolved Cd after adding

${ }^{110} \mathrm{Cd}$ spike, particulate Cd uptake rate, Synechococcus and Prochlorococcus

cell numbers, and total and size-fractionated chlorophyll $a$ : Inside the dome 50

Figure 2.5 Depth profiles of particulate Cd isotope ratios: Inside the dome 52

Figure $2.6 \quad{ }^{114} \mathrm{Cd} /{ }^{110} \mathrm{Cd},{ }^{111} \mathrm{Cd} /{ }^{110} \mathrm{Cd}$ and ${ }^{114} \mathrm{Cd} /{ }^{111} \mathrm{Cd}$ particulate $\mathrm{Cd}$ ratios with time: Inside the dome

Figure 2.7 Depth profiles of natural total dissolved $\mathrm{Cd}$, total dissolved Cd after adding

${ }^{110} \mathrm{Cd}$ spike, particulate Cd uptake rate, Synechococcus and Prochlorococcus cell number, and total and size-fractionated chlorophyll $a$ :

Outside the dome $\quad 54$

Figure 2.8 $\quad{ }^{110} \mathrm{Cd}$ uptake vs. time $\quad 55$

Figure 2.9 Particulate ${ }^{110} \mathrm{Cd}$ vs. time: Station 7, inside the dome 56

Figure 2.10 Initial chlorophyll $a$ and cyanobacterial cell numbers, $\mathrm{Cd}^{2+}$ addition experiments 57

Figure 2.11 Chlorophyll $a$ concentrations with added $\mathrm{Cd}^{2+}$ for four stations $\quad 58$

Figure 2.12 Maximum Cd uptake rates, Synechococcus and Prochlorococcus

Figure 2.13 Calculating upwelling and uptake fluxes of $\mathrm{Cd} \quad 66$

Figure 2.14 One box model of Cd geochemistry 66

Figure 3.1 Relative chlorophyll $a$ fluorescence vs. time: no $\mathrm{Zn}^{2+}$ added, $\mathrm{Cd}^{2+} \quad 79$

Figure 3.2 Growth rate, maximum chlorophyll $a$ fluorescence, and mortality rate: no $\mathrm{Zn}^{2+}$ added, $\mathrm{Cd}^{2+}$

Figure 3.3 Relative chlorophyll $a$ fluorescence vs. time: $\mathrm{Zn}^{2+}$ and no $\mathrm{Zn}^{2+}$ added, $\mathrm{Cd}^{2+} 81$

Figure 3.4 Natural logarithm of cell number, chlorophyll $a$ fluorescence, phycoerythrin fluorescence, and ratio of chlorophyll $a$ /phycoerythrin fluorescence vs. time: no $\mathrm{Zn}^{2+}$ added, $\mathrm{Cd}^{2+} \quad 82$

$\begin{array}{lll}\text { Figure 3.5 Cluster analysis of relative protein abundance } & 87\end{array}$

$\begin{array}{ll}\text { Figure 3.6 } & \text { Number of identified proteins differentially more abundant by } \\ \text { two-fold or more per time point } & 88\end{array}$

Figure 3.7 Relative protein abundance: exponential growth phase 90 
Figure 3.8

Figure 3.9

Figure 3.10

Figure 3.11

Figure 3.12

Figure 3.13

Figure 3.14

Figure 3.15

Figure 3.16

Figure 3.17

Figure 3.18

Figure 3.19

Figure 3.20

Figure 3.21

Figure 4.1

Figure 4.2

Figure 4.3

Figure 4.4

Figure 4.5

Figure 4.6

Figure 4.7

Figure 4.8

Figure 4.9

Figure 4.10

Figure 4.11

Figure 4.12

Figure III.1

Figure III.2
Relative protein abundance vs. time: Chlorophyll $a$ biosynthesis

103

Relative protein abundance vs. time: Photosynthesis (phycobilisome) 108

Relative protein abundance vs. time: Photosynthesis (photosystem II) 112

Relative protein abundance vs. time: Photosynthesis (photosystem I) 115

Relative protein abundance vs. time: Photosynthesis

(ferredoxin and ATP synthase)

120

Relative protein abundance vs. time: Carbon fixation

(carboxysome-associated)

125

129

132

137

149

Relative protein abundance vs. time: Oxidative stress

141

144

145

147

\section{Chapter 4: Acute $\mathrm{Cd}^{2+}$ Synechococcus WH8102}

Experimental design

Physiological data: chlorophyll $a$ fluorescence, phycoerythrin fluorescence, and ratio of chlorophyll $a$ /phycoerythrin fluorescence 168

Physiological data: cell numbers vs. time 169

$\begin{array}{ll}\text { Growth rates before and after Cd addition } & 170\end{array}$

Cell numbers at harvest $\quad 170$

Ratio of chlorophyll $a$ to phycoerythrin fluorescence per cell 172

$\begin{array}{ll}\text { Cluster analysis of relative protein abundance } & 174\end{array}$

Number of proteins two-fold or more differentially abundant 176

Relative protein abundance of bacterial metallothionein (SmtA), putative

alkaline phosphatase and ABC phosphate transporter (PstS) 178

Relative protein abundance of proteins $\geq$ two-fold greater in abundance and/or statistically different by Fisher's Exact Test in the no Zn-high $\mathrm{PO}_{4}{ }^{3-}$ $+4.4 \mathrm{pM} \mathrm{Cd}^{2+}$ compared to no $\mathrm{Zn}$-high $\mathrm{PO}_{4}{ }^{3-}$

185

Relative protein abundance of proteins $\geq$ two-fold less in abundance and/ or statistically different by Fisher's Exact Test in the no Zn-high $\mathrm{PO}_{4}{ }^{3-}$ $+4.4 \mathrm{pM} \mathrm{Cd}^{2+}$ compared to no $\mathrm{Zn}$-high $\mathrm{PO}_{4}{ }^{3-}$

Fold change in protein relative abundance (this chapter) vs. $\log _{2}$ fold

change in transcript relative abundance (Tetu et al., 2009)

Appendix III

Phycoerythrin fluorescence vs. time: chronic $\mathrm{PO}_{4}{ }^{3-}$ limitation

reconnaissance study

235

Growth rates by phycoerythrin before and after $\mathrm{Cd}$ addition 


\section{List of Tables}

Table 2.1 Cd natural isotope abundance and isotope ratios

Table 2.2 Calculated particulate ${ }^{110} \mathrm{Cd}$ uptake rates from time course experiments and one 24-hour point

Table 2.3 Initial conditions and chlorophyll $a$ results from $\mathrm{Cd}$ addition experiments

Maximum particulate cadmium uptake rates, cyanobacterial cell counts, and chlorophyll $a$ concentrations

Table 3.1

Chapter 3: Chronic $\mathrm{Cd}^{2+}$ Synechococcus WH5701

$\begin{array}{ll}\text { in } \mathrm{Cd}^{2+} \text { treatments than no added } \mathrm{Cd}^{2+} \text { by } \geq \text { two-fold } \\ \text { Table 3.2 } & \text { WH5701 proteins during exponential growth phase (T1) less abundant }\end{array}$ in $\mathrm{Cd}^{2+}$ treatments than no added $\mathrm{Cd}^{2+}$ by $>$ two-fold

WH5701 proteins during very late stationary or death phase (T5)

more abundant in $\mathrm{Cd}^{2+}$ treatments than no added $\mathrm{Cd}^{2+}$ by $\geq$ two-fold 96

Table 3.4 WH5701 proteins during very late stationary or death phase (T5)

less abundant in $\mathrm{Cd}^{2+}$ treatments than no added $\mathrm{Cd}^{2+}$ by $\geq$ two-fold

Chapter 4: Acute $\mathrm{Cd}^{2+}$ Synechococcus WH8102

Table 4.1 WH8102 proteins that are $\geq$ two-fold differentially abundant in $\mathrm{Zn}$ $1 \mu \mathrm{M} \mathrm{PO}_{4}{ }^{3-}$ (low $\mathrm{PO}_{4}{ }^{3-}$ ) than the $\mathrm{Zn}-65 \mu \mathrm{M} \mathrm{PO}_{4}{ }^{3-}$ (high $\mathrm{PO}_{4}{ }^{3-}$ )

Table 4.2 WH8102 proteins that are strongly upregulated ( $\geq$ two-fold) under early $\mathrm{PO}_{4}{ }^{3-}$-stress according to transcriptome analysis in Tetu (2009), but not $\geq$ two-fold differentially abundant according to our global proteomic analysis, $\mathrm{Zn}-1 \mu \mathrm{M} \mathrm{PO}_{4}{ }^{3-}\left(\mathrm{Zn}-\right.$ low $\left.\mathrm{PO}_{4}{ }^{3-}\right)$ than the $\mathrm{Zn}-65 \mu \mathrm{M} \mathrm{PO}_{4}{ }^{3-}$ $\left(\mathrm{Zn}\right.$-high $\mathrm{PO}_{4}{ }^{3-}$ )

Table 4.3 WH8102 proteins that are $\geq$ two-fold differentially abundant in the no Znlow $\mathrm{PO}_{4}^{3-}$ than the no $\mathrm{Zn}$-high $\mathrm{PO}_{4}{ }^{3-}$

Table 4.4 WH8102 proteins that are $\geq$ two-fold differentially abundant in the no $\mathrm{Zn}$ high $\mathrm{PO}_{4}{ }^{3-}$ and no $\mathrm{Zn}$-high $\mathrm{PO}_{4}{ }^{3-}+4.4 \mathrm{pM} \mathrm{Cd}^{2+}$

Table 4.5 Additional WH8102 proteins that are $\geq$ two-fold differentially abundant in the no $\mathrm{Zn}$-high $\mathrm{PO}_{4}{ }^{3-}$ than the no $\mathrm{Zn}$-high $\mathrm{PO}_{4}{ }^{3-}+4.4 \mathrm{pM} \mathrm{Cd}^{2+}$ according to Fisher's Exact Test

Appendix I

Table I.1 Costa Rica Upwelling Dome station locations

Table I.2 Particulate cadmium uptake, cyanobacterial cell number, and chlorophyll $a$ : Inside the dome

Table I.3 Particulate cadmium uptake, cyanobacterial cell number, and chlorophyll $a$ : Outside the dome

Table I.4

$\mathrm{Cd}$ isotope ratios: Inside the dome

Table 1.5

Cd uptake rates, time course experiment 


\section{Appendix II}

Table II.1 WH5701 proteins during early stationary phase (T2) more abundant in $\mathrm{Cd}^{2+}$ treatments than no added $\mathrm{Cd}^{2+}$ by $\geq$ two-fold

Table II.2 WH5701 proteins during early stationary phase (T2) less abundant in $\mathrm{Cd}^{2+}$ treatments than no added $\mathrm{Cd}^{2+}$ by $\geq$ two-fold

Table II.3 WH5701 proteins during mid-stationary phase (T3) more abundant in $\mathrm{Cd}^{2+}$ treatments than no added $\mathrm{Cd}^{2+}$ by $\geq$ two-fold

Table II.4 WH5701 proteins during mid-stationary phase (T3) less abundant in $\mathrm{Cd}^{2+}$ treatments than no added $\mathrm{Cd}^{2+}$ by $\geq$ two-fold

Table II.5 WH5701 proteins during late stationary phase (T4) more abundant in $\mathrm{Cd}^{2+}$ treatments than no added $\mathrm{Cd}^{2+}$ by $\geq$ two-fold

Table II.6 WH5701 proteins during late stationary phase (T4) less abundant in $\mathrm{Cd}^{2+}$ treatments than no added $\mathrm{Cd}^{2+}$ by $\geq$ two-fold

Appendix III

Table III.1 WH8102 proteins that are $\geq$ two-fold abundant in the $\mathrm{Zn}$-low $\mathrm{PO}_{4}{ }^{3-}$ +4.4 pM Cd${ }^{2+}$ vs. $\mathrm{Zn}-$ high $\mathrm{PO}_{4}{ }^{3-}+4.4 \mathrm{pM} \mathrm{Cd}^{2+}$

Table III.2 WH8102 proteins that are $\geq$ two-fold abundant in the no $\mathrm{Zn}$-low $\mathrm{PO}_{4}{ }^{3-}+4.4 \mathrm{pM} \mathrm{Cd}^{2+}$ vs. no Zn-high $\mathrm{PO}_{4}{ }^{3-}+4.4 \mathrm{pM} \mathrm{Cd}^{2+}$

Table III.3 WH8102 proteins that are $\geq$ two-fold abundant in the $\mathrm{Zn}$-high $\mathrm{PO}_{4}{ }^{3-}$ $+4.4 \mathrm{pM} \mathrm{Cd}^{2+}$ vs. Zn-high $\mathrm{PO}_{4}{ }^{3-}$

WH8102 proteins that are $\geq$ two-fold abundant in the no $\mathrm{Zn}$-low $\mathrm{PO}_{4}{ }^{3-}$

$\begin{array}{ll}\text { Table III.4 } & \text { WH8102 proteins that are } \geq \text { two-fo } \\ & +4.4 \mathrm{pM} \mathrm{Cd}^{2+} \text { vs. no } \mathrm{Zn}-\mathrm{low} \mathrm{PO}_{4}{ }^{3-}\end{array}$

Table III.5 WH8102 proteins that are $\geq$ two-fold abundant in the $\mathrm{Zn}-$ low $\mathrm{PO}_{4}{ }^{3-}$ $+4.4 \mathrm{pM} \mathrm{Cd}^{2+}$ vs. Zn-low $\mathrm{PO}_{4}{ }^{3-}$

WH8102 proteins that $\geq$ two-fold abundant in the no $\mathrm{Zn}$-high $\mathrm{PO}_{4}{ }^{3-}$ phosphate vs. Zn-high $\mathrm{PO}_{4}{ }^{3-}$

Table III.6

Table III.7

WH8102 proteins that $\geq$ two-fold abundant in the no $\mathrm{Zn}$-low $\mathrm{PO}_{4}{ }^{3-}$ vs. $\mathrm{Zn}$-low $\mathrm{PO}_{4}{ }^{3-}$

Table III.8

WH8102 proteins that $\geq$ two-fold abundant in the no $\mathrm{Zn}$-high $\mathrm{PO}_{4}{ }^{3-}$ $+4.4 \mathrm{pM} \mathrm{Cd}^{2+}$ vs. Zn-high $\mathrm{PO}_{4}{ }^{3-}+4.4 \mathrm{pM} \mathrm{Cd}^{2+}$

Table III.9

WH8102 proteins that are $\geq$ two-fold abundant in the no $\mathrm{Zn}$-low $\mathrm{PO}_{4}{ }^{3-}$ $+4.4 \mathrm{pM} \mathrm{Cd}^{2+}$ vs. Zn-low $\mathrm{PO}_{4}{ }^{3-}+4.4 \mathrm{pM} \mathrm{Cd}^{2+}$

Table III.10 WH8102 proteins that are $\geq$ two-fold abundant in the no $\mathrm{Zn}$-high $\mathrm{PO}_{4}{ }^{3-}$ $+4.4 \mathrm{pM} \mathrm{Cd}^{2+}$ vs. Zn-high $\mathrm{PO}_{4}^{3-}$ 


\section{Chapter 1: Introduction}

Consider the earth, an approximately 4.5 billion year old differentiated planet with a radius of roughly 6,400 kilometers. The crustal thickness of earth is close to 40 kilometers and oceans cover around 70\% of the earth's surface. Much of life on earth is driven by energy from the sun in the form of primary production as the base of the food chain. Primary productivity occurs on both land and the ocean. Marine primary productivity is thought to account for about $45 \%$ of total primary productivity (Falkowski, 1994; Field et al., 1998; Morel et al., 2003). Under the umbrella of marine primary productivity are dinoflagellates, diatoms, algae and cyanobacteria.

Cyanobacteria are evolutionarily ancient and have persisted through many changes in ocean chemistry, including changing metal conditions. Marine Synechococcus have developed many adaptations to horizontal gradients in nutrients and light (Scanlan, 2003). This thesis explores the response of modern Synechococcus to changes in cadmium $(\mathrm{Cd})$ and zinc $(\mathrm{Zn})$ exposure with a focus on the interactions between these two elements and the effects of each on phosphorus $(\mathrm{P})$ metabolism. Field experiments conducted in the Costa Rica Upwelling Dome, a Synechococcus feature, are presented in Chapter 2 and laboratory manipulations with axenic strains of Synechococcus are presented in Chapters 3 and 4.

\section{Cyanobacteria}

Cyanobacteria, especially marine cyanobacteria, are an integral part of the earth/life system as agents of carbon fixation and oxygen production. The marine cyanobacteria Synechococcus and Prochlorococcus contribute between 32 and $80 \%$ of the total primary productivity in oligotropic oceans (Rocap et al., 2002) and contribute about $50 \%$ of fixed carbon in some oceanic regions (Zwirglmaier et al., 2007). Synechococcus species alone are considered to be important contributors to global primary productivity and are thought to dominate phytoplankton populations throughout much of the world's oceans (Scanlan, 2003). In addition to their modern contribution to primary productivity, cyanobacteria are suspected to be responsible for the first biological oxygen generation starting around three billion years ago (Williams and Frausto da Silva, 
2006) resulting in the oxygenation of the atmosphere 2.2-2.4 billion years ago (Catling et al., 2001; Catling and Claire, 2005) and thus have played a vital role in the chemistry and evolution of life on this planet.

Cyanobacteria are ubiquitous, versatile and have been found in diverse environments ranging from desert crusts, to freshwater and hot spring environments. Cyanobacteria are unique in that their cell walls have features of both gram negative and gram positive bacteria (Hoiczyk and Hansel, 2000). Cyanobacteria also contain phycobiliproteins, which enable them to adapt to their surrounding light environment, and among the cyanobacteria a great range of spectral variation in their antenna pigments can be found (Glazer, 1989). These phycobiliproteins have been used as fluorescence tags for cell surface markers (Kresage et al., 2009). Researchers have noted the aesthetic and chemical significance of the phycobiliproteins of cyanobacteria for over 130 years: " It would be difficult to find another series of colouring matters of greater beauty or with such remarkable and instructive chemical and physical peculiarities" (Sorby, 1877).

\section{Evolution and zinc}

The evolution of cyanobacteria is closely linked to the oxygenation status of the ocean, which directly affects the speciation of $\mathrm{Zn}$ and $\mathrm{Cd}$. $\mathrm{Zn}$ is the cofactor for many proteases and vital in many enzymes. Zn was not as abundant during early evolution due to the formation of insoluble sulfide complexes (Canfield, 1998; Anbar and Knoll, 2002; Saito et al., 2003). Bacteria may have grown, operated and evolved with limited amounts of $\mathrm{Zn}$. As the oceans changed, $\mathrm{Zn}$ became more bioavailable (Saito et al., 2003). The $\mathrm{Zn}$ requirements of many cyanobacteria are very low, which is consistent with the idea that cyanobacteria may have evolved in a sulfidic ancient ocean (Saito et al., 2003). Oxygen was toxic to many microorganisms early in their evolutionary history, which suggests the onset of higher levels of $\mathrm{Zn}$ may have been toxic prior to adaptation as well (former idea - Williams and Frausto da Silva, 2006). There was an explosion in the diversity of Znbinding protein structures in eukaryotic organisms suggesting that the ocean was not anoxic or euxinic for this to occur (Dupont et al., 2006b). Because of compartmentalization, however, bacteria are able to cope with changing environmental 
chemistry. Compartmentalization is thought to be important to the evolution of environmental chemistry and life (Williams and Frausto da Silva, 2006) and the study of metal ions in compartments can provide understanding of cell and environmental evolution that the organic chemistry of cells alone cannot provide (Williams, 2007). In the modern ocean, Zn availability may influence phytoplankton diversity in the Ross Sea (Saito et al., 2010). There are almost no studies of $\mathrm{Zn}$ handling mechanisms in marine cyanobacteria (Blindauer, 2008a). This thesis explores how the addition of $\mathrm{Zn}$ can decrease the toxicity of $\mathrm{Cd}$ in Chapter 3 and the interactions of $\mathrm{Zn}$ with $\mathrm{Cd}$ and $\mathrm{P}$ in Chapter 4.

\section{Cadmium and zinc as trace metals}

$\mathrm{Cd}$ and $\mathrm{Zn}$ are both group 12 elements in the periodic table, implying a certain degree of chemical similarity. In magmatic rocks, the ratio of $\mathrm{Cd}$ to $\mathrm{Zn}$ is about 1:500 (Goldschmidt, 1954). It has been known for over half a century that the concentration of $\mathrm{Cd}$ in seawater was less than 0.005 ppm (1 nM) (Noddack and Noddack, 1939), and geochemists noticed the accumulation of $\mathrm{Cd}$ in rocks of marine origin (Goldschmidt, 1954). Only in the 1970's were accurate measurements of $\mathrm{Cd}$ and $\mathrm{Zn}$ able to be made at the $\mathrm{pM}$ to $\mathrm{nM}$ levels found in surface seawater. $\mathrm{Cd}$ and $\mathrm{Zn}$ have nutrient-like profiles, meaning they are depleted in surface waters and increase with depth (Boyle, 1976; Bruland, 1980) (Figure 1.1). Cd correlates closely with dissolved phosphate, and Zn correlates with dissolved silicate concentrations throughout the oceans. This implies that like the major nutrients, $\mathrm{Cd}$ and $\mathrm{Zn}$ are taken up by microorganisms in the surface (as discussed in Chapter 2) and resolubilized at depth. These metals may have different roles in different environments. $\mathrm{Zn}$ is considered a micronutrient in the open ocean. Toxicity of $\mathrm{Cd}$ to a coastal cyanobacterium is presented in Chapter 3.

Like many other bioactive trace metals in surface waters, dissolved $\mathrm{Cd}$ and $\mathrm{Zn}$ in the ocean are complexed by strong organic ligands (Bruland, 1980; Bruland, 1992; Ellwood and van den Berg, 2000; Ellwood, 2004, and Morel et al., 2003). Whether or not $\mathrm{Cd}$ functions as a nutrient or toxin is likely to be controlled by its bioavailability. The bioavailability, in turn, is controlled by the speciation of trace metals (Hunter et al., 1997) 
(Figure 1.2). In many studies, toxicity has been proportional to the summation of inorganic metal species added to the media (Sunda, 1988), although for copper and iron, organic ligands have been shown to be bioavailable (Hutchins et al., 1999; Maldonado et al., 1999; Quigg et al., 2006 and Semeniuk et al., 2009). Despite the fact that the speciation of bioactive trace metals directly influences bioavailability and bioavailability likely controls the status of a trace metal as a nutrient or a toxin, only a limited number of speciation measurements have been made in the ocean for $\mathrm{Zn}$ and $\mathrm{Cd}$ (Bruland, 1980; Bruland, 1992; Ellwood and van den Berg, 2000; Ellwood, 2004).

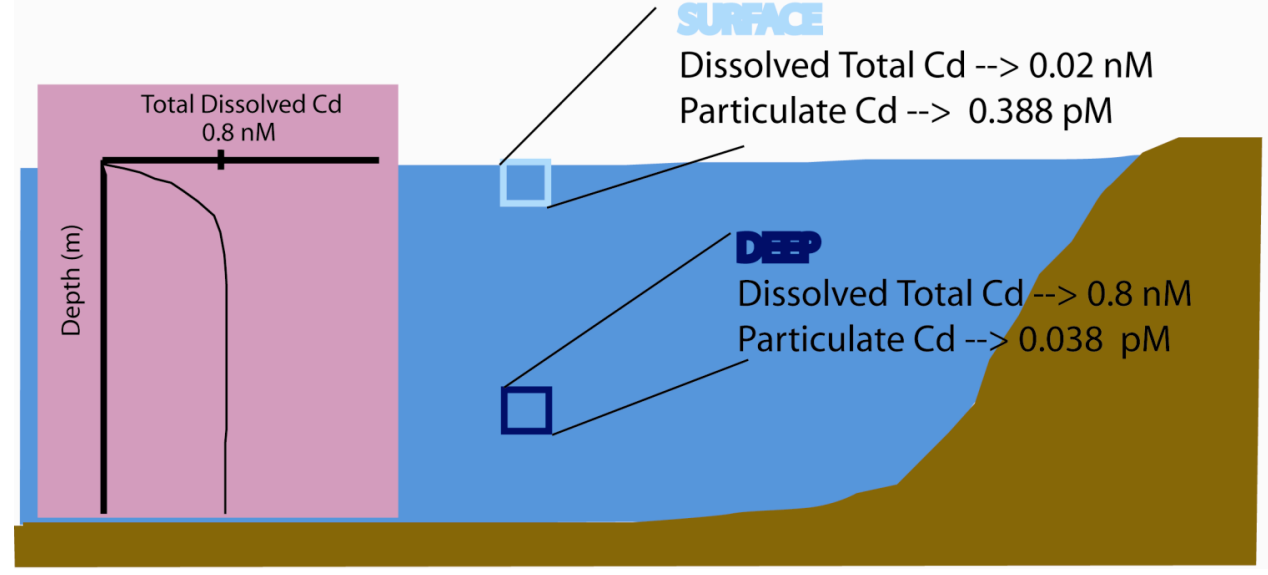

Figure 1.1: General Cd profile in the open ocean. Dissolved total $\mathrm{Cd}$ has a nutrient-like profile, closely correlated with phosphate, and reaches $0.8-1 \mathrm{nM}$ concentrations at depth. Surface waters generally have low picomolar to undetectable dissolved total Cd. With the exception of iron, which has high particulate concentrations, particulate concentrations are usually an order of magnitude lower than dissolved concentrations and there are only a few high-quality data sets that exist (Sherrell and Boyle, 1992; Cullen et al., 2001). Dissolved total Cd numbers are from the central North Pacific (Bruland, 1992). Particulate Cd numbers are from the North Atlantic near Bermuda, $50 \mathrm{~m}$ and $1450 \mathrm{~m}$ (Sherrell and Boyle, 1992). 


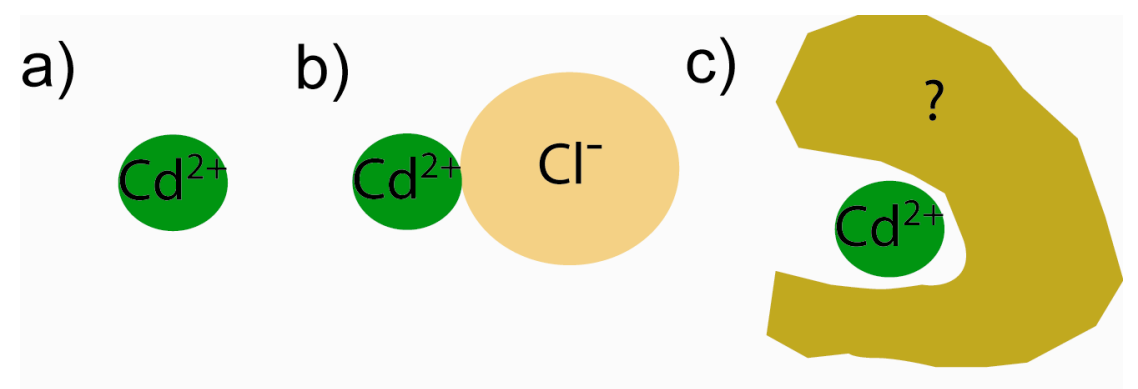

Figure 1.2: $\mathrm{Cd}^{2+}$ in the dissolved phase in seawater. a) $\mathrm{Cd}^{2+}$ as a free ion. b) $\mathrm{Cd}^{2+}$ complexed with $\mathrm{Cl}^{-}$to form $\mathrm{CdCl}^{+}$(and other chlorocomplexes) c) $\mathrm{Cd}^{2+}$ bound to organic ligands of uncertain structure and origin. Inorganic $\mathrm{Cd}^{2+}$ is mostly present as $\mathrm{CdCl}^{+}$in seawater, although $\mathrm{Cd}^{2+}$ has been found to be $70 \%$ bound to organic ligands in some surface waters. $\mathrm{Cd}^{2+}$ and $\mathrm{CdCl}^{+}$are considered to be labile and bioavailable. Cd bound to organic ligands is not thought to be bioavailable.

There are only a few datasets which consider bioactive trace metals in the particulate fraction (Sherrell and Boyle, 1992; Cullen and Sherrell, 1999; Cullen et al., 2001). With the exception of iron, particulate concentrations tend to be an order of magnitude lower than dissolved concentrations (Cullen et al., 2001 and references therein). One can envision several mechanisms for the partitioning of metal ions within the particulate fraction. Metal ions can be taken up into microorganisms, adsorbed to the surface of microorganisms, adsorbed to particulate organic matter (POM), and adsorbed to mineral surfaces (Figure 1.3). Measuring the precise mechanism of partitioning within the particulate fraction is difficult. Uptake of $\mathrm{Cd}$ by microorganisms may be responsible for concentration of $\mathrm{Cd}$ in the particulate phase. Adsorption onto the cell surface is possible but not highly probable. Researchers have experimented with extracellular washes with varying degrees of success and found adsorption of $\mathrm{Cd}$ to be minor in low metal environments (Hudson and Morel, 1989; Tovar-Sanchez et al., 2003, 2004; Tang and Morel, 2006). The role of adsorption to inorganic mineral phases in the presence of particulate organic matter has not been determined. Cd uptake experiments conducted in the field are presented in Chapter 2. 
a)

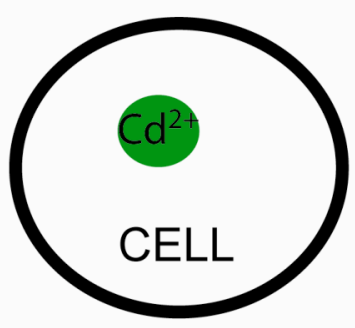

c)

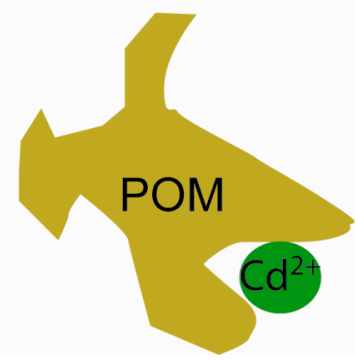

b)

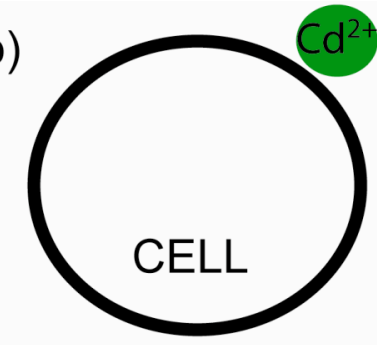

d)

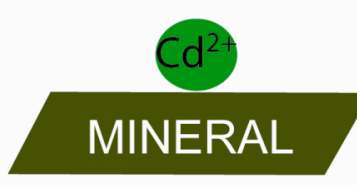

Figure 1.3: $\mathrm{Cd}^{2+}$ in the particulate phase of seawater. a) Uptake of Cd into microorganisms. b) Adsorption of $\mathrm{Cd}$ onto the surface of microorganisms. c) Adsorption of $\mathrm{Cd}^{2+}$ onto particulate organic matter (POM). d) Adsorption of Cd onto mineral surfaces. Intracellular cadmium (a) probably represents the largest fraction of $\mathrm{Cd}$ in the particulate phase. Adsorption onto the cell surface (b) is likely a small fraction. Adsorption to inorganic mineral phases (c) may play a minor role in particulate cadmium fractionation.

\section{The interaction of cadmium and zinc and cellular uptake}

Little is known about the intracellular partitioning of $\mathrm{Cd}$ and $\mathrm{Zn}$ following uptake in surface waters (Figure 1.3a). The question remains as to what the organisms are doing with $\mathrm{Cd}$ and $\mathrm{Zn}$ once inside the cell. This question was actively pursued in cyanobacteria using physiological and proteomic studies in Chapters 3 and 4. Zinc is vital to many enzymes. Of all enzymes with known structures, $\mathrm{Zn}$ is utilized in $9 \%$ of them (Waldron et al., 2009). This is second only to magnesium (16\%) (Waldron et al., 2009). Cd, on the other hand, is only known in the structure of a single carbonic anhydrase (Xu et al., 2008). Some other possibilities for intracellular Cd include incorporation into calcium carbonate tests of foraminifera, binding by metallothionein, binding by low molecular weight thiols, sequestration in polyphosphates and possible use in other enzymes (Figure 1.4). Boyle 1976 posed the question to what part of the cell the $\mathrm{Cd}$ goes, either the soft part or the hard parts. The soft part is thought to dominate because the ratio of $\mathrm{Cd}: \mathrm{C}$ in organic matter is $3.3 \times 10^{-6}$ and $\mathrm{Cd}: \mathrm{C}$ in carbonate minerals is less than $0.2 \times 10^{-6}$ (Boyle, 1988). The carbonate phase, including foraminifera, is responsible for only $2 \%$ of 
vertical cadmium transport (Boyle, 1988). This is important for the use of $\mathrm{Cd}: \mathrm{Ca}$ as a paleoproxy for phosphate concentrations in foraminiferal calcite, through incorporation of Cd into foraminiferal tests (Boyle, 1988; Elderfield and Rickaby, 2000). Ho et al., 2003 did a study on the metal composition of fifteen marine eukaryotic plankton species. Their results corroborate that significant $\mathrm{Cd}$ may not be present in the hard parts. Cyanobacteria do not have hard parts, so Cd must be interacting with the cell, probably in the form of proteins or metabolites.

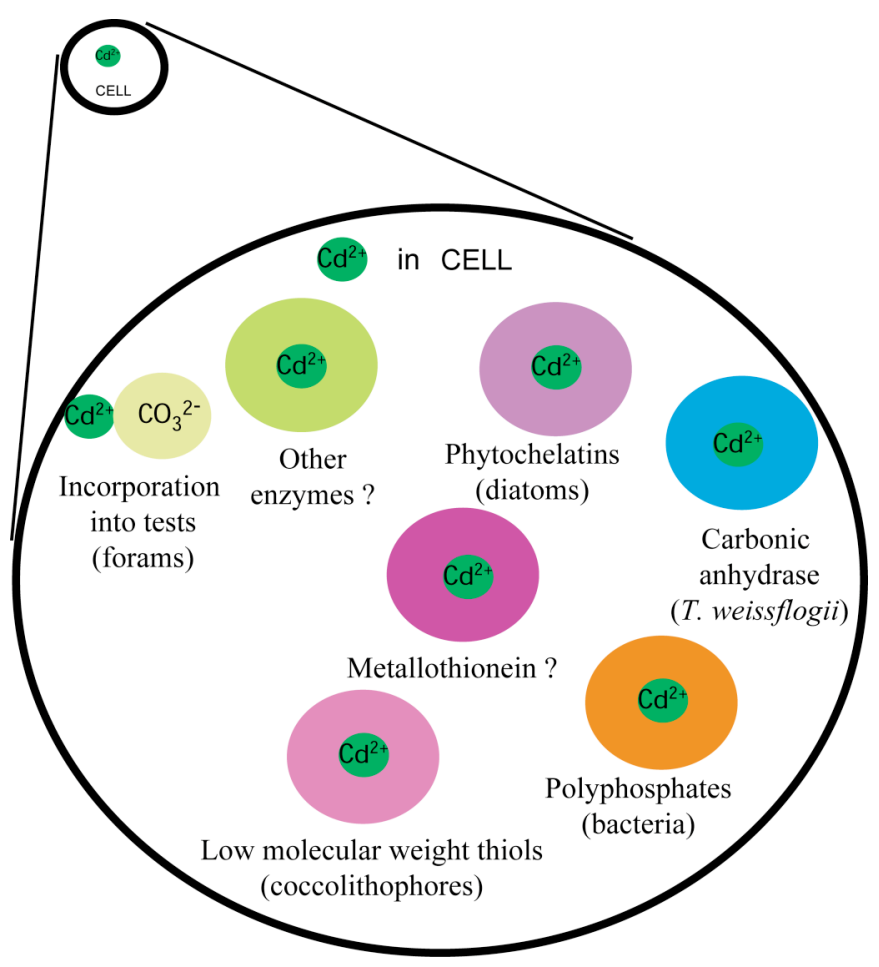

Figure 1.4: Cd inside a cell. The distribution of cadmium within the cell is unknown. Cd has been shown to replace $\mathrm{Zn}$ in the active site of carbonic anhydrase in the diatom, T. weissflogii. Incorporation into foraminiferal tests has been observed. Cd could possibly be used in other cellular enzymes.

The concept of $\mathrm{Cd}$ as a nutrient or a toxin has been investigated in cultures of cyanobacteria in Chapters 3 and 4. Cd has been shown to have toxic effects to eukaryotic organisms in culture (Lee and Morel, 1995), but in some instances of $\mathrm{Zn}$ limitation in the marine diatom Thalassiosira weissflogii and other species the addition of low levels of Cd restored the growth rate (Price and Morel, 1990; Lee and Morel, 1995; Sunda and Huntsman, 2000). It follows that $\mathrm{Cd}$ at low concentrations (pM) may act as a nutrient by 
replacing $\mathrm{Zn}$ (Lee and Morel, 1995), with Cd replacing $\mathrm{Zn}$ in the active site of carbonic anhydrase (Morel et al., 1994; Lee et al., 1995; Lane and Morel, 2000 and Lane et al., 2005). Early work on this concept showed that in certain fungi $\mathrm{Cd}$ cannot physiologically replace Zn (Goldschmidt, 1954). However, Synechococcus species have been shown to have lower toxicity thresholds relative to eukaryotic organisms by approximately two orders of magnitude (Brand et al., 1986; Payne and Price, 1999; Saito et al., 2003). Carbonic anhydrase may not be the major sink for cellular Cd, given that the only known biological use of $\mathrm{Cd}$ is as a substitute for $\mathrm{Zn}$ in a $\mathrm{Cd}$ carbonic anhydrase $(\mathrm{CdCA})$, and the gene for $\mathrm{CdCA}$ is not found in cyanobacterial genomes. A calculation and/or study demonstrating the fraction of cellular $\mathrm{Cd}$ in carbonic anhydrase has not been performed, although cadmium-containing carbonic anhydrases are a topic of active research (Lane et al., 2005; Park et al., 2007; Xu et al., 2008). The question of intracellular Cd partitioning is difficult to answer partially because the carbonic anhydrase content and subsequent Cd uptake of some cells has been suggested to change with $\mathrm{pCO}_{2}$ (Cullen et al., 1999) and it is difficult to measure. The presence of $\mathrm{Zn}$ has been previously noted to have an effect on Cd toxicity (Saito et al., 2003) and Chapters 3 and 4 address this issue.

There is another possibility for the localization of intracellular $\mathrm{Cd}$. Metallothionein, by binding metals, can act as an intracellular buffer (Figure 1.5). If the cell is not actively utilizing $\mathrm{Cd}$, then perhaps it is being stored somewhere where it cannot affect the overall functionality of the cell. Metallothioneins have been observed to form clusters in cells with bound metals in mammalian systems. Synthesis of metallothioneins has been shown to be induced by increased metal and oxidative stress (Palmiter, 1998 and references therein). 


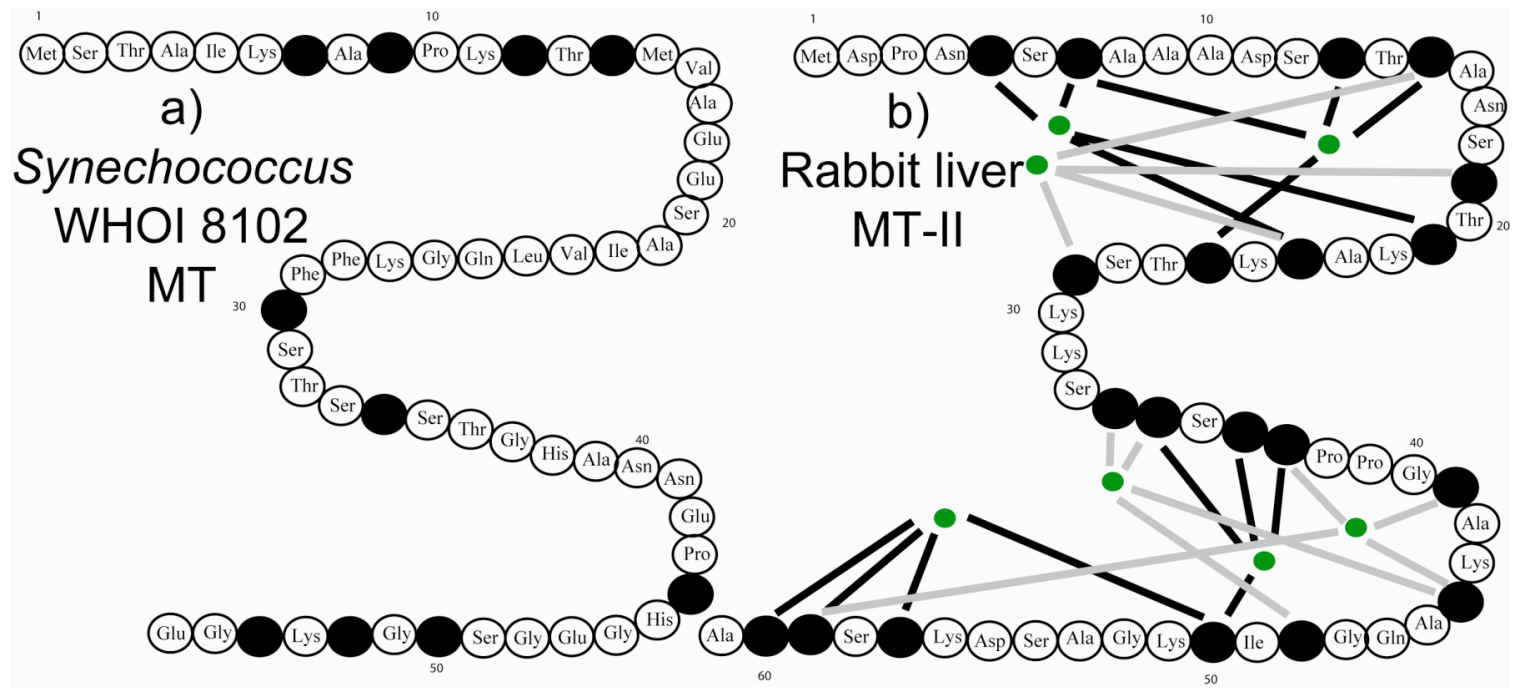

Figure 1.5: Metallothionein (MT) a) Metallothionein from the cyanobacterium, Synechococcus WH8102, 56 amino acid protein. b) MT-II from rabbit liver, 61 amino acid protein. MT-II binds seven $\mathrm{Cd}$ ions in two clusters. The number of metal ions bound and structure of metallothionein from WH8102 is unknown. Black depicts cysteine residues. Met $=$ methionine, Ser $=$ serine, Thr $=$ threonine, $\mathrm{Ala}=$ alanine, $\mathrm{Ile}=$ isoleucine, $\mathrm{Lys}=$ lysine, Pro $=$ proline, $\mathrm{Val}=$ valine, $\mathrm{Glu}=$ glutamic acid, Gly = glycine, Gln = glutamine, Phe = phenylalanine, His = histidine, Asn = asparagine, $\mathrm{Asp}=$ aspartic acid. Green spheres represent $\mathrm{Cd}^{2+}$ ions. Black and grey lines represent bonds from $\mathrm{Cd}^{2+}$ ions to cysteine residues.

Metallothioneins are found in organisms ranging from multicellular eukaryotes to bacteria and have been typically associated with the metals, zinc, copper, and cadmium, although they have also been observed to bind silver, mercury, and arsenic as well (Duncan et al., 2006). They belong to a super-family of intracellular metal-binding proteins (Coyle, 2002), although they have been reported extracellularly in eukaryotic organisms (Lynes, 2006). Metallothioneins are polypeptides that, based on equine renal metallothionein, have several of the following six features: 1) low molecular weight, approximately 56 amino acid residues, 2) high metal content, 3) a characteristic amino acid composition consisting of high cysteine content, and no aromatic amino acids (phenylalanine, tryptophan, and tyrosine) nor histidine, 4) unique amino acid sequence with a characteristic distribution of cysteine (cys) residues such as cys-X-cys, 5) spectroscopic features characteristic of metal thiolates (mercaptides), and 6) metal thiolate cluster (Kojima et al., 1999). Note that histidine has subsequently been found in 
bacterial metallothioneins and can enhance the relative affinity for $\mathrm{Zn}$ in comparison to Cd (Blindauer, 2008b).

The precise function of eukaryotic metallothionein has eluded researchers ever since it was first isolated and identified in 1957 from horse kidney (Margoshes and Vallee, 1957). Metallothioneins may function as 1) metal resistance proteins for detoxifying zinc, cadmium, and copper; 2) reservoirs for the storage of excess $\mathrm{Zn}$ and/or copper that can be mobilized under metal limiting conditions; 3) metal chaperones that deliver $\mathrm{Zn}$ to $\mathrm{Zn}$-dependent proteins; and 4) antioxidants that scavenge oxygen radicals (Palmiter, 1998). Bacterial metallothioneins have thus far been implicated in the cellular homeostasis of $\mathrm{Zn}$ through the binding, sequestering, and buffering of intracellular $\mathrm{Zn}$ (Robinson et al., 2001). In mammals, metallothioneins are thought to protect cells from oxidative damage (Cai and Cherian, 2003). Kang (2006) maintains that the redox cycle of metallothionein supports the use of metallothioneins in cell homeostasis, protection from oxidative stress, and metal detoxification. The role of metal detoxification has the most supporting evidence, although there also has been increasing evidence for the paramountcy of metallothionein to maintaining intracellular homeostasis of $\mathrm{Zn}$ and $\mathrm{Cu}$, particularly the metal storage and chaperone roles of metallothionein (Suhy et al., 1999; Rae et al., 1999; O'Halloran and Culotta, 2000; and Outten and O'Halloran, 2001).

Turning to organisms relevant to the ocean and integral to global carbon cycling, metallothioneins have been found in the genomes of numerous Synechococcus strains, such as WH8102 (1), WH7803 (1), WH5701 (2), CC9311 (4) and CC9605 (3) (Palenik et al., 2003; Palenik et al., 2006). Protein database searches yield metallothionein proteins in eight Synechococcus species, three of them marine, two of them thermophiles, and none in Prochlorococcus species (twelve genomes searched). Amino acid alignments reveal on average $36 \%$ identity among these cyanobacterial metallothioneins. Palenik et al., 2003 suggest that Synechococcus seems to be more resistant to copper compared to Prochlorococcus and that the difference may be due to efflux pumps for metals present in Synechococcus that are not present in Prochlorococcus. Metallothionein may contribute to this difference. The role of metallothioneins and their relationship to metal 
concentrations in the environment has been largely unexplored. The work involved in this thesis explored the possibility of metallothioneins being important for $\mathrm{Zn}$ homeostasis and the prevention of $\mathrm{Cd}$ toxicity and some data are shown in Chapter 4.

Metallothioneins are not the only compounds known to bind metals in cells (Figure 1.6). Other known metal binding ligands include phytochelatins, which were first isolated from plants and later observed to occur in ocean waters (Ahner et al., 1994, 1997). Phytochelatins were classified as a MT-III (Shaw et al., 1992). For phytochelatins to maintain a concentration of $20 \mathrm{pM}$ in the water column they would need an extracellular turnover time of 100 days assuming an open ocean chlorophyll $a$ concentration of $0.1 \mu \mathrm{g} \mathrm{L}^{-1}$, a phytochelatin concentration of $2 \mu \mathrm{g}$ per g chl $a$, and a phytoplankton turnover of 1 day (Ahner et al., 1994). The authors concluded that phytochelatins do not constitute a major fraction of the elusive metal ligands dissolved in seawater measured by electrochemists, because the thiols are subject to oxidation and the overall molecule subject to proteases. Protein database searches yield a putative phytochelatin synthase in Prochlorococcus and a phytochelatin synthase-like protein in Synechococcus, although it is said that phytochelatins have been extensively searched for and not found in many species of cyanobacteria (James Moffett, personal communication, 2007). Phytochelatins are comprised of a repeating peptide sequence of $(\gamma \text {-Glu-Cys) })_{\mathrm{n}}$-Gly, where $\mathrm{n}=2-11$ (Figure 1.6c).

Glutathione is a tripeptide of Glu-Cys-Gly, and a possible metal binding agent (Figure 1.6b). Low molecular weight thiols such as glutathione have been studied in marine phytoplankton and in the ocean (Tang et al., 2000; Dupont and Ahner, 2005; Dupont et al., 2006a). They are thought to be important to metal speciation (Dupont and Moffett et al., 2006). The vital amino acid for metal affinity in all of these compounds is cysteine (Figure 1.6a). Particulate and dissolved total and reduced thiols were made in collaboration with Tristan Kading in a repeat experiment of the $\mathrm{Zn}$-deprived chronic $\mathrm{Cd}$ experiment discussed in Chapter 3, and the preliminary results show that these metabolites are an important response to Cd exposure in Synechococcus WH5701. 
Metallothionein is just one of several possible biomolecules to be involved in metal homeostasis, and the least studied in marine environments.

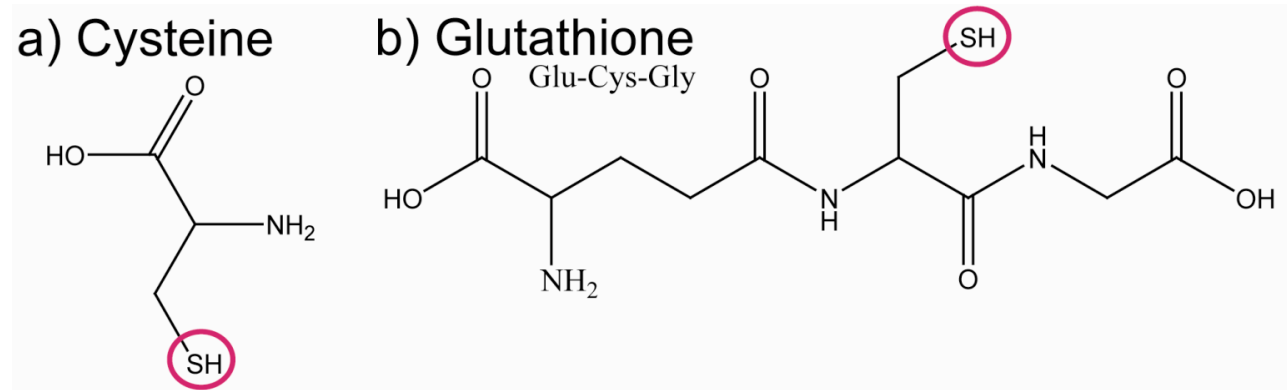

C) Phytochelatin (MT-III)
$(\gamma-\mathrm{Glu}-\mathrm{Cys})_{\mathrm{n}}-\mathrm{Gly} n=2-11$

Figure 1.6: Possible metal binding moieties in cells. a) the amino acid cysteine. b) glutathione. c) phytochelatin, classified as a MT-III.

In a recent EXAFS study of Cd binding to the surfaces of Bacillus subtilis and Shewanella oneidensis, sulfhydryl sites on the surface of cells may be important for environmental metal binding (Mishra et al., 2010). Loadings varied from 1-200 ppm and phosphoryl sites were more important than carboxyl ligands for $\mathrm{Cd}$ binding at high $\mathrm{Cd}$ loadings, carboxyl sites were important at intermediate Cd loadings and sulfhydryl sites were dominant at low Cd loadings (Mishra et al., 2010). These loadings are many orders of magnitude greater than any loadings one might expect in the marine environment, nevertheless, this is related evidence for the importance of sulfhydryl-metal binding.

\section{Interaction of zinc and phosphorus}

As $\mathrm{Zn}$ and $\mathrm{Cd}$ are known to interact, and $\mathrm{Cd}$ and phosphate are observed to be correlated in the ocean, so do $\mathrm{Zn}$ and $\mathrm{P}$ have an observed relationship. $\mathrm{Zn}$ and $\mathrm{P}$ are thought to be an example of Type III biochemically dependent colimitation, where the uptake of one nutrient, $\mathrm{P}$, is dependent upon adequate nutrition with regard to the other, $\mathrm{Zn}$ (Saito et al, 2008). Alkaline phosphatase may be at the root of this; it is in many cases a Zn-requiring enzyme (Morel et al., 2003) and is used to access organic phosphonates, 
often during times of low phosphate availability. Based on extrapolation of experimentation with the coccolithophore Emiliania huxleyi, $\mathrm{Zn}$ and $\mathrm{P}$ colimitation could occur in highly oligotrophic regions such as the Sargasso Sea (Shaked et al., 2006). The interactions of $\mathrm{Zn}$ and $\mathrm{P}$ are addressed in Chapter 4.

\section{Environmental Gradient Culture Studies}

During the course of this thesis work, five strains of marine Synechococcus WH5701, WH8109, WH7803, WH7805 and WH8102 with sequenced genomes (or sequencing in progress as in the case of WH8109) were used as representatives of organisms adapted to a varying natural oceanic chemical gradient due to their original isolation location from Long Island Sound (WH5701) out to the Sargasso Sea (WH8102) (Figure 1.7). The coastal side of the environmental gradient is expected to have higher trace metal availability and experience increased variability in irradiance due to mixing relative to the open ocean. Researchers have long been interested in the interaction and interdependence between microorganisms and their environmental milleux. Strains with genomic information were chosen so that proteomic analyses could be performed. All strains were maintained over the course of two-plus years in a modified EDTA-buffered PRO-TM media both with and without the addition of $\mathrm{Zn}$. Most of my experiments were done with the cultures maintained without $\mathrm{Zn}$ in the media. The physiological (in all cases) and proteomic responses (in some cases) to varying metal manipulations of cadmium, zinc, copper and iron as well as macronutrient manipulations with phosphate and nitrate were investigated in order to elucidate the interactions of these metals with each other and the respective strains of cyanobacteria. Two of these experiments are presented in Chapters 3 and 4. 


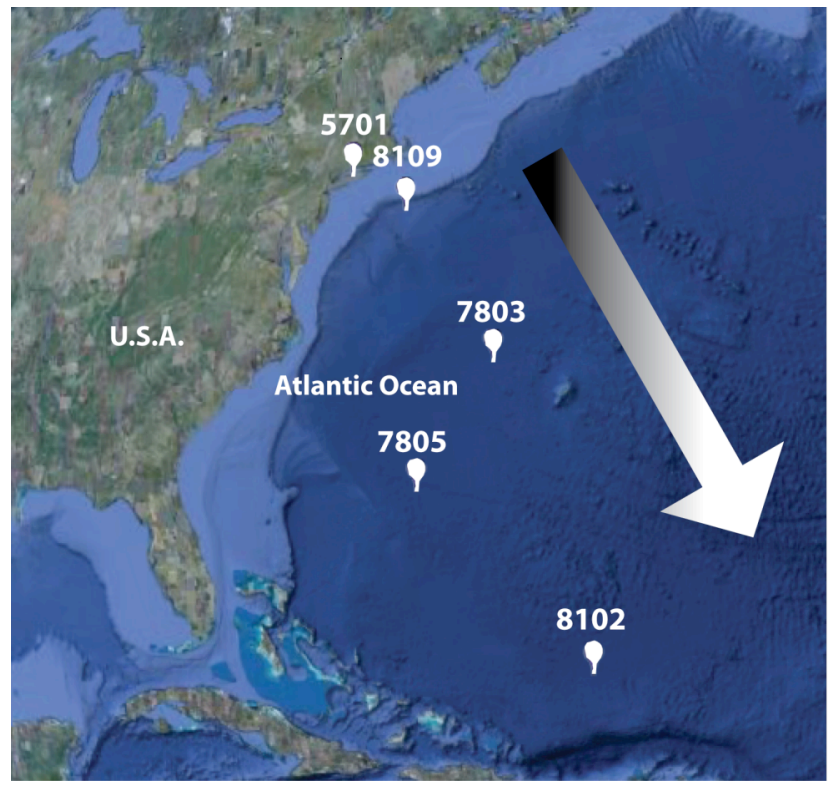

Figure 1.7: Original isolation locations of Synechococcus WH strains. Arrow symbolizes an environmental gradient.

At the beginning of the culture experimentation during this thesis work, the hypothesis was that the more coastally proximal strains would be better able to deal with $\mathrm{Cd}$ and $\mathrm{Zn}$ stress because of their origin, thus inheriting a greater genetic capability to deal with environmental stressors. The role of $\mathrm{Cd}$ as nutrient or toxin was queried under this hypothesis because of the fine line between toxin and nutrient that has been noted in the literature for this element, the oceanographic relationship observed between cadmium and phosphate, and the uptake of Cd observed in the field described in Chapter 2. Strains were deprived of $\mathrm{Zn}$ in order to find the limits of $\mathrm{Cd}$ toxicity, it was noted in earlier studies that the presence of Zn decreased the toxicity of Cd (Saito et al., 2003).

Preliminary studies (data not shown) led to the studies that are presented here in Chapters 3 and 4.

Metals and proteins in cells interact in many ways. Many proteins directly require metals as cofactors in order to properly function. In this thesis, the different exposures of cyanobacterial cells to $\mathrm{Cd}$ and $\mathrm{Zn}$ were shown to affect relative protein abundances and by inference the overall functionality of a cell. This global proteomics approach provides a relative quantification of changes in protein abundance between samples in a given experiment and may be considered systems biology. Examining these data may indicate potential mechanisms of action with regard to the effects of metals and macronutrients 
inside a cell and is the first level of investigation. The data sets produced in Chapters 3 and 4 provide some insights to potential mechanisms of metal homeostasis and toxicity in cyanobacterial cells, but inevitably provoke more questions providing an excellent base from which to launch future research, be it absolute quantification of proteins using the same samples using triple quadrupole mass spectrometry, detailed biochemical investigations, more culture studies, or interactions in the environment. In the future, as proteomic methods are applied to environmental samples and combined with particulate and dissolved metal and metabolite measurements as well as parallel laboratory investigations into mechanisms, perhaps the interactions of $\mathrm{Cd}, \mathrm{Zn}$ and $\mathrm{P}$ in the ocean will become clear. As for this thesis, it represents a first step into understanding $\mathrm{Cd}$ uptake in the ocean and the interactions of $\mathrm{Cd}, \mathrm{Zn}$, and $\mathrm{P}$ in marine cyanobacteria. 


\section{References}

Ahner, B.A., Price, N.M. and Morel, F.M.M. 1994. Phytochelatin production by marine phytoplankton at low free metal ion concentrations: laboratory studies and field data from Massachusetts Bay. PNAS 91: 8433-8436.

Ahner, B.A., Morel, F.M.M. and Moffett, J.W. 1997. Trace metal control of phytochelatin production in coastal waters. Limnology and Oceanography 42(3): 601608.

Anbar, A.D. and Knoll, A.H. 2002. Proterozoic ocean chemistry and evolution: a bioinorganic bridge? Science 297: 1137-1142.

Blindauer, C.A. 2008a. Zinc-handling in cyanobacteria: An Update. Chemistry and Biodiversity 5: 1990- 2013.

Blindauer, C.A. 2008b. Metallothioneins with unusual residues: Histidines as modulators of zinc affinity and reactivity. Journal of Inorganic Biochemistry 102: 507-521.

Brand, L.E., Sunda, W.G. and Guillard, R.R.L. 1986. Reduction of marine phytoplankton reproduction rates by copper and cadmium. Journal of Experimental Marine Biology and Ecology 96: 225-250.

Boyle, E.A., Sclater, F. and Edmond, J.M. 1976. On the marine geochemistry of cadmium. Nature 263: 42-44.

Boyle, E.A. 1988. Cadmium: chemical tracer of deepwater paleoceanography. Paleoceanography 3: 471-489.

Bruland, K. W. 1980. Oceanographic distributions of cadmium, zinc, nickel, and copper in the North Pacific. Earth and Planetary Science Letters 47: 176-198.

Bruland, K.W. 1992. Complexation of cadmium by natural organic ligands in the central North Pacific. Limnology and Oceanography 37(5): 1008-1017.

Cai, L. and Cherian, M.G. 2003. Zinc-metallothionein protects from DNA damage induced by radiation better than glutathione and copper- or cadmium metallothioneins. Toxicology Letters 136: 193-198.

Canfield, D.E. 1998. A new model for Proterozoic ocean chemistry. Nature 396: 450453.

Catling, D. C., Zahnle, K. J. and McKay, C.P. 2001. Biogenic methane, hydrogen escape, and the irreversible oxidation of early Earth. Science 293: 839-843. 
Catling, D.C. and Claire, M.W. 2005. How Earth's atmosphere evolved to an oxic state: a status report. Earth and Planetary Science Letters 237: 1-20.

Coyle, P., Philcox, J.C., Carey, L.C. and Rofe, A.M. 2002. Metallothionein: The multipurpose protein. Cellular and Molecular Life Sciences 59: 627-647.

Cullen, J.T., Field, M.P. and Sherrell, R.M. 2001. Determination of trace elements in filtered suspended marine particulate material by sector field HR-ICP-MS. Journal of Analytical Atomic Spectrometry 16 (11): 1307-1312.

Cullen, J. T., Lane, T. W., Morel, F. M. M. and Sherrell, R. M. 1999. Modulation of cadmium utilization in phytoplankton by seawater concentration. Nature 402: 165-167.

Cullen, J.T. and Sherrell, R.M. 1999. Techniques for determination of trace metals in small samples of size-fractioned particulate matter: phytoplankton metals off central California. Marine Chemistry 67: 233-247.

Duncan, K.E.R., Ngu, T.T., Chan, J., Salgado, M.T., Merrifield, M.E. and Stillman, M.J. 2006. Peptide folding, metal-binding mechanisms, and binding site structures in metallothioneins. Experimental Biology and Medicine 231: 1488-1499.

Dupont, C.L. and Ahner, B. 2005. Effects of copper, cadmium, and zinc on the production and exudation of thiols by Emiliania huxleyi. Limnology and Oceanography 50(2): 508-515.

Dupont, C.L., Moffett, J.W., Bidigare, R.R. and Ahner, B.A. 2006a. Distributions of dissolved and particulate biogenic thiols in the subartic Pacific Ocean. Deep Sea Research Part I: Oceanographic Research Papers 53(12): 1961-1974.

Dupont, C.L., Yang S., Palenik B., and Bourne, P.E. 2006b. Modern proteomes contain putative imprints of ancient shifts in trace metal geochemistry. Proceedings of the National Academy of Sciences 103 (47): 17822-17827.

Elderfield, H. and Rickaby, R.E.M. 2000. Oceanic Cd/P ratio and nutrient utilization in the glacial Southern Ocean. Nature 405: 305-310.

Ellwood, M.J. and Van den Berg, C.M.G. 2000. Zinc speciation in the Northeastern Atlantic Ocean. Marine Chemistry 68: 295-306.

Ellwood, M.J. 2004. Zinc and cadmium speciation in subantarctic waters east of New Zealand. Marine Chemistry 87: 37-58. 
Falkowski, P. G. 1994. The role of phytoplankton photosynthesis in global biogeochemical cycles. Photosynthesis Research 39 (3): 235-258.

Field, C.B., Behrenfeld, M.J., Randerson, J.T. and Falkowski P. 1998. Primary production of the biosphere: Integrating terrestrial and oceanic components. Science 281: 237-240.

Glazer, A. N. 1989. Directional energy transfer in a photosynthetic antenna. The Journal of Biological Chemistry 264: 1-4.

Goldschmidt, V.M. 1954. edited by Alex Muir. Geochemistry. Oxford at Clarendon Press.

Ho, T.Y., Quigg, A., Finkel, Z.V., Milligan, A.J., Wyman, K., Falkowski, P.G., and Morel, F.M.M. 2003. The elemental composition of some marine phytoplankton. Journal of Phycology 39: 1145-1159.

Hoiczyk, E. and Hansel, A. 2000. Cyanobacterial cell walls: News from an unusual prokaryotic envelope. Journal of Bacteriology 182(5): 1191-1199.

Hudson, R.J.M. and Morel, F.M.M. 1989. Distinguishing between extra- and intracellular iron uptake in marine phytoplankton. Limnology and Oceanography 34: 1113-1120.

Hunter, K.A., Kim, J.P., and Croot, P.L.1997. Biological roles of trace metals in natural waters. Environmental Monitoring and Assessment 44: 103-147.

Hutchins, D.A., Witter, A. E., Butler, A. and Luther, G.W. 1999. Competition among marine phytoplankton for different chelated iron species. Nature 400: 858-861.

Kang, Y.J. 2006. Metallothionein redox cycle and function. Experimental Biology and Medicine 231: 1459-1467.

Kojima, Y., Binz, P.A., and Kaegi J.H.R. 1999. Nomenclature of metallothionein: Proposal for a revision. In Metallothionein IV ed. Klaassen, C. pgs. 3-5.

Kresage, N., Simoni, R.D., Hill, R. L. 2009. Phycobilisome architecture: the work of Alexander N. Glazer. The Journal of Biological Chemistry 284 (36): e12-e14.

Lane, E.S., Semeniuk, D. M., Strzepek, R. F., Cullen, J.T. and Maldonado, M. T. 2009. Effects of iron limitation on intracellular cadmium of cultured phytoplankton:

Implications for surface dissolved cadmium to phosphate ratios. Marine Chemistry 115: 55-162. 
Lane, T.W. and Morel, F.M.M. 2000. A biological function for cadmium in marine diatoms. Proceedings of the National Academy of Sciences 97: 4627-4631.

Lane, T.W., Saito, M.A., George, G.N., Pickering, I.J. and Prince, R.C. 2005. A cadmium enzyme from a marine diatom. Nature 435: 42.

Lee, J.G. and Morel, F.M.M. 1995. Replacement of zinc by cadmium in marine phytoplankton. Marine Ecology Progress Series 127: 305-309.

Lee, JG., Roberts, S.B. and Morel, F.M.M. 1995. Cadmium: a nutrient for the marine diatom Thalassioria weissflogii. Limnology and Oceanography 40: 1056-1063.

Lynes, M.A., Zaffuto K., Unfricht, D.W., Marusov, G., Samson, J.S. and Yin, X. 2006. The physiological roles of extracellular metallothionein. Experimental Biology and Medicine 231: 1548-1554.

Maldonado, M. T. and Price, N. M. 1999. Utilization of iron bound to strong organic ligands by plankton communities in the subarctic Pacific Ocean. Deep Sea Research Part II 46: 2447-2473.

Marchant, R., Banat, I. M., Rahman, T. J. S. and Berzano, M. 2002. What are hightemperature bacteria doing in cold environments? Trends in Microbiology 10(3): 120121.

Margoshes, M. and Vallee, B.L. 1957. A cadmium protein from equine kidney cortex. Journal of the American Chemical Society 79: 4813-4814.

Mishra, B., Boyanov, M.I., Bunker, B. A., Kelly, S.D., Kemner, K.M., Nerenberg, R., Read-Daily, B.L. and Fein, J.B. 2009. An X-ray absorption spectroscopy study of Cd binding onto bacterial consortia. Geochimica et Cosmochimica Acta 73 (15): 4311-4325.

Morel, F.M.M., Milligan, A.J. and Saito, M.A. 2003. Marine bioinorganic chemistry: The role of trace metals in the oceanic cycles of major nutrients. Treatise on Geochemistry Volume 6 The Oceans and Marine Geochemistry. eds. Henry Elderfield. H.D. Holland and K.K. Turekian. 6.05: 113-143.

Noddack, I. and Noddack, W. 1939. Die Häufigkeiten der Schwermetalle in Meerestieren. Arkiv för zoology 32A(4) Stockholm: Almqvist \& Wiksell.

O'Halloran, T.V., and Culotta, V.C. 2000. Metallochaperones, an intracellular shuttle service for metal ions. The Journal of Biological Chemistry 275(33): 25057-25060.

Outten, C.E. and O'Halloran, T.V. 2001. Femtomolar sensitivity of metalloregulatory proteins controlling zinc homeostasis. Science 292: 2488-2492. 
Palenik, B., Ren, Q., Dupont, C.L., Myers, G.S., Heidelberg, J.F., Badger, J.H., Madupu, R., Nelson, W.C., Brinkac, L.M., Dodson, R.J., Durkin, A.S., Daugherty, S.C., Sullivan, S.A., Khouri, H., Mohamoud, Y., Halpin, R., Paulsen, I.T. 2006. Genome sequence of Synechococcus CC9311: Insights into adaptation to a coastal environment. PNAS: 103(36): 13555-13559.

Palenik, B., Brahamsha, B., Larimer, F.W., Land, M., Hauser, L., Chain, P., Lamerdin, J., Regala, W., Allen, E.E., McCarren, J., Paulsen, I., Dufresne, A., Partensky, F., Webb, E.A., and Waterbury, J. 2003. The genome of a motile marine Synechococcus. Nature 424: 1037-1042.

Palmiter, R.D. 1998. The elusive function of metallothioneins. PNAS 95: 8428-8430.

Park, H., Song, B. and Morel, F. M. M. 2007. Diversity of the cadmium-containing carbonic anhydrase in marine diatoms and natural waters. Environmental Microbiology 9(2): 403-413.

Payne, C.D. and Price, N.M 1999. Effects of cadmium toxicity on growth and elemental composition of marine phytoplankton. Journal of Phycology 35: 293-302.

Price, N.M. and Morel, F.M.M. 1990. Cadmium and cobalt substitution for zinc in a marine diatom. Nature 344: 658-660.

Quigg, A., Reinfelder, J. R. and Fisher, N.S. 2006. Copper uptake kinetics in diverse marine phytoplankton. Limnology and Oceanography 51: 893-899.

Rae, T.D., Schmidt, P.J., Pufahl, R.A., Culotta, V.C. and O’Halloran, T.V.1999. Undetectable intracellular free copper: the requirement of a copper chaperone for superoxide dismutase. Science 284: 805-808.

Robinson, N. J., Whitehall, S.K., and Cavet, J.S. 2001. Microbial metallothioneins. Advances in Microbial Physiology 44: 183-213.

Rocap, G., Distel, D.L., Waterbury, J.B., and Chisholm, S.W. 2002. Resolution of Prochlorococcus and Synechococcus ecotypes by using 16S-23S ribosomal DNA internal transcribed spacer sequences. Applied and Environmental Microbiology 68(3): 11801191.

Saito, M.A., Sigman, D.M. and Morel, F.M.M. 2003. The bioinorganic chemistry of the ancient ocean: the co-evolution of cyanobacterial metal requirements and biogeochemical cycles at the Archean-Proterozoic boundary? Inorganica Chimica Acta 356: 308-318. 
Saito, M.A, Goepfert, T.J. and Ritt, J. 2008. Some thoughts on the concept of colimitation: Three definitions and the importance of bioavailability. Limnology and Oceanography 53(1): 276-290.

Saito, M. A., Goepfert, T. J., Noble, A. E., Bertrand, E. M., Sedwick, P. N. and DiTullio, G. R. 2010. A seasonal study of dissolved cobalt in the Ross Sea, Antarctica: micronutrient behavior, absence of scavenging, and relationships with $\mathrm{Zn}, \mathrm{Cd}$, and $\mathrm{P}$. Biogeosciences 7: 4059-4082.

Semeniuk, D.M., Cullen, J.T., Johnson, W.K., Gagnon, K., Ruth, T.J. and Maldonado, M.T., 2009. Plankton copper requirements and uptake in the subarctic Northeast Pacific Ocean. Deep Sea Research I 56: 1130-1142.

Shaked, Y., Xu, K., Leblanc, K. and Morel, F. M. M. 2006. Zinc availability and alkaline phosphatase activity in Emiliania huxleyi: Implications for Zn-P co-limitation in the ocean. Limnology and Oceanography 51: 299-309.

Shaw, C.F. III., Stillman, M.J. and Suzuki, K.T. Metallothioneins: An overview of metalthiolate complex formation in metallothioneins. In Stillman, M.J., Shaw, C.F. III., and Suzuki, K.T. (eds.) 1992. Metallothioneins. VCH Publishers 1-13.

Sherrell, R.M. and Boyle, E. A. 1992. The trace metal composition of suspended particles in the oceanic water column near Bermuda. Earth and Planetary Science Letters 111: $155-174$.

Scanlan, D.J. 2003. Physiological diversity and niche adaptation in marine Synechococcus. Advances in Microbial Physiology 47: 1-64.

Sorby, H.C. 1877. On the characteristic colouring-matters of the red groups of algae. Journal of the Linnean Society of London: Botany 15: 34-40.

Suhy, D.A., Simom, K.D., Linzert, D.I.H. and O'Halloran, T.V. 1999. Metallothionein is part of a zinc-scavenging mechanism for cell survival under conditions of extreme deprivation. The Journal of Biological Chemistry 274(14): 9183-9192.

Sunda, W.G. 1988. Trace metal interactions with marine phytoplankton. Biology and Oceanography 6: 411-442.

Sunda, W.G. and Huntsman, S.A. 2000. Effect of Zn, Mn, and Fe on Cd accumulation in phytoplankton: Implications for oceanic Cd cycling. Limnology and Oceanography 45(7): 1501-1516. 
Tang, D., Hung, C., Warnken, K. W. and Santschi, P. H. 2000. The distribution of biogenic thiols in surface waters of Galveston Bay. Limnology and Oceanography 45(6): 1289-1297.

Tang, D. and Morel, F.M.M. 2006. Distinguishing between cellular and Fe-oxideassociated trace elements in phytoplankton. Marine Chemistry 98(1): 18-30.

Tovar-Sanchez, A., Sañudo-Wilhelmy, S.A., Garcia-Vargas, M. Weaver, R.S., Popels, L.C. and Hutchins, D.A. 2003. A trace metal clean reagent to remove surface-bound iron from marine phytoplankton. Marine Chemistry 82: 91-99.

Tovar-Sanchez, A., Sañudo-Wilhelmy, S.A., Garcia-Vargas, M., Weaver, R.S., Popels, L.C. and Hutchins, D.A. 2004. Corrigendum to "A trace metal clean reagent to remove surface-bound iron from marine phytoplankton". [Marine Chemistry 82 (2003) 91-99] Marine Chemistry 85: 191.

Williams, R. J. P. 2007. Systems biology of evolution: the involvement of metal ions. Biometals 20: 107-112.

Williams, R. J. P. and Frausto da Silva, J.J.R. 2006. The Chemistry of Evolution: The Development of our Ecosystem. Elsevier.

Xu, Y., Feng, L., Jeffrey, P. D., Shi, Y. and Morel, F. M. M. 2008. Structure and metal exchange in the cadmium carbonic anhydrase of marine diatoms. Nature 452: 56-61.

Zwirglmaier, K., Heywood, J. L., Chamberlain, K., Woodward, E. M., Zubkov, M. V. and Scanlan, D. J. 2007. Basin-scale distribution patterns of picocyanobacterial lineages in the Atlantic Ocean. Environmental Microbiology 9(5): 1278-90. 


\title{
Chapter 2
}

\section{Enriched Stable Isotope Uptake and Cadmium Addition Experiments with Natural Picophytoplankton Assemblages in the Costa Rica Upwelling Dome}

\begin{abstract}
Cadmium $(\mathrm{Cd})$ can function as either a nutrient or toxin in the marine environment. This duality has been demonstrated in phytoplankton cultures where $\mathrm{Cd}$ has been shown to have toxic effects to cyanobacteria, but acts as a nutrient in the marine diatom Thalassiosira weissflogii by biochemically replacing zinc $(\mathrm{Zn})$. Whether or not $\mathrm{Cd}$ functions as a nutrient or toxin is likely to be controlled by its bioavailability to organisms, detoxification mechanisms the organisms may possess that give a toxicity threshold or sensitivity, and exposure or dosage. Like many other trace metals in surface waters, $\mathrm{Cd}$ is complexed by strong organic ligands, which are thought to be produced by marine phytoplankton, particularly the cyanobacteria, Synechococcus.

In the summer of 2005, the bioavailability and uptake of $\mathrm{Cd}$ in the Costa Rica Upwelling Dome was examined using Cd addition and enriched stable isotope uptake experiments. The Costa Rica Dome is a tropical thermocline dome in the Eastern Pacific fed uniquely by a coastal wind jet that produces a habitat with high phytoplankton biomass relative to surrounding waters. This dome supports some of the highest cell densities of the cyanobacterium, Synechococcus, reported in nature, making it an ideal place to observe microbial processes that may be affected by the higher abundance of Synechococcus. The greater hypothesis was that greater ligand production inside the dome might prevent $\mathrm{Cd}$ toxicity, but as a first step in this manuscript we tested whether or not communities inside the dome were less vulnerable to $\mathrm{Cd}$ toxicity than those outside the dome.

Higher quantities of biomass, higher toxicity thresholds of the microbial communities, and perhaps greater ligand production inside the dome, may prevent toxicity to upwelled $\mathrm{Cd}$ in this region, relative to the oligotrophic waters. Bottle incubation experiments with $\mathrm{Cd}$ additions ranging from 0.5 to $5 \mathrm{nM}$ resulted in reduced chlorophyll $a$ outside of the dome relative to control treatments, but showed no reduction in chlorophyll $a$ inside the dome, consistent with this hypothesis. Moreover, tracer uptake experiments were conducted with the intermediate-abundance stable isotope ${ }^{110} \mathrm{Cd}$ at stations within and without the dome, in which variations with depth and time were examined. Cd totals were measured shipboard and in the lab using anodic stripping voltammetry, showing depletion of total $\mathrm{Cd}$ in the surface waters and increased concentrations with depth. Cd uptake was greatest within the upper $40 \mathrm{~m}$ of water inside the dome, decreased with depth and increased with time. Uptake correlated positively with chlorophyll $a$ concentrations. Together, these experiments suggest uptake of Cd into the microbial loop in the upper water column both in and out of the Costa Rica Dome, but show that Cd toxicity was not induced within the dome (presumably due to a higher amount of biomass in that region) and that perhaps Synechococcus has a lower sensitivity to $\mathrm{Cd}$ relative to Prochlorococcus outside of the dome.
\end{abstract}




\section{INTRODUCTION}

\section{Phytoplankton and Cadmium in the Marine Environment}

Marine phytoplankton are important contributors to primary productivity and have been a vital part of the ecosystem for billions of years (see page 11 in Chapter 1 for a more detailed discussion). Cadmium (Cd) is biogeochemical enigma, toxic but with a nutrient-like distribution in the ocean, implying biological uptake and regeneration at depth. The details of the relationship between marine phytoplankton and $\mathrm{Cd}$ are still not well understood.

$\mathrm{Cd}$ is a trace metal with concentrations ranging from 1 to $1,100 \mathrm{pM}$ in the open ocean (Bruland, 1980). Cd profiles are nutrient-like, resembling phosphorus profiles; concentrations are depleted in surface waters, increase with depth, and are fairly constant in deep waters (Boyle et al., 1976; Bruland, 1980; Boyle, 1988). The 'kink' noticed in plots of dissolved $\mathrm{Cd}: \mathrm{PO}_{4}{ }^{3-}$ ratios has been the topic of much discussion in the literature. Some conclude it is an artifact of fitting straight lines to seawater data caused by preferential extraction of $\mathrm{Cd}$ relative to $\mathrm{P}$ in those waters, without providing a mechanism (Elderfield and Rickaby, 2000). One mechanism is a slightly deeper regeneration cycle for Cd than for P (Boyle, 1988). Others propose that the injection of Cd-depleted high latitude Southern Ocean waters into intermediate depths of the global ocean may be the mechanism (Frew and Hunter, 1992). Further Southern Ocean data drew these authors to add formation of high-Cd Antarctic bottom waters near the Antarctic continent and remineralization of low-Cd-P detritus from biota produced in waters formed at the subtropical convergence as two additional mechanisms (Frew and Hunter, 1995). Others have proposed that the low $\mathrm{Cd}$ : $\mathrm{PO}_{4}{ }^{3-}$ ratios in the iron-depleted waters of the Southern Ocean and subarctic Pacific are caused by high levels of $\mathrm{Zn}$ depletion, which induce high levels of Cd uptake by phytoplankton (Sunda and Huntsman, 2000). Yet others have proposed the preferential removal of $\mathrm{Cd}$ relative to $\mathrm{PO}_{4}{ }^{3-}$ in Fe-limited waters is the result of chronic Fe limitation reducing phytoplankton growth rates relative to non-Fe limited phytoplankton, while not affecting Cd uptake rates, thereby causing the kink (Cullen, 2006; Lane et al., 2009). 
Like most other trace metals in surface waters, $\mathrm{Cd}$ is complexed by strong organic ligands as mentioned in Chapter 1 (Bruland, 1980; Bruland, 1992; Morel et al., 2003; Ellwood, 2004). The speciation of $\mathrm{Cd}$ and other trace metals determines their bioavailability (Hunter et al., 1997). Bioavailability refers to the ability of a substance to be taken up into a cell. If a molecule is not bioavailable then it cannot act as either a nutrient or a toxin. Due to the dissociation of trace-metal complexes, however, bioavailability may ultimately become a kinetic concept as discussed by Morel et al. (2003).

For a detailed discussion of the toxic effects of $\mathrm{Cd}$ to organisms in culture, relationship to $\mathrm{Zn}$ and a nutritive use of cadmium in a carbonic anhydrase of a eukaryotic diatom see pages 19-20 in Chapter 1. In work studying toxicity of copper to cyanobacteria, Prochlorococcus were inhibited at free $\mathrm{Cu}^{2+}$ that did not affect Synechococcus, although high-light adapted Prochlorococcus were more copper resistant than low-light adapted Prochlorococcus (Mann et al., 2002). In addition, Prochlorococcus has less genes annotated that cope with metal stress than Synechococcus, including less metal efflux pumps (Palenik et al., 2003) and no genes for metallothionein.

\section{The Costa Rica Upwelling Dome}

The Costa Rica Upwelling dome is a tropical thermocline dome located near $9^{\circ} \mathrm{N}$ $90^{\circ} \mathrm{W}$, with a diameter ranging from 100 to $1000 \mathrm{~km}$. Uniquely fed by a coastal wind jet, it is seasonably predictable, characterized by a shoaling of the thermocline by local cyclonic wind stress curl off of the coast during February and March. It separates from the coast during May-June and expands to the west during July-November. The dome produces a habitat with high phytoplankton and zooplankton biomass relative to that of surrounding tropical waters (Fiedler, 2002) (Figure 2.1). Interest in the dome began with observation of the physical oceanography by Wyrtki 1964, nutrient distributions by Broenkow in 1965, wind generation of the dome by Hofmann et al. 1981, and turned to the consideration of autotrophic picoplankton by Li et al. 1983. The increased primary productivity, biological effects, and phytoplankton assemblages of this feature continue 
to intrigue scientists (Fiedler, 2002; Franck et al., 2003; Saito et al., 2005). The highest cell reported cell densities of Synechococcus have been recorded in the dome, varying from $1.2 \times 10^{6}$ and $3.7 \times 10^{6}$ cells $\mathrm{mL}^{-1}$ (Saito et al., 2005). These high cell densities make the dome an ideal place to observe microbial community processes dominated by Synechococcus.

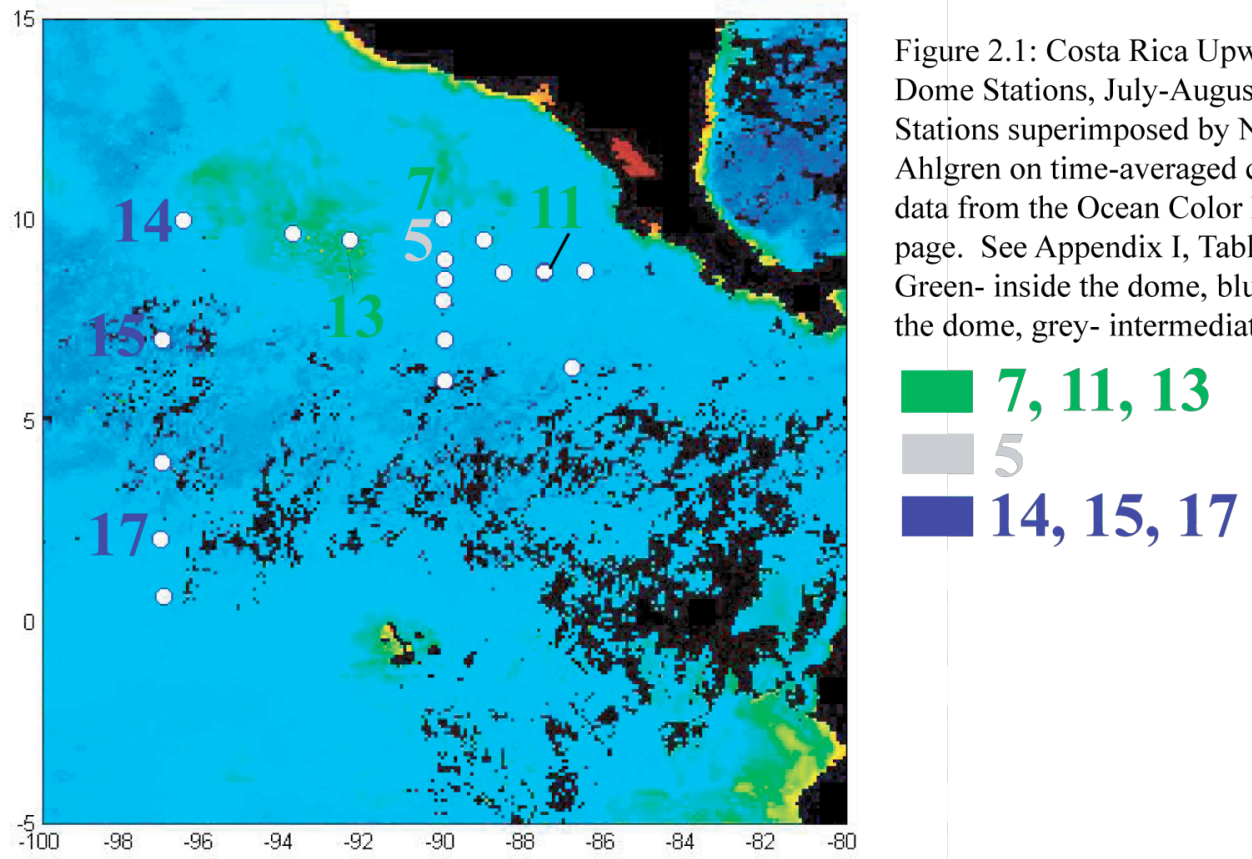

\section{${ }^{110}$ Cd Enriched Stable Isotopes and Incubation Techniques to Examine Bioavailability}

The eight stable isotopes of $\mathrm{Cd}$ range in natural abundance from $0.89\left({ }^{108} \mathrm{Cd}\right)$ to $28.73 \%\left({ }^{114} \mathrm{Cd}\right.$ ) (Figure 2.2). In this study, ${ }^{110} \mathrm{Cd}$, with a natural abundance of $12.49 \%$, was used as a tracer of $\mathrm{Cd}$ uptake into the particulate fraction $(>0.2 \mu \mathrm{m}) .{ }^{110} \mathrm{Cd}$ can be traced by an increase in concentration and deviation of samples from natural isotope abundance ratios (Table 2.1). Previously, uptake experiments have involved radiotracers such as ${ }^{65} \mathrm{Zn},{ }^{55} \mathrm{Fe},{ }^{59} \mathrm{Fe}$ or ${ }^{109} \mathrm{Cd}$ (Morel et al., 1994; Sunda and Huntsman, 1995; Cullen et al., 1999; Hutchins et al., 1999). Recently, low abundance stable isotopes of other elements have been used as tracers to study processes such as adsorption/desorption of particulate $\mathrm{Cu}, \mathrm{Zn}$, and $\mathrm{Ni}$ in estuaries (Gee and Bruland, 2002), bioaccumulation of $\mathrm{Hg}$ 
in lakes (Pickhardt et al., 2002), exchange of Fe and $\mathrm{Zn}$ between soluble, colloidal, and particulate size-fractions in shelf waters (Hurst and Bruland, 2007), and $\mathrm{Cd}$ and $\mathrm{Cu}$ uptake in a freshwater snail (Croteau and Luoma, 2007). Using stable isotopes over radiotracers affords many advantages including increased safety, ease of shipboard use clearance, and relatively felicitous waste disposal. This is the first reported study to use stable isotopes of $\mathrm{Cd}$ as a tracer of uptake in oceanic environments.

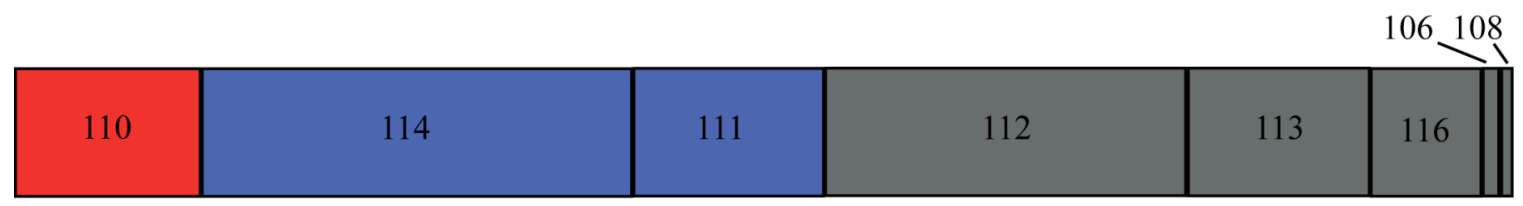

Figure 2.2: Relative abundances of stable cadmium isotopes. Red $-{ }^{110} \mathrm{Cd}$, tracer in this study. Blue $-{ }^{111} \mathrm{Cd}$ and ${ }^{114} \mathrm{Cd}$, measured isotopes in this study. Grey - other cadmium isotopes. Based on IUPAC values.

Table 2.1: Cadmium natural isotope abundance and isotope ratios

Isotope IUPAC value

$\begin{array}{ll}{ }^{106} \mathrm{Cd} & 0.0125(6) \\ { }^{108} \mathrm{Cd} & 0.0089(3) \\ { }^{110} \mathrm{Cd} & 0.1249(18) \\ { }^{111} \mathrm{Cd} & 0.1280(12) \\ { }^{112} \mathrm{Cd} & 0.2413(21) \\ { }^{113} \mathrm{Cd} & 0.1222(12) \\ { }^{114} \mathrm{Cd} & 0.2873(42) \\ { }^{116} \mathrm{Cd} & 0.0749(18)\end{array}$

Isotope ratios

${ }^{114} \mathrm{Cd} /{ }^{110} \mathrm{Cd} \quad 2.300$

${ }^{114} \mathrm{Cd} /{ }^{111} \mathrm{Cd} \quad 2.245$

${ }^{111} \mathrm{Cd} /{ }^{110} \mathrm{Cd} \quad 1.025$

Natural cadmium isotope abundances and ratios of the three isotopes measured in this study, based on IUPAC values. See Figure 2.2.

One goal of this study was to demonstrate that ${ }^{110} \mathrm{Cd}$ can be used to trace the movement of dissolved ${ }^{110} \mathrm{Cd}^{2+}$ to the particulate phase. Ideally, this transfer would represent biological uptake of bioavailable $\mathrm{Cd}$. There are limitations in terms of 
measuring biological uptake of $\mathrm{Cd}$ into cells. One must consider the definition of uptake and what it means to measure uptake in an environmental sample. The word "uptake" refers to the act of absorption, more specifically in biological terms, into a living organism. From the present field study, no distinction can be made between i) $\mathrm{Cd}$ absorption into cells, ii) Cd adsorption to the surface of cells, iii) $\mathrm{Cd}$ adsorption to nonliving particulate organic matter, and iv) $\mathrm{Cd}$ adsorption to particulate inorganic matter. In this study, the word "uptake" refers to the absorption of dissolved Cd into the particulate fraction, presumably into the cells of the phytoplankton community (i). Biological uptake (i) is likely to dominate the signal (due to the abundance of actively growing autotrophic cells in the photic zone); however, the methods of this study do not allow for the distinction between these four options. One disadvantage of this method is that if the cells are $\mathrm{Zn}$ or $\mathrm{Cd}$ limited, the addition may stimulate growth. To our knowledge, $\mathrm{Cd}$ limitation has never been shown in any organism. It is also notoriously difficult to limit cyanobacteria for $\mathrm{Zn}$, although it can be easily achieved with diatoms. Another goal of this study is to show that one 24-hr timepoint can be adequately used to measure Cd uptake as opposed to a time course or shorter-term experiment. Because casts at sea can occur around the clock, uptake rates may be affected by whether or not it is daylight when the incubation starts. In the microbial community different microorganisms may be actively taking up molecules at different points in a diel cycle. Allowing the sample to incubate with $\mathrm{Cd}$ over one diel cycle removes some of the concern of differential uptake due to time of day.

The disparity in toxicity thresholds between eukaryotic diatoms and among cyanobacteria, the reported nutritive use of $\mathrm{Cd}$ in a eukaryotic marine carbonic anhydrase, and the reports of organic ligands being produced in the Costa Rica Dome microbial community led to the investigation of $\mathrm{Cd}$ toxicity to natural phytoplankton assemblages. This location allowed a comparison between communities dominated by Synechococcus and Prochlorococcus. Observed toxicity to $\mathrm{Cd}$ treatments suggests that added $\mathrm{Cd}$ is bioavailable and entering cells, whereas no toxic effects suggest that added 
$\mathrm{Cd}$ is either perhaps less bioavailable, that is bioavailable yet taken up and detoxified, or that the same dosage affected different subsets of the microbial community differently.

Bioavailable refers to the ability of a chemical species to be absorbed into a cell and can be thought of as a spectrum ranging from more to less bioavailable. Some chemical species may be more bioavailable; for example, inorganic $\mathrm{Cd}$ may be more bioavailable than organically complexed $\mathrm{Cd}$, although the bioavailability of organically complexed $\mathrm{Cd}$ is not known. In addition, the dissociation of trace-metal complexes over time can affect bioavailability (Morel et al., 2003). Also, different chemical species can be more or less bioavailable to different microorganisms. As mentioned in Chapter 1, toxic effects in culture have been observed to be proportional to the summation of inorganic species (Sunda, 1988), although for copper and iron, organic ligands have been shown to be bioavailable (Hutchins et al., 1999; Maldonado et al., 1999; Quigg et al., 2006 and Semeniuk et al., 2009).

Toxicity is another biological term with a plurality of meanings. Toxicity can be considered the deleterious effects of a substance to an organism. Toxicity itself refers to the degree of being poisonous, or degree of harmful effects produced by a substance in an organism. Toxic effects can range from decreased performance to death. In general, even a metal that at normal levels has nutritive properties in large enough quantities can cause toxicity. In this chapter, the word "toxicity" will be used to indicate decreased performance of bottled phytoplankton assemblages in terms of decreased chlorophyll $a$ concentrations relative to a control treatment with no added $\mathrm{Cd}$.

There is also another, less well known toxicological dose response model called hormeisis. The hormetic dose-response curves can be considered in two ways, the first is a low-dose stimulatory and high-dose inhibitory response to physiological processes such as growth and the second is a low-dose reduction and high-dose enhancement of adverse effects such as carcinogenesis (Calabrese, 2005). The concept of hormeisis is especially relevant to both the study of $\mathrm{Cd}$ and of cyanobacteria in particular because $\mathrm{Cd}$ may be a nutrient at low concentrations and is also known to be toxic at higher concentrations and 
because cyanobacteria show responses at low dosages. In the case of $\mathrm{Cd}$, the hormetic response may be due to a pulse of cellular $\mathrm{Zn}$ release due to $\mathrm{Cd}$ exposure.

Cell size and natural vs. laboratory conditions can make a difference in the sensitivity of organisms to toxic substances. Prochlorococcus cells are smaller than Synechococcus cells. In considering sensitivity of organisms to toxic substances, a recent study by Echeveste et al. (2010) showed that smaller phytoplankton cells were more sensitive to exposure of polycyclic aromatic hydrocarbons (PAHs) than larger ones, particularly Synechococcus and Prochlorococcus and that natural communities were more sensitive to PAHs than cultures of phytoplankton.

The Costa Rica Upwelling dome in the summer of 2005 provided an ideal natural laboratory in which to compare a unique, Synechococcus-dominated environment to an oligotrophic, Prochlorococcus-dominated one. The cruise track included stations inside and outside the dome, allowing for comparisons between different phytoplankton assemblages. This study aims to address the duality of $\mathrm{Cd}$ as a nutrient or toxin in the marine environment by considering $\mathrm{Cd}$ bioavailability from multiple angles, using the tools of ${ }^{110} \mathrm{Cd}$ uptake experiments, toxicity studies, biological parameters and natural total dissolved and labile Cd measurements.

\section{METHODS}

\section{Preparation of Plasticware}

All sampling bottles and materials were rigorously cleaned to avoid metal contamination. All cleaning took place in a Class 100 clean room. Bottles were rinsed with $18.2 \mathrm{~m} \Omega$ Milli-Q (Millipore) water soaked overnight in 1\% citranox, rotated, soaked overnight, then rinsed seven times with Milli-Q water. The bottles were filled with 10\% $\mathrm{HCl}$ (Baker instra-analyzed) by volume and soaked for a minimum of a week, rotated, and soaked for another week. Bottles were rinsed seven times with $\mathrm{pH} 2 \mathrm{HCl}$ (Baker instra-analyzed) and stored double-bagged in plastic zip bags. Preparation of acid-clean tubes for holding water for nutrient analysis progressed the same as the trace-metal clean ones with the following exception. Instead of individually filling each tube, tubes were 
soaked in a $10 \% \mathrm{HCl}$ (Baker instra-analyzed) by volume bath for a week with stirring to ensure exposure of every surface to acid.

\section{Sample Collection}

Collection occurred during Cruise KN 182-05 aboard the R/V Knorr, July 17-29, 2005 from the Costa Rica Upwelling Dome (Figure 2.1, Table I.1). Water samples were collected using modified 10 L Go-Flo bottles (General Oceanics) suspended on a Kevlar line triggered with a Teflon messenger. Teflon coated O-rings replaced the standard Orings and Teflon plug valves replaced the standard stopcocks in the modified Go-Flo sampling devices (Bruland et al., 1979). Samples for electrochemical analysis of Cd totals were pressure-filtered through $142 \mathrm{~mm}, 0.4 \mu \mathrm{m}$ polycarbonate Nuclepore filters housed in a polycarbonate "filter sandwich" and stored in trace-metal clean polyethylene bottles. Samples for nutrient analysis were stored frozen in acid-cleaned $50 \mathrm{~mL}$ centrifuge tubes until analysis by Paul Henderson of the Nutrient Facility at WHOI. Water samples for time course stable isotope uptake experiments and toxicity experiments were collected using a trace-metal clean diaphragm pump that fed into a fifty-liter carboy in a positive pressure clean room environment made of laminar flow hoods and plastic sheeting.

\section{Chlorophyll a Estimation}

Shipboard chlorophyll $a$ measurements were made following the JGOFS procedure involving filtration onto $47 \mathrm{~mm} \mathrm{GF} / \mathrm{F}$ filters (Whatman), acetone extraction, acidification, and measurement on a fluorometer (JGOFS, 1994). Size-fractionated measurements were made using 2 and $10 \mu \mathrm{m}$ filters. A Picofluor hand-held fluorometer was used. GF/F filters slated for analysis in the lab were folded in half, wrapped in aluminum foil and frozen until analysis. A TD 7000 fluorometer was used and was calibrated using an Ultrospec 2100 pro and a chlorophyll $a$ standard (Sigma). Calibration of lab to shipboard chlorophyll data was performed in triplicate samples analyzed both shipboard and in the lab. 


\section{Flow Cytometry}

Flow cytometry samples were collected and preserved in $0.125 \%$ glutaraldehyde (Tousmis) incubated for 10 minutes in darkness and flash-frozen in liquid nitrogen. Samples were thawed in a water bath at $22^{\circ} \mathrm{C}$ for 5 minutes before analysis on an Influx cell sorter (Cytopeia) using $2 \mu \mathrm{m}$ fluorescent beads as an internal standard.

\section{$\mathrm{Cd}^{2+}$ Addition Experiments}

Bottle incubation experiments were performed with $0,0.5,1,1.5$, and $5 \mathrm{nM}$ total $\mathrm{Cd}^{2+}$ treatments in $1 \mathrm{~L}$ polycarbonate bottles with water from 8 or $15 \mathrm{~m}$ depth. These

concentrations are the total concentration of $\mathrm{Cd}^{2+}$ added and should be roughly equivalent to the final concentration assuming the original water was devoid of $\mathrm{Cd}$, no sorption to the walls of the bottle, and relatively little total incorporation into particles. Cd stocks were prepared from $3 \mathrm{CdSO}_{4} \cdot 8 \mathrm{H}_{2} \mathrm{O}$ and diluted with Milli-Q and $10 \% \mathrm{HCl}$ (Seastar) to $\mathrm{pH}$ 2 in polymethylpentene volumetric flasks. Bottles were cleaned between stations by rinsing, shaking and briefly soaking in $10 \% \mathrm{HCl}$, followed by five rinses of $\mathrm{pH} 2 \mathrm{HCl}$ (Baker instra-analyzed). $\mathrm{Cd}^{2+}$ additions were not pre-equilibrated with existing seawater, so the labile Cd could vary depending upon the amount of natural ligands that may have been present in the seawater previous to addition. Each treatment was done in triplicate and carried out in a positive pressure clean room environment. Bottles were incubated in an on-deck seawater flow-through incubator made with blue Plexiglass (35\% transmittance), the same light level for all depths. The Station 5 experiment incubated for four days, whereas experiments performed at Stations 11, 14, and 17 incubated for three days. Time zero chlorophyll $a$ measurements for Station 5 and 11, as well as final chlorophyll $a$ for Station 5 were performed shipboard. Time zero samples for Stations 14 and 17 as well as time final samples from Stations 11, 14, and 17 were frozen and analyzed in the laboratory on land.

\section{${ }^{110}$ Cd Stable Isotope Uptake Experiments}

When choosing a tracer, the relative abundance as well as ease of measurement need be considered. ${ }^{110} \mathrm{Cd}$ is intermediate in abundance and has a small potential for interference. ${ }^{106} \mathrm{Cd},{ }^{108} \mathrm{Cd}$, and ${ }^{116} \mathrm{Cd}$ have isobaric interferences from major $\mathrm{Pd}\left({ }^{106} \mathrm{Pd}\right.$ : 
$\sim 27 \%)$ or $\mathrm{Sn}\left({ }^{116} \mathrm{Sn}: \sim 14 \%\right)$ isotopes. ${ }^{112} \mathrm{Cd}$ and ${ }^{114} \mathrm{Cd}$ have isobaric interference with minor Sn nuclides with less than $1 \%$ relative abundances. ${ }^{110} \mathrm{Cd}$ and ${ }^{113} \mathrm{Cd}$ may have potential interferences with Pd and In, respectively (Ripperger and Rehkämper, 2007). ${ }^{111} \mathrm{Cd}$ has no isobaric interferences and would be a more ideal tracer, but ${ }^{110} \mathrm{Cd}$ was readily available and thus used. The $\mathrm{Cd}$ isotope spike was prepared by dissolving ${ }^{110} \mathrm{CdO}_{2}$ (Oak Ridge National Laboratory) in $5 \% \mathrm{HNO}_{3}$ (Seastar Baseline). Dilutions were made using Milli-Q. The spike was analyzed by ICP-MS to comprise $0.1 \mathrm{nM}{ }^{110} \mathrm{Cd}$, $0.0019 \mathrm{nM}{ }^{111} \mathrm{Cd}$, and $0.001 \mathrm{nM}{ }^{114} \mathrm{Cd}$. When added to filled $250 \mathrm{~mL}$ bottles, the added concentrations were $120 \mathrm{pM}{ }^{110} \mathrm{Cd}, 1.9 \mathrm{pM}{ }^{111} \mathrm{Cd}$, and $0.73 \mathrm{pM}{ }^{114} \mathrm{Cd}$.

An overall schematic for analyses associated with ${ }^{110} \mathrm{Cd}$ stable isotope uptake experiments is displayed in Figure 2.3. Samples for dissolved Cd analyses were filtered through a $0.4 \mu \mathrm{m}$ polycarbonate Nuclepore filter and stored in trace-metal clean polyethylene bottles until analysis by anodic stripping voltammetry (ASV). Experiments to discern ${ }^{110} \mathrm{Cd}$ particulate uptake were performed at depths varying from 8-600 $\mathrm{m}$. Bottles were incubated for 24 hours. Time course ${ }^{110} \mathrm{Cd}$ uptake experiments involved bottles being harvested after a combination of 3, 6, 12, 18, 24, 36 and 48 hours. All spike additions and consequent filtrations were carried out in a positive pressure clean room environment. Bottles were incubated in the on-deck incubator. The $120 \mathrm{pM}^{110} \mathrm{Cd}^{2+}$ spike was added to $250 \mathrm{~mL}$ polycarbonate bottles filled with unfiltered seawater and sealed tightly. Bottles were immediately transferred to the incubator.

Collection of biomass occurred by filtration of $200 \mathrm{~mL}$ of water at 5 psi onto acidcleaned $0.2 \mu \mathrm{m}$ polycarbonate GE Osmonics filters. The use of a $1 \mathrm{~mL}$ seawater rinse was implemented from Station 11 onwards (this did not appear to affect the results), and appropriate blanks were collected. Filters were stored frozen in trace-metal clean $1 \mathrm{~mL}$ tubes until lab analyses. Filter towers were rinsed with $\mathrm{pH} 2 \mathrm{HCl}$ between samples and with $10 \% \mathrm{HCl}$ (Baker instra-analyzed) at the end of each day. Filter blanks, filter tower blanks (placing the filter onto a cleaned tower) and seawater rinse blanks were collected periodically throughout the cruise. Polycarbonate bottles were cleaned between experiments with a rinse, shaking and a brief soak in $10 \% \mathrm{HCl}$, followed by a $\mathrm{pH} 2 \mathrm{HCl}$ 
rinse (Baker instra-analyzed). ${ }^{67} \mathrm{Zn}$ additions were also performed. These data are not discussed here, but the ${ }^{67} \mathrm{Zn}$ particulate results at each depth were used as the preexisting particulate $\mathrm{Cd}$ for calculating uptake in the ${ }^{110} \mathrm{Cd}$-spiked sample.

\section{${ }^{110}$ Cd Sample Acid Digestion and Inductively Coupled Plasma Mass Spectrometry} Analysis

All work was performed in a Class 100 clean room under a laminar flow hood. Acid digestion methodologies were developed after protocols reported in the literature (Cullen and Sherrell, 1999; Ellwood and Hunter, 1999, 2000; Hurst and Bruland, 2008).

Filters were removed from the freezer and transferred to trace metal clean Teflon or polypropylene vials. The filters were digested for 4 hours at $120^{\circ} \mathrm{C}$ in $50 \% \mathrm{HNO}_{3}$ (Seastar Baseline) and 2.5\% HF (Seastar Baseline) and the filters removed. After evaporation just to dryness, the residue was resuspended in $5 \% \mathrm{HNO}_{3}$ (Seastar Baseline) with a $1 \mathrm{ppb}$ indium internal standard and run on an Element II ICP-MS in low resolution mode, using an Aridus desolvator system.

Standards consisting of 1, 2, 3, and $4 \mathrm{ppb}$ total $\mathrm{Cd}$ and $\mathrm{Zn}(8.9-35.6 \mathrm{nM})$ with a $1.6 \mathrm{ppb}$ In internal standard were made and used to calculate $\mathrm{Cd}$ concentrations after ICPMS analysis. Natural Cd isotope abundances of the standards were assumed to calculate concentrations of ${ }^{110} \mathrm{Cd},{ }^{111} \mathrm{Cd}$ and ${ }^{114} \mathrm{Cd}$. Note that this method uses an overabundance of ${ }^{110} \mathrm{Cd}$ and should greatly outweigh any natural fractionation signals. It is not comparable to recent studies of natural $\mathrm{Cd}$ isotope fractionation using multi-collector ICP-MS, which can detect deviations in the ratio of ${ }^{114} \mathrm{Cd} /{ }^{110} \mathrm{Cd}$ with the precision of 2-6 parts per 10,000 (Ripperger and Rehkämper, 2007). Note also that there are response biases in ICP-MS that can cause a slight deviation of the measured isotopic ratio to deviate from the natural abundance isotope ratio. These deviations were not corrected for in these data and may be a few percent. 


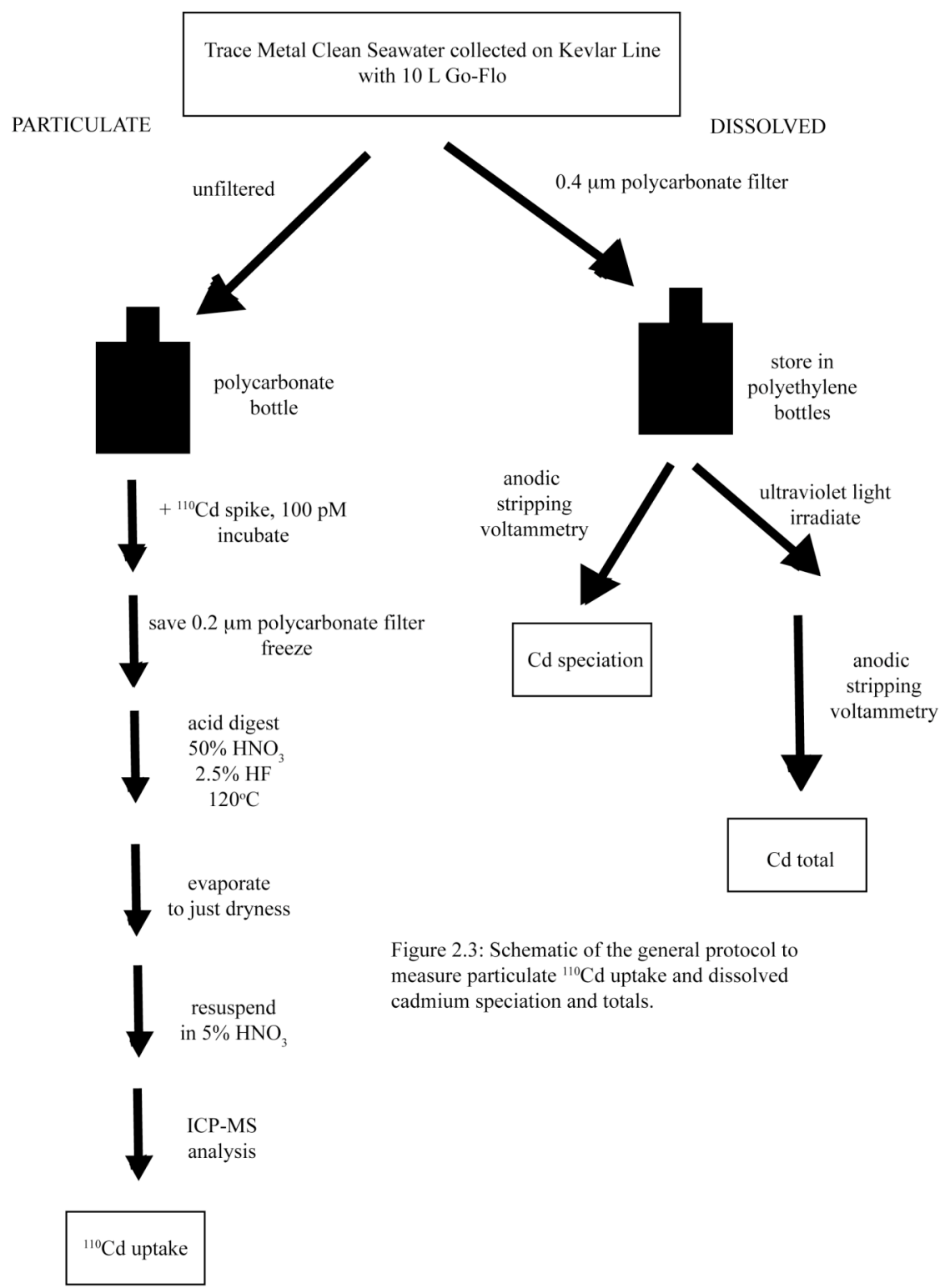

\section{Anodic Stripping Voltammetry Analyses of Total Dissolved Cadmium}

Total $\mathrm{Cd}$ measurements were performed using a mercury-plated rotating disc electrode (RDE). Protocols were based after Fischer et al., 1999 and Ellwood, 2004. At the beginning of each day, the RDE was polished with $\mathrm{AlO}_{2}$ and plated with $\mathrm{Hg}$. Plating occurred in a solution of $10 \mathrm{~mL}$ Milli-Q water, $50 \mu \mathrm{L}$ thiocyanate, $33 \mu \mathrm{L} 3 \mathrm{M} \mathrm{KCl}$ (Fluka puriss), and $1 \mathrm{~mL} 1000 \mathrm{ppm} \mathrm{Hg}$ reference solution (Fisher). The solution was purged for 10 minutes and plated at a current of $-1.5 \mathrm{~V}$ for 10 minutes. Total $\mathrm{Cd}$ concentrations were determined from samples that were UV irradiated for 2 hours by standard additions 
of $250 \mathrm{pM}$ Cd prepared from Fisher certified stock solutions diluted in pH 2 Milli-Q water and polymethylpentene volumetric flasks. A step potential of $9 \mathrm{mV}$, deposition potential of $-1.5 \mathrm{~V}$, and scan time of 3 minutes were used during the analyses. The detection limit is approximately $15 \mathrm{pM}$.

\section{RESULTS}

\section{Defining Inside and Outside the Dome}

The dome is biologically defined in this study as having an order of magnitude or greater Synechococcus cell numbers than outside the dome, in addition to the physical oceanographic context of a shoaled thermocline. Stations inside the dome had Synechococcus cell numbers equal to or greater than $2 \times 10^{5}$ cells $\mathrm{mL}^{-1}$ and an abundance of Synechococcus relative to Prochlorococcus by at least a factor of three to one. Stations outside the dome are dominated by Prochlorococcus by at least a factor of 3 and have Synechococcus cell numbers on order of $3.5 \times 10^{4}$ or less, almost an order of magnitude less than inside the dome. Stations 7, 11, 13 were considered to be inside the dome, Station 5 was intermediate and Stations 14, 15 and 17 were outside the dome. Station 5 is considered intermediate because it has Synechococcus cell numbers on order of $1 \times 10^{5}$, and almost equal cell numbers of Synechococcus and Prochlorococcus. Prochlorococcus dominates Synechococcus at Stations 14, 15, and 17.

\section{Calculating Cadmium Uptake Using ${ }^{110} \mathrm{Cd}$}

Total Cd uptake was calculated using the following equation, assuming that the spike was as available as the existing $\mathrm{Cd}$ :

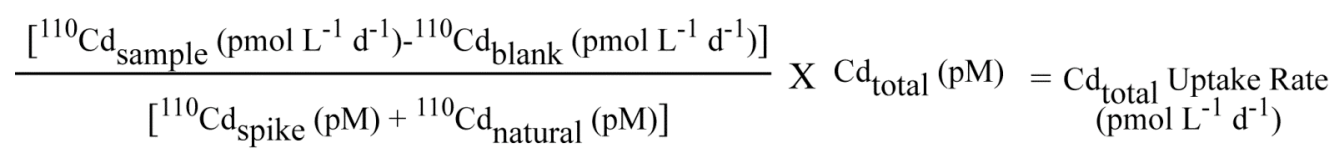

${ }^{110} \mathrm{Cd}_{\text {sample }}$ (in units of pmol L $\mathrm{L}^{-1} \mathrm{~d}^{-1}$ ) is the particulate ${ }^{110} \mathrm{Cd}$ measured using ICP-MS of the filter, normalized to volume of seawater and one day of incubation. A difference between radiotracers such as ${ }^{57} \mathrm{Co}$ is that there may be ${ }^{110} \mathrm{Cd}_{\text {sample }}$ already in the particulate fraction. This was accounted for by subtracting the particulate blank, ${ }^{110} \mathrm{Cd}_{\text {blank }}$. Particulate ${ }^{110} \mathrm{Cd}_{\text {blank }}$ will hereafter be referred to as preexisting particulate 
${ }^{110} \mathrm{Cd}$. The particulate blank bottle in these experiments had ${ }^{67} \mathrm{Zn}$ added, but no $\mathrm{Cd}$ spike. The ${ }^{67} \mathrm{Zn}$ spike was confirmed to contain virtually no ${ }^{110} \mathrm{Cd},{ }^{111} \mathrm{Cd}$, or ${ }^{114} \mathrm{Cd}$. The ${ }^{67} \mathrm{Zn}$ added to this bottle should not affect the preexisting $\mathrm{Cd}$. Preexisting $\mathrm{Cd}$ is measured in units of pmol L-1 $\mathrm{d}^{-1}$. It is assumed that the particulate blank is in steady state, i.e. it represents the $\mathrm{Cd}$ already in the particulate fraction and any possible natural uptake that could occur during incubation for twenty-four hours is negligible. Dividing the particulate ${ }^{110} \mathrm{Cd}$ by the total dissolved ${ }^{110} \mathrm{Cd}$ yields the fraction of ${ }^{110} \mathrm{Cd}$ that has moved from the dissolved pool to the particulate pool per day. The total dissolved ${ }^{110} \mathrm{Cd}$ is comprised of the dissolved ${ }^{110} \mathrm{Cd}$ added as a spike plus any natural, preexisting dissolved ${ }^{110} \mathrm{Cd}$ (Figure 2.4c). The natural preexisting ${ }^{110} \mathrm{Cd}$ was calculated by multiplying the total dissolved Cd measured by ASV (Figure 2.4a) by the natural abundance of ${ }^{110} \mathrm{Cd}, 0.1249$ (Figure 2.4b).

When there is very little natural total dissolved $\mathrm{Cd}$, as occurs in the surface waters, ${ }^{110} \mathrm{Cd}_{\text {natural }}$ approaches zero, $\mathrm{Cd}_{\text {total }}$ approaches ${ }^{110} \mathrm{Cd}_{\text {spike }}$ and they cancel out of the equation. Total $\mathrm{Cd}$ uptake is then represented entirely by ${ }^{110} \mathrm{Cd}$ uptake. One could then consider this a sort of potential uptake, since the natural dissolved $\mathrm{Cd}<<{ }^{110} \mathrm{Cd}_{\text {spike }}$ at these depths. As natural total dissolved $\mathrm{Cd}$ increases with depth, the uptake of the tracer is diluted (Figure 2.4c). Using one group of procedural blanks measured using ICP-MS $(n=4)$, the detection limit for particulate Cd uptake rate with one standard deviation error is $0.021 \pm 0.007 \mathrm{pmol} \mathrm{L}^{-1} \mathrm{~d}^{-1}$.

Depth profiles of ${ }^{110} \mathrm{Cd}$ uptake rate, total dissolved $\mathrm{Cd}$, total and size-fractioned chlorophyll a, and Prochlorococcus and Synechococcus cell numbers at Station 11, inside the dome are shown in Figure 2.4, data in Appendix I (Table I.2). The dissolved ${ }^{110} \mathrm{Cd}$ spike added to the bottle from each depth (120 pM) is shown in Figures 2.4a, b, and c. The dissolved ${ }^{110} \mathrm{Cd}$ spike is greater than the natural, total dissolved $\mathrm{Cd}$ at depths shallower than $40 \mathrm{~m}$ (Figure 2.4a). The spike is greater than the natural dissolved ${ }^{110} \mathrm{Cd}$ at every depth (Figure 2.4b). When the spike is added, it contributes a significant amount of the total dissolved $\mathrm{Cd}$ at shallow depth, but the contribution decreases with depth as total dissolved $\mathrm{Cd}$ increases. ${ }^{110} \mathrm{Cd}$ particulate uptake rates are detectable shallower than 
$40 \mathrm{~m}$ (Figure 2.4d), consistent with total dissolved Cd depletion (Figure 2.4a) and higher biomass in surface waters (Figure $2.4 \mathrm{~d}$, e).
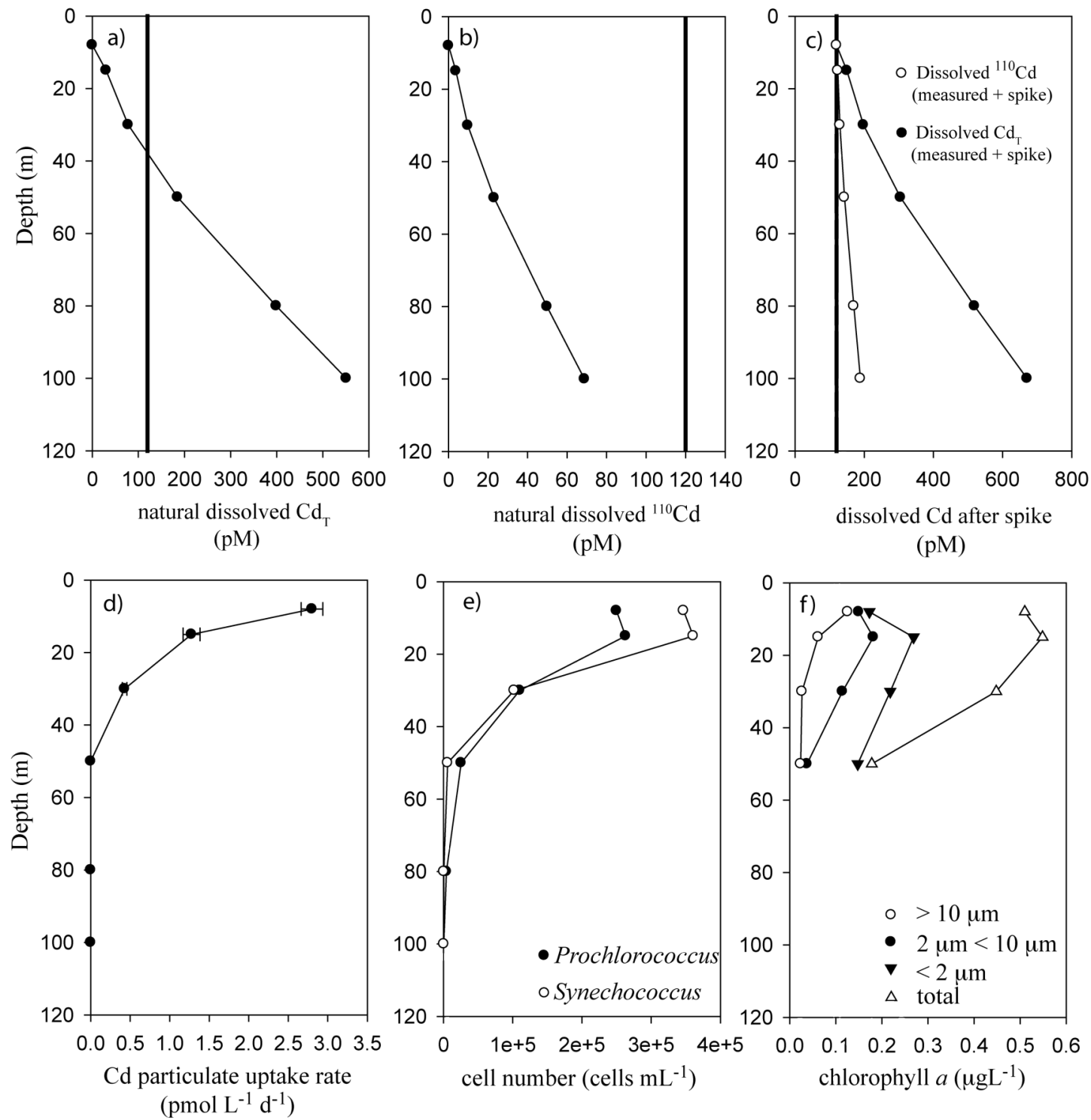

Figure 2.4: Station 11, inside the dome. Depth profiles of natural total dissolved Cd, total dissolved Cd after adding ${ }^{110} \mathrm{Cd}$ spike, particulate $\mathrm{Cd}$ uptake rate, Synechococcus and Prochlorococcus cell numbers, and total and size-fractionated chlorophyll $a$. a) Natural, total dissolved Cd. b) Natural, total dissolved ${ }^{110} \mathrm{Cd}$. c) Total dissolved $\mathrm{Cd}$ and ${ }^{110} \mathrm{Cd}$ in each bottle with spike added. d) $\mathrm{Cd}$ particulate uptake rates relative to control. Error bars indicate counting error of a single measurement. e) Synechococcus and Prochlorococcus cell numbers, f) Size-fractionated chlorophyll $a$. Solid lines in a), b) and c) represent $120 \mathrm{pM}$ of ${ }^{110} \mathrm{Cd}$ spike added, total dissolved Cd added is 122.5 pM. Data in Appendix I, Table I.2. 
Isotope ratios can also be examined to track uptake of the spike, in addition to increased amounts of ${ }^{110} \mathrm{Cd}$ in the particulate phase. A depth profile of particulate isotope ratios from Station 11, inside the dome, is shown in Figure 2.5, data in Appendix I (Table I.4). Particulate isotope ratios of ${ }^{114} \mathrm{Cd} /{ }^{110} \mathrm{Cd}$ and ${ }^{111} \mathrm{Cd} /{ }^{110} \mathrm{Cd}$ are lower relative to natural abundance (Figure 2.5a), whereas in the preexisting particulate $\mathrm{Cd}$ samples, isotope ratios are relatively consistent with natural abundance ratios (Figure 2.5b). Error bars represent propagation of root mean square deviation of one measurement, instrument counting error. Similarly, in the ${ }^{110} \mathrm{Cd}$ time course experiment for Station $11,{ }^{114} \mathrm{Cd} /{ }^{10} \mathrm{Cd}$ and ${ }^{111} \mathrm{Cd} /{ }^{110} \mathrm{Cd}$ particulate ratios are lower than natural abundance and decrease with time (Figure 2.6, Table 2.5). 


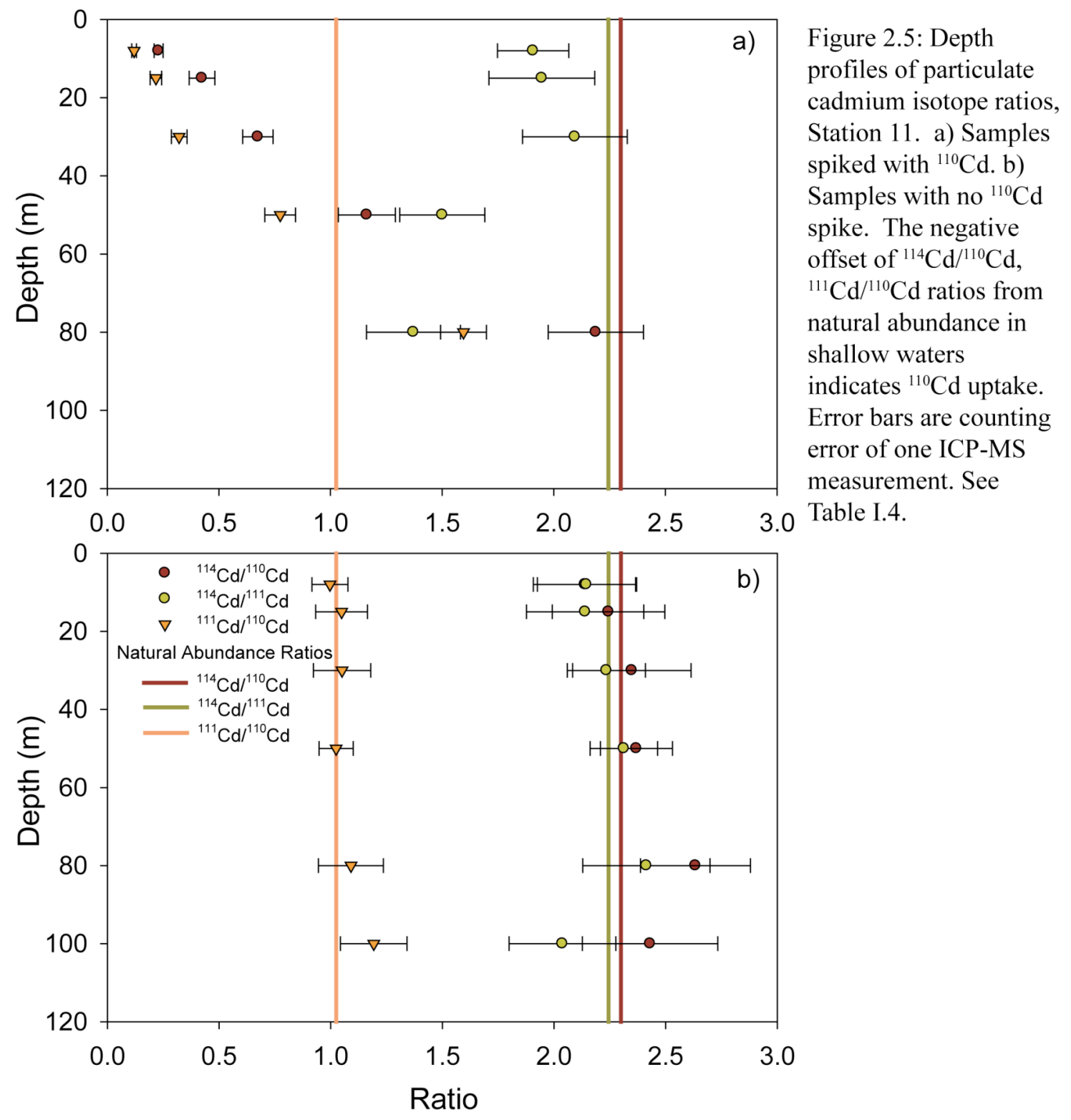




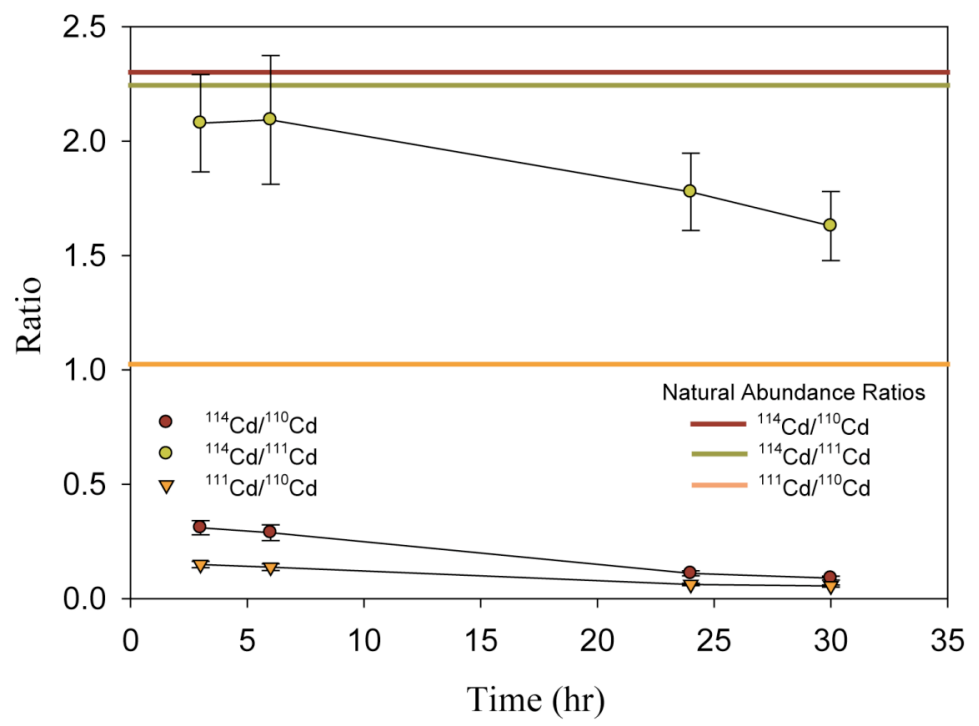

Figure 2.6: ${ }^{114} \mathrm{Cd} /{ }^{110} \mathrm{Cd},{ }^{111} \mathrm{Cd} /{ }^{110} \mathrm{Cd}$ and ${ }^{114} \mathrm{Cd} /{ }^{111} \mathrm{Cd}$ particulate cadmium ratios with time for Station 11 samples spiked with ${ }^{110} \mathrm{Cd}$. The negative offset of ${ }^{114} \mathrm{Cd} /{ }^{110} \mathrm{Cd},{ }^{111} \mathrm{Cd} /{ }^{110} \mathrm{Cd}$ ratios from natural abundance and decrease of these ratios with time indicate uptake of the spike, ${ }^{110} \mathrm{Cd}$. See Table I.5.

Outside the dome, a similar phenomenon is observed. Depth profiles of ${ }^{110} \mathrm{Cd}$ uptake, total dissolved $\mathrm{Cd}$, total and size-fractioned chlorophyll $a$ and Prochlorococcus and Synechococcus cell numbers at Station 17, outside the dome are shown in Figure 2.7, data in Table I.3. ${ }^{110} \mathrm{Cd}$ particulate uptake rates are detectable shallower than $40 \mathrm{~m}$ (Figure 2.7a, d), consistent with total dissolved Cd depletion (Figure 2.7b) and higher biomass in surface waters (Figure 2.7c, e, f). 

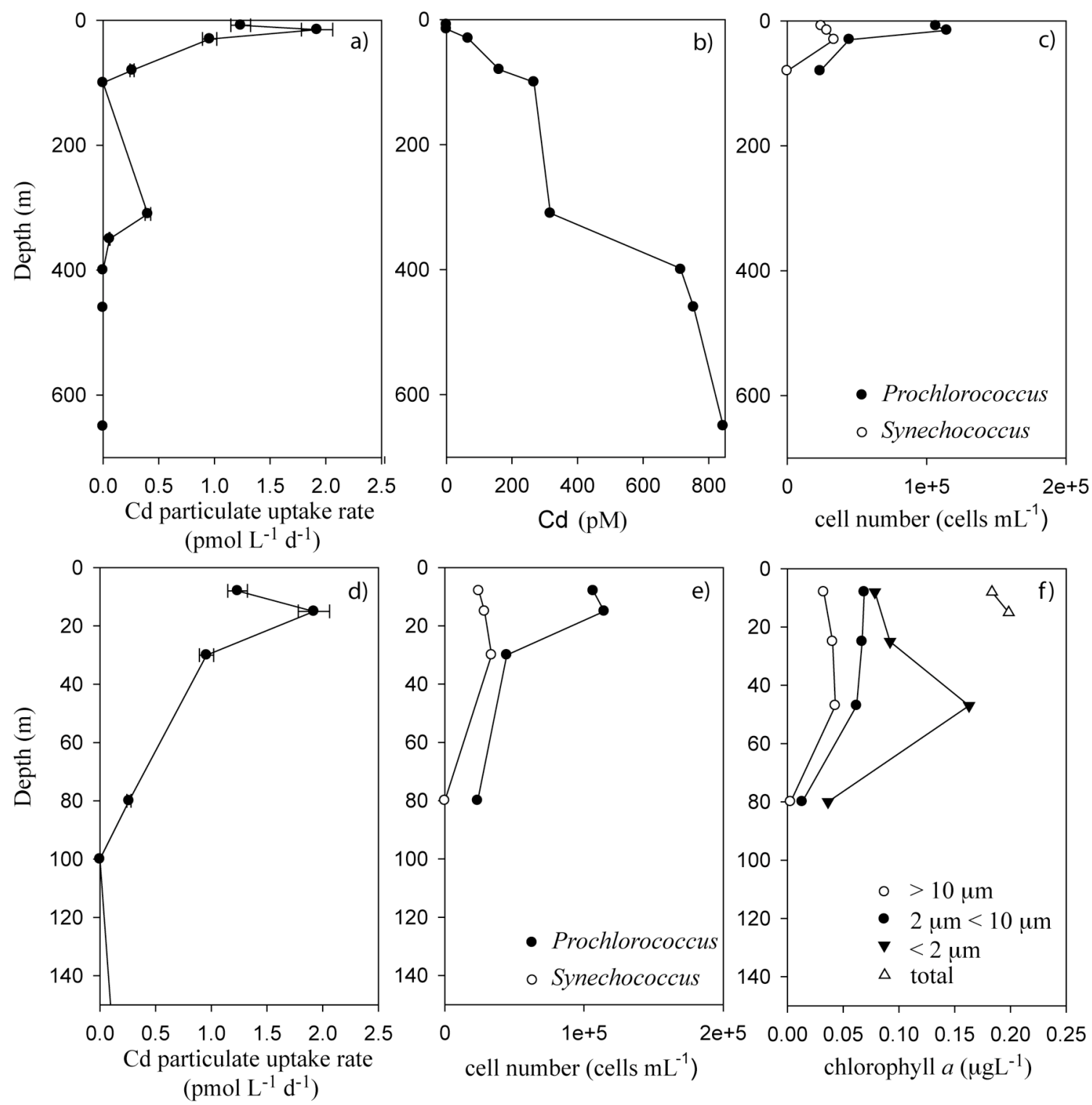

Figure 2.7: Station 17, outside the dome. Depth profiles of particulate Cd uptake, total dissolved cadmium, Synechococcus and Prochlorococcus cell numbers, and total and size-fractionated chlorophyll $a$. a) Cd particulate uptake rates. b) Total dissolved cadmium. c) Synechococcus and Prochlorococcus cell numbers. d) Particulate Cd uptake rates. e) Synechococcus and Prochlorococcus cell numbers. f) Size-fractionated chlorophyll $a$. Note difference in depth scale for d), e), and f). Note that two sets of the size-fractionated chlorophyll $a$ measurements were not at the exact depths as the other measurements, the alternate depths are 25 and $47 \mathrm{~m}$. See Table I.3.

Particulate Cd uptake in pmol L ${ }^{-1}$ vs. time is plotted in Figure 2.8 for time course experiments at Stations 5, 7, 11,13,15, and 17. Slope of the line yields a Cd uptake rate in pmol L $\mathrm{L}^{-1} \mathrm{~d}^{-1}$. These calculations yield similar uptake rates to those calculated using a single 24-hour time point (Table 2.2), suggesting that using one 24-hour time point at a 
given station and depth is an adequate estimate of total $\mathrm{Cd}$ uptake. These samples are not corrected for natural dissolved $\mathrm{Cd}$ because it was not measured at three of the stations (Stations 7, 13, and 15) and total dissolved Cd was undetectable at the other three stations (Stations 5, 11, and 17). Because total dissolved $\mathrm{Cd}$ was undetectable, ${ }^{110} \mathrm{Cd}$ uptake is equal to total $\mathrm{Cd}$ uptake and this assumption is extended to the other three stations.

These samples are also not corrected for preexisting particulate Cd. See Figure 2.9 for a brief discussion on the need to correct for preexisting particulate $\mathrm{Cd}$.

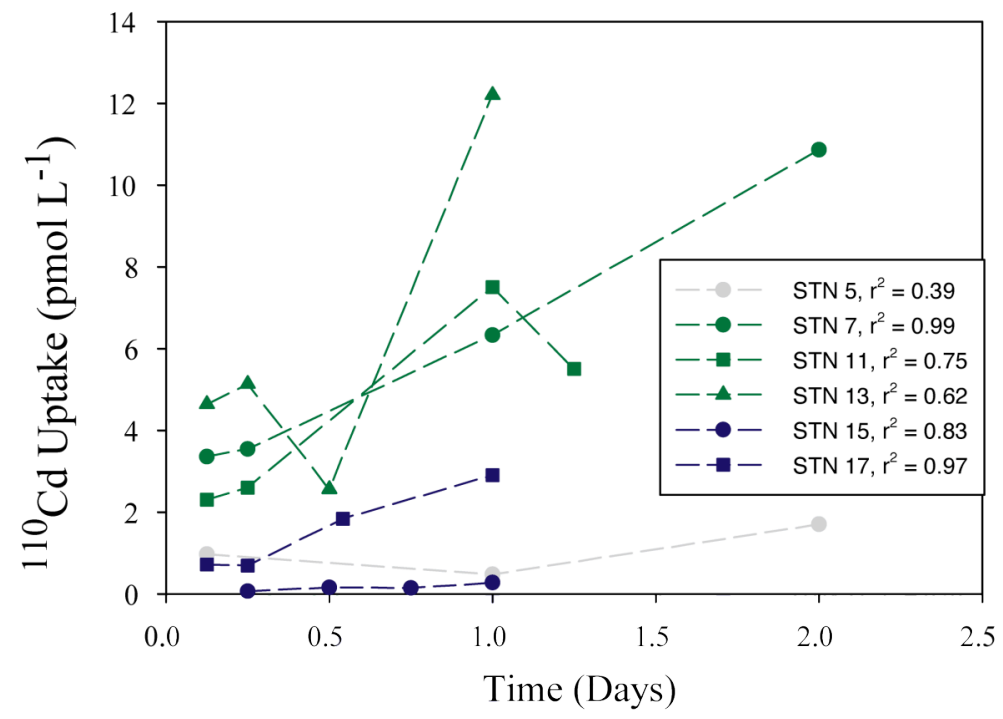

Figure $2.8:{ }^{110} \mathrm{Cd}$ particulate uptake vs. time. Time course uptake experimental results at Stations 5, 7, $11,13,15$, and 17 from $15 \mathrm{~m}$ depth. Slopes of lines yield $\mathrm{Cd}$ uptake rates in pmol $\mathrm{L}^{-1} \mathrm{~d}^{-1}$. See Table 2.2 and I.6.

Table 2.2: Calculated particulate ${ }^{110} \mathrm{Cd}$ uptake rates from time course experiments and one 24 -hour point

\begin{tabular}{lcccc} 
Station & $\begin{array}{c}\text { Cd Uptake Rate } \\
\left(\mathrm{pmol} \mathrm{L} \mathrm{d}^{-1}\right) \\
\text { from slope }\end{array}$ & $\mathrm{r}^{2}$ & $\begin{array}{c}\text { Cd Uptake Rate } \\
\left(\mathrm{pmol} \mathrm{L}^{-1} \mathrm{~d}^{-1}\right) \\
\text { from 24 hour }\end{array}$ & $\begin{array}{c}\text { Cd Uptake Rate } \\
\left(\mathrm{pmol} \mathrm{L}^{-1} \mathrm{~d}^{-1}\right)\end{array}$ \\
\hline 5 & 0.42 & 0.39 & 0.47 & 0.05 \\
7 & 4.05 & 0.99 & 6.33 & 0.53 \\
11 & 3.89 & 0.75 & 7.5 & 0.55 \\
13 & 8.56 & 0.62 & 12.2 & 1.31 \\
15 & 0.24 & 0.83 & 0.27 & 0.02 \\
17 & 2.7 & 0.97 & 2.9 & 0.22 \\
\hline
\end{tabular}

See Figure 2.12. Particulate Cd uptake rate calculated from slope of ${ }^{110} \mathrm{Cd}$ uptake vs. time. Particulate $\mathrm{Cd}$ uptake rate calculated from ${ }^{110} \mathrm{Cd}$ concentration at a time of 24 hours divided by one day. Errors on particulate $\mathrm{Cd}$ uptake rate are counting errors from a single ICP-MS measurement. 


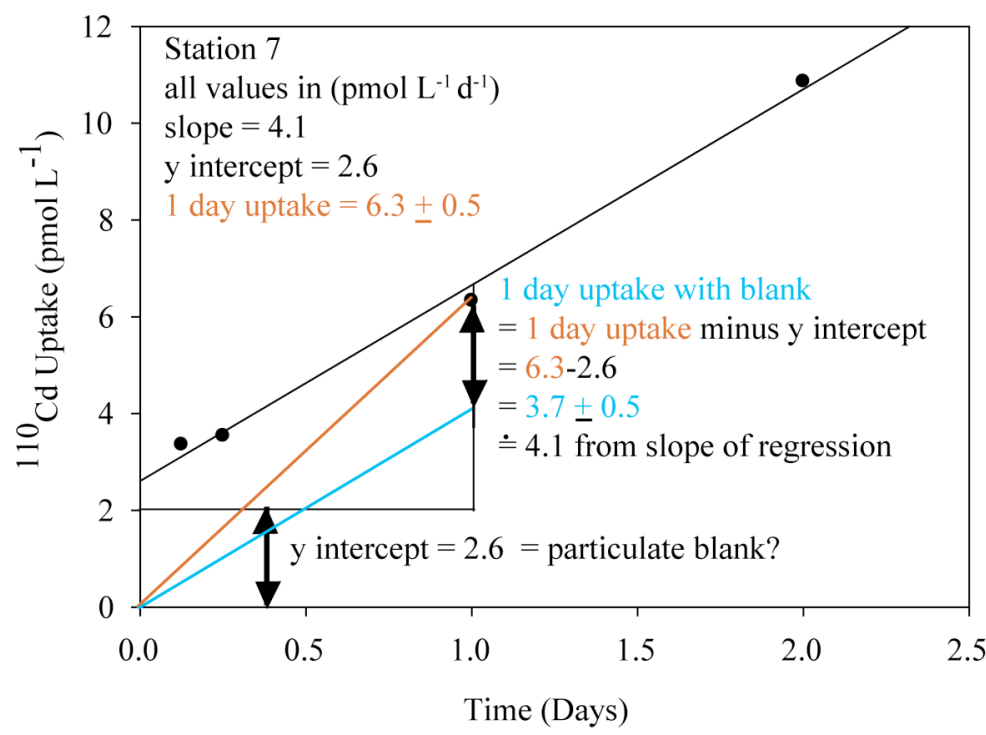

Figure 2.9: Argument for a particulate blank correction, more necessary with increasing inital biomass. Time course uptake points from Station 7. When the $y$-intercept from the slope of regression line is subtracted from the 1 day time point, an uptake rate is obtained that is within error of the uptake rate obtained from the slope of the regresson line. Red and blue colors indicate non-corrected and corrected values, respectively.

\section{Cadmium Addition Experiments}

At the initial time of $\mathrm{Cd}$ addition, Station 11, inside the dome, had three times more total chlorophyll $a$ than the other stations; the total concentration was $366 \mathrm{ng} \mathrm{L}^{-1}$. Stations 5, 14, and 17 had relatively similar initial chlorophyll $a$ concentrations of 115 , 78 and $124 \mathrm{ng} \mathrm{L}^{-1}$ respectively (Figure 2.10a, Table 2.3). Stations 5 and 11, intermediate and inside the dome have higher Synechococcus cell numbers, $1.3 \times 10^{5}$ and $3.6 \times 10^{5}$ cells $\mathrm{mL}^{-1}$, relative to Stations 14 and 17 , which are outside the dome and have approximately an order of magnitude less Synechococcus cells, $3.5 \times 10^{4}$ and $2.9 \times 10^{4}$ cells $\mathrm{mL}^{-1}$, respectively (Figure $2.10 \mathrm{~b}$, Table 2.3). Prochlorococcus cell numbers are on the order $10^{5}$ cells $\mathrm{mL}^{-1}$ at all four stations, so Stations 14 and 17 have an order of magnitude more Prochlorococcus than Synechococcus (Figure 2.10b, Table 2.3). 


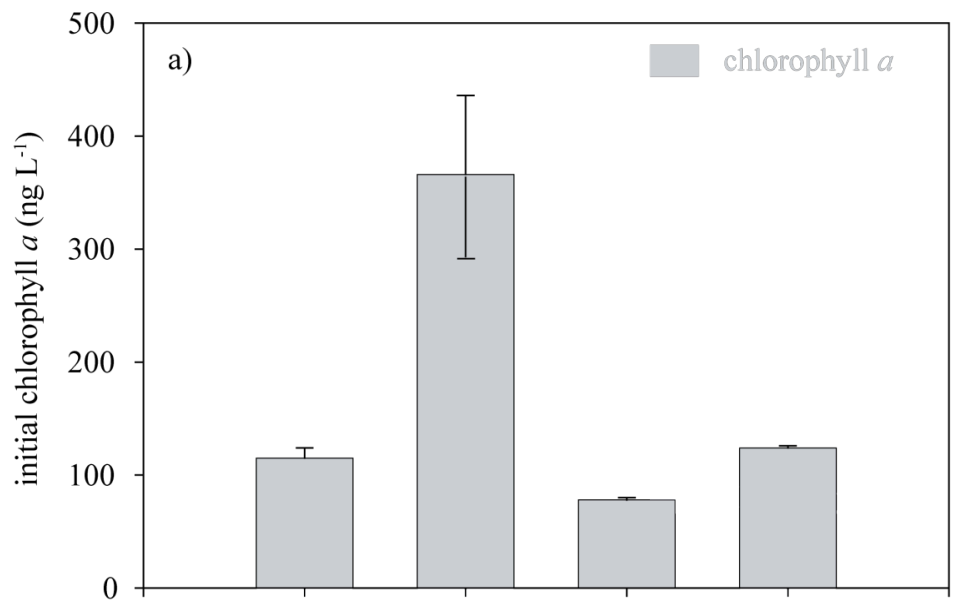

Figure 2.10: Initial chlorophyll $a$ and cyanobacterial cell numbers for cadmium addition experiments. a) Initial chlorophyll $a$ concentrations. Error bars represent one standard deviation of triplicate measurements. b) Inital Synechococcus and Prochlorococcus cell numbers. Note that Station 5 (intermediate in terms of the dome) had low initial chlorophyll $a$ concentrations, comparable to Stations 14 and 17 (outside the dome), but like Station 11, a greater abundance of Synechococcus cells. See Table 2.3.

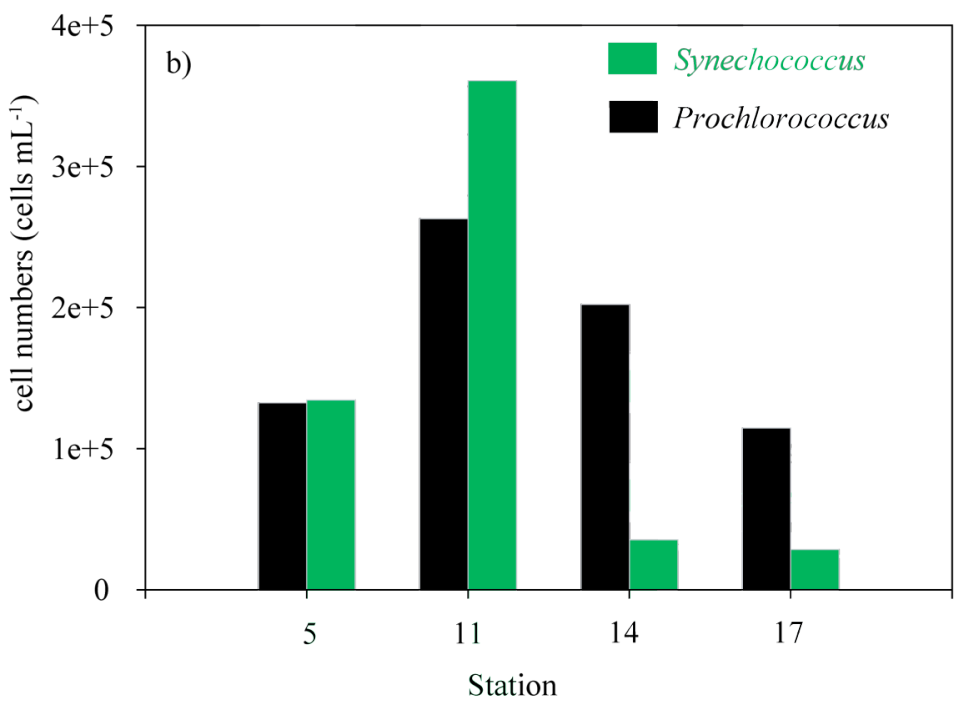

The control treatments in all stations increased in chlorophyll $a$ concentration relative to initial conditions by $13 \%, 105 \%, 88 \%$ and $247 \%$ for Stations $5,11,14$, and 17 respectively (Figure 2.11, compare solid to dashed lines). Note that Station 5 effectively did not grow, the initial and final chlorophyll $a$ concentrations are within error. Other incubations performed on this same cruise at this station investigating the effects of cobalt, iron and DFB (desferrioxamine B) showed an approximately two-fold decrease in Synechococcus cell abundance in the control treatment at harvest compared to initial abundance, with an approximately two-fold increase in Prochlorococcus cell abundances in the control (Thompson, 2009). When Cd concentrations were artificially enhanced by 0.5 to $5 \mathrm{nM}$ in three to four day bottle incubations, chlorophyll $a$ was reduced relative to the control by $10 \%$ for at least three of the Cd treatments at all four stations (Figure 2.11, 
Table 2.3). At Station 5, chlorophyll $a$ was reduced by $10 \%$ under $0.5,1.5$, and $5 \mathrm{nM}$ $\mathrm{Cd}^{2+}$ additions (Figure 2.11a, Table 2.3). At Station 11, chlorophyll $a$ was reduced by $10 \%$ under $0.5,1,1.5$, and $5 \mathrm{nM} \mathrm{Cd}^{2+}$ additions (Figure 2.11b, Table 2.3). At Station 14, chlorophyll $a$ was reduced by $10 \%$ under $1,1.5$, and $5 \mathrm{nM} \mathrm{Cd}^{2+}$ additions (Figure $2.11 \mathrm{c}$, Table 2.3). At Station 17, chlorophyll $a$ was reduced by $10 \%$ under $0.5,1,1.5$, and $5 \mathrm{nM}$ $\mathrm{Cd}^{2+}$ additions (Figure 2.11d, Table 2.3). Chlorophyll $a$ was reduced relative to the control by $50 \%$ under $5 \mathrm{nM} \mathrm{Cd}^{2+}$ addition at Station 17 (Figure 2.11d, Table 2.3). A greater decrease in chlorophyll $a$ with increasing $\mathrm{Cd}^{2+}$ additions was observed at Stations 14 and 17 (Figure 2.11c and 2.11d).
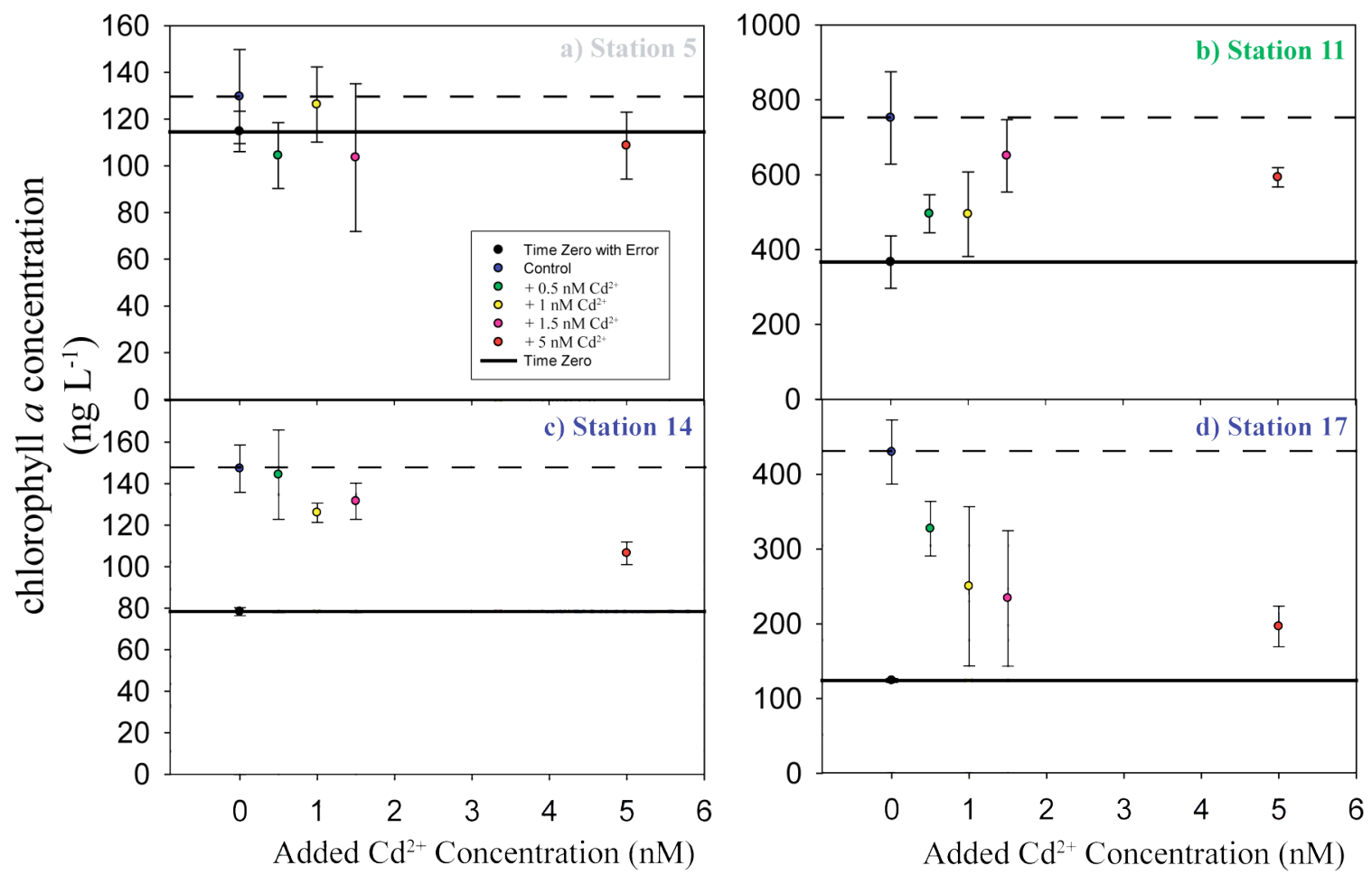

Figure 2.11: Chlorophyll $a$ in ng $\mathrm{L}^{-1}$ with range of $\mathrm{Cd}^{2+}$ treatments for four stations after three days. a) Station 5 , intermediate in terms of the dome. b) Station 11, inside the dome. c) Station 14, outside the dome. d) Station 17, outside the dome. Error bars are standard deviations of triplicate bottles. Solid line indicates time zero chlorophyll $a$ concentration. Dotted line indicates time final chlorophyll $a$ concentration in the no added $\mathrm{Cd}^{2+}$. Note that the incubation at Station 5 ran for four days. See Table 2.3. 
Table 2.3: Initial conditions and chlorophyll $a$ results, $\mathrm{Cd}^{2+}$ addition experiments

\begin{tabular}{|c|c|c|c|c|}
\hline $\begin{array}{l}\text { Station } \\
\text { Depth } \\
\text { Inital } \mathrm{Cd}_{\mathrm{T}}\end{array}$ & $\begin{array}{c}\text { Total Cd } \\
\text { Added } \\
(\mathrm{nM})\end{array}$ & $\begin{array}{l}\text { chlorophyll } a \\
\quad\left(\mathrm{ng} \mathrm{L}^{-1}\right)\end{array}$ & $\begin{array}{l}\text { Prochlorococcus } \\
\quad \text { (cells } \mathrm{mL}^{-1} \text { ) }\end{array}$ & $\begin{array}{c}\text { Synechococcus } \\
\text { (cells } \mathrm{mL}^{-1} \text { ) }\end{array}$ \\
\hline $\begin{array}{l}\text { Station } 5 \\
15 \mathrm{~m} \\
\text { nd }\end{array}$ & $\begin{array}{l}\text { Time Zero } \\
0 \\
0.5^{*} \\
1 \\
1.5^{*} \\
5^{*}\end{array}$ & $\begin{array}{l}115 \pm 20 \\
130 \pm 20 \\
104 \pm 14 \\
126 \pm 16 \\
104 \pm 32 \\
109 \pm 14\end{array}$ & $1.32 \times 10^{5}$ & $1.34 \times 10^{5}$ \\
\hline $\begin{array}{l}\text { Station } 11 \\
15 \mathrm{~m} \\
\text { nd }\end{array}$ & $\begin{array}{l}\text { Time Zero } \\
0 \\
0.5^{*} \\
1^{*} \\
1.5^{*} \\
5^{*}\end{array}$ & $\begin{array}{l}366 \pm 70 \\
752 \pm 124 \\
495 \pm 51 \\
494 \pm 113 \\
650 \pm 97 \\
593 \pm 26\end{array}$ & $2.63 \times 10^{5}$ & $3.61 \times 10^{5}$ \\
\hline $\begin{array}{l}\text { Station } 14 \\
8 \mathrm{~m} \\
57 \mathrm{pM}\end{array}$ & $\begin{array}{l}\text { Time Zero } \\
0 \\
0.5 \\
1^{*} \\
1.5^{*} \\
5^{*}\end{array}$ & $\begin{array}{l}78 \pm 2 \\
147 \pm 11 \\
144 \pm 21 \\
126 \pm 5 \\
132 \pm 9 \\
106 \pm 5\end{array}$ & $2.02 \times 10^{5}$ & $3.54 \times 10^{4}$ \\
\hline $\begin{array}{l}\text { Station } 17 \\
15 \mathrm{~m} \\
\text { nd }\end{array}$ & $\begin{array}{l}\text { Time Zero } \\
0 \\
0.5^{*} \\
1^{*} \\
1.5^{*} \\
5^{* *}\end{array}$ & $\begin{array}{l}124 \pm 2 \\
430 \pm 43 \\
327 \pm 36 \\
250 \pm 106 \\
234 \pm 91 \\
196 \pm 27\end{array}$ & $1.14 \times 10^{5}$ & $2.85 \times 10^{4}$ \\
\hline
\end{tabular}

See Figures 2.10 and 2.11. Depths water was collected for bottle incubation and initial dissolved total cadmium concentrations are listed under the station. Errors on chl $a$ standard deviation are from three replicate bottles. * $=$ decrease of $10 \%$ in chlorophyll $a$ concentration relative to control at time final. $* *=$ decrease of $50 \%$ in chlorophyll a concentration relative to control at time final. 


\section{${ }^{110}$ Cd Uptake at Seven Stations Compared to Biological Parameters}

As shown in Figure 2.12a, c, higher uptake rates occurred at Stations 7, 11 and 13, 6.1, 2.8 and $2.8 \mathrm{pmol} \mathrm{L}^{-1} \mathrm{~d}^{-1}$, respectively, inside the dome than at intermediate Station 5, $1.3 \mathrm{pmol} \mathrm{L}^{-1} \mathrm{~d}^{-1}$ and the stations outside the dome, 14,15 , and 17, 0.2, 0.96, and $1.9 \mathrm{pmol}$ $\mathrm{L}^{-1} \mathrm{~d}^{-1}$, respectively (Table 2.4). Linear regressions of particulate ${ }^{110} \mathrm{Cd}$ uptake vs. biological measurements of Synechococcus and Prochlorococcus cell abundances and total chlorophyll $a$ for maximum particulate ${ }^{110} \mathrm{Cd}$ uptake depth at these seven stations yielded weak to moderate correlations. The highest correlation was with total chlorophyll $a$, having an $\mathrm{r}^{2}$ value of 0.75 . 


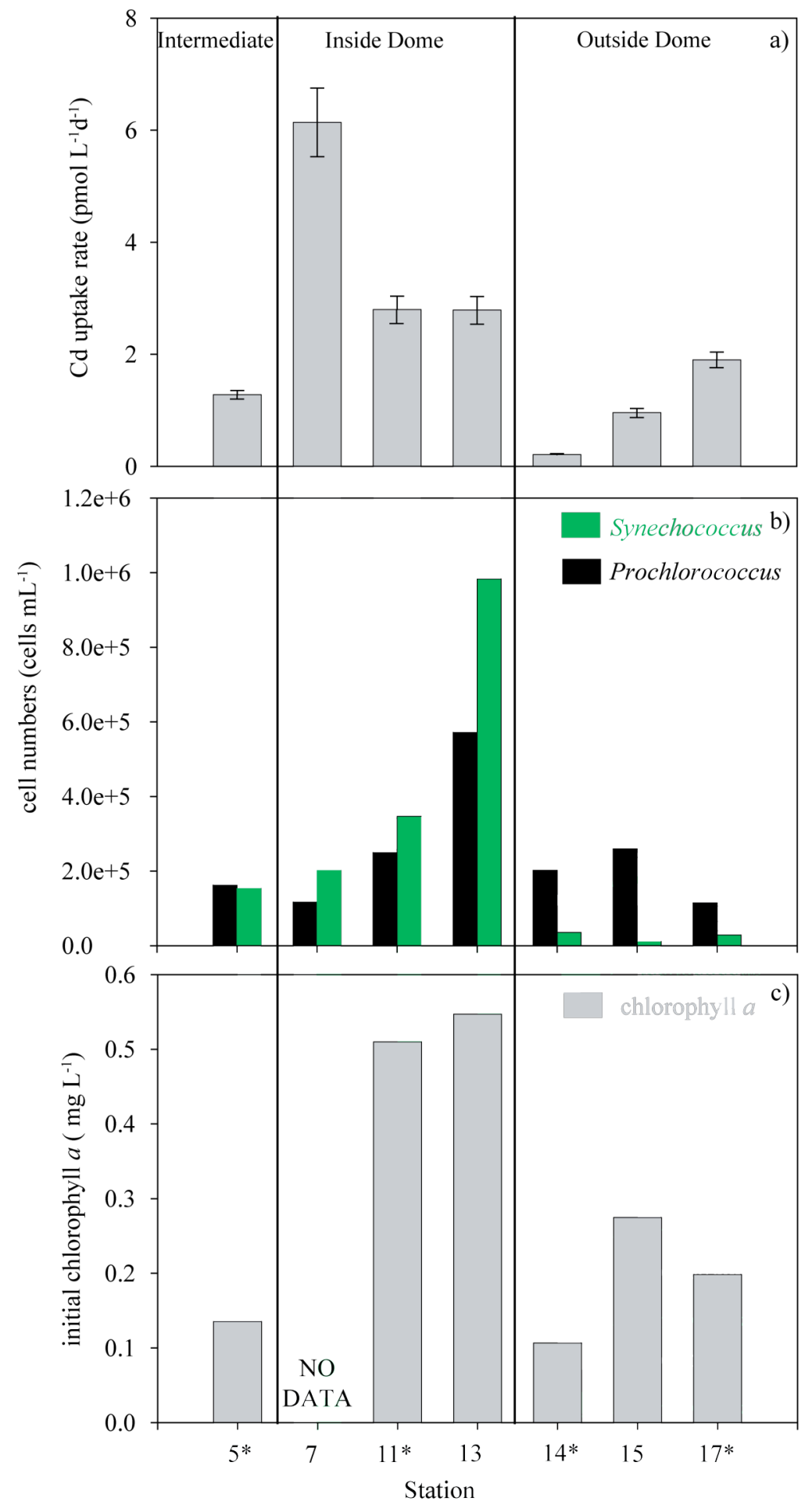

Figure 2.12: Maximum Cd uptake rates, Synechococcus and Prochlorococcus cell numbers per $\mathrm{mL}$, and chlorophyll $a$ concentrations at a depth of $15 \mathrm{~m}$ for stations discussed in this paper. a) Maximum $\mathrm{Cd}$ uptake rates. Error bars represent counting error of a single ICP-MS measurement. b) Cyanobacteial cell numbers. c) Chlorphyll $a$ concentrations. * = $\mathrm{Cd}$ additon experiment performed. Notice that Stations 7, 11 and 13 have higher Synechococcus counts (inside the dome) relative to Stations 14, 15 and 17 (outside the dome). Station 5 has approximately equal counts (intermediate). Prochlorococcus dominates Synechococcus at Stations 14, 15, and 17. Note that higher uptake rates tend to occur in stations inside the dome and with higher chlorophyll $a$. Note that data for Station 14 are from a depth of $8 \mathrm{~m}$ and uptake rate for Station 7 was measured using surface pump water and not a Go-flo bottle. See Table 2.4. 
Table 2.4: Maximum particulate $\mathrm{Cd}$ uptake rates, cyanobacterial cell numbers and chlorophyll $a$ concentrations

\begin{tabular}{lccccc} 
Station & $\begin{array}{c}\text { Depth } \\
(\mathrm{m})\end{array}$ & $\begin{array}{c}\text { Cd Uptake Rate Prochlorococcus Synechococcus } \\
\left(\mathrm{pmol} \mathrm{L}^{-1} \mathrm{~d}^{-1}\right)\end{array}$ & $\begin{array}{c}\mathrm{chl} \mathrm{a} \\
\left(\text { cells } \mathrm{mL}^{-1}\right)\end{array}$ & $\begin{array}{c}\left.\text { (cells } \mathrm{mL}^{-1}\right) \\
\left(\mathrm{ng} \mathrm{L}^{-1}\right)\end{array}$ \\
\hline 5 & 8 & $1.28 \pm 0.07$ & $1.62 \times 10^{5}$ & $1.54 \times 10^{5}$ & 0.135 \\
7 & 15 & $6.14 \pm 0.61$ & $1.17 \times 10^{5}$ & $2.01 \times 10^{5}$ & $\mathrm{~nm}$ \\
11 & 8 & $2.8 \pm 0.24$ & $2.50 \times 10^{5}$ & $3.47 \times 10^{5}$ & 0.510 \\
13 & 8 & $2.79 \pm 0.24$ & $5.72 \times 10^{5}$ & $9.84 \times 10^{5}$ & 0.547 \\
14 & 8 & $0.21 \pm 0.01$ & $2.02 \times 10^{5}$ & $3.54 \times 10^{4}$ & 0.107 \\
15 & 15 & $0.96 \pm 0.07$ & $2.60 \times 10^{5}$ & $1.11 \times 10^{4}$ & 0.275 \\
17 & 15 & $1.9 \pm 0.14$ & $1.15 \times 10^{5}$ & $2.85 \times 10^{4}$ & 0.198 \\
\hline
\end{tabular}

$\mathrm{nm}=$ not measured. Note that Station 7 uptake rate was measured from a surface pump sample, unlike the other stations, at which the water came from Go-flo bottles. See Figure 2.12.

\section{DISCUSSION}

\section{Utility of ${ }^{110}$ Cd Uptake Method}

The results of this study suggest that ${ }^{110} \mathrm{Cd}$ can be successfully used as a stable isotope tracer in marine environments. The ${ }^{110} \mathrm{Cd}$ uptake data suggest that at least a small fraction of ${ }^{110} \mathrm{Cd}$ is bioavailable when a $120 \mathrm{pM}$ spike is added to seawater and incubated for 24 hours, assuming that this method measures actual biological uptake into a cell.

\section{Cadmium Addition Experiments}

Cd ligand concentrations measured previously in the North Pacific had a concentration of $0.1 \mathrm{nM}$ (Bruland 1992); the only other Cd ligand data published are from off the coast of New Zealand, with ligand concentrations of 1-2 nM (Ellwood, 2004). Toxicity was thus expected to be observed at $5 \mathrm{nM}$ total $\mathrm{Cd}$ in experiments at all stations. Concentrations of total $\mathrm{Cd}$ added were chosen in search of a toxicity threshold. $\mathrm{Cd}$ addition experiments were run longer (multiple days) than uptake experiments (one day) to allow multiple day/night cycles and chance for growth of the bottled organisms over time.

Of the four stations at which $\mathrm{Cd}$ addition experiments were performed, Station 11 stands out in terms of having the highest initial chlorophyll $a$ concentration of the four stations by a factor of three. When considering this variability in terms of toxicity 
experiments, one may expect Station 11 to show a different result than the other three stations due a higher biomass taking up $\mathrm{Cd}$ and reducing the toxic effect. This however, is not the case- Station 11 shows a result different from Stations 14 and 17 (Figure 2.11). Results from Stations 14 and 17 show a reduction in chlorophyll $a$ with increasing Cd concentrations, a toxicity effect. Stations 11 and also 5 show relatively constant chlorophyll $a$ concentrations with increasing $\mathrm{Cd}$ concentrations, or at least no clear toxicity effect. If not chlorophyll $a$, perhaps the fact that Station 5 did not grow in the control relative to initial conditions explains the deviation from expectation, or perhaps the presence of Synechococcus prevented toxicity at this station.

Stations 5 and 14 had relatively similar initial conditions, although Station 14 grew and Station 15 did not. There are five noted differences: 1) Station 5 incubated for four days whereas the other stations incubated for three days, 2) Station 5 had about a factor of 1.5 less Prochlorococcus than Station 14, 3) Station 5 had a factor of 3.8 times more Synechococcus than Station 14, 4) Station 5 had undetectable Cd initially compared to $57 \mathrm{pM} \mathrm{Cd}^{2+}$ at Station 14, and 5) Station 5 water was collected from $15 \mathrm{~m}$ depth compared to $8 \mathrm{~m}$ for Station 14. Considering these possibilities, an incubation difference of 3 or 4 days (1) is probably not going to affect growth or no growth of an experiment. The collection of water from different depths (5) would arguably affect the microbial community composition initially and also the affinity of that community for a particular light environment. Bottles collected at 8 and $15 \mathrm{~m}$ were both incubated at the same percentage of ambient light in the on-deck incubator. The differing initial concentrations of total dissolved Cd (4) is probably not the reason because Stations 11 and 17 experiments showed growth and they also had initial concentrations that were below the detection limit. This leaves differences in cyanobacterial cell numbers ( 2 and 3 ).

A disparity in Synechococcus cell numbers is observed. Although cell numbers are higher at Station 11 than at Station 5 by a factor of $2.8,3.6 \times 10^{6}$ cells $\mathrm{mL}^{-1}$ and $1.3 \mathrm{x}$ $10^{6}$ cells $\mathrm{mL}^{-1}$ respectively, both Stations 5 and 11 have significantly higher cell numbers than either of Stations 14 and 17 (Figure 2.11). Station 5 and Station 11 have Synechococcus cell numbers greater than the oligotrophic stations by a factor of four and 
eight respectively. These data are consistent with the hypothesis that Synechococcus could be producing an organic ligand that binds the added $\mathrm{Cd}$, making it less bioavailable and thus preventing toxicity. Prochlorococcus dominates Synechococcus at Stations 14, 15 and 17, and Stations 14 and 17 do show a toxic effect suggesting that Prochlorococcus may be more sensitive to $\mathrm{Cd}$ concentrations and/or may not be contributing an organic ligand to bind $\mathrm{Cd}$. Speciation measurements would help by directly measuring the concentration of organic Cd-ligand complexes. Comparing inside and outside the dome toxicity results do suggest that the prevention of $\mathrm{Cd}$ toxicity to the phytoplankton community inside the dome is related to the increased presence of Synechococcus. One explanation is the production of organic ligands by Synechococcus that result in a greater degree of complexation of $\mathrm{Cd}$ relative to outside the dome and another is that more phytoplankton biomass reduces the dosage that each cell would receive. Both of these hypotheses are consistent with the data, although cannot be proven.

The combination of ${ }^{110} \mathrm{Cd}$ uptake experiments, $\mathrm{Cd}$ addition experiments, biological parameters, and natural total dissolved $\mathrm{Cd}$ measurements leaves us with some unanswered, tantalizing questions for the future: 1) What is the total microbial community at the different stations? 2) Is the Cd all taken up inside the cell? 3) Does a higher abundance of Synechococcus cells in the microbial community help prevent toxicity?

\section{Do kinetics affect uptake?}

The rate of Cd uptake can be considered in terms of Michaelis-Menten kinetics. Put simply, the total uptake rate is directly proportional to a kinetic rate constant, the bioavailable $\mathrm{Cd}$ and the quantity of microorganisms. Inorganic species of trace metals are typically bioavailable, as well as some organic forms. This means speciation is crucial when contemplating bioavailability. In this study, as the biological community and the ${ }^{110} \mathrm{Cd}$ uptake rate decreased, the total dissolved $\mathrm{Cd}$ (and thus probably the bioavailable $\mathrm{Cd}$ ) increased with depth. This suggests that uptake was related to the presence of organisms. The $\mathrm{Cd}$ addition experiments had a longer exposure to $\mathrm{Cd}$ at higher concentrations than uptake experiments. If cyanobacteria, as hypothesized, were 
producing ligands, stations with low cyanobacterial biomass (outside the dome) would likely be unable to produce ligands at a fast enough rate to bind $\mathrm{Cd}$ and reduce toxicity and so high Cd treatments at these stations would show toxic effects.

\section{Microbial community composition}

The entire microbial community composition is not known. Chlorophyll $a$ concentrations (a surrogate for total phytoplankton community) and size-fractionated chlorophyll $a$ concentrations (gives an idea of diatoms vs. the smaller picocyanobacteria) were estimated. The picophytoplankton, Prochlorococcus and Synechococcus, were counted using microscopy and flow cytometry. Other members of the microbial community such as diatoms, bacteria, and Archaea were not enumerated and could potentially be contributors to Cd cycling processes. A study by Franck et al., 2003 found that diatom abundances in the controls of three-day bottle incubation experiments in the Costa Rica Upwelling Dome were an order of magnitude lower than experiments conducted off the coast of central California. The total number of diatoms and flagellates in the controls were around 450 cells per mL (Franck et al., 2003). These low diatom abundances are consistent with the size-fractioned chlorophyll $a$ data in this study, which show that the $\leq 2 \mu \mathrm{m}$ size fraction at Stations 11 and 17 is the greatest component of total chlorophyll $a$ (Figures 2.4f, 2.6f; Tables I.2, I.3). Diatoms could be responsible for some of the Cd uptake, but our data do not allow us to determine this.

\section{Cadmium flux - The supply of upwelled cadmium approximately equals uptake rate}

The Cd supply at Station 11 from upwelling was estimated using a rate of $10^{-4} \mathrm{~cm}$ $\mathrm{s}^{-1}$ measured in this region by Wyrtki (1964), multiplied by the concentration difference between the total dissolved $\mathrm{Cd}$ measured at $100 \mathrm{~m}$ and the surface (Figure 2.13a). The estimated uptake flux of dissolved $\mathrm{Cd}$ was estimated by calculating a depth integrated dissolved $\mathrm{Cd}$ consumption using measured $\mathrm{Cd}$ uptake rates (Figure 2.13b). These two fluxes were each estimated to be on order of $5 \times 10^{4} \mathrm{pmol} \mathrm{m}^{-2} \mathrm{~d}^{-1}$. This implies that the upwelled $\mathrm{Cd}$ is taken up into the particulate fraction, depicted as a green circle in Figure 2.14. Fluxes out of the surface box would be advection and export to both the mid- and deep ocean. These processes were not investigated in this study. 


\section{a) Estimated upwelling flux}

$$
\begin{aligned}
\mathrm{X}_{\mathrm{Cd}}=\mathrm{w}\left(\mathrm{C}_{\mathrm{D}}-\mathrm{C}_{\mathrm{S}}\right) \\
=\left(10^{-4} \mathrm{~cm} \mathrm{~s}^{-1}\right)(551-0)\left(\mathrm{pmol} \mathrm{L}^{-1}\right) \\
\quad\left(8.64 \times 10^{4} \mathrm{~s} \mathrm{~d}^{-1}\right)\left(10^{4} \mathrm{~cm}^{2} \mathrm{~m}^{-2}\right) \\
\quad\left(10^{-3} \mathrm{~L} \mathrm{~mL}^{-1}\right)\left(\mathrm{mL} \mathrm{cm}^{-3}\right) \\
=5 \times 10^{4} \mathrm{pmol} \mathrm{m}^{-2} \mathrm{~d}^{-1} \\
\text { Upwellling }
\end{aligned}
$$

$\mathrm{X}_{\mathrm{Cd}}=$ supply of $\mathrm{Cd}$ from upwelling

$\mathrm{W}=$ upwelling (Wyrtki, 1964)

$\mathrm{C}_{\mathrm{D}}=$ dissolved $\mathrm{Cd}$ concentration deep

$\mathrm{C}_{\mathrm{S}}=$ dissolved Cd concentration surface

\section{b) Estimated uptake flux}

$$
\begin{aligned}
\mathrm{Z}_{\mathrm{Cd}}= & 0.5\left(\mathrm{U}_{\mathrm{s}}+\mathrm{U}_{\mathrm{D}}\right)\left(\mathrm{D}_{\mathrm{D}}-\mathrm{D}_{\mathrm{S}}\right) \quad \text { depth integrated } \\
= & (2800)\left(\mathrm{pmol} \mathrm{m}^{-3} \mathrm{~d}^{-1}\right)(8)(\mathrm{m}) \\
& +0.5(2800+1300)\left(\mathrm{pmol} \mathrm{m}^{-3} \mathrm{~d}^{-1}\right)(15-8)(\mathrm{m}) \\
& +0.5(1300+430)\left(\mathrm{pmol} \mathrm{m}^{-3} \mathrm{~d}^{-1}\right)(30-15)(\mathrm{m}) \\
& +0.5(430+0)\left(\mathrm{pmol} \mathrm{m}^{-3} \mathrm{~d}^{-1}\right)(50-30)(\mathrm{m}) \\
= & 5 \times 10^{4} \mathrm{pmol} \mathrm{m}^{-2} \mathrm{~d}^{-1}
\end{aligned}
$$

$$
\begin{aligned}
& \text { Uptake } \\
& \begin{array}{ll}
\mathrm{Z}_{\mathrm{Cd}} & =\text { consumption of Cd by uptake } \\
\mathrm{U} & =\text { uptake rate } \\
\mathrm{U}_{\mathrm{S}} & =\text { uptake rate, shallow } \\
\mathrm{U}_{\mathrm{D}} & =\text { uptake rate, deep } \\
\mathrm{D}_{\mathrm{S}} & =\text { depth, shallow } \\
\mathrm{D}_{\mathrm{D}} & =\text { depth, deep }
\end{array}
\end{aligned}
$$

Figure 2.13. Equations, calculations and variables for estimating a) upwelled and b) taken up cadmium fluxes at Station 11, inside the dome. Assuming upwelling from $100 \mathrm{~m}$ and depth integrated upwelling calculated from the surface $100 \mathrm{~m}$.

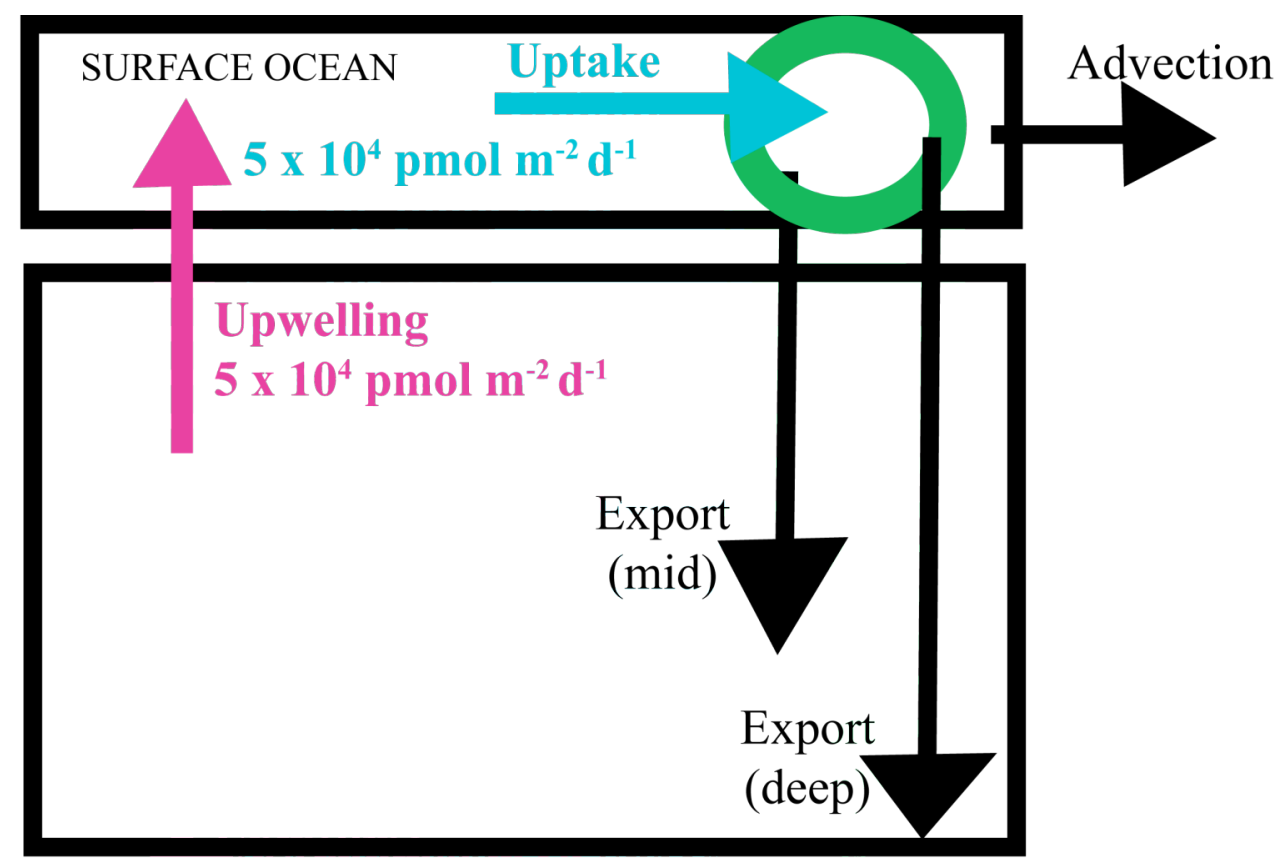

Figure 2.14: Two-box model of Cd biogeochemistry in the Costa Rica upwelling dome. Calculated upwelling flux of $\mathrm{Cd}$ is estimated to be approximately equal to that of $\mathrm{Cd}$ that is taken up into the particulate fraction. Pink arrow - upwelling flux of Cd. Blue arrow - uptake flux of Cd into particulate fraction. Green circle - particulate fraction in the surface ocean. Black arrows - fluxes out of the surface ocean and particulate fraction not estimated in this study - advection and export both mid and deep. 


\section{CONCLUSIONS}

In conclusion, results of 24-hour uptake studies suggest that ${ }^{110} \mathrm{Cd}$ as a spike can successfully be used as an intermediate abundance, stable isotope tracer. An increase in particulate ${ }^{110} \mathrm{Cd}$ concentration in spiked samples relative to preexisting $\mathrm{Cd}$ and a decrease in ${ }^{114} \mathrm{Cd} /{ }^{110} \mathrm{Cd}$ and ${ }^{111} \mathrm{Cd} /{ }^{110} \mathrm{Cd}$ isotope ratios indicated the uptake of ${ }^{110} \mathrm{Cd}$ in waters shallower than $40 \mathrm{~m}$. The uptake rate of $\mathrm{Cd}$ correlated positively with chlorophyll $a$ concentrations. Results of time course ${ }^{110} \mathrm{Cd}$ uptake studies indicate uptake with time in spiked samples because the ${ }^{110} \mathrm{Cd}$ concentrations increase and the ${ }^{114} \mathrm{Cd} /{ }^{110} \mathrm{Cd}$ and ${ }^{111} \mathrm{Cd} /{ }^{110} \mathrm{Cd}$ isotope ratios decrease with time. Linear regression analyses of concentration versus time in these studies also suggest that a 24-hour time point is an adequate measurement of uptake and demonstrate that considering preexisting particulate $\mathrm{Cd}$ in the form of a particulate blank in high biomass regions is necessary. Depth integrated uptake estimates of total $\mathrm{Cd}$ consumption compared to estimated upwelling flux of Cd suggest that the dissolved upwelled $\mathrm{Cd}$ in the dome is taken up into the particulate fraction. Cd addition experiments suggest that higher cell numbers of Synechococcus are related to prevention of Cd toxicity in the dome, but outside the dome with lower cell numbers of Synechococcus, in the cyanobacterial community dominated by Prochlorococcus, toxic effects are observed. This suggests that the greater biomass and microbial community prevent toxicity of added $\mathrm{Cd}$, perhaps by diluting the $\mathrm{Cd}$ throughout the community in the dome. Outside the dome, Prochlorococcus is the numerically dominant member of the cyanobacterial community and may be more sensitive to $\mathrm{Cd}$ and the $\mathrm{Cd}$ is diluted less over the overall community. Electrochemical measurements of total dissolved $\mathrm{Cd}$ demonstrate a nutrient-like profile and correlation with nutrients, as expected. Together, these experiments suggest that uptake of Cd into the microbial loop occurs in the upper water column both in and out of the Costa Rica Dome, but show that $\mathrm{Cd}$ toxicity is not induced within the dome presumably due to a greater amount of biomass in that region and less sensitivity of that biomass to $\mathrm{Cd}$. 


\section{Acknowledgements}

I would like to thank the captain, crew, and science party of the R/V Knorr 185-2. Thank you to Abigail Noble for total dissolved Cd measurements, Anne Thompson for Synechococcus and Prochlorococcus cell numbers, Lisa Moore and lab for size fractionated chlorophyll measurements, Eric Webb for shipboard cell numbers, Nathan Ahlgren for figure of stations, Matthew Hurst and Seth John for discussion and Dave Schneider for assistance on the ICP-MS. Thanks to members of the Saito and Moffett labs - Jim Moffett, Andrew Rose, Chad Hammerschmidt, Rachel Wisniewski (now Jakuba), Tyler Goepfert, Dreux Chappell, Michelle Bringer and Erin Bertrand. Thank you to Ed Boyle, Carl Lamborg and Ben Van Mooy for helpful review. This work was funded by NSF Chemical Oceanography (OCE-0327225 and OCE-0452883) and supported by a MIT/WHOI Joint Program Summer Research Fellowship and MIT Presidential Scholar Fellowship. 


\section{References}

Boyle, E.A., Sclater, F. and Edmond, J.M. 1976. On the marine geochemistry of cadmium. Nature 263: 42-44.

Boyle, E.A. 1988. Cadmium: chemical tracer of deepwater paleoceanography. Paleoceanography 3: 471-489.

Broenkow, W. W. 1965. The distribution of nutrients in the Costa Rica Dome in the Eastern Tropical Pacific Ocean. Limnology and Oceanography 10(1): 40-52.

Bruland, K.W., Franks, R.P., Knauer, G.A., and Martin, J.H. 1979. Sampling and analytical methods for the determination of copper, cadmium, zinc, and nickel at the nanogram per liter level in sea water. Analytica Chimica Acta 105: 233-245.

Bruland, K. W. 1980. Oceanographic distributions of cadmium, zinc, nickel, and copper in the North Pacific. Earth and Planetary Science Letters 47: 176-198.

Bruland, K.W. 1992. Complexation of cadmium by natural organic ligands in the central North Pacific. Limnology and Oceanography 37(5): 1008-1017.

Calabrese, E.J. 2005. Toxicological awakenings: the rebirth of hormesis as a central pillar of toxicology. Toxicology and Applied Pharmacology 204: 1- 8.

Croteau, M.N., Luoma, S.N. and Pellet, B. 2007. Determining metal assimilation efficiency in aquatic invertebrates using enriched stable metal isotope tracers. Aquatic Toxicology 83: 116-125.

Cullen, J. T., Lane, T. W., Morel, F. M. M. and Sherrell, R. M. 1999. Modulation of cadmium utilization in phytoplankton by seawater concentration. Nature 402: 165-167.

Cullen, J.T. and Sherrell, R.M. 1999. Techniques for determination of trace metals in small samples of size-fractioned particulate matter: phytoplankton metals off central California. Marine Chemistry 67: 233-247.

Elderfield, H. and Rickaby, R.E.M. 2000. Oceanic Cd/P ratio and nutrient utilization in the glacial Southern Ocean. Nature 405: 305-310.

Ellwood, M.J. and Hunter, K.A. 1999. The determination of the $\mathrm{Zn} / \mathrm{Si}$ ratio in diatom opal: a method for the separation, cleaning and dissolution of diatoms. Marine Chemistry 66: $149-160$. 
Ellwood, M.J. and Hunter, K.A. 2000. The incorporation of zinc and iron into the frustule of the marine diatom Thalassoiosira pseudonana. Limnology and Oceanography 45(7): $1517-1524$.

Ellwood, M.J. 2004. Zinc and cadmium speciation in subantarctic waters east of New Zealand. Marine Chemistry 87: 37-58.

Echeveste, P., Agusti, S. and Dachs, J. 2010. Cell size dependent toxicity thresholds of polycyclic aromatic hydrocarbons to natural and cultured phytoplankton populations. Environmental Pollution 158(1): 299-307.

Fiedler, P.C. 2002. The annual cycle and biological effects of the Costa Rica Dome. Deep-Sea Research I 49: 321-338.

Fischer, E. and van den Berg, C.M.G. 1999. Anodic stripping voltammetry of lead and cadmium using a mercury film electrode and thiocyanate. Analytica Chimica Acta 385: 273-280.

Franck, V.M., Bruland, K.W., Hutchins, D. A. and Brzezinski, M.A. 2003. Iron and zinc effects on silicic acid and nitrate uptake kinetics in three high-nutrient, low-chlorophyll (HNLC) regions. Marine Ecolgy Progress Series 252: 15-33.

Gee, A.K. and Bruland, K.W. 2002. Tracing Ni, Cu, and Zn kinetics and equilibrium partitioning between dissolved and particulate phases in South San Francisco Bay, California, using stable isotopes and high-resolution inductively coupled plasma mass spectrometry, Geochimica et Cosmochimica Acta 66: 3063-3083.

Hofmann, E.E., Busalacchi, A.J. and O'Brien, J.J. 1981. Wind Generation of the Costa Rica Dome. Science 214: 552-554.

Hunter, K.A., Kim, J.P. and Croot, P.L.1997. Biological roles of trace metals in natural waters. Environmental Monitoring and Assessment 44: 103-147.

Hurst, M.P. and Bruland, K.W. 2007. An investigation into the exchange of iron and zinc between soluble, colloidal, and particulate size-fractions in shelf waters using lowabundance isotopes as tracers in shipboard incubation experiments. Marine Chemistry 103: 211-226.

Hurst, M.P. and Bruland, K.W. 2008. The effects of the San Francisco Bay plume on trace metal nutrient and nutrient distributions in the Gulf of the Farallones. Geochimica et Cosmochimica Acta 72: 395-411. 
Hutchins, D.A., Wang, W.X., Schmidt, M.A. and Fisher, N.S 1999. Dual-labeling techniques for trace metal biogeochemical investigations in aquatic plankton communities. Aquatic Microbial Ecology 19: 129-138.

Hutchins, D.A., Witter, A. E., Butler, A. and Luther, G.W. 1999. Competition among marine phytoplankton for different chelated iron species. Nature 400: 858-861.

JGOFS (Joint Global Ocean Flux Study) Protocols (1994) Protocols for the Joint Global Ocean Flux Study (JGOFS). Core Meas, Manual Guides 29: 119-122.

Li, W.K.W., Subba Rao, D.V., Harrison, W.G., Smith, J.C., Cullen, J.J., Irwin, B. and Platt, T. 1983. Autotrophic picoplankton in the tropical ocean. Science 219: 292-295.

Maldonado, M. T. and Price, N. M. 1999. Utilization of iron bound to strong organic ligands by plankton communities in the subarctic Pacific Ocean. Deep Sea Research Part II 46: 2447-2473.

Mann, E. L., Ahlgren, N., Moffett, J.W. and Chisholm, S. W. 2002. Copper toxicity and cyanobacteria ecology in the Sargasso Sea. Limnology and Oceanography 47: 976-988.

Morel, F.M.M., Milligan, A.J. and Saito, M.A. 2003. Marine bioinorganic chemistry: The role of trace metals in the oceanic cycles of major nutrients. Treatise on Geochemistry Volume 6 The Oceans and Marine Geochemistry. eds. Henry Elderfield. H.D. Holland and K.K. Turekian. 6.05: 113-143.

Morel, F.M.M., Reinfelder, J.R., Roberts, S.B., Chamberlain, C.P., Lee, J.G. and Yee, D. 1994. Zinc and carbon co-limitation of marine phytoplankton. Nature 369: 740-742.

Pickhardt, P.C., Folt, C.L., Chen, C.Y., Klaue, B. and Blum, J.D. 2002. Algal blooms reduce the uptake of toxic methylmercury in freshwater food webs. Proceedings of the National Academy of Sciences of the United States of America: 99: 4419-4423.

Quigg, A., Reinfelder, J. R. and Fisher, N.S. 2006. Copper uptake kinetics in diverse marine phytoplankton. Limnology and Oceanography 51: 893-899.

Ripperger, S. and Rehkämper, M. 2007. Precise determination of cadmium isotope fractionation in seawater by double spike MC-ICPMS. Geochimica et Cosmochimica Acta 71: 631-642.

Saito, M.A., Rocap, G. and Moffett, J.W. 2005. Production of cobalt binding ligands in a Synechococcus feature at the Costa Rica upwelling dome. Limnology and Oceanography 50(1): 279-290. 
Semeniuk, D.M., Cullen, J.T., Johnson, W.K., Gagnon, K., Ruth, T.J. and Maldonado, M.T. 2009. Plankton copper requirements and uptake in the subarctic Northeast Pacific Ocean. Deep Sea Res. I 56: 1130-1142.

Sunda, W.G. 1988. Trace metal interactions with marine phytoplankton. Biology and Oceanography 6: 411-442.

Sunda, W.G. and Huntsman, S.A. 1995. Iron uptake and growth limitation in oceanic and coastal phytoplankton. Marine Chemistry 50: 189-206.

Sunda, W.G. and Huntsman, S.A. 2000. Effect of Zn, Mn, and Fe on Cd accumulation in phytoplankton: Implications for oceanic Cd cycling. Limnology and Oceanography 45(7): 1501-1516.

Thompson, A.W. 2009. Iron and Prochlorococcus. Ph. D. Thesis. Joint Program in Biological Oceanography, Massachusetts Institute of Technology, Dept. of Biology and the Woods Hole Oceanographic Institution.

Wyrtki, K. 1964. Upwelling in the Costa Rica Dome. U.S. Fish Wildlife Service Fishery Bulletin 63: 355-372. 


\title{
Chapter 3
}

\section{Zinc-deprived coastal Synechococcus WH5701 show physiological and strong proteomic response to chronic cadmium stress}

\begin{abstract}
Synechococcus sp. WH 5701 is a euryhaline, phycocyanin-rich, phycoerythrin lacking marine cyanobacterium. It was isolated originally from Long Island Sound, a coastal environment with high trace metal availability and variable irradiance due to mixing. To test the response of this organism to free cadmium $(\mathrm{Cd})$, generally considered a toxin with one known nutritive use in a marine diatom, cultures were exposed to 4.4 and $44 \mathrm{pM}$ free $\mathrm{Cd}^{2+}$. Physiological measurements of cell counts, chlorophyll $a$ and phycoerythrin fluorescence throughout growth, stationary and death phases show $\mathrm{Cd}$ had little effect on growth rates, but higher $\mathrm{Cd}$ concentrations caused an increase in mortality rates and maximum chlorophyll $a$ fluorescence. Global proteomic analysis of relative protein abundance at five time points throughout the entire growth curve revealed a greater abundance of ribosomal and photosystem I proteins during exponential growth relative to stationary phase. Cd caused a two-fold or more increase in relative abundance of ribosomal proteins, arylsulfatases, cysteine metabolism and chlorophyll $a$ biosynthesis proteins, among others, and a two-fold or more decrease in the relative abundance of core photosystem I, carboxysome-associated and hypothetical proteins during exponential growth, suggesting chronic $\mathrm{Cd}$ exposure had a great metabolic impact.
\end{abstract}




\section{INTRODUCTION}

Marine cyanobacteria play an important role in primary productivity and the evolution of the environment on earth as discussed on pages 13-14 of Chapter 1. Cadmium $(\mathrm{Cd})$ and zinc $(\mathrm{Zn})$ are trace elements with nutrient distributions in the ocean (discussed on pages 15-16 of Chapter 1) and have shown to have interactions in culture (discussed on pages 18-20 of Chapter 1).

Synechococcus WH5701 is a marine subcluster 5.2, MC-B (Scanlan, 2003) cyanobacteria, originally isolated from Long Island Sound. It is euryhaline, phycocyaninrich, and lacks phycoerythrin II. Not much culture work exists in the literature concerning WH5701 thus far and although the MC-A group is thought to be the dominant Synechococcus group within the euphotic zone of open ocean and coastal waters (Fuller et al., 2003 and references therein), recent studies on the diversity of Synechococcus strains isolated from the Baltic Sea show picocyanobacteria, very similar to WH5701 by 16S rRNA-ITS (Haverkamp et al., 2009). WH5701 is a good coastal environmental model because of the original isolation location and it may have arguably already been affected by increased anthropogenic inputs before isolation.

Cells are known to take up $\mathrm{Cd}$ even though it is not required for growth. If cells do not require $\mathrm{Cd}$, the destination of $\mathrm{Cd}$ inside a cell is of interest. Metals are tightly regulated in cells and metal sensing is important (Waldron et al., 2009). Cd can interfere with the metals calcium, zinc, and iron (Martelli et al., 2006). In diatoms, Cd can be taken up through manganese and zinc transporters (Sunda and Huntsman, 2000). Experimental support in animal cells for Cd substituting for native metals is scarce at best, despite this being often proposed as the leading mechanism of Cd toxicity (Martelli et al, 2006). Mechanisms of toxicity in photosynthetic organisms range from $\mathrm{Cd}$ replacing magnesium in chlorophyll in plants (Küpper et al., 1998) to $\mathrm{Cd}^{2+}$ binding reaction centers in Rhodobacter sphaeroides thereby reducing rates of electron transfer from photosystem II to $\mathrm{Q}_{\mathrm{B}}$ (Okamura et al., 2000 and reference therein).

Metallothioneins and low molecular weight thiols are a possibility for intracellular Zn storage and Cd detoxification are discussed on pages 20-24 of Chapter 1. Low 
molecular weight thiols have been produced by cultures of Emiliania huxleyi upon exposure to cadmium, zinc, and copper (Dupont and Ahner, 2005) and measured in the Galveston Bay (Tang et al., 2000) and the subarctic Pacific Ocean (Dupont and Moffett et al., 2006). The possibility of low molecular weight thiols as a response to $\mathrm{Cd}$ is considered in this chapter

In this chapter, the physiological and proteomic responses of the coastal Synechococcus WH5701 to chronic Cd stress under Zn deficient conditions will be presented, a condition not often encountered in the environment due to the greater relative abundance of $\mathrm{Zn}$. The biological function of an element can only be assessed properly against a background of deficiency state (Vallee and Ulmer, 1972). It is notoriously difficult to limit cyanobacteria for $\mathrm{Zn}$. If $\mathrm{Cd}$ is interfering with $\mathrm{Zn}$ metabolism, these experimental conditions would be likely to reveal that situation. Our physiological and proteomic data show that this coastal cyanobacterium does not appear

much affected by the addition of $\mathrm{Cd}^{2+}$ during growth phase due to the similar growth rates of the $\mathrm{Cd}$ treatments to the no added $\mathrm{Cd}$, but the change in relative abundance of proteins show that the exposure to $\mathrm{Cd}$ has a major impact on photosynthesis, protein synthesis, carbon fixation, and sulfur metabolism. The physiological effects of $\mathrm{Cd}$ surface during stationary phase with an increase in maximum chlorophyll $a$ fluorescence with the $\mathrm{Cd}$ treatments relative to the control and faster mortality rates. This paper also provides a comprehensive view of the change in relative protein abundance throughout the growth curve of Synechococcus WH5701.

\section{METHODS}

\section{Culturing and protein extraction}

Axenic cultures of Synechococcus sp. WH 5701 obtained from J. Waterbury (Woods Hole Oceanographic Institution) were maintained in a PRO-TM media (modified from Saito et al., 2002) made with $75 \%$ oligotrophic seawater obtained from the oligotrophic South Atlantic ocean and prepared by microwave sterilization and the addition of chelexed and filtered nutrients $\left(1.1 \mathrm{mM} \mathrm{NO}_{3}{ }^{-}\right.$and $\left.65 \mu \mathrm{M} \mathrm{PO}_{4}{ }^{3-}\right)$ and EDTA- 
complexed metals (22.2 $\mu \mathrm{M}$ EDTA, $171 \mathrm{nM} \mathrm{MnCl}$, $5.7 \mathrm{nM} \mathrm{Na} 2 \mathrm{MoO}_{4}, 19 \mathrm{nM} \mathrm{Na}_{2} \mathrm{SeO}_{3}$, $2.22 \mu \mathrm{M} \mathrm{FeCl}_{3}, 19 \mathrm{nM} \mathrm{CoCl}_{2}, 19 \mathrm{nM} \mathrm{NiCl}_{2}$ ). Chronic $\mathrm{Cd}$ treatments had $\mathrm{Cd}$ added to a total concentration of 10 and $100 \mathrm{nM} \mathrm{CdCl}_{2}$, with the free concentrations estimated to be $4.4 \mathrm{pM} \mathrm{Cd}^{2+}$ and $44 \mathrm{pM} \mathrm{Cd}^{2+}$, respectively, using thermodynamic data from EDTA stability constant data from Martell and Smith, 1993. The ratio of $\mathrm{Cd}^{2+}: \mathrm{Cd}_{\text {TOT }}$ was calculated to be 1:2267. This ratio in a PRO-TM media with $11.7 \mu \mathrm{M}$ EDTA (Saito et al., 2002) was calculated to be 1:1216 (Saito et al., unpublished data) and 1:6026 in a media with $100 \mu \mathrm{M}$ EDTA (Sunda and Huntsman, 1998). The ratio of $\mathrm{Cd}^{2+}$ to the total of major inorganic species in a PRO-TM media with 11.7 $\mu$ M EDTA (Saito et al., 2002) was calculated to be 1:36 (Saito et al., unpublished data). The blank of the medium was not determined. Previous researchers doing similar trace metal culture studies have assumed background metal concentrations of 100 pM for cobalt (Sunda and Huntsman, 1995; Sunda and Huntsman, 1998; Saito et al., 2002), 900 pM for Zn (Sunda and Huntsman, 1995; Sunda and Huntsman, 1998) and 100 pM for cadmium (Sunda and Huntsman, 1998). Cultures were grown in either $28 \mathrm{~mL}$ polycarbonate tubes or $1 \mathrm{~L}$ polycarbonate bottles under $30 \mu \mathrm{mol}$ photons ( $\mu$ Einstein) $\mathrm{m}^{-2} \mathrm{~s}^{-1}$ continuous white light. All plasticware was soaked for two days in a detergent, then two weeks in $10 \% \mathrm{HCl}$ (Fisher, trace metal grade), rinsed with $\mathrm{pH} 2 \mathrm{HCl}$ and then microwave sterilized. Culture growth was monitored by a combination of chlorophyll $a$ and phycoerythrin fluorescence and cell counting by microscopy. Growth rates were calculated from the natural log of in vivo relative chlorophyll $a$ fluorescence $(\mathrm{n}=5)$. Mortality rates were calculated from the natural $\log$ of in vivo relative chlorophyll $a$ fluorescence $(\mathrm{n} \geq 4)$. For protein samples, approximately $150 \mathrm{~mL}$ of culture were harvested by centrifugation in a Beckman J2-21M centrifuge at $18,566 \mathrm{~g}$ for $30 \mathrm{~min}$ at $4^{\circ} \mathrm{C}$, decanted, transferred into a microtube and centrifuged again at 14,000 g for $15 \mathrm{~min}$ at room temperature, decanted, and frozen at $80^{\circ} \mathrm{C}$.

Protein was extracted from the digestion of frozen whole cell pellets. Sample tubes were kept on ice throughout the extraction process, unless otherwise noted. Cell pellets were resuspended in $500 \mu \mathrm{L}$ of $100 \mu \mathrm{M}$ ammonium bicarbonate buffer solution, 
$\mathrm{pH}$ 8.0, (AMBIC) ice cold. Using a Branson sonifier 450, samples were sonicated on ice for $4 \mathrm{~min}$ at $70 \%$ duty with an output of 3 . After a 5 min pause, samples were sonicated for another $4 \mathrm{~min}$. Samples were centrifuged at $4^{\circ} \mathrm{C}$ at $14,000 \mathrm{~g}$ for $35 \mathrm{~min}$. $200 \mu \mathrm{L}$ of supernatant was precipitated overnight with $800 \mu \mathrm{L}$ of $-20^{\circ} \mathrm{C}$ acetone.

Acetone-precipitated samples were centrifuged at $4^{\circ} \mathrm{C}$ at $14,000 \mathrm{~g}$ for $30 \mathrm{~min}$ and decanted. One hundred $\mu \mathrm{L}$ of freshly made $7.5 \mathrm{M}$ urea in AMBIC and $25 \mu \mathrm{L}$ of AMBIC were added to the acetone-precipitated pellet. Samples were incubated for approximately $15 \mathrm{~min}$ at room temperature with periodic vortexing then resuspended by incubation for 5 min at $95^{\circ} \mathrm{C}$. A $100 \mu \mathrm{L}$ aliquot was removed and $5 \mu \mathrm{L}$ of $200 \mathrm{mM}$ dithiothreitol (DTT) in AMBIC was added and incubated for $1 \mathrm{hr}$ at $56^{\circ} \mathrm{C}$, shaken at $400 \mathrm{rpm}$. The sample was vortexed and centrifuged at 14,000 g for $2 \mathrm{~min}$. Twenty $\mu \mathrm{L}$ of $200 \mathrm{mM}$ iodacetamide in AMBIC was added and incubated for $1 \mathrm{hr}$ at room temperature in the dark, shaken at $400 \mathrm{rpm} .20 \mu \mathrm{L}$ of $200 \mathrm{mM}$ DTT in AMBIC was added, mixed, centrifuged for $2 \mathrm{~min}$ as above, and incubated for $1 \mathrm{hr}$ at room temperature, shaken at 400 rpm. After incubation, the sample was centrifuged for $2 \mathrm{~min}$ as above. Total protein yield was assayed using the Biorad DC Protein Assay. Trypsin (Promega) was reconstituted in $500 \mu \mathrm{L}$ of $50 \mathrm{mM}$ acetic acid and added in a trypsin to protein ratio of 1:50. The sample was mixed, vortexed, centrifuged for $2 \mathrm{~min}$ as above, and incubated for approximately 16 hours at $37^{\circ} \mathrm{C}$, shaken at $400 \mathrm{rpm}$.

After trypsin digestion, the sample was vortexed, centrifuged for $2 \mathrm{~min}$, and 20 $\mu \mathrm{L}$ of LC-MS grade glacial acetic acid added. Sample was evaporated by speed vacuum for approximately $3 \mathrm{~h}$ to a final volume of approximately $600 \mu \mathrm{L}$. Sample was centrifuged at 14,000 $\mathrm{g}$ for 30 minutes and the supernatants collected. Four $\mu \mathrm{g}$ of protein was added per injection.

\section{Liquid Chromatography-Mass Spectrometry (LC-MS)}

The digests were analyzed by LC-MS using a Paradigm MS4 HPLC system with reverse phase chromatography, Thermo LTQ ion trap mass spectrometer and Microhm ADVANCE source $(2 \mu \mathrm{L} / \mathrm{min}$ flow rate, $345 \mathrm{~min}$ runs, $150 \mathrm{~mm}$ column, $40 \mu \mathrm{L}$ injections, water ACN gradient). Each digest was injected three times for a total of 45 
mass spectrometry runs. Mass spectra were processed by SEQUEST and PeptideProphet with a fragment tolerance of 1.0 Da (monoisotopic), parent tolerance of 2.0 Da (monoisotopic), fixed modification of +57 on $\mathrm{C}$ (carbamidomethyl), variable modification of +16 on $\mathrm{M}$ (oxidation) and a maximum of 2 missed trypsin cleavages using a database including reversed proteins and common contaminants. Spectral counts of 45 files were compiled in Scaffold 3 with a peptide false discovery rate of $1.7 \%$, minimum peptide and protein confidence levels of 95 and $99 \%$, respectively with a minimum of 2 peptides. (Peng et al., 2003; Zhang et al., 2006). A spectral count is the number of times a particular peptide from a protein is sampled during an MS/MS experiment and is indicative of protein relative abundance. Graphs are made with spectral counts of proteins that have a minimum of four identified peptides and the function assigned by using the Kyoto Encyclopedia of Genes and Genomes (KEGG). Tables are made by ratios of average spectral counts with at least one value greater than or equal to 5 spectral counts.

\section{RESULTS AND DISCUSSION}

This section begins with physiological and then moves to proteomic data. The physiological data from three experiments is presented and discussed $(28 \mathrm{~mL}$ reconnaissance experiment, $1 \mathrm{~L}$ experiment with protein data, and $28 \mathrm{~mL}$ repeat and addition of $\mathrm{Zn}$ experiment). Any low molecular weight thiol data discussed were from a fourth experiment in $500 \mathrm{~mL}$ cultures performed concurrently with the $28 \mathrm{~mL}$ repeat and $\mathrm{Zn}$ addition experiment. The complex proteomic dataset is presented in terms of cluster analysis, then pairwise-comparison of $\mathrm{Cd}$ treatments to the control at each timepoint throughout the experiment and ties the protein data back to the physiological observations by discussion of functional groups of proteins affected by $\mathrm{Cd}$. 


\section{Physiological Data}

The growth of WH5701 under chronic Cd concentrations ranging from no added $\mathrm{Cd}^{2+}$ to $44 \mathrm{pM}$ free $\mathrm{Cd}^{2+}$ in duplicate $28 \mathrm{~mL}$ tubes as monitored by the relative fluorescence of chlorophyll $a$ in vivo measured over approximately 30 days yielded three salient observations (Figure 3.1). First, despite differing $\mathrm{Cd}$ concentrations, growth rates of all treatments were similar throughout five days of exponential growth (Figures 3.1, 3.2a). Growth rates $(n=5)$ were calculated from the average of duplicate tubes. Second, the addition of $\mathrm{Cd}$ resulted in an increase in the maximal chlorophyll $a$ fluorescence that was the most pronounced in the highest $\mathrm{Cd}$ addition, $44 \mathrm{pM} \mathrm{Cd}^{2+}$ (Figures 3.1, 3.2b). And third, the addition of $\mathrm{Cd}$ increased the mortality rates of the $4.4(\mathrm{n}=14)$ and $44 \mathrm{pM}$ $\mathrm{Cd}^{2+}(\mathrm{n}=9)$ relative to the control $(\mathrm{n}=16)$ by a factor of 1.8 and four, respectively (Figures 3.1, 3.2c). Mortality rates once the cultures began to die were 1.3 and 2.5 times greater than the control $(\mathrm{n}=8)$ for $4.4(\mathrm{n}=11)$ and $44 \mathrm{pM} \mathrm{Cd}^{2+}(\mathrm{n}=9)$ treatments, respectively (Figure 3.2d). In a repeat experiment in $28 \mathrm{~mL}$ tubes, extended to include the presence of tens of picomolar $\mathrm{Zn}^{2+}$ in the media, growth rates were again similar, however the addition of $\mathrm{Cd}$ did not result in an increase in chlorophyll $a$ fluorescence or increased mortality rates (Figure 3.3).

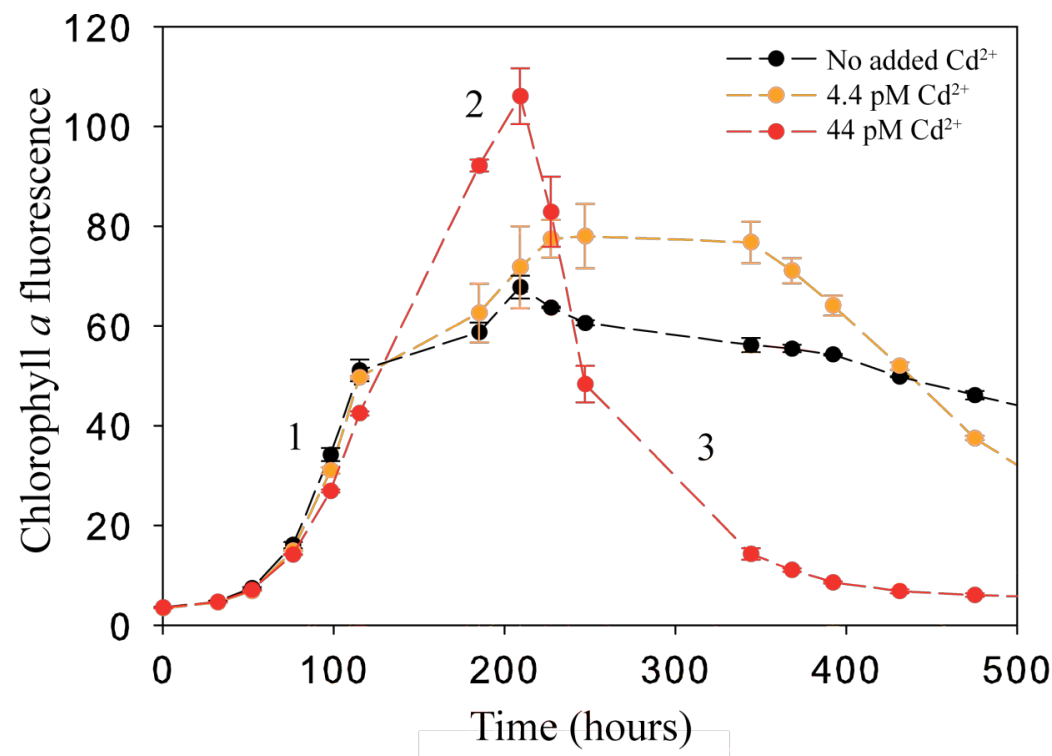

Figure 3.1: Growth of WH5701 under chronic $\mathrm{Cd}^{2+}$ stress as measured by relative chlorophyll $a$ fluorescence, points are averages of duplicates. This was a reconaissance experiment in 28 $\mathrm{mL}$ tubes. Error bars represent range of duplicate measurements. Note 1) similar growth rate through exponential phase 2) increased maximum chlorophyll $a$ fluorescence with added $\mathrm{Cd}^{2+}$ and 3 ) increased mortality rates with added $\mathrm{Cd}^{2+}$. These are physiological effects. 


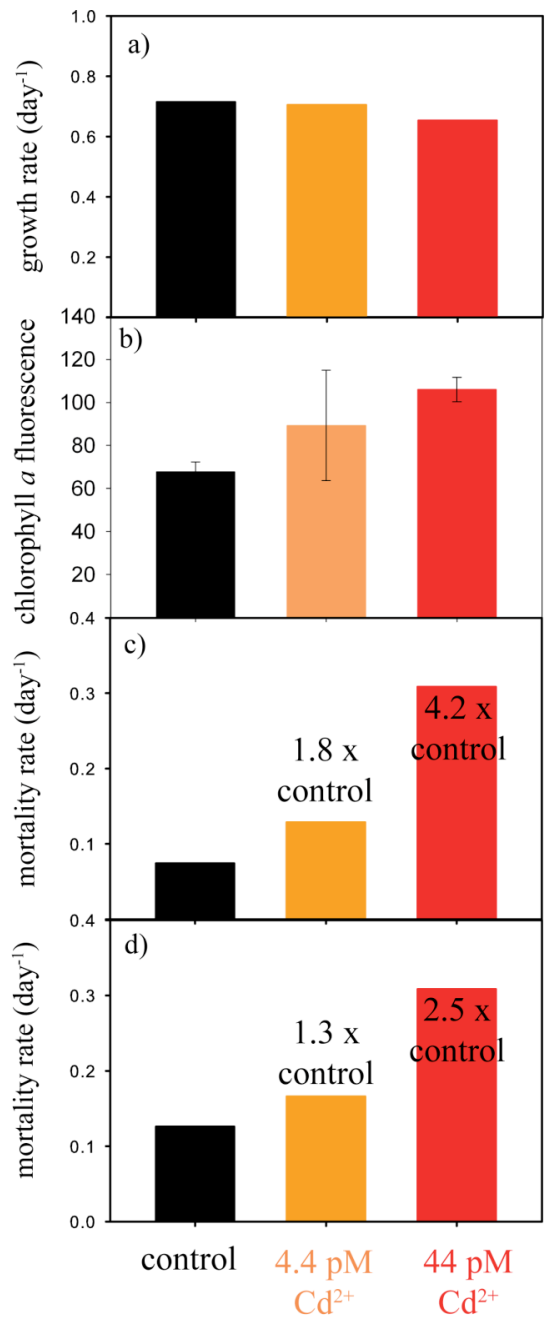

Figure 3.2: a) Growth rates, b) maximum chlorophyll $a$ fluorescence, c) mortality rates and d) mortality rates once dying calculated from Figure 3.1. Error bars represent range of duplicate measurements. 


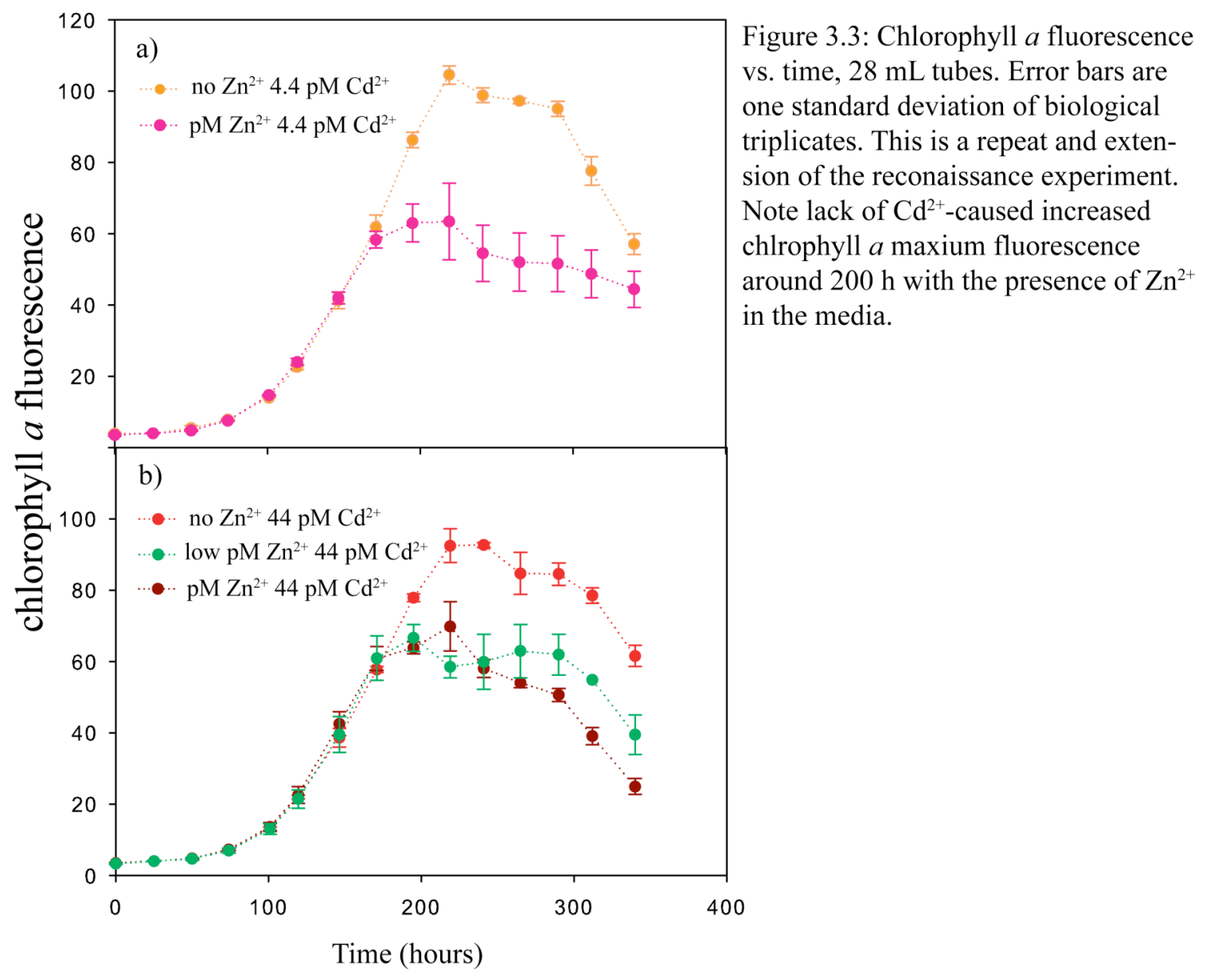

Similar physiological results were obtained upon repetition of the reconnaissance experiment with singlicate $1 \mathrm{~L}$ cultures, with cell numbers monitored and samples collected for global proteomic analysis at five time points throughout the growth curve (Figure 3.4). Again, growth rates among the three treatments were similar when calculated using chlorophyll $a$ and phycoerythrin (data not shown). According to cell number, the cells entered stationary phase around 120 hours. Cell numbers revealed similar growth rates and showed that the loss of chlorophyll $a$ fluorescence during death phase was due to a decrease in cell numbers (compare Figure 3.4a, b and c). The chlorophyll $a$ /phycoerythrin fluorescence ratio increases steadily through growth and early stationary phase across all treatments. The $\mathrm{Cd}$ treatments continue to increase through stationary phase, however, while the control does not. Instead, the $\mathrm{Cd}$ treatments diverge from each other and the control (Figure 3.4d). 

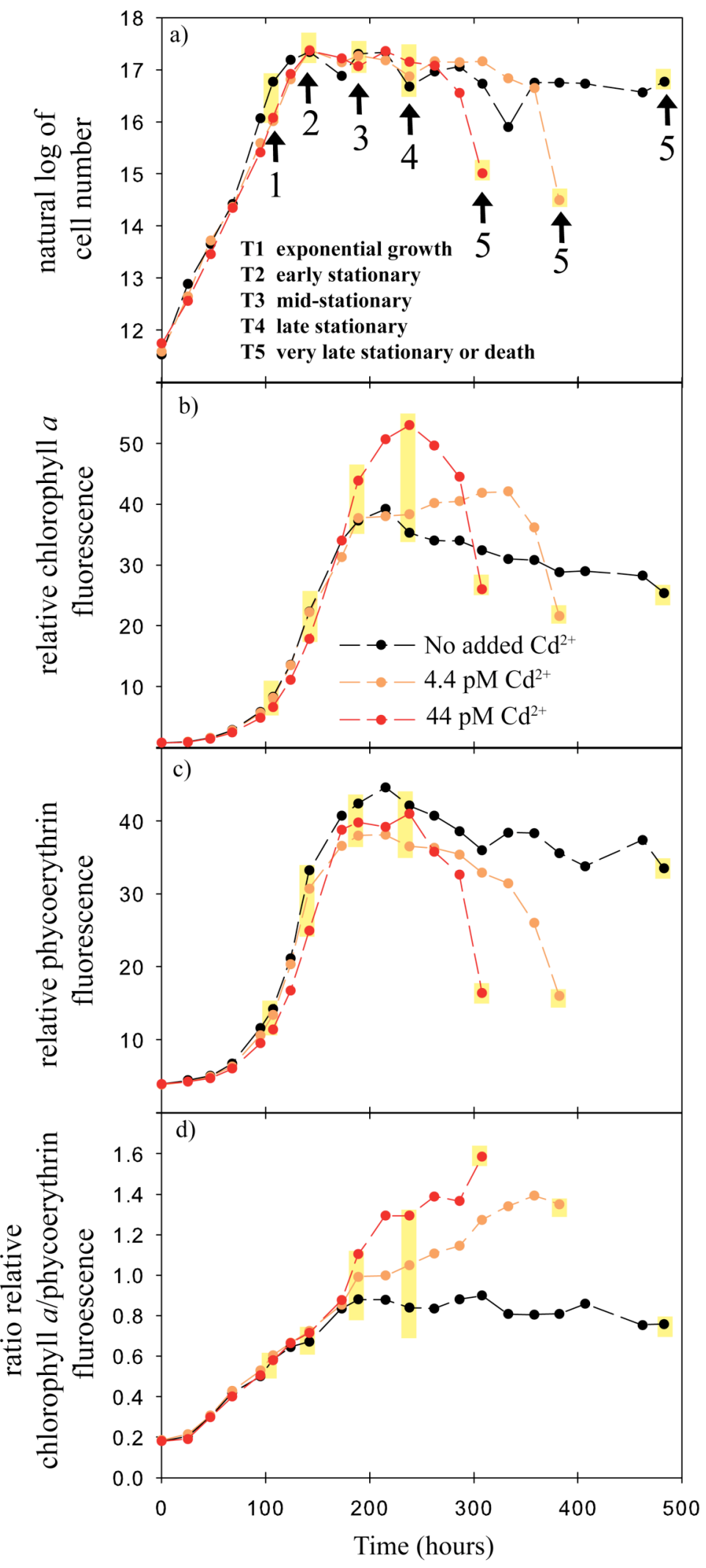

Figure 3.4: Physiological factors with time in a $1 \mathrm{~L}$ chronic $\mathrm{Cd}^{2+}$ experiment with WH5701. a) Natural log of cell number, b) relative chlorophyll $a$ fluorescence, c) relative phycoerythrin fluorescence, and d) ratio of relative chlorophyll $a$ to phycoerythrin fluorescence. Samples were taken for global proteomic analysis at five timepoints throughout the life of the culture, highlighted in yellow. Growth effects observed in Figures 3.1 and 3.2 were reproduced in this experiment. Each treatment was one bottle. Cells entered stationary phase at about $120 \mathrm{~h}$. The ratio of chlorophyll $a$ to phyocerythrin increases throughout stationary phase with the higher cadmium treatments. 
Since $\mathrm{Cd}$ is generally considered a toxic metal, with only one known nutritive use in a marine diatom carbonic anhydrase, one might expect the diminishment of growth rates upon chronic exposure to Cd. In these experiments with Synechococcus WH5701, this was not the case. With the physiological monitors of relative chlorophyll $a$ and phycoerythrin fluorescence and cell number, no difference among the treatments could be detected during exponential growth. Physiological toxicity in the form of cellular death arresting stationary phase in $\mathrm{Cd}$ treatments in this experiment implies cellular uptake of $\mathrm{Cd}$ and makes one wonder about the cellular destination of $\mathrm{Cd}$ upon entry to the cell and mechanism of toxicity. Differences can be observed in the global proteomic data from exponential growth that could begin to answer this question. Various hypotheses exist for mechanisms of $\mathrm{Cd}$ toxicity or detoxification including the replacement of native metals with $\mathrm{Cd}$, induction of metallothioneins, induction of phytochelatins, and/or binding by smaller ligands such as glutathione. Experimental evidence for the replacement of native metals with $\mathrm{Cd}$ is scarce in animal cells (Martelli et al., 2006) and could only be hinted at with the global proteomic data obtained in this study. To show the replacement of native metals, detailed biochemical work would be required beyond the scope of this study. The induction of metallothioneins by $\mathrm{Cd}$ exposure has been observed at many levels of life from cyanobacteria to mammals (Margoshes and Vallee, 1957; Palmiter, 1998; Duncan et al., 2006) and also recently from the marine cyanobacterium WH8102 (Cox and Saito, unpublished data). Lowering peptide tolerances in the analysis of WH5701 yields the presence of this small protein, although not enough to quantify relative abundances. In this case, lack of presence does not imply absence.

Physiologically (cell number, chlorophyll $a$ fluorescence and phycoerythrin fluorescence), there is no observable effect of chronic $\mathrm{Cd}$ stress during exponential growth. Chronic $\mathrm{Cd}$ stress does affect the cells, however, giving the $\mathrm{Cd}$ cultures a much faster mortality rate, $1.8 \mathrm{x}$ and $4 \mathrm{x}$ that of the control for $4.4 \mathrm{pM} \mathrm{Cd}^{2+}$ and $44 \mathrm{pM} \mathrm{Cd}^{2+}$ treatments, respectively. Other researchers have found that $\mathrm{Cd}$ interferes with photosynthesis in an unicellular algae, Chlamydomonas reinhardtii (Gillet et al., 2006). 
Our data show that $\mathrm{Cd}$ is interfering with photosynthesis even though there are no observed physiological effects during growth. There is also the question of bioavailability. The cultures are buffered with EDTA, theoretically providing constant picomolar free concentrations of $\mathrm{Cd}^{2+}$. As the cells grow and produce ligands that bind the metals, they could become more (or less) bioavailable. A recent study has suggested that the uptake of copper by field populations of phytoplankton in the subarctic Northeast Pacific Ocean from organic copper complexes is important (Semeniuk et al., 2009). Uptake rates of copper bound to oxidized glutathione in the $0.2-2 \mu \mathrm{M}$ fraction were similar to those of natural ligands (Semeniuk et al., 2009). It is interesting to note that measurements of dissolved and particulate thiols in a repeat experiment show a large pool of intracellular oxidized glutathione in the $44 \mathrm{pM} \mathrm{Cd}^{2+}$ treatment that is not present in the no added $\mathrm{Cd}$ treatment and also less cysteine in the media of the $44 \mathrm{pM} \mathrm{Cd}^{2+}$ treatment than the no added $\mathrm{Cd}$ treatment. These data are consistent with the concept of organically bound $\mathrm{Cd}$ uptake, but also consistent with the idea of uptake of inorganic $\mathrm{Cd}$ with consequent intracellular binding. We cannot at present distinguish between these two processes. Increasing bioavailability of $\mathrm{Cd}$ throughout the progression of the experiment would not fully explain the lack of physiological effects observed during growth phase. There could be differences in metal sensing among the treatments (Waldron et al., 2009), which would be difficult to specifically detect in these data.

\section{Global Proteomic Data - Cluster analysis}

Analysis resulted in the identification of 747 proteins from 153,721 mass spectra over 45 injections ( 3 treatments at 5 time points injected in triplicate) with a 1.7\% peptide false discovery rate using $95 \%$ peptide minimum confidence level, $99.9 \%$ protein minimum confidence level and a minimum of 2 peptides. This experiment identified $22.3 \%$ of the 3346 possible proteins present in the genome of WH5701. Graphs are constructed from an analysis resulting in the identification of 432 proteins from 141,210 mass spectra with a $0.3 \%$ peptide false discovery rate using $95 \%$ peptide minimum confidence level, $99.9 \%$ protein minimum confidence level and a minimum of 4 peptides. Using these more stringent conditions, $12.9 \%$ of the 3346 possible proteins present in the 
genome of WH5701 were identified.

Considering all treatments across time, 152 proteins were above a threshold count average signal of greater than or equal to 5 spectral counts and a minimum difference of 10 counts. Cluster analysis of these 152 proteins (Eisen et al., 1998) reveals changes in protein abundance that appear related to growth phase, but also $\mathrm{Cd}^{2+}$ effects (Figure 3.5). The proteins cluster into six groups, labeled by the growth phase (exponential-death) in which proteins are present and most abundant (Figure 3.5). The order of the treatments on the $\mathrm{x}$-axis in Figure 3.5 is T1-T5 from left to right with the treatments in each time point ordered from no $\mathrm{Cd}$ to $44 \mathrm{pM} \mathrm{Cd}^{2+}$. Group 1 consists of 21 proteins that are most present in exponential growth and early stationary phase (T1 and T2) and not present by midstationary phase, 11 of which are ribosomal proteins (Figure 3.5). Twenty-three Group 2 proteins are present in exponential growth, early and mid-stationary phases (T1, T2, T3) and not present in late stationary or death phases, many of which are involved in metabolism (Figure 3.5). Forty-two proteins that are present in mid-and late stationary phase $(\mathrm{T} 3, \mathrm{~T} 4)$ but not in very late stationary/death phase are considered Group 3 (Figure 3.5). Many are involved in metabolism and regulation, and a few proteases. A small group of 11 proteins comprises Group 4; they are most abundant in early or midstationary to late stationary (Figure 3.5). Four of them are hypothetical proteins, and another is involved in nitrogen metabolism regulation. Group 5 consists of 25 proteins present in mid-stationary to very late stationary/death phase and 14 of them are hypothetical (Figure 3.5). Others are involved in protein folding, iron transport, cell wall degradation, oxidative stress and two in photosystem II. Group 6 can best be described as less abundant in high $\mathrm{Cd}$ treatment during exponential growth but present during both $\mathrm{Cd}$ treatments during death phase and consists of 29 proteins. Many of these proteins are involved in photosynthesis, carbon fixation, ATP synthesis and the ABC transport of nitrogen and phosphorus.

Allowing the treatments ( $\mathrm{x}$-axis) to cluster in addition to the proteins (y-axis) groups the treatments into five clusters (a-e) from left to right (data not shown): a) T1 control and T1 $4.4 \mathrm{pM} \mathrm{Cd}^{2+}$; b) T2 control, T1 $44 \mathrm{pM} \mathrm{Cd}^{2+}$, T2 $4.4 \mathrm{pM} \mathrm{Cd}^{2+}$, and $\mathrm{T} 244$ 
pM Cd ${ }^{2+}$; c) T3 control, T3 $4.4 \mathrm{pM} \mathrm{Cd}^{2+}$, and T3 $44 \mathrm{pM} \mathrm{Cd}^{2+}$; d) T4 $4.4 \mathrm{pM} \mathrm{Cd}^{2+}, \mathrm{T} 444$ pM Cd ${ }^{2+}$, and T5 control; and e) T4 control, T5 $4.4 \mathrm{pM} \mathrm{Cd}^{2+}$, and T5 $44 \mathrm{pM} \mathrm{Cd}^{2+}$. This clustering suggests that exponential growth phase (T1) relative protein abundances 44 pM $\mathrm{Cd}^{2+}$ are similar to early exponential phase (T2) relative protein abundances in all treatments and that late stationary phase $(\mathrm{T} 4)$ no added $\mathrm{Cd}^{2+}$ relative protein abundances are similar to the death phase (T5) $\mathrm{Cd}^{2+}$ relative protein abundances. The latter observation is correlated with an approximate factor of two drop in cell number in the no added $\mathrm{Cd}^{2+}$ treatment from $\mathrm{T} 3$ to $\mathrm{T} 4$. By comparison, cell numbers in the $\mathrm{Cd}^{2+}$ treatments drop about two orders of magnitude from T4 to T5. Together, these observations suggest that the no added $\mathrm{Cd}^{2+}$ treatment underwent a minor episode of cell death from $\mathrm{T} 3$ to $\mathrm{T} 4$ that was reflected in the proteome. 
Group 1: Exponential growth to early stationary

Group 2: Exponential growth to midstationary

Group 3: Midstationary to late stationary

Group 4: Early/midstationary to late stationary

Group 5: Midstationary to death

Group 6: Lower abundance in high cadmium during growth and present in both cadmium during death

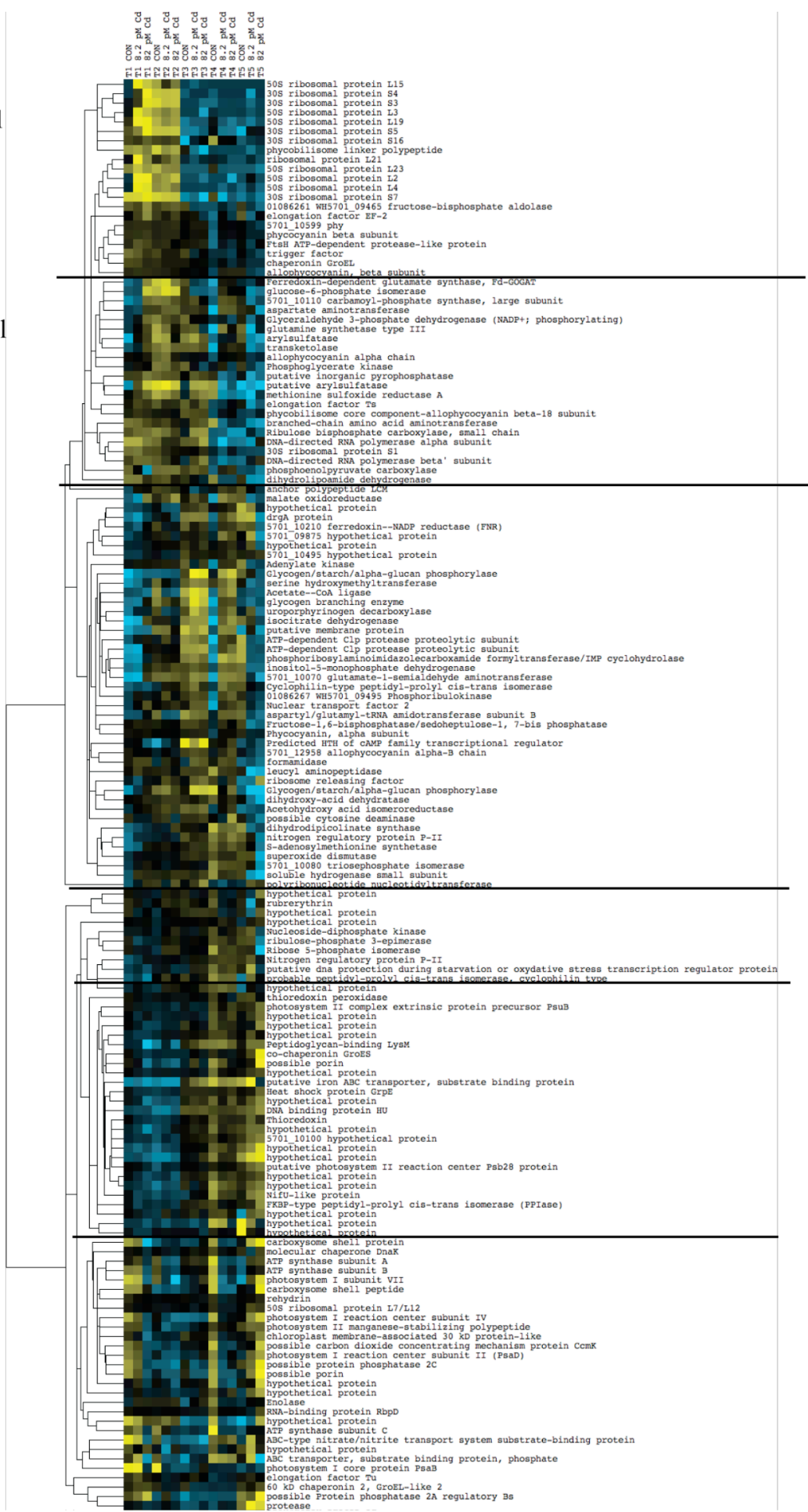

Figure 3.5: Cluster analysis of relative protein abundance. Yellow is higher and blue is lower relative abundance compared to black, the centered mean value. T1 to T5 from left to right. Order at each time point is control, $4.4 \mathrm{pM} \mathrm{Cd}^{2+}$ and $44 \mathrm{pM} \mathrm{Cd}^{2+}$. 152 proteins with at least 5 counts and different by a value of 10 averaged spectral counts from triplicate injections are included here. Data are log transformed, centered and clustered by Kendall's Tau, centroid linkage. 


\section{Global Proteomic Data - Pairwise comparisons by phase of growth}

In addition to cluster analysis, which gave a global view of changes in the entire detected proteome under these specific conditions and revealed very clearly changes in relative protein abundance with growth phase as well as some $\mathrm{Cd}$ effects, pairwise analyses of relative protein abundance in one $\mathrm{Cd}$ treatment compared to the control at each timepoint directly addresses changes caused by the addition of $\mathrm{Cd}$. Figure 3.6 is a summary of this pairwise analysis. It depicts the number of proteins that are more abundant by greater than or equal to two-fold in a $\mathrm{Cd}$ treatment compared to the control (red) and the control compared to Cd (black). Overall, the number of proteins that were more than two-fold differentially abundant was the greatest during late stationary (T4) and very late stationary/death phase (T5) compared to growth through mid-stationary phases (T1-T3) (Figure 3.6). Tables of the actual proteins that changed at each timepoint, as well as their respective KEGG functions will be found under their respective timepoint.

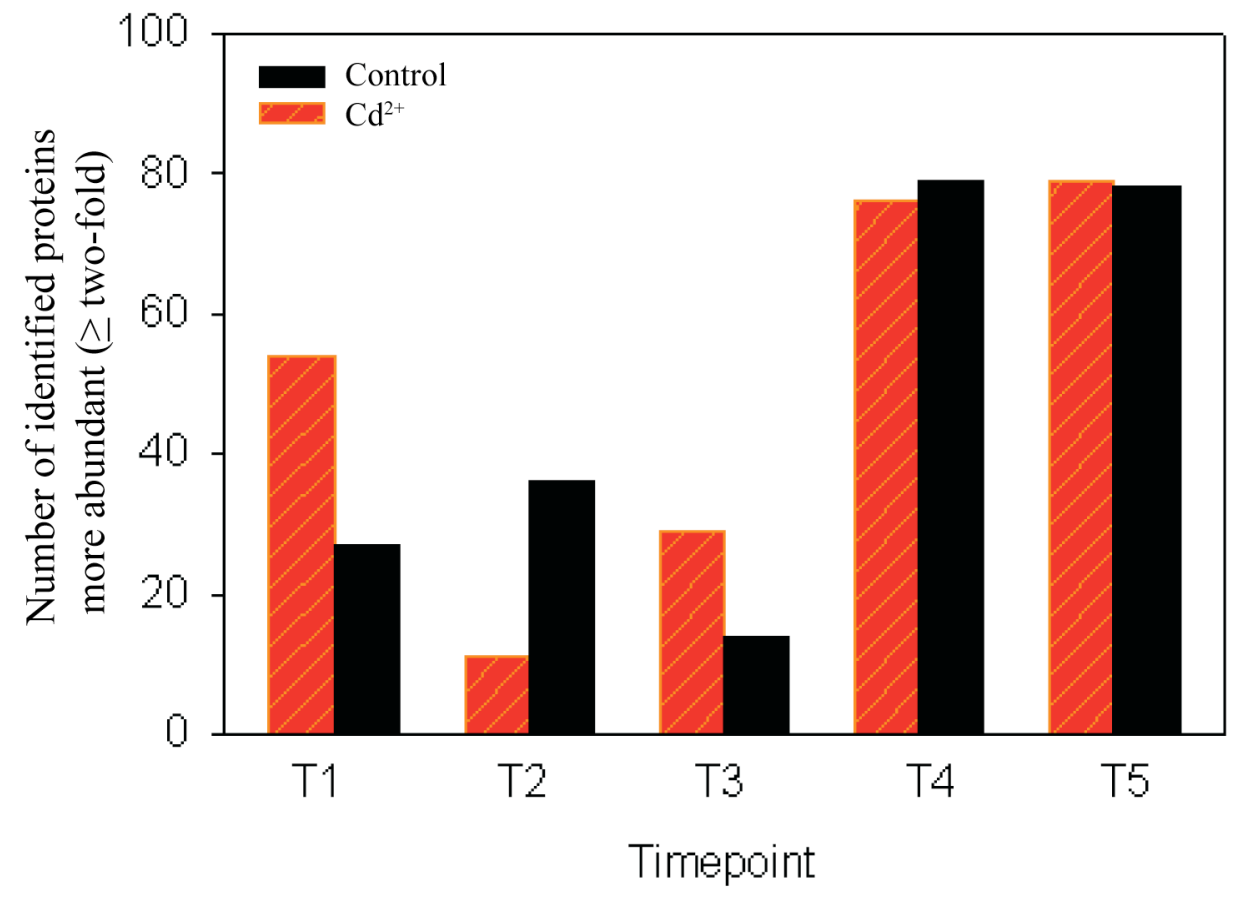

Figure 3.6: Number of identified proteins more abundant ( $\geq$ two-fold) in the control (black) and cadmium treatments (red) by time point. Proteins have an average spectral count of at least 5 . 


\section{Exponential Growth Phase (T1)}

During exponential growth phase, 54 proteins were above a threshold count signal of greater than or equal to 5 spectral counts and were more abundant by $\geq$ two-fold in at least one of the Cd treatments compared to the control (Figure 3.7, Table 3.1). Twentyseven proteins by the same stringencies were more abundant in the control compared to at least one of the $\mathrm{Cd}$ treatments (Table 3.2). 4.4 and $44 \mathrm{pM} \mathrm{Cd}^{2+}$ treatments have an overabundance of many ribosomal proteins, arylsulfatases, an isocitrate dehydrogenase, proteins involved in chlorophyll biosynthesis, and cysteine metabolism, among others compared to the control (Table 3.1). The hypothetical protein WH5701_01855, 16 times more abundant in the high $\mathrm{Cd}$ treatment compared to the control, showed nucleotide BLAST alignment with a query of length 1521 to a putative uroporphyrinogen decarboxylase with a score of 316 bits, $70 \%$ identity of 763 and E-value of $2 \mathrm{e}^{-44}$ (Altschul et al., 1997), another protein involved in chlorophyll biosynthesis. The $\mathrm{Cd}$ treatments have an underabundance of photosystem I, carboxysome and hypothetical proteins relative to the control (Table 3.2). Eight times less abundant in the high $\mathrm{Cd}$ treatment than the control is a WH5701_09565 hypothetical protein that showed nucleotide BLAST alignment with a query of length 594 to an uncharacterized conserved secreted protein in Synechococcus WH7803 with a score of 131 bits, 71\% identity of 304 and E-value of 7e${ }^{27}$ (Altschul et al., 1997). 


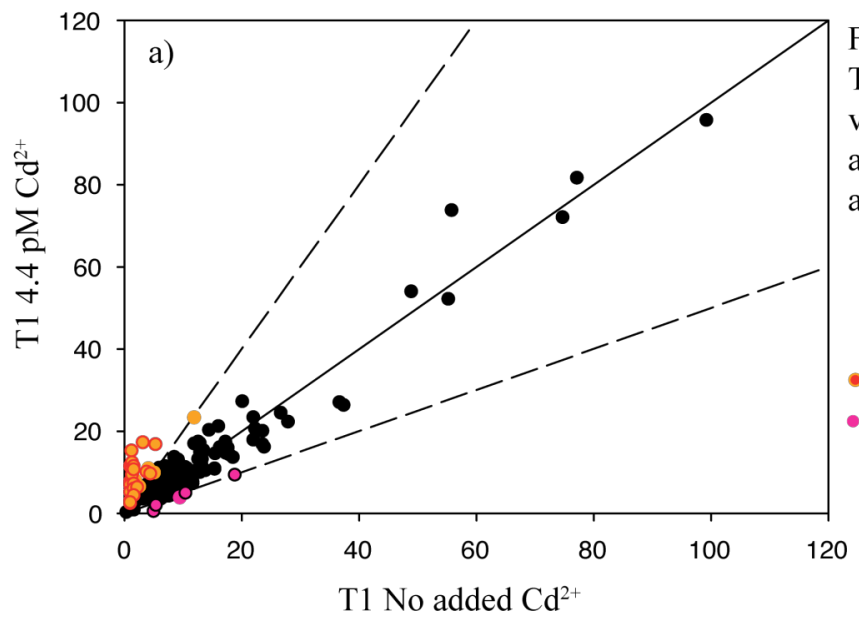

Figure 3.7: Relative abundance of proteins, T1 exponential growth phase. a) $4.4 \mathrm{pM} \mathrm{Cd}^{2+}$ vs. No added $\mathrm{Cd}^{2+}$ b) $44 \mathrm{pM} \mathrm{Cd}^{2+}$ vs. No added $\mathrm{Cd}^{2+}$. Solid line is $1: 1$. Dashed lines are $1: 2$ and $2: 1$.

- less than two-fold abundant

- more abundant in $4.4 \mathrm{pM} \mathrm{Cd}^{2+}$ ( $\geq$ two-fold)

- more abundant in $44 \mathrm{Cd}^{2+}(\geq$ two-fold $)$

- $\circ$ more abundant in both $\mathrm{Cd}^{2+}$ ( $\geq$ two-fold)

- 0 more abundant in no added $\mathrm{Cd}^{2+}$ ( $\geq$ two-fold)

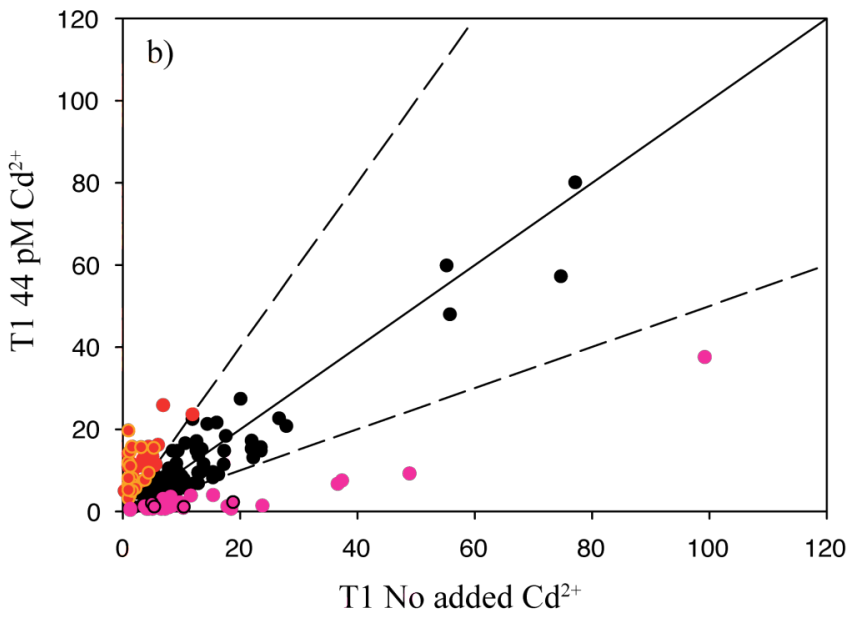


Table 3.1: WH5701 proteins during exponential growth phase (T1) that are more abundant in the $\mathrm{Cd}^{2+}$ treatments than the control by $\geq$ two-fold.

\begin{tabular}{|c|c|c|c|c|}
\hline $\begin{array}{l}\text { WH5701 } \\
\text { ID }\end{array}$ & $\begin{array}{l}\text { KEGG } \\
\text { Function }\end{array}$ & $\begin{aligned} 4.4 \mathrm{r} \\
\mathrm{r}\end{aligned}$ & $\begin{array}{l}1 \mathrm{Cd}^{2+} \text { abundance } \\
\text { tive to control }\end{array}$ & $\begin{array}{l}44 \mathrm{pM} \mathrm{Cd}^{2+} \text { abundance } \\
\text { relative to control }\end{array}$ \\
\hline$\overline{02239}$ & $\overline{\mathrm{St}, \mathrm{L}}$ & putative arylsulfatase & +7.4 & +20.9 \\
\hline 01855 & Ukn & hypothetical protein & +1.1 & +16.4 \\
\hline 01780 & TCA & isocitrate dehydrogenase & +1.4 & +14.0 \\
\hline 12014 & $\mathrm{M}, \mathrm{Nu}, \mathrm{PB}$ & adenylosuccinate synthetase & 0 & +13.2 \\
\hline 07436 & $\mathrm{GI}, \mathrm{T}$ & $30 \mathrm{~S}$ ribosomal protein $\mathrm{S} 4$ & +2.5 & +11.9 \\
\hline 05660 & GI,T & $50 \mathrm{~S}$ ribosomal protein $\mathrm{L} 2$ & +12.3 & +11.7 \\
\hline 13125 & Gly & glucose-6-phosphate isomerase & +1.1 & +11.3 \\
\hline 05540 & GI,T & $30 \mathrm{~S}$ ribosomal protein $\mathrm{S} 9$ & +2.6 & +11.2 \\
\hline 04620 & St,L & arylsulfatase & +6.8 & +10.0 \\
\hline 10070 & Po,Chl & $\begin{array}{c}\text { glutamate-1-semialdehyde } \\
\text { aminotransferase }\end{array}$ & -1.1 & +9.5 \\
\hline 05570 & GI,T & 30S ribosomal protein $\mathrm{S} 13$ & +3.9 & +9.5 \\
\hline 05670 & GI,T & $50 \mathrm{~S}$ ribosomal protein $\mathrm{L} 4$ & +9.9 & +8.8 \\
\hline 09740 & Ukn & hypothetical protein & +3.2 & +8.5 \\
\hline 10110 & $\mathrm{M}, \mathrm{A}, \mathrm{Nu}$ & $\begin{array}{l}\text { carbamoyl-phosphate synthase } \\
\text { large subunit }\end{array}$ & +1.5 & +8.3 \\
\hline 01005 & $\mathrm{M}, \mathrm{N}$ & $\begin{array}{l}\text { ferredoxin-dependent glutamate } \\
\text { synthase, Fd-GOGAT }\end{array}$ & +1.5 & +8.3 \\
\hline 05590 & GI,T & 50S ribosomal protein L15 & +1.4 & +8.3 \\
\hline 05645 & GI,T & $30 \mathrm{~S}$ ribosomal protein $\mathrm{S} 3$ & +1.8 & +7.3 \\
\hline 05605 & GI,T & 50S ribosomal protein L6 & +7.9 & +6.6 \\
\hline 13665 & GI,T & 30 S ribosomal protein $\mathrm{S} 2$ & +2.9 & +6.4 \\
\hline 01045 & GI,T & $30 \mathrm{~S}$ ribosomal protein $\mathrm{S} 10$ & +2.1 & +6.1 \\
\hline 09149 & $\mathrm{C}$ & malate oxidoreductase & -1.9 & +5.9 \\
\hline 05615 & GI,T & $50 \mathrm{~S}$ ribosomal protein L5 & +7.5 & +5.7 \\
\hline 15591 & $\mathrm{M}, \mathrm{V}, \mathrm{Po}, \mathrm{Chl}$ & $\delta$-aminolevulinic acid dehydratase & +1.5 & +5.5 \\
\hline 03654 & $\mathrm{M}$ & $\begin{array}{l}\text { glycogen/starch/alpha-glucan } \\
\text { phosphorylase }\end{array}$ & +2.7 & +5.3 \\
\hline 05640 & GI,T & 50S ribosomal protein L16 & +4.6 & +5.2 \\
\hline 05675 & GI,T & $50 \mathrm{~S}$ ribosomal protein $\mathrm{L} 3$ & +7.3 & +5.1 \\
\hline 13900 & GI,T & 50S ribosomal protein L19 & +5.5 & +5.0 \\
\hline 14966 & GI,T & 50 S ribosomal protein $\mathrm{L} 27$ & +3.9 & +4.2 \\
\hline 05595 & GI,T & $30 \mathrm{~S}$ ribosomal protein $\mathrm{S} 5$ & +1.5 & +4.0 \\
\hline 05975 & $\mathrm{Cy}$, Met,Se & S-adenosylmethionine synthetase & +1.4 & +3.9 \\
\hline 05565 & GI,T & $30 \mathrm{~S}$ ribosomal protein $\mathrm{S} 11$ & +1.8 & +3.9 \\
\hline 01600 & $\mathrm{M}, \mathrm{E}, \mathrm{C}, \mathrm{An}$ & transketolase & +1.7 & +3.8 \\
\hline 02844 & $\mathrm{M}, \mathrm{E}, \mathrm{C}$ & $\begin{array}{l}\text { glyceraldehyde 3-phosphate } \\
\text { dehydrogenase (NADP+; }\end{array}$ & & \\
\hline & & phosphorylating) & +1.5 & +3.7 \\
\hline 08064 & $\mathrm{M}, \mathrm{Nu}, \mathrm{PB}$ & $\begin{array}{l}\text { inositol-5-monophosphate } \\
\text { dehydrogenase }\end{array}$ & -1.2 & +3.6 \\
\hline 06556 & $\mathrm{M}, \mathrm{Nu}, \mathrm{GI}$ & $\begin{array}{l}\text { polyribonucleotide } \\
\text { nucleotidyltransferase }\end{array}$ & +1.8 & +3.4 \\
\hline
\end{tabular}


Table 3.1 (continued):

\begin{tabular}{|c|c|c|c|c|}
\hline $\begin{array}{l}\text { WH5701 } \\
\text { ID }\end{array}$ & $\begin{array}{l}\text { KEGG } \\
\text { Function }\end{array}$ & $\begin{aligned} 4.4 \mathrm{pl} \\
\mathrm{rel}\end{aligned}$ & $\begin{array}{l}\mathrm{Cd}^{2+} \text { abundance } \\
\text { ative to control }\end{array}$ & $\begin{array}{l}44 \mathrm{pM} \mathrm{Cd}^{2+} \text { abundance } \\
\text { relative to control }\end{array}$ \\
\hline$\overline{04010}$ & $\overline{\mathrm{U}, \mathrm{Si}}$ & nuclear transport factor 2 & +1.8 & +3.1 \\
\hline 02259 & GI & possible protein phosphatase & & \\
\hline & & $2 \mathrm{~A}$ regulatory $\mathrm{Bs}$ & +1.5 & +2.9 \\
\hline 02929 & U,M & $\begin{array}{l}\text { soluble hydrogenase small subunit } \\
\text { (DHSS) }\end{array}$ & +3.2 & +2.9 \\
\hline 08944 & $\mathrm{M}, \mathrm{N}, \mathrm{A}, \mathrm{S}$ & glutamine synthetase type III & +1.7 & +2.7 \\
\hline 01030 & GI,T & elongation factor EF-2 & +1.5 & +2.7 \\
\hline 01085 & $\mathrm{M}, \mathrm{C}, \mathrm{A}, \mathrm{Cy}$ & aspartate aminotransferase & -1.1 & +2.6 \\
\hline 05625 & GI,T & 50S ribosomal protein L14 & +2.9 & +2.6 \\
\hline 05655 & GI,T & 30S ribosomal protein S19 & +1.1 & +2.4 \\
\hline 15281 & PS & anchor polypeptide $\mathrm{L}_{\mathrm{CM}}$ & +2.2 & +2.1 \\
\hline 11829 & $(\mathrm{~N})$ & nitrogen regulatory protein P-II & +1.4 & +2.0 \\
\hline 10080 & $\mathrm{C}$ & triose phosphate isomerase & +1.5 & +2.0 \\
\hline 05545 & GI,T & 50S ribosomal protein L13 & +2.7 & +2.0 \\
\hline 14961 & GI,T & $50 \mathrm{~S}$ ribosomal protein $\mathrm{L} 21$ & +8.8 & +3.2 \\
\hline 02989 & GI,T & 50S ribosomal protein L20 & +5.4 & +3.3 \\
\hline 01770 & $\mathrm{M}, \mathrm{V}$ & heme oxygenase & +4.9 & +2.9 \\
\hline 11799 & En, Tr & $\begin{array}{c}\text { polar amino acid transport system } \\
\text { substrate-binding protein }\end{array}$ & +4.3 & +2.1 \\
\hline 02614 & $\mathrm{ABC}, \mathrm{P}$ & $\mathrm{ABC}$ transporter, phosphate & +2.7 & -6.6 \\
\hline 02994 & GI,T & 50S ribosomal protein L35 & +2.6 & +1.8 \\
\hline 07346 & $\mathrm{GI}, \mathrm{Rr}, \mathrm{D}$ & cell division protein (ftsZ) & +2.2 & -1.0 \\
\hline
\end{tabular}

Arranged in highest to lowest fold change, $44 \mathrm{pM} \mathrm{Cd}^{2+}$, then $4.4 \mathrm{pM} \mathrm{Cd}^{2+} .+=$ fold greater than control, $-=$ fold less than control, $\mathrm{St}=$ steriod hormone synthesis, $\mathrm{L}=$ lipid biosynthesis, $\mathrm{Ukn}=$ unknown, $\mathrm{TCA}=\mathrm{TCA}$ cycle, $\mathrm{M}$ $=$ metabolism, $\mathrm{Nu}=$ nucleic acid metabolism, $\mathrm{PB}=$ purine biosynthesis, $\mathrm{GI}=$ genetic information processing, $\mathrm{T}$ $=$ translation, $\mathrm{Gly}=$ glycolosis, $\mathrm{Po}=$ porphryn biosynthesis, $\mathrm{Chl}=$ chlorophyll biosynthesis, Met $=$ methionine synthesis, $\mathrm{Se}=$ selenoaminoacid synthesis, $\mathrm{E}=$ energy metabolism, $\mathrm{An}=$ ansamycin metabolism, $\mathrm{U}=$ unclassified, $\mathrm{Si}=$ signalling, $\mathrm{N}=$ nitrogen, $\mathrm{A}=$ amino acid metabolism, $\mathrm{S}=$ sulfur metabolism, $\mathrm{C}=\mathrm{CO}_{2}$ fixation, $\mathrm{Cy}=$ cysteine metabolism, $\mathrm{PS}=$ photosynthesis, $\mathrm{V}=$ vitamin metabolism, En = environmental sensing, $\mathrm{Tr}=$ transport, $\mathrm{ABC}=\mathrm{ABC}$-type membrane transport, $\mathrm{Rr}=$ replication and repair, $\mathrm{D}=$ cell division 
Table 3.2: WH5701 proteins during exponential growth phase (T1) that are two-fold or more less abundant in the $\mathrm{Cd}^{2+}$ treatments compared to the control.

\begin{tabular}{|c|c|c|c|c|}
\hline $\begin{array}{l}\text { WH5701 } \\
\text { ID }\end{array}$ & $\begin{array}{l}\text { KEGG } \\
\text { Function }\end{array}$ & $\begin{array}{r}4.4 \mathrm{pM} \mathrm{C} \\
\text { relati }\end{array}$ & $\begin{array}{l}d^{2+} \text { abundance } \\
\text { e to control }\end{array}$ & $\begin{array}{l}44 \mathrm{pM} \mathrm{Cd}^{2+} \text { abundance } \\
\text { relative to control }\end{array}$ \\
\hline$\overline{11339}$ & $\mathrm{C}$ & carboxysome shell protein & -1.4 & -28 \\
\hline 01585 & PS & photosystem I subunit VII (psaC) & -1.2 & -14.4 \\
\hline 05480 & PS & photosystem I core protein (psaB) & +1.1 & -11.3 \\
\hline 07859 & M,E,PS & apocytochrome f precursor (petA) & -1.6 & -10.8 \\
\hline 05475 & PS & photosystem I core protein (psaA) & +1.1 & -9.9 \\
\hline 05780 & $\mathrm{M}, \mathrm{E}, \mathrm{C}, \mathrm{Cb}$ & phosphoenolpyruvate carboxylase & +1.1 & -9.9 \\
\hline 06176 & PS & $\begin{array}{l}\text { photosystem I reaction center subunit IV } \\
\text { (psaE) }\end{array}$ & -2.0 & -8.4 \\
\hline 09565 & Ukn & hypothetical protein & -1.3 & -8.2 \\
\hline 15251 & PS & ATP synthase subunit B & -1.4 & -7.8 \\
\hline 00710 & $\mathrm{U}, \mathrm{Om}$ & possible porin (som) & -1.8 & -7.5 \\
\hline 15961 & $\mathrm{U}$ & possible protein phosphatase $2 \mathrm{C}$ & -1.6 & -6.4 \\
\hline 07894 & PS & $\begin{array}{l}\text { photosystem I reaction center } \\
\text { subunit III (psaF) }\end{array}$ & +1.2 & -6.3 \\
\hline 06000 & PS & $\begin{array}{l}\text { photosystem II chlorophyll-binding } \\
\text { protein }\end{array}$ & +1.4 & -5.4 \\
\hline 05795 & PS & $\begin{array}{l}\text { photosystem I reaction center } \\
\text { subunit II (psaD) }\end{array}$ & -1.4 & -5.4 \\
\hline 15121 & PS & ATP synthase subunit B & +1.1 & -5.3 \\
\hline 11319 & $\mathrm{C}$ & $\begin{array}{l}\text { possible carbon dioxide concentrating } \\
\text { mechanism }(\mathrm{CcmK})\end{array}$ & -1.4 & -5.0 \\
\hline 00840 & Ukn & hypothetical protein & -1.2 & -4.8 \\
\hline 13795 & Ukn & hypothetical protein & -2.7 & -4.6 \\
\hline 02604 & Ukn & hypothetical protein & -1.2 & -4.5 \\
\hline 07651 & PS & $\begin{array}{l}\text { chloroplast membrane-associated } \\
30 \mathrm{kD} \text { protein-like }\end{array}$ & -1.6 & -4.5 \\
\hline 01150 & PS & $\begin{array}{l}\text { photosystem II manganese- } \\
\text { stabilizing polypeptide }\end{array}$ & -1.1 & -3.9 \\
\hline 13075 & Ukn & hypothetical protein & -1.5 & -3.0 \\
\hline 11354 & $\mathrm{C}$ & carboxysome shell peptide & -1.1 & -2.6 \\
\hline 15156 & Ukn & hypothetical protein & -8.8 & -2.5 \\
\hline 11984 & PS & possible ferredoxin $(2 \mathrm{Fe}-2 \mathrm{~S})$ & -1.1 & -2.3 \\
\hline 13850 & Ukn & hypothetical protein & -1.7 & -2.3 \\
\hline 13745 & M,E,C & ribulose-phosphate 3-epimerase & -2.5 & -1.8 \\
\hline
\end{tabular}

Arranged in highest to lowest fold change, $44 \mathrm{pM} \mathrm{Cd}^{2+}$, then $4.4 \mathrm{pM} \mathrm{Cd}^{2+} .+=$ fold greater than control, $-=$ fold less than control, * = also in Table 3.1, $\mathrm{C}=\mathrm{CO}_{2}$ fixation; $\mathrm{PS}=$ photosynthesis, $\mathrm{M}=$ metabolism, $\mathrm{E}=$ energy metabolism, $\mathrm{Cb}=$ carbohydrate metabolism, $\mathrm{Ukn}=$ unknown, $\mathrm{U}=$ unclassified, $\mathrm{Om}=$ outer membrane protein 


\section{Early Stationary Phase (T2)}

During early stationary phase, 11 proteins were above a threshold count signal of greater than or equal to 5 spectral counts and were more abundant by $\geq$ two-fold in at least one of the Cd treatments compared to the control (Table II.1). Thirty-six proteins by the same stringencies were more abundant in the control compared to at least one of the Cd treatments (Table II.2). 4.4 and $44 \mathrm{pM} \mathrm{Cd}^{2+}$ treatments have an overabundance of 4 hypothetical proteins, and an extra cellular solute-binding protein family 3 , among others, compared to the control (Table II.1). The $\mathrm{Cd}$ treatments have an underabundance of photosystem I, ATP synthase, arylsulfatase and six ribosomal proteins relative to the control (Table II.2).

\section{Mid-Stationary Phase (T3)}

During mid-stationary phase, 24 proteins were above a threshold count signal of greater than or equal to 5 spectral counts and were more abundant by $\geq$ two-fold in at least one of the Cd treatments compared to the control (Table II.3). Fourteen proteins by the same stringencies were more abundant in the control compared to at least one of the Cd treatments (Table II.4). 4.4 and $44 \mathrm{pM} \mathrm{Cd}^{2+}$ treatments have an overabundance of two proteins involved in chlorophyll biosynthesis, coproporphyrinogen III oxidase and uroporphyrinogen decarboxylase, a stationary phase survival protein (SurE), the extracellular solute-binding protein family 3, and the putative arylsulfatase among others, compared to the control (Table II.3). The Cd treatments have an underabundance of a few purine biosynthesis proteins and two phycobilisome proteins, among others relative to the control (Table II.4).

\section{Late Stationary Phase (T4)}

During late stationary phase, 76 proteins were above a threshold count signal of greater than or equal to 5 spectral counts and were more abundant by $\geq$ two-fold in at least one of the $\mathrm{Cd}$ treatments compared to the control (Table II.5). Seventy-nine proteins by the same stringencies were more abundant in the control compared to at least one of the Cd treatments (Table II.6). 4.4 and $44 \mathrm{pM} \mathrm{Cd}^{2+}$ treatments have an overabundance of three proteins involved in chlorophyll biosynthesis, two proteins 
involved in cysteine and sulfur metabolism, 16 hypothetical proteins, and phycobilisomeassociated pigments, among others, compared to the control (Table II.5). The Cd treatments have an underabundance of ATP synthase, three carboxysome-related proteins, and 25 hypothetical proteins, among others relative to the control (Table II.6).

\section{Very Late Stationary or Death Phase (T5)}

During very late stationary phase for the control and death phase for the $\mathrm{Cd}$ treatments, 79 proteins were above a threshold count signal of greater than or equal to five spectral counts and were more abundant by $\geq$ two-fold in at least one of the $\mathrm{Cd}$ treatments compared to the control (Table 3.3). Seventy-eight proteins by the same stringencies were more abundant in the control compared to the $\mathrm{Cd}$ treatments (Table 3.4). 4.4 and $44 \mathrm{pM} \mathrm{Cd}^{2+}$ treatments have an overabundance of 36 hypothetical proteins, photosystem I proteins, carboxysome proteins, and ATP synthase, among others, compared to the control (Table 3.3). The $\mathrm{Cd}$ treatments have an underabundance of 12 hypothetical proteins, phycobilisome-related pigments, a protein involved in chlorophyll biosynthesis, among others relative to the control (Table 3.4). 
Table 3.3: WH5701 proteins during very late stationary or death phase (T5) that are more abundant in the $\mathrm{Cd}^{2+}$ treatments than the control by $\geq$ two-fold.

\begin{tabular}{|c|c|c|c|c|}
\hline $\begin{array}{l}\text { WH570 } \\
\text { ID }\end{array}$ & $\begin{array}{l}\text { KEGG } \\
\text { Function }\end{array}$ & $\begin{array}{r}4.4 \mathrm{pl} \\
\text { rel }\end{array}$ & $\begin{array}{l}\mathrm{M} \mathrm{Cd^{2+ }} \text { abundance } \\
\text { lative to control }\end{array}$ & $\begin{array}{l}44 \mathrm{pM} \mathrm{Cd}^{2+} \text { abundance } \\
\text { relative to control }\end{array}$ \\
\hline 01585 & PS & photosystem I subunit VII & +8.1 & +27.2 \\
\hline 13075 & Ukn & hypothetical protein & +2.6 & +24.9 \\
\hline 13725 & Ukn & hypothetical protein & +6.0 & +14.5 \\
\hline 00710 & $\mathrm{Mp}$ & possible porin & +3.4 & +14.5 \\
\hline 04880 & Ukn & hypothetical protein & +8.9 & +11.4 \\
\hline 11924 & $\mathrm{U}, \mathrm{T}$ & ribosome releasing factor & +1.1 & +10.8 \\
\hline 15671 & $\mathrm{U}$ & methionine sulfoxide reductase B & +3.0 & +8.8 \\
\hline 02979 & Ukn & hypothetical protein & +1.0 & +8.4 \\
\hline 11339 & $\mathrm{C}$ & carboxysome shell protein & +4.8 & +8.1 \\
\hline 00705 & $\mathrm{Mp}$ & possible porin & +1.2 & +7.7 \\
\hline 14306 & Ukn & hypothetical protein & +2.5 & +7.1 \\
\hline 14296 & Ukn & hypothetical protein & +3.5 & +6.6 \\
\hline 15116 & $\mathrm{GI}, \mathrm{F}$ & co-chaperonin GroES & +1.6 & +6.5 \\
\hline 11354 & $\mathrm{C}$ & carboxysome shell peptide & -1.3 & +6.4 \\
\hline 07276 & Ukn & hypothetical protein & +2.3 & +6.3 \\
\hline 14301 & Ukn & hypothetical protein & +2.5 & +5.9 \\
\hline 05795 & PS & $\begin{array}{l}\text { photosystem I reaction center } \\
\text { subunit II (psaD) }\end{array}$ & +3.1 & +5.6 \\
\hline 11319 & $\mathrm{C}$ & $\begin{array}{l}\text { possible carbon dioxide concentrating } \\
\text { mechanism protein }(\mathrm{Ccmk})\end{array}$ & $\mathrm{g}+1.2$ & +5.5 \\
\hline 06176 & PS & $\begin{array}{l}\text { photosystem I reaction center } \\
\text { subunit IV }\end{array}$ & +2.9 & +5.3 \\
\hline 02634 & GI,T & $30 \mathrm{~S}$ ribosomal protein $\mathrm{S} 6$ & +1.3 & +5.2 \\
\hline 05845 & Ukn & hypothetical protein & +1.5 & +5.1 \\
\hline 15071 & U, GI & $\begin{array}{l}\text { DNA-directed RNA polymerase } \\
\text { omega subunit }\end{array}$ & +1.3 & +5.0 \\
\hline 10230 & $\mathrm{U}, \mathrm{M}, \mathrm{Nu}$ & $\begin{array}{l}\text { possible cAMP phosphodiesterase } \\
\text { class-II }\end{array}$ & +3.3 & +5.0 \\
\hline 15241 & PS & ATP synthase subunit A & +4.1 & +4.8 \\
\hline 12273 & Ukn & hypothetical protein & +4.3 & +4.6 \\
\hline 15886 & Ukn & hypothetical protein & -1.1 & +4.5 \\
\hline 01175 & Ukn & hypothetical protein & +1.4 & +4.4 \\
\hline 15441 & $\mathrm{U}, \mathrm{GI}$ & $\begin{array}{l}\text { DNA-directed RNA polymerase } \\
\text { beta' subunit }\end{array}$ & +2.3 & +4.1 \\
\hline 15961 & GI & possible protein phosphatase $2 \mathrm{C}$ & +1.4 & +4.1 \\
\hline 05950 & Ukn & hypothetical protein & +4.1 & +4.1 \\
\hline 05560 & $\mathrm{U}, \mathrm{GI}$ & $\begin{array}{l}\text { DNA-directed RNA polymerase } \\
\text { alpha subunit }\end{array}$ & -1.4 & +4.0 \\
\hline \multirow[t]{2}{*}{16056} & M,GI,F,En & & & \\
\hline & $\mathrm{Pd}$ & possible serine protease & +3.3 & +3.8 \\
\hline 12638 & Ukn & hypothetical protein & +1.4 & +3.8 \\
\hline 15121 & PS & ATP synthase subunit B & +2.6 & +3.2 \\
\hline 05925 & Ukn & hypothetical protein & -1.1 & +3.1 \\
\hline 07396 & Ukn & hypothetical protein & +1.5 & +3.0 \\
\hline \multirow[t]{2}{*}{02259} & GI & possible protein phosphatase & & \\
\hline & & $2 \mathrm{~A}$ regulatory $\mathrm{Bs}$ & -1.3 & +2.9 \\
\hline
\end{tabular}


Table 3.3 (continued, page 2 of 3 )

\begin{tabular}{|c|c|c|c|c|}
\hline $\begin{array}{l}\text { WH570 } \\
\text { ID } \\
\end{array}$ & $\begin{array}{l}1 \text { KEGG } \\
\text { Function }\end{array}$ & Protein & $\begin{array}{l}4 \mathrm{pM} \mathrm{Cd}^{2+} \text { abundance } \\
\text { relative to control }\end{array}$ & $\begin{array}{c}44 \mathrm{pM} \mathrm{Cd}^{2+} \text { abundance } \\
\text { relative to control }\end{array}$ \\
\hline 09099 & Ukn & hypothetical protein & +3.2 & +2.9 \\
\hline 07651 & PS & chloroplast membrane-associated & & \\
\hline & & $30 \mathrm{kD}$ protein-like & +1.5 & +2.9 \\
\hline 11349 & $\mathrm{U}$ & methionine sulfoxide reductase $\mathrm{A}$ & -2.2 & +2.7 \\
\hline 16031 & Ukn & hypothetical protein & +2.4 & +2.7 \\
\hline 06581 & $\mathrm{U}, \mathrm{N}$ & NifU-like protein & +2.1 & +2.7 \\
\hline 10549 & Ukn & hypothetical protein & -2.1 & +2.7 \\
\hline 05815 & Chl & coproporphyrinogen III oxidase & +1.4 & +2.7 \\
\hline 02030 & GI,T & 50S ribosomal protein L9 & & \\
\hline 08194 & Ukn & hypothetical protein & +1.2 & +2.5 \\
\hline 02664 & Ukn & hypothetical protein & -1.6 & +2.5 \\
\hline 14786 & GI,F & $\begin{array}{l}\text { FKBP-type peptidyl-prolyl cis- } \\
\text { trans isomerase (PPIase) }\end{array}$ & +1.1 & +2.4 \\
\hline 12034 & Ukn & hypothetical protein & +1.5 & +2.4 \\
\hline 06691 & $\mathrm{Pp}, \mathrm{Pd}$ & protease & +4.0 & +2.4 \\
\hline 02829 & Ukn & hypothetical protein & +1.6 & +2.4 \\
\hline 06556 & $\mathrm{M}, \mathrm{Nu}, \mathrm{GI}$ & $\begin{array}{l}\text { polyribonucleotide nucleotidyl- } \\
\text { transferase }\end{array}$ & +3.0 & +2.4 \\
\hline 00770 & $\mathrm{GI}, \mathrm{Rr}, \mathrm{Ra}$ & DNA repair protein $(\operatorname{radA})$ & +1.2 & +2.4 \\
\hline 08389 & Ukn & hypothetical protein & +2.0 & +2.4 \\
\hline 14806 & Ukn & hypothetical protein & -2.0 & +2.2 \\
\hline 05140 & M,Cb,Gly & & & \\
\hline & $\mathrm{E}, \mathrm{C}$ & phosphoglycerate kinase & -1.0 & +2.2 \\
\hline 13085 & Ukn & hypothetical protein & +1.8 & +2.1 \\
\hline 02654 & Ukn & hypothetical protein & +2.4 & +2.1 \\
\hline 06191 & $\mathrm{Cw}$ & peptidoglycan binding (LysM) & +2.0 & +2.0 \\
\hline 11644 & Ukn & hypothetical protein & +8.6 & +5.9 \\
\hline 14406 & $\mathrm{GI}, \mathrm{F}, \mathrm{En}, \mathrm{Ca}$ & $\begin{array}{l}\text { probable peptidyl-prolyl cis-trans } \\
\text { isomerase, cyclophilin type }\end{array}$ & +7.7 & +3.3 \\
\hline 04715 & $\mathrm{~N}, \mathrm{ABC}$ & $\begin{array}{l}\text { ABC-type nitrate/nitrite } \\
\text { transport system }\end{array}$ & +7.4 & +2.0 \\
\hline 11799 & $\mathrm{En}, \mathrm{Tr}$ & $\begin{array}{l}\text { polar amino acid transport system } \\
\text { substrate binding protein }\end{array}$ & +6.6 & +2.4 \\
\hline 02409 & Ukn & hypothetical protein & +6.2 & +2.1 \\
\hline 15736 & Ukn & hypothetical protein & +5.9 & +2.1 \\
\hline 15626 & $\mathrm{U}$ & putative membrane protein & +5.7 & +1.1 \\
\hline 04975 & Ukn & hypothetical protein & +5.6 & -1.5 \\
\hline 11524 & $\mathrm{Cy}, \mathrm{Se}$ & cysteine synthase A & +4.8 & -3.3 \\
\hline 02614 & $\mathrm{P}, \mathrm{ABC}$ & $\begin{array}{l}\mathrm{ABC} \text { transporter, substrate binding } \\
\text { protein, phosphate }\end{array}$ & +4.1 & -8.5 \\
\hline 11729 & Ukn & hypothetical protein & +3.7 & -1.5 \\
\hline 09875 & Ukn & hypothetical protein & +3.5 & -4.7 \\
\hline 02904 & Ukn & hypothetical protein & +3.3 & +2.5 \\
\hline 03890 & $\mathrm{U}, \mathrm{O}$ & $\begin{array}{l}\text { putative DNA protection during } \\
\text { starvation or oxidative stress } \\
\text { transcription regulator protein }\end{array}$ & +3.0 & $-2.2 *$ \\
\hline
\end{tabular}


Table 3.3 (continued, page 3 of 3 )

\begin{tabular}{|c|c|c|c|c|}
\hline $\begin{array}{l}\text { WH570 } \\
\text { ID }\end{array}$ & $\begin{array}{l}1 \text { KEGG } \\
\text { Function }\end{array}$ & Protein & $\begin{array}{l}4.4 \mathrm{pM} \mathrm{Cd}^{2+} \text { abundance } \\
\text { relative to control }\end{array}$ & $\begin{array}{l}44 \mathrm{pM} \mathrm{Cd}^{2+} \text { abundance } \\
\text { relative to control }\end{array}$ \\
\hline 15926 & $\mathrm{M}, \mathrm{Cb}, \mathrm{Nu}$ & phosphoglucomutase (pgm) & +2.6 & -2.7 \\
\hline 02264 & Ukn & hypothetical protein & +2.4 & -1.3 \\
\hline 12533 & Chl & uroporphyrinogen decarboxylase & +2.4 & -2.5 \\
\hline 08984 & M,V,B6 & $\begin{array}{l}\text { pyridoxal phosphate biosynthetic } \\
\text { protein }\end{array}$ & +2.2 & -4.4 \\
\hline 12134 & $\begin{array}{l}\mathrm{U}, \mathrm{Fe}, \mathrm{ABC} \\
\mathrm{En}\end{array}$ & $\begin{array}{l}\text { putative iron } \mathrm{ABC} \text { transporter, } \\
\text { substrate binding protein }\end{array}$ & +2.1 & -4.4 \\
\hline 12543 & Ukn & hypothetical protein & +2.1 & $-2.2 *$ \\
\hline
\end{tabular}

Arranged in highest to lowest fold change, $44 \mathrm{pM} \mathrm{Cd}^{2+}$, then $4.4 \mathrm{pM} \mathrm{Cd}^{2+} .+=$ fold greater than control, $-=$ fold less than control, * = also in Table 3.4, PS = photosynthesis, $\mathrm{Ukn}=$ unknown, $\mathrm{Mp}=$ membrane protein, $\mathrm{U}=$ unclassified, $\mathrm{T}=$ translation, $\mathrm{C}=\mathrm{CO}_{2}$ fixation, $\mathrm{GI}=$ genetic information processing, $\mathrm{F}=$ protein folding, $\mathrm{M}=$ metabolism, $\mathrm{Nu}=$ nucleic acid metabolism, En = environmental sensing, $\mathrm{Pd}=$ progein degradation, $\mathrm{N}=$ nitrogen metabolism, $\mathrm{Chl}=$ chlorophyll biosynthesis, $\mathrm{Pp}=$ peptidase, $\mathrm{Rr}=$ replication and repair, $\mathrm{Ra}=$ radiation sensitivity $($ cyanobase) $\mathrm{Cb}=$ carbohydrate metabolism, Gly = glycolosis, $\mathrm{E}=$ energy metabolism, $\mathrm{CW}=$ cell wall membrane biosynthesis (cyanobase), $\mathrm{Ca}=$ calcium signaling pathway, $\mathrm{ABC}=\mathrm{ABC}$-type membrane transport, $\mathrm{Tr}=$ transport, $\mathrm{Cy}=$ cysteine metabolism, $\mathrm{Se}=$ selenoaminoacid synthesis, $\mathrm{P}=$ phosphate metabolism, $\mathrm{O}=$ oxidative stress, $\mathrm{V}=$ vitamin metabolism, B6 = vitamin B6 metabolism, $\mathrm{Fe}=$ iron metabolism. 
Table 3.4: WH5701 proteins during very late stationary or death phase (T5) that are two-fold or more less abundant in the $\mathrm{Cd}^{2+}$ than the control treatments.

\begin{tabular}{|c|c|c|c|c|}
\hline $\begin{array}{l}\text { WH570 } \\
\text { ID }\end{array}$ & $\begin{array}{l}1 \text { KEGG } \\
\text { Function }\end{array}$ & $\begin{array}{l}4.4 \mathrm{pM} \mathrm{Cd} \\
\text { relative }\end{array}$ & $\begin{array}{l}\mathrm{d}^{2+} \text { abundance } \\
\text { e to control }\end{array}$ & $\begin{array}{l}44 \mathrm{pM} \mathrm{Cd}^{2+} \text { abundance } \\
\text { relative to control }\end{array}$ \\
\hline 08594 & $\mathrm{Ukn}$ & hypothetical protein & -7.5 & -32 \\
\hline 01860 & Ukn & hypothetical protein & -7.6 & -22.7 \\
\hline 07171 & $\mathrm{U}, \mathrm{N}$ & $\operatorname{drg} A$ protein & +1.0 & -17.2 \\
\hline 05830 & U,GI & putative ribonuclease $\mathrm{D}$ & -1.4 & -15.1 \\
\hline 10240 & M & probable aminopeptidase $\mathrm{N}$ & -7.6 & -14 \\
\hline 10070 & Po, Chl & $\begin{array}{l}\text { glutamate-1-semialdehyde } \\
\text { aminotransferase }\end{array}$ & -3.6 & -13.3 \\
\hline 02929 & $\mathrm{U}, \mathrm{M}$ & $\begin{array}{l}\text { soluble hydrogenase small } \\
\text { subunit (DHSS) }\end{array}$ & -7.7 & -13.2 \\
\hline 14571 & $\mathrm{C}$ & ribose 5-phosphate isomerase & -1.0 & -13.1 \\
\hline 11489 & $\mathrm{M}, \mathrm{G}$ & probable glutathione reductase & -5.0 & -13 \\
\hline 11104 & Ukn & hypothetical protein & -8.7 & -12 \\
\hline 14791 & $\mathrm{U}, \mathrm{O}$ & superoxide dismutase & -1.0 & -11 \\
\hline 07321 & M,pp & $\begin{array}{l}\text { ATP-dependent Clp protease } \\
\text { proteolytic subunit }\end{array}$ & -8.3 & -10.4 \\
\hline 04620 & St,L & arylsulfatase & -7.4 & -10.2 \\
\hline 01595 & M,L & $\begin{array}{l}\text { 3-oxacyl-(acyl-carrier protein) } \\
\text { synthase II }\end{array}$ & -14.2 & -9.5 \\
\hline 01520 & $\mathrm{M}, \mathrm{Nu}, \mathrm{V}$ & $\begin{array}{l}\text { phosphoribosylaminoimidazole } \\
\text { carboxamide formyltransferase/ } \\
\text { IMP cyclohydrolase }\end{array}$ & -8.7 & -9.1 \\
\hline 03684 & M,A & putative agmatine ureohydrolase & -11 & -8.6 \\
\hline 07326 & M,pp & $\begin{array}{l}\text { ATP-dependent Clp protease } \\
\text { proteolytic subunit }\end{array}$ & -8.2 & -7.7 \\
\hline 14881 & $\mathrm{M}, \mathrm{G}$ & leucyl aminopeptidase & -15.7 & -7.6 \\
\hline 15331 & $(\mathrm{~N})$ & nitrogen regulatory protein P-II & -1.7 & -7.2 \\
\hline 13785 & $\mathrm{M}, \mathrm{A}, \mathrm{V}$ & dihydroxy-acid dehydratase (ilvD) & -3.2 & -7.2 \\
\hline 03624 & $\mathrm{M}$ & GDP-mannose pyrophosphorylase & -2.9 & -7.0 \\
\hline 10080 & $\mathrm{M}, \mathrm{C}$ & triosephosphate isomerase & -1.8 & -7.0 \\
\hline 04930 & GI,T & $\begin{array}{l}\text { aspartyl/glutamyl-tRNA amido- } \\
\text { transferase subunit B }\end{array}$ & -4.3 & -6.9 \\
\hline 07426 & $\begin{array}{l}\text { M,Cb,Gly } \\
\text { TCA,A }\end{array}$ & dihydrolipoamide dehydrogenase & -6.3 & -6.7 \\
\hline 01085 & $\mathrm{M}, \mathrm{C}, \mathrm{A}$ & aspartate aminotransferase & -1.1 & -6.7 \\
\hline 04640 & $\mathrm{M}, \mathrm{Cb}$ & $\begin{array}{l}\text { phosphoglucomutase/phospho- } \\
\text { mannomutase family protein }\end{array}$ & -5.4 & -6.5 \\
\hline 01940 & Ukn & hypothetical protein & -1.6 & -6.2 \\
\hline 12134 & En,ABC & $\begin{array}{l}\text { putative iron } \mathrm{ABC} \text { transporter } \\
\text { substrate binding protein }\end{array}$ & +2.1 & -6.0 \\
\hline 08064 & PB & $\begin{array}{l}\text { inositol-5-monophosphate } \\
\text { dehydrogenase }\end{array}$ & -6.3 & -6.0 \\
\hline 13745 & $\mathrm{M}, \mathrm{E}, \mathrm{C}$ & ribulose-phosphate 3-epimerase & +1.1 & -5.9 \\
\hline 08459 & $\mathrm{GI}, \mathrm{T}$ & $\begin{array}{l}\text { glutamyl-tRNA (Gln) amido- } \\
\text { transferase subunit A }\end{array}$ & $-(0,8.7)$ & -5.9 \\
\hline 02854 & GI,D & $\begin{array}{l}\text { putative cyclophilin-type peptidyl- } \\
\text { prolyl cis-trans isomerase }\end{array}$ & -18.4 & -5.8 \\
\hline
\end{tabular}


Table 3.4 (continued, pg 2 of 3):

\begin{tabular}{|c|c|c|c|c|}
\hline $\begin{array}{l}\text { WH570 } \\
\text { ID }\end{array}$ & $\begin{array}{l}1 \text { KEGG } \\
\text { Function }\end{array}$ & $\begin{array}{l}4.4 \mathrm{pM} \mathrm{Cd} \\
\text { relative }\end{array}$ & $\begin{array}{l}\mathrm{d}^{2+} \text { abundance } \\
\text { e to control }\end{array}$ & $\begin{array}{l}44 \mathrm{pM} \mathrm{Cd}^{2+} \text { abundance } \\
\text { relative to control }\end{array}$ \\
\hline 03039 & M,A,Ly & dihydrodipicolinate synthase & -8.5 & -5.5 \\
\hline 13760 & $\mathrm{M}, \mathrm{Cb}$ & $\begin{array}{l}\text { glucose-1-phosphate adenyl- } \\
\text { transferase (glgC) }\end{array}$ & -11.5 & -5.5 \\
\hline 10210 & PS & ferredoxin--NADP reductase (FNR) & -1.1 & -5.4 \\
\hline 10355 & M,A,Ly & $\begin{array}{l}\text { diaminopimelate decarboxylase } \\
\text { (lysA) }\end{array}$ & -2.5 & -5.4 \\
\hline 15771 & GI,T & $\begin{array}{l}\text { translation initiation factor IF-2B } \\
\text { subunit alpha (elF2B) }\end{array}$ & -1.2 & -5.4 \\
\hline 05975 & Cy,Met,Se & S-adenosylmethionine synthetase & -1.5 & -5.1 \\
\hline 05860 & Ukn & hypothetical protein & -4.1 & -5.1 \\
\hline 05580 & $\mathrm{M}, \mathrm{Nu}, \mathrm{PB}$ & adenylate kinase & -6.4 & -5.0 \\
\hline 03604 & $\mathrm{M}$ & $\begin{array}{l}\text { glycogen/starch/alpha-glucan } \\
\text { phosphorylase }\end{array}$ & -1.7 & -4.8 \\
\hline 10200 & $\mathrm{M}, \mathrm{Cb}, \mathrm{A}, \mathrm{G}$ & $\begin{array}{l}\text { putative glucose 6-phosphate } \\
\text { dehydrogenase }\end{array}$ & -3.7 & -4.8 \\
\hline 09875 & Ukn & hypothetical protein & +3.5 & -4.7 \\
\hline 05145 & $\mathrm{M}, \mathrm{Cb}, \mathrm{E}, \mathrm{C}$ & phosphoglycerate kinase & -2.3 & -4.4 \\
\hline 01780 & TCA & isocitrate dehydrogenase & -1.5 & -4.3 \\
\hline 05930 & PS & phycobilisome linker polypeptide & -1.9 & -4.2 \\
\hline 04010 & U,S & nuclear transport factor 2 & -2.5 & -4.2 \\
\hline 09149 & $\mathrm{C}$ & malate oxidoreductase & -6.5 & -4.0 \\
\hline 13750 & $\begin{array}{l}\text { M,Cb,Gly } \\
\text { pp,E,C }\end{array}$ & $\begin{array}{l}\text { fructose-1,6-bisphosphatase/sedo- } \\
\text { heptulose-1,7-bisphosphatase } \\
\text { (glpx-SEBP) }\end{array}$ & -5.8 & -4.0 \\
\hline 01600 & M,E,C,An & transketolase & -5.4 & -3.5 \\
\hline 04910 & $\mathrm{M}, \mathrm{Nu}$ & nucleoside-diphosphate kinase (ndk) & +1.2 & -3.1 \\
\hline 15281 & PS & anchor polypeptide $\mathrm{L}_{\mathrm{CM}}$ & -1.9 & -2.9 \\
\hline 15291 & PS & allophycocyanin, beta subunit & -2.2 & -2.9 \\
\hline 08944 & $\mathrm{M}, \mathrm{N}, \mathrm{A}, \mathrm{S}$ & glutamine synthetase type III & -14.8 & -2.8 \\
\hline 01470 & $\mathrm{M}, \mathrm{A}, \mathrm{V}$ & serine hydroxymethyltransferase & -3.7 & -2.7 \\
\hline 13670 & GI,T & elongation factor Ts (tsf) & -5.8 & -2.7 \\
\hline 00775 & En & two-component resonse regulator & -5.7 & -2.7 \\
\hline 05150 & $\mathrm{U}, \mathrm{Si}$ & universal stress protein (Usp) & -4.4 & -2.6 \\
\hline 15881 & PS & $\begin{array}{l}\text { phycobilisome rod-core linker } \\
\text { polypeptide cpcG (L-RC 28.5) }\end{array}$ & -1.3 & -2.5 \\
\hline 12094 & $\mathrm{M}, \mathrm{E}, \mathrm{Op}$ & putative inorganic pyrophosphatase & -4.9 & -2.5 \\
\hline 13170 & GI,D & $\begin{array}{l}\text { cyclophilin-type peptidyl-prolyl } \\
\text { cis-trans isomerase }\end{array}$ & -1.9 & -2.4 \\
\hline 10110 & $\mathrm{M}, \mathrm{A}, \mathrm{Nu}$ & $\begin{array}{l}\text { carbamoyl-phosphate synthase, } \\
\text { large subunit }\end{array}$ & -4.4 & -2.4 \\
\hline 05910 & PS & phycobilisome linker polypeptide & -5.6 & -2.3 \\
\hline 03890 & $\mathrm{U}, \mathrm{O}$ & $\begin{array}{l}\text { putative dna protection during } \\
\text { starvation or oxidative stress }\end{array}$ & & \\
\hline & & transcription regulator protein & +3.0 & $-2.2 *$ \\
\hline 12543 & Ukn & hypothetical protein & +2.1 & $-2.2 *$ \\
\hline 12958 & PS & allophycocyanin alpha-B chain & -1.3 & -2.1 \\
\hline 01965 & $\mathrm{U}$ & ruberythrin & -7.7 & -1.1 \\
\hline
\end{tabular}


Table 3.4 (continued, pg 3 of 3 ):

\begin{tabular}{|c|c|c|c|c|}
\hline $\begin{array}{l}\text { WH570 } \\
\quad \text { ID }\end{array}$ & $\begin{array}{l}1 \text { KEGG } \\
\text { Function }\end{array}$ & $\begin{array}{l}4.4 \mathrm{pM} \mathrm{C} \\
\text { relativ }\end{array}$ & $\begin{array}{l}\mathrm{I}^{2+} \text { abundance } \\
\text { to control }\end{array}$ & $\begin{array}{l}44 \mathrm{pM} \mathrm{Cd}^{2+} \text { abundance } \\
\text { relative to control }\end{array}$ \\
\hline 13345 & M,pp & $\begin{array}{l}\text { ATP-dependent Clp protease } \\
\text { proteolytic subunit }\end{array}$ & -5.5 & -1.9 \\
\hline 01030 & GI, T & elongation factor EF-2 & -5.1 & -2.0 \\
\hline 14771 & Ukn & hypothetical protein & -3.7 & -2.0 \\
\hline 02844 & $\mathrm{M}, \mathrm{E}, \mathrm{C}, \mathrm{Chl}$ & $\begin{array}{l}\text { glyceraldehyde 3-phosphate } \\
\text { dehydrogenase (NADP+; } \\
\text { phosphorylating) }\end{array}$ & -3.7 & -1.5 \\
\hline 00735 & Ukn & hypothetical protein & -3.4 & +1.6 \\
\hline 09565 & Ukn & hypothetical protein & -3.3 & +1.5 \\
\hline 00840 & Ukn & hypothetical protein & -2.9 & +1.4 \\
\hline 02619 & $\mathrm{GI}, \mathrm{F}$ & molecular chaperone DnaK & -2.5 & +1.2 \\
\hline 02005 & U,A & glycine cleavage system $\mathrm{H}$ protein & -2.4 & +1.9 \\
\hline 15476 & U,Pd & $\begin{array}{l}\text { serine protease, trypsin family: } \\
\text { chemotrypsin serine protease }\end{array}$ & -2.2 & +1.1 \\
\hline 14806 & Ukn & hypothetical protein & -2.0 & +2.3 \\
\hline
\end{tabular}

Arranged in highest to lowest fold change, $44 \mathrm{pM} \mathrm{Cd}^{2+}$, then $4.4 \mathrm{pM} \mathrm{Cd}^{2+} .+=$ fold greater than control, $=$ fold less than control, $*=$ also in Table 3.3, $\mathrm{T}=$ translation, $\mathrm{GI}=$ genetic information processing, $\mathrm{C}=$ $\mathrm{CO}_{2}$ fixation, $\mathrm{PB}=$ purine biosynthesis, $\mathrm{St}=$ steroid hormone synthesis, $\mathrm{L}=$ lipid biosynthesis, $\mathrm{Cy}=$ cysteine metabolism, Met $=$ methionine synthesis, $\mathrm{Se}=$ selenoaminoacid synthesis, TCA $=$ TCA Cycle, $\mathrm{Po}$ $=$ porphyrin biosynthesis, $\mathrm{Chl}=$ chlorophyll biosynthesis, $\mathrm{Gly}=$ glycolosis, $\mathrm{N}=$ nitrogen, $\mathrm{PS}=$ photosynthesis, $\mathrm{P}=$ phosphate metabolism, $\mathrm{M}=$ metabolism, $\mathrm{A}=$ amino acid metabolism, $\mathrm{V}=$ vitamin metabolism, $\mathrm{Nu}=$ nucleic acid metabolsim, $\mathrm{E}=$ energy metabolism, $\mathrm{An}=$ ansamycin metabolism, $\mathrm{Si}=$ signaling, $\mathrm{U}=$ unclassified, $\mathrm{ABC}=$ membrane transport $\mathrm{ABC}$ type, $\mathrm{S}=$ sulfur metabolism, $\mathrm{Pp}=$ peptidase, $\mathrm{Mp}=$ membrane protein, $\mathrm{F}=$ protein folding, $\mathrm{Fe}=$ iron metabolism, $\mathrm{Tr}=$ transport, $\mathrm{En}=$ environmental sensing, $\mathrm{Cb}=$ carbohydrate metabolism, Ly = lysine synthesis, $\mathrm{Op}=$ oxidative phosphorylation, $\mathrm{Pd}=$ protein degradation.

\section{Global Proteomic Data - Pairwise by function and physiological effects}

When grouped by function, the proteomic response at different growth stages showed noticeable trends. This next section of the results and discussion groups proteins by function. All proteins discussed were differentially abundant between a $\mathrm{Cd}$ treatment and the control by $\geq$ two-fold. This section begins with the biosynthesis of chlorophyll, follows the energy path through photosynthesis and carbon fixation and then other metabolic processes. These functions are placed in the greater context of the three physiological observations: 1) similar growth rates among treatments despite $\mathrm{Cd}^{2+}$ addition (Figures 3.1 and 3.2a), 2) increased maximal chlorophyll $a$ fluorescence with $\mathrm{Cd}^{2+}$ addition (Figures 3.1 and $3.2 \mathrm{~b}$ ), and 3 ) increased mortality rates with $\mathrm{Cd}^{2+}$ addition 
(Figures 3.1 and 3.2c).

\section{Chlorophyll biosynthesis}

Five proteins involved in the biosynthesis of chlorophyll, a 17 step enzymatic process, were $\geq$ two-fold differentially abundant between the control and at least one of the $\mathrm{Cd}$ treatments during at least one of the growth phases (Figure 3.8). These five proteins are glutamate-1-semialdehyde transferase (Step 3), $\delta$-aminolevulinic acid dehydratase, also known as porphobilinogen synthase (Step 4), uroporphyrinogen decarboxylase (Step 7), coproporphyrinogen III oxidase (Step 8), and protochlorophyllide oxidoreductase (Step 16) (Figure 3.8).

Glutamate-1-semialdehyde transferase, which catalyzes the reaction of L-glutamic acid 1-semialdehyde to $\delta$-aminolevulinic acid in the presence of pyridoxal phosphate, was more abundant in the $44 \mathrm{pM} \mathrm{Cd}^{2+}$ treatment relative to the control during exponential growth (T1) and late stationary (T4) (Figure 3.8, Tables 3.1, II.5) and more abundant in the $4.4 \mathrm{pM} \mathrm{Cd}^{2+}$ treatment relative to the control during late stationary (T4) (Figure 3.8, Table II.5). Glutamate-1-semialdehyde transferase was more abundant in the control than both of the Cd treatments during very late stationary and death phase (Figure 3.8, Table $3.4)$.

$\delta$-aminolevulinic acid dehydratase, also known as porphobilinogen synthase, a Zn-requiring enzyme which catalyzes the reaction of $\delta$-aminolevulinic acid to porphobilinogen, was more abundant in the $44 \mathrm{pM} \mathrm{Cd}^{2+}$ treatment relative to the control during exponential growth (T1) (Figure 3.8, Tables 3.1) and more abundant in the control than both of the Cd treatments during late stationary (Figure 3.8, Table II.6).

Uroporphyrinogen decarboxylase, which catalyzes the reaction of uroporphyrinogen III to coproporphyrinogen III, was more abundant in the $44 \mathrm{pM} \mathrm{Cd}^{2+}$ treatment relative to the control during late stationary (T4) (Figure 3.8, Table II.5) and more abundant in the $4.4 \mathrm{pM} \mathrm{Cd}^{2+}$ treatment relative to the control during mid- and late stationary (T3 and T4) (Figure 3.8, Tables II.3, II.5). Uroporphyrinogen decarboxylase was more abundant in the control than both of the $\mathrm{Cd}$ treatments during early stationary (T2) (Figure 3.8, Table II.2). 

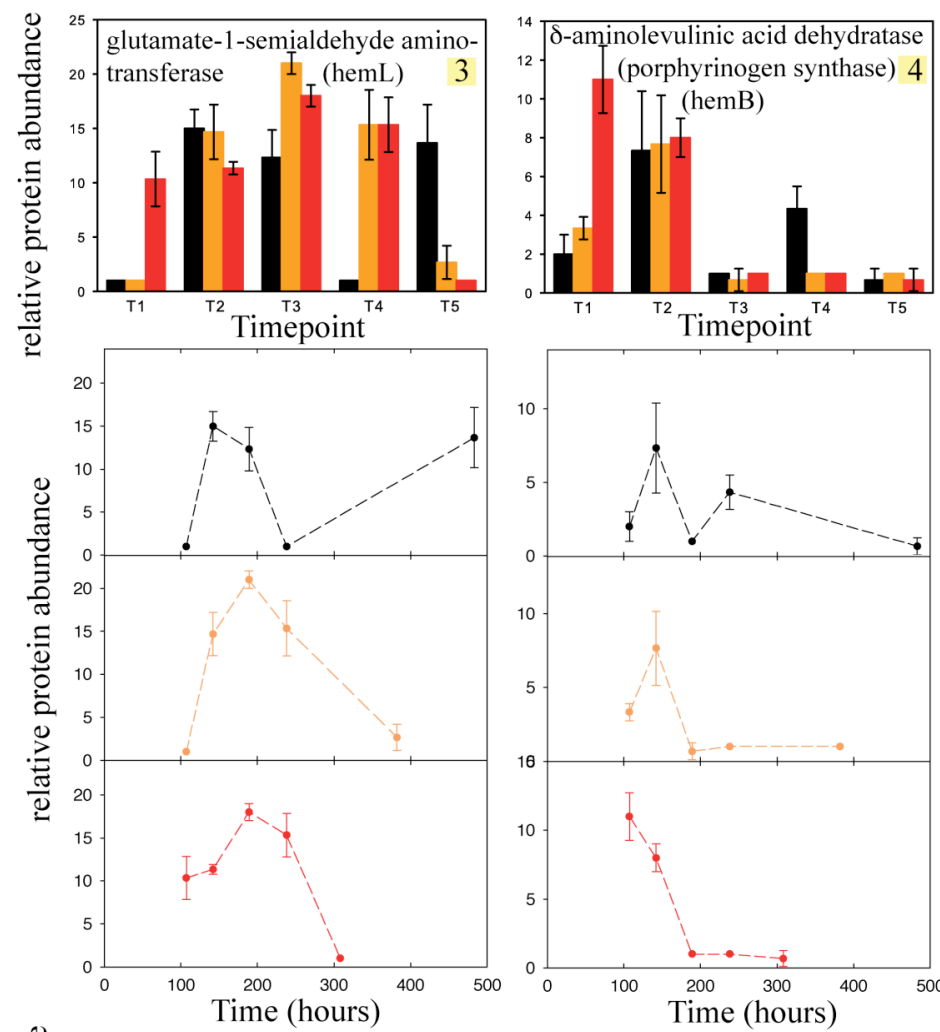

Figure 3.8: Relative protein abundances of chlorophyll biosynthesis proteins. Pathway from Blankenship 2002. Error bars representon standard deviation of triplicate injections.
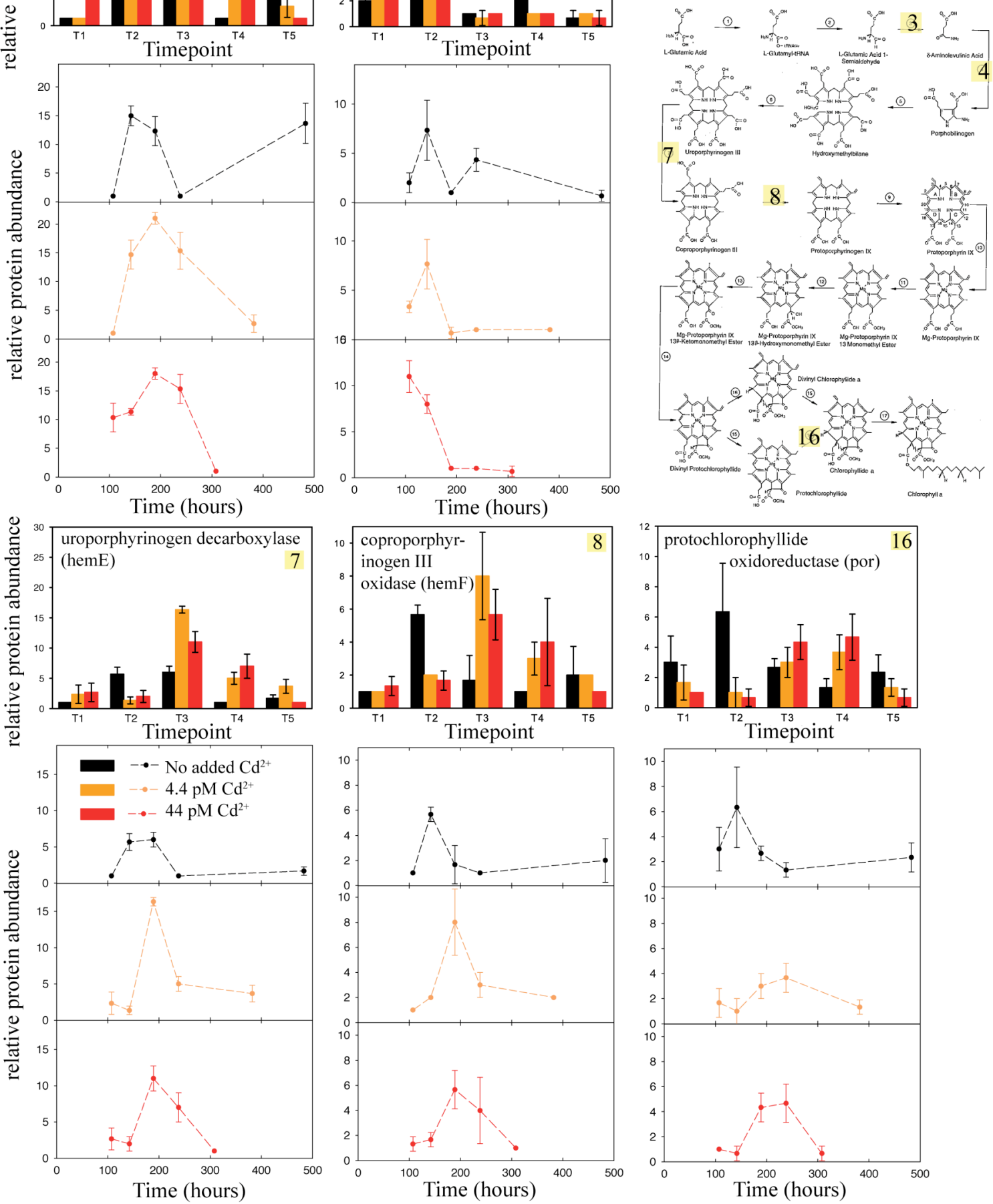
Coproporphyrinogen III oxidase, which catalyzes the reaction of coproporphyrinogen III to protoporphyrinogen IX, was more abundant in both the 4.4 and $44 \mathrm{pM} \mathrm{Cd}^{2+}$ treatment relative to the control during mid- and late stationary ( $\mathrm{T} 3$ and $\mathrm{T} 4$ ) (Figure 3.8, Tables II.3, II.5). Uroporphyrinogen decarboxylase was more abundant in the control than both of the Cd treatments during early stationary (T2) (Figure 3.8, Table II.1).

Protochlorophyllide oxidoreductase, which catalyzes the reaction of protochlorophyllide to chlorophyllide a, was more abundant in both the 4.4 and $44 \mathrm{pM}$ $\mathrm{Cd}^{2+}$ treatment relative to the control late stationary (T4) (Figure 3.8, Table II.5). Protochlorophyllide oxidoreductase was more abundant in the control than both of the $\mathrm{Cd}$ treatments during early stationary (T2) (Figure 3.8, Table II.2).

The dramatic physiological effects with chronic Cd exposure observed in this experiment (increased chlorophyll $a$ maximum and faster death rate in the $\mathrm{Cd}$ treatments) are not observed when $\mathrm{Zn}$ is added to the media (Figure 3.3). This may imply that the presence of $\mathrm{Zn}$ is integral to the photosynthetic functionality, perhaps by $\mathrm{Cd}$ disrupting a $\mathrm{Zn}$ regulatory system causing an induction of the chlorophyll biosynthesis pathway resulting in overproduction of chlorophyll. If this is true, we still do not know the exact mechanism or the site of this influence. The lack of dramatic physiological effects with $\mathrm{Cd}$ in the media when $\mathrm{Zn}$ is also present implies that the ratio of $\mathrm{Cd} / \mathrm{Zn}$ matters for toxicity of $\mathrm{Cd}$ to cyanobacteria in culture and consequently could play a role in the environment.

The origin of a physiological maximum in chlorophyll $a$ fluorescence at T4 (Figure 3.4a), late stationary phase, for the $44 \mathrm{pM} \mathrm{Cd}^{2+}$ treatment, because of an increased quantity of chlorophyll $a$ is supported by a greater than two-fold increase in relative abundance of glutamate-1-semialdehyde transferase, uroporphyrinogen decarboxylase and coporphyrinogen III oxidase, three enzymes in the chlorophyll $a$ biosynthesis pathway at T3 and T4 (Figures 3.4, 3.8, Tables II.3, II.5). The $4.4 \mathrm{pM} \mathrm{Cd}^{2+}$ treatment also reached a similar maximum fluorescence in-between protein sampling points $\mathrm{T} 4$ and $\mathrm{T} 5$ and has the same more than two-fold relative increase in these three 
enzymes. This hypothesis is not supported in that the chlorophyll $a$ fluorescence per cell with time (a proxy for chlorophyll $a$ per cell) does not show much difference between the control and Cd treatments (plot not shown).

Two similar alternative hypotheses hinge on the fact that a change in chlorophyll $a$ fluorescence directly reflects photosystem II, as expected in most photosynthetic organisms (Campbell et al., 1998). However, due to the ability of cyanobacteria to adapt chromically (Everroad et al., 2006), the slight contribution of phycobiliproteins to the chlorophyll emission spectrum (Campbell et al., 1998), and the possible slight contribution of photosystem I chlorophyll (Campbell et al. 1998 and reference therein), one cannot always assume this direct correlation of chlorophyll $a$ fluorescence with photosystem II. Although chromic adaptation of many strains of marine Synechococcus has been investigated by Palenik (2001), whether or not WH5701 is capable of chromic adaptation is as of yet unknown. The first hypothesis is that $\mathrm{Cd}$ directly binds to photosystem II centers causing an increase in chlorophyll $a$ fluorescence. Addition of 3(3,4-dichlorophenyl)-1,1-dimethylurea (DCMU) to cyanobacteria causes the closing of photosystem II centers, resulting in a rapid rise in fluorescence (Campbell et al., 1998). This hypothesis cannot be tested by this global proteomic dataset. The second hypothesis is that Cd disrupts or reduces electron transport, based on the pot model of Beutler 2003 and related evidence of $\mathrm{Zn}^{2+}$ and $\mathrm{Cd}^{2+}$ binding to the bacterial reaction center in Rhodobacter sphaeroides thereby reducing rates of electron transfer from photosystem II

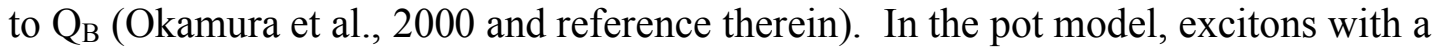
particular intensity produced by absorbed light energy strike photosystem II. There are three subsequent means of deexcitation: photochemical quenching, fluorescence, and thermal deexcitation. If an increase in fluorescence is observed, assuming a constant input and no change in photosystem II, then photochemical quenching leading to the electron transport train or thermal deexcitation must be reduced. This could be tested by global proteomics by comparing the relative abundances if the cytochrome $b_{6} f$ complex or enzymes involved in the synthesis of quinone were detected, but these enzymes were not observed. 
Alternatively, the in vivo substitution of the $\mathrm{Mg}^{2+}$ binding in chlorophyll by heavy metals (mercury, copper, cadmium, nickel, zinc, and lead), leading to the breakdown of photosynthesis in plants, has been shown to be an important damage mechanism (Küpper et al., 1998). The substitution of $\mathrm{Cd}$ or $\mathrm{Zn}$ for magnesium in chlorophyll destabilizes the first excitation state, as deduced by lowered in vitro fluorescence quantum yield of heavy metal substituted chlorophylls compared to magnesium chlorophyll (Küpper et al., 1998). There has been one known photosynthetically active Zn-bacteriochlorophyll in Acidiphilium rubrum (Wakao et al., 1996). The substitution of the magnesium in chlorophyll with $\mathrm{Cd}$ is probably not what is happening in this experiment because we would expect the chlorophyll $a$ fluorescence to decrease, due to the instability of $\mathrm{Cd}$ chlorophyll (Küpper et al., 1996), not increase as we observed. Or because the heavy metal substitution rate in plants is only about $2 \%$ for the total chlorophyll, albeit this substitution rate still produces a massive breakdown in photosynthesis (Küpper et al., 1998), substitution could be happening in this experiment and it would undetected.

Cd caused some changes in chlorophyll $a$ biosynthesis proteins in this experiment, but we have not shown this to be directly linked to an increase in chlorophyll $a$ itself. The chlorophyll $a$ maximum is probably related to $\mathrm{Cd}$ interfering with $\mathrm{Zn}$ because we do not see the chlorophyll $a$ maximum when $\mathrm{Zn}$ is added to the media (Figure 3.3). Cd could be interfering with $\mathrm{Zn}$ regulation. $\mathrm{Zn}$ could be involved in photosynthetic regulation and $\mathrm{Cd}$ is interfering. Oxidative stress is known to modulate apoptosis. Apoptosis is the process of programmed cell death in animal systems and apoptotic processes have begun to be considered in phytoplankton (Vardi et al., 2007). If $\mathrm{Zn}$ is modulating oxidative stress and the cells are $\mathrm{Zn}$ deficient, $\mathrm{Cd}$ can be affecting oxidative stress, which may cause cell death. There is also a dosage of $\mathrm{Cd}$ and time effect. Cells exposed to an order of magnitude more $\mathrm{Cd}, 44 \mathrm{pM} \mathrm{Cd}^{2+}$ show the effects first and cell numbers dramatically decrease and then the cells exposed to $4.4 \mathrm{pM} \mathrm{Cd}^{2+}$ show similar effects later in the experiment and then cell numbers decrease dramatically (Figure $3.4 a, b)$. 


\section{Phycobilisome}

Phycobilisomes gather excitation energy from incoming photons. The proteins that comprise phycobilisomes comprise a large percentage of the total protein mass in a cyanobacterial cell, and indeed we see phycocyanin and allophycocyanin as the most abundant proteins in our global proteomic data. In phycobilisomes, phycobiliproteins bind phycobilins (chromophores) by covalent thioether bonds to cysteinyl residues (MacColl, 1998; Everroad et al., 2006). Phycobilisomes are thought to be able to transfer excitation energy to both photosystem II and I (Mullineaux, 1999). Four phycobilisomeassociated proteins: the $\alpha$ subunit of phycocyanin, $\beta$ subunit of allophycocyanin, anchor polypeptide $\mathrm{L}_{\mathrm{CM}}$ and phycobilisome linker polypeptide were more than two-fold differentially abundant between the control and at least one of the $\mathrm{Cd}$ treatments at one of the time points (Figure 3.9).

The $\alpha$ subunit of phycocyanin, the outer rod in the phycobilisome, was overall the most abundant protein identified in this experiment. The $\beta$ subunit of allophycocyanin, a core component in the phycobilisome, was the third most abundant protein identified. During late stationary phase (T4), these two pigments were more abundant in the two Cd treatments than the control (Figure 3.9, Table II.5). During very late stationary/death phase, phycocyanin and allophycocyanin were more abundant in the control than the two Cd treatments (Figure 3.9, Table 3.4).

The anchor polypeptide $\mathrm{L}_{\mathrm{CM}}$, another core component of the phycobilisome, was more abundant in both of the Cd treatments during exponential growth (T1) and more abundant in the control than the two $\mathrm{Cd}$ treatments during very late stationary/death phase (T5) (Figure 3.9, Tables 3.1, 3.4).

The phycobilisome linker polypeptide, peptides that link together the discs of pigments, is more abundant in the control than the $44 \mathrm{pM} \mathrm{Cd}^{2+}$ treatment during early and mid-stationary and very late stationary/death (T2, T3, T5) (Figure 3.9, Tables II.3, II.4, 3.4). The linker polypeptide is more abundant in the control than the $4.4 \mathrm{pM} \mathrm{Cd}^{2+}$ during very late stationary/death (T5) (Figure 3.9, Table 3.4). 

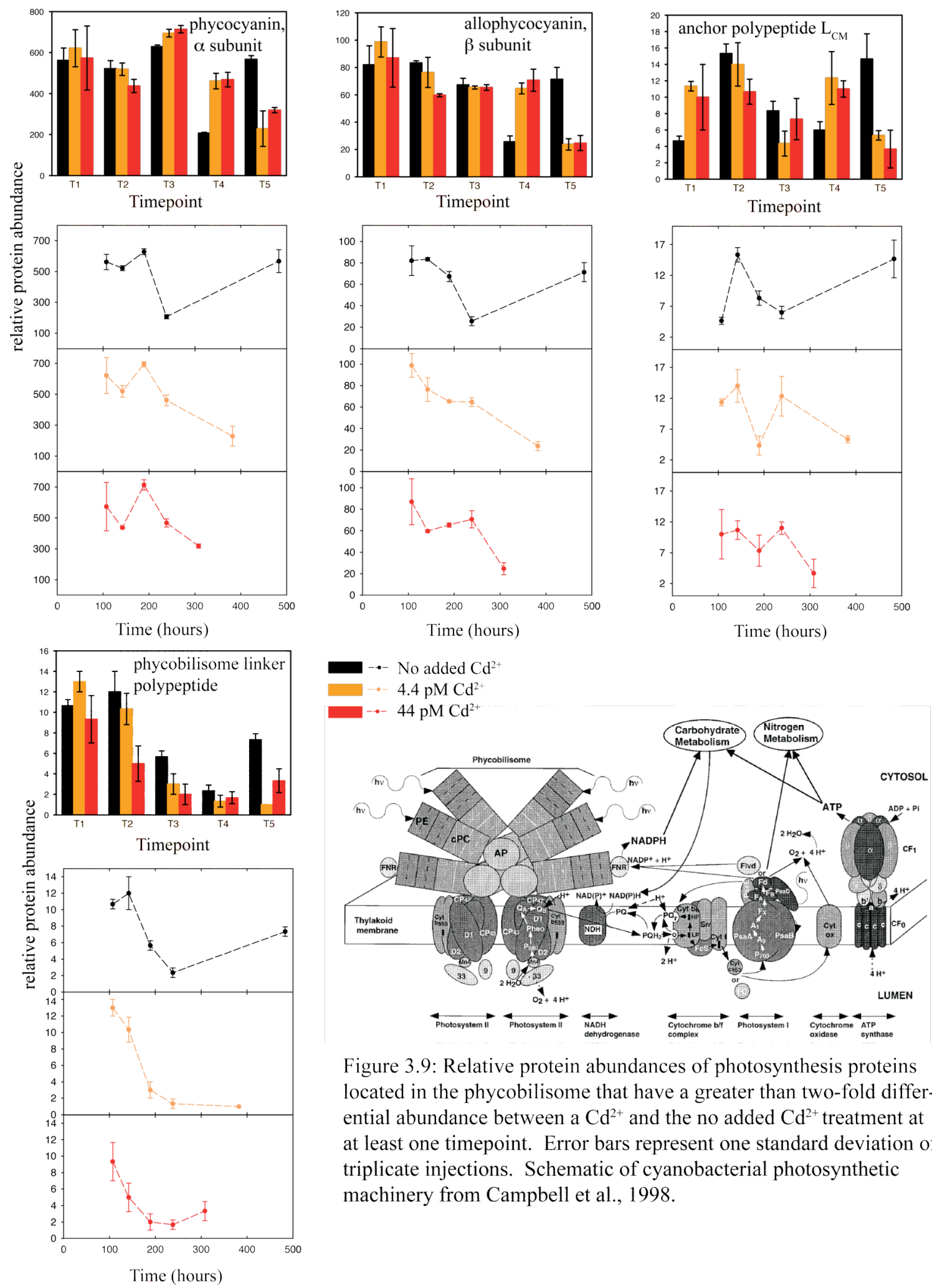

Figure 3.9: Relative protein abundances of photosynthesis proteins located in the phycobilisome that have a greater than two-fold differential abundance between a $\mathrm{Cd}^{2+}$ and the no added $\mathrm{Cd}^{2+}$ treatment at at least one timepoint. Error bars represent one standard deviation of triplicate injections. Schematic of cyanobacterial photosynthetic machinery from Campbell et al., 1998. 
Chronic Cd exposure in both the $4.4 \mathrm{pM} \mathrm{Cd}^{2+}$ and $44 \mathrm{pM} \mathrm{Cd}^{2+}$ treatments caused a three-fold increase in the rate of the degradation of pigments in the phycobilisome relative to the control as calculated by the decrease in spectral counts of phycocyanin $\beta$ subunit (calculated from Figure 3.9). The mechanism causing the faster degradation of pigments in the $\mathrm{Cd}$ treatments is unknown. One possibility is the direct binding of $\mathrm{Cd}$ to the covalent thioether bonds to cysteinyl residues that link phycobiliproteins to phycobilins (Everroad et al., 2006) causing degradation of the protein, another possibility assumes phycobiliproteins are continually made, but allocation of sulfur to other processes in the cell, such as production of low molecular weight thiols or metallothioneins, would make sulfur unavailable for use in synthesis of phycobiliproteins. This suggestion of lack of accessible sulfur combined with the observed increase in relative abundance of arylsulfatases, enzymes that scavenge sulfur from organo-sulfur compounds in times of low sulfate abundance, could be taken to imply that the cells are experiencing sulfur starvation. In this instance, however, sulfur starvation would have to be a result of phosphate limitation, because there is $\mathrm{mM}$ sulfate in the media. Sulfate uptake transport systems tend to require ATP (Silver and Walderhaug, 1992). In addition, the loss of pigmentation, as evidenced by the lower abundance of phycocyanin and allophycocyanin in $\mathrm{Cd}$ treatments compared to the control during very late stationary/death phase, (T5) agrees well with the lower cell counts attributable to cell death in the cultures. 


\section{Photosystem II}

Phycobilisomes are thought to transfer excitation energy to photosystem II (PSII), but also photosystem I (Mullineaux, 1999). Three PSII proteins: PSII protein (PsbC), PSII Mn-stabilizing polypeptide, PSII chlorophyll binding protein, and a protein annotated as "chloroplast membrane associated protein $30 \mathrm{kD}$ protein-like" were more than two-fold differentially abundant between the control and at least one of the $\mathrm{Cd}$ treatments at one of the timepoints (Figure 3.10).

PSII protein (PsbC) and the PSII chlorophyll binding protein were more abundant in the control and $4.4 \mathrm{pM} \mathrm{Cd}^{2+}$ than the $44 \mathrm{pM} \mathrm{Cd}^{2+}$ during exponential growth (T1) (Figure 3.10, Table 3.2) and more abundant in the control than the Cd treatments during early stationary (T2) (Figure 3.10, Table 3.2). The PSII Mn-stabilizing polypeptide, involved in PSII water oxidation, was more abundant in the control and $4.4 \mathrm{pM} \mathrm{Cd}^{2+}$ than the $44 \mathrm{pM} \mathrm{Cd}^{2+}$ during T1 (Figure 3.10, Table 3.2). The protein annotated as "chloroplast membrane associated 30kD protein-like" was more abundant in the control than the $44 \mathrm{pM} \mathrm{Cd}^{2+}$ treatment during $\mathrm{T} 1$ (Figure 3.10, Table 3.2) and more abundant in the control than both Cd treatments during late stationary (T4) (Figure 3.10, Table II.6). During very late stationary/death (T5), however, it is more abundant in the $44 \mathrm{pM} \mathrm{Cd}^{2+}$ treatment than both the control and the $4.4 \mathrm{pM} \mathrm{Cd}^{2+}$ treatment (Figure 3.10, Table 3.3).

Besides the aforementioned PSII Mn-stabilizing protein, chlorophyll-binding protein and $\mathrm{PsbC}$, which were lower in abundance in the $\mathrm{Cd}$ treatments compared to the control during growth, three other components of PSII were detected whose relative abundances either were too low or did not change dramatically between the control and $\mathrm{Cd}$ treatments. The fact that the PSII proteins with greater than 5 spectral counts have similar relative abundances in the $\mathrm{Cd}$ treatments compared to the control throughout the experiment implies that a portion of the core part of PSII does not appear to be affected by $\mathrm{Cd}$. This is consistent with the reduced electron transport causing the increase in chlorophyll fluorescence. Studies have shown the direct binding of $\mathrm{Cd}^{2+}$ to core proteins of PSII thereby reducing electron transport (Okamura et al., 2000). PSII is comprised of D1 and D2 reaction center core proteins, CP43 (a chlorophyll $a$ binding core antenna 
protein associated with the reaction center), an oxygen-evolving complex and cytochrome b559. Under acclimation to low growth light, functional PSII content is approximately equal to the D1 protein content (Six et al., 2007) from (Burns et al., 2006). D1 was not observed, but core protein D2 was detected with at most three spectral counts, the fact that it is detected means this protein could be quantified using labeled peptides using a triple quadrupole mass spectrometer, which can target a specific mass range. The other two proteins had similar relative abundances among $\mathrm{Cd}$ treatments compared to the control: PSII complex extrinsic protein precursor (PsuB) and a putative PSII reaction center Psb28 with counts up to 42 and 19 respectively.

The PSII Mn-stabilizing polypeptide, involved in PSII water oxidation, was more abundant in the control and $4.4 \mathrm{pM} \mathrm{Cd}^{2+}$ than the $44 \mathrm{pM} \mathrm{Cd}^{2+}$ during T1 (Figure 3.10, Table 3.2). Because this protein is less abundant in the $44 \mathrm{pM} \mathrm{Cd}^{2+}$ treatment, $\mathrm{Cd}$ could be interfering with the stabilization of Mn. Perhaps the evolution of oxygen is similar or decreased in the $44 \mathrm{pM} \mathrm{Cd}^{2+}$ treatment compared to the control and $4.4 \mathrm{pM} \mathrm{Cd}^{2+}$ treatments, which could help to explain why an increase in oxidative stress related proteins with chronic Cd was not observed, as previously noted in Chlamydomonas reinhardtii (Gillett et al., 2006), until stationary phase if at all.

Similar to some carboxysome-associated proteins, like the possible carbon concentrating mechanism, the carboxysome shell peptide, and the carboxysome shell protein, the protein annotated as "chloroplast membrane associated $30 \mathrm{kD}$ protein-like" is more abundant in the control than the $44 \mathrm{pM} \mathrm{Cd}^{2+}$ treatment during $\mathrm{T} 1$ (Figure 3.13, Table 3.2) and more abundant in the $44 \mathrm{pM} \mathrm{Cd}^{2+}$ treatment than both the control and the $4.4 \mathrm{pM} \mathrm{Cd}^{2+}$ treatment during T5 (Figure 3.13, Table 3.3). This could imply some sort attempt at carbon fixation in the $44 \mathrm{pM} \mathrm{Cd}^{2+}$ treatment while the cells are lysing or perhaps the production of these proteins is upregulated by the combination of $\mathrm{Cd}$ exposure and cell death. In addition, many PSII proteins can be removed and yet render PSII still functional (Blankenship, 2002). Knowing this, the lack of PsbC and the PSII chlorophyll binding protein in the $44 \mathrm{pM} \mathrm{Cd}^{2+}$ treatment does not mean that PSII is nonoperational, perhaps merely less effective. 

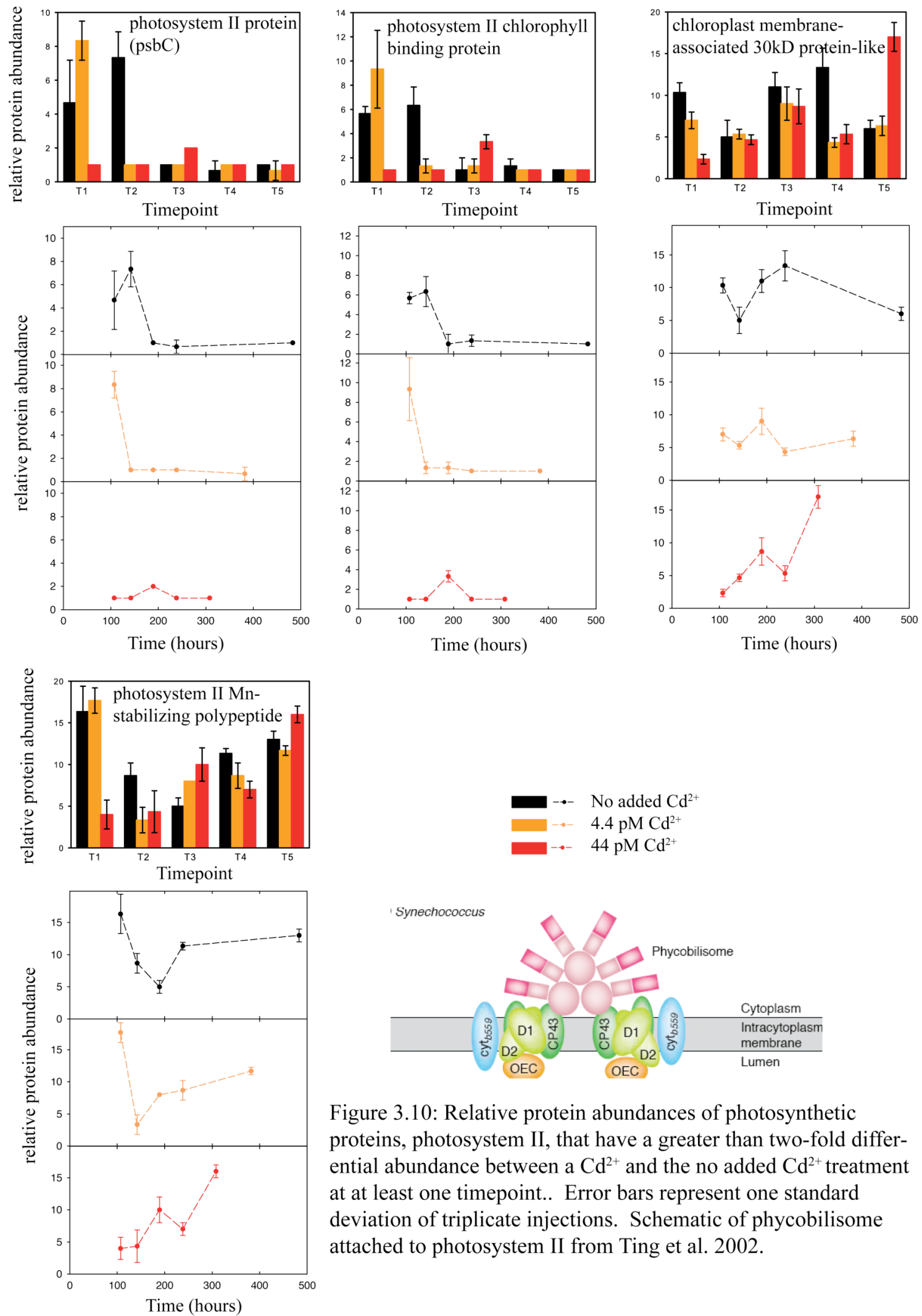

Figure 3.10: Relative protein abundances of photosynthetic proteins, photosystem II, that have a greater than two-fold differential abundance between a $\mathrm{Cd}^{2+}$ and the no added $\mathrm{Cd}^{2+}$ treatment at at least one timepoint.. Error bars represent one standard deviation of triplicate injections. Schematic of phycobilisome attached to photosystem II from Ting et al. 2002. 


\section{Photosystem I}

Electrons are transferred from PSII to photosystem I (PSI). The cyclic flow of electrons through PSI generates a $\mathrm{H}^{+}$gradient across the thylakoid membrane, which is used to generate ATP using ATP synthase. Some of the most dramatic differences in relative protein abundance between the treatments are observed in PSI proteins. Five PSI proteins: core protein (PsaB), subunit III (PsaF), reaction center subunit II (PsaD), reaction center subunit IV (PsaE), and reaction center subunit VII (PsaC), were more than two-fold differentially abundant between the control and at least one of the Cd treatments at one of the timepoints (Figure 3.11).

PSI proteins, core protein PsaB and subunit III (PsaF) are more abundant in the control and $4.4 \mathrm{pM} \mathrm{Cd}^{2+}$ than the $44 \mathrm{pM} \mathrm{Cd}^{2+}$ treatment during exponential growth (T1) (Figure 3.11, Table 3.2). They are more abundant in the control than both Cd treatments during early stationary (T2) (Figure 3.11, Table II.2). They are similarly not abundant among all treatments throughout the remainder of stationary phase T3, T4, and T5 (Figure 3.11).

PSI reaction centers subunits II (PsaD) and IV (PsaE) are more abundant in the control and $4.4 \mathrm{pM} \mathrm{Cd}^{2+}$ than the $44 \mathrm{pM} \mathrm{Cd}^{2+}$ treatment during exponential growth (T1) (Figure 3.11, Table 3.2). They are more abundant in the control than both Cd treatments during late stationary (T4) (Figure 3.11, Table II.6). During very late stationary/death (T5), however, they are more abundant in the $44 \mathrm{pM} \mathrm{Cd}^{2+}$ treatment than both the control and the $4.4 \mathrm{pM} \mathrm{Cd}^{2+}$ treatment (Figure 3.11, Table 3.3).

PSI reaction center subunit VII (PsaC) is more abundant in the control and $4.4 \mathrm{pM}$ $\mathrm{Cd}^{2+}$ than the $44 \mathrm{pM} \mathrm{Cd}^{2+}$ treatment during exponential growth (T1) (Figure 3.11, Table 3.2). It is more abundant in the control than both $\mathrm{Cd}$ treatments during early and late stationary (T2 and T4) (Figure 3.11, Tables II.2, II.6). During very late stationary/death (T5), however, it is more abundant in the $44 \mathrm{pM} \mathrm{Cd}^{2+}$ treatment than both the control and the $4.4 \mathrm{pM} \mathrm{Cd}^{2+}$ treatment (Figure 3.11, Table 3.3).

The lower relative abundance of five PSI proteins during exponential growth phase in the $44 \mathrm{pM} \mathrm{Cd}^{2+}$ treatment than both the control and the $4.4 \mathrm{pM} \mathrm{Cd}^{2+}$ treatment 
(Figure 3.11, Table 3.2) suggests that there is a threshold between 4.4 and $44 \mathrm{pM} \mathrm{Cd}^{2+}$ that affects the presence of PSI proteins. More Cd may be taken up faster because it is more abundant. For example, at T1, there is less of PsaB and PsaF in $44 \mathrm{pM} \mathrm{Cd}^{2+}$ treatment, whereas at T2 there is more of PsaB and PsaF in the control than both of the $\mathrm{Cd}$ treatments. This suggests that the threshold was reached in the $4.4 \mathrm{pM} \mathrm{Cd}^{2+}$ treatment by $\mathrm{T} 2$. 

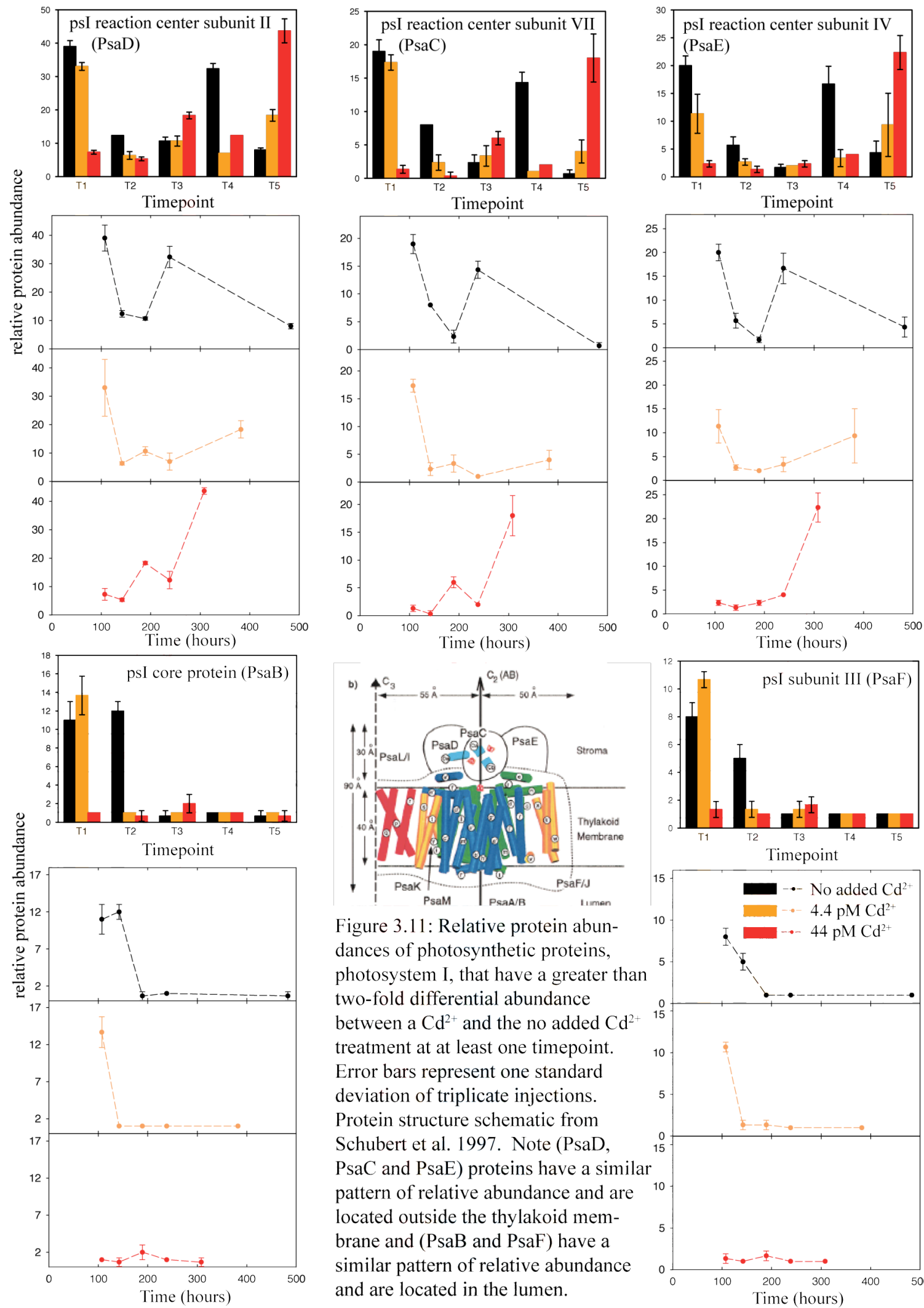

Figure 3.11: Relative protein abundances of photosynthetic proteins, photosystem I, that have a greater than two-fold differential abundance between a $\mathrm{Cd}^{2+}$ and the no added $\mathrm{Cd}^{2+}$ treatment at at least one timepoint. Error bars represent one standard deviation of triplicate injections. Protein structure schematic from Schubert et al. 1997. Note (PsaD, PsaC and PsaE) proteins have a similar pattern of relative abundance and are located outside the thylakoid membrane and (PsaB and PsaF) have a similar pattern of relative abundance and are located in the lumen.

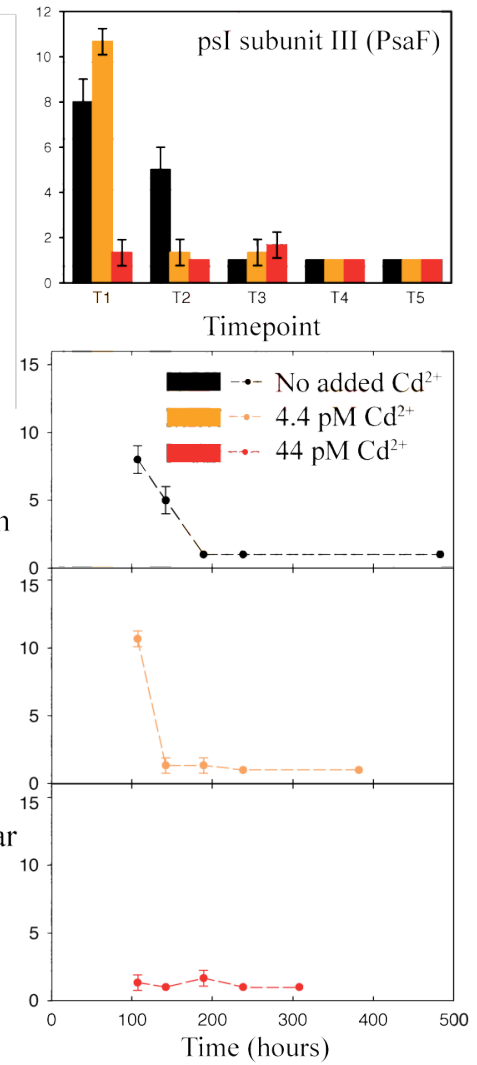


The pattern of distribution of PSI proteins in the $44 \mathrm{pM} \mathrm{Cd}^{2+}$ treatment suggests that overall, PSI is less abundant per cell during growth and stationary phase and more abundant during death phase, similar to some of the carboxysome-associated proteins. Perhaps the presence of $\mathrm{Cd}$ in the quantities supplied in the $44 \mathrm{pM} \mathrm{Cd}^{2+}$ treatment blocks, inhibits or reduces the abundance of PSI proteins, leading to the eventual demise of the cell. Perhaps the death of the cells in the Cd treatments or the presence of $\mathrm{Cd}$ itself triggers the upregulation of photosynthesis and carbon fixation proteins. The stoichiometry of PSI to PSII in cyanobacteria is usually higher than $1: 1$, but can vary (Campbell et al., 1998). This idea of the reduction of cellular levels of PSI in response to metal stress is not unique; two strains of freshwater cyanobacteria grown under irondepleted conditions reduce the cellular levels of PSI and target the phycobilisome for rapid degradation (Ting et al., 2002 and references therein). Both of these effects are observed in this iron-replete $\mathrm{Cd}$-addition experiment. One could argue that an overabundance of $\mathrm{Cd}$ apparently displays some characteristics of a cellular iron depletion. In addition, alternative electron sinks and transport upstream of PSI involving $\mathrm{O}_{2}$ as a major acceptor in Synechococcus WH8102 (Bailey et al., 2008) shows that an open ocean marine cyanobacterium could adjust to a changing PSI to PSII ratio, so adjustments in cellular PSI/PSII ratios hinted at by these changes in relative protein abundance is consistent with observations of previous researchers.

Cadmium appears to either be interfering with the regulatory network that controls the production of lumen-associated proteins, or be interfering directly with PSI proteins inside the lumen. If the former were the case, the regulator has not yet been found. If the latter were true, the question of the $\mathrm{Cd}^{2+}$ transfer mechanism across the lumen membrane arises.

A rise in relative protein abundances of stromal side PSI proteins with a decrease in pigmentation could be related to regulation. PsaD, PsaC and PsaE proteins after T3 are inversely correlated with the relative abundance of pigments, phycocyanin and allophycocyanin, whereas PsaB and PsaF appear not to be perhaps due to lower abundance (Figure 3.11). The control shows a drop in pigmentation at $\mathrm{T} 4$ and the $\mathrm{Cd}$ 
treatments show a drop in pigmentation at T5, with corresponding rises in relative protein abundances of PsaD, PsaC and PsaE.

Three of the PSI proteins (PsaD, PsaC and PsaE) have a similar pattern of relative abundance and are located outside the thylakoid membrane. Proteins located in the thylakoid membrane, PsaB and PsaF, have a similar pattern of relative abundance and are located on the lumen side of the thylakoid membrane (Figure 3.11). The Mn-containing oxygen evolving complex of PSII is also located on the lumen side (Figure 3.10), so either the whole complex containing the manganese is assembled in the lumen, or the protein and the $\mathrm{Mn}$ are transported to the lumen separately and assembled. The transport of $\mathrm{Cd}^{2+}$ with $\mathrm{Mn}^{2+}$ systems across the outer membrane of eukaryotic diatoms has been observed (Sunda and Huntsman, 2000), related evidence for possible interactions of $\mathrm{Cd}^{2+}$ and $\mathrm{Mn}^{2+}$. Related evidence for the direct interference of $\mathrm{Cd}$ on photosynthetic apparatus comes from a study with spinach. Cd and other heavy metals can directly replace for metals in the photosynthetic apparatus, thereby affecting photosynthesis (Sujak et al., 2005). The number of copper plastocyanins can decrease, which causes a decrease in turnover of the cytochrome $b_{6}$ f electron complex, affecting the electron transfer path to PSI (Sujak et al., 2005).

\section{Ferredoxin and ATP synthase}

Electrons are transferred from photosystem I to ferredoxin and used by ATP synthase to make adenine triphosphate (ATP). Three ferredoxins: ferredoxin-NADP reductase, a possible ferredoxin $(2 \mathrm{Fe}-2 \mathrm{~S})$, and ferredoxin-thioredoxin reductase catalytic chain and three subunits of ATP synthase were more than two-fold differentially abundant between the control and at least one of the $\mathrm{Cd}$ treatments at at least one of the timepoints (Figure 3.12).

Ferredoxin-NADP reductase was more abundant in the control than both of the Cd treatments during early stationary (T2) (Figure 3.12, Table II.2). It was more abundant in the control than the $44 \mathrm{pM} \mathrm{Cd}^{2+}$ treatment during very late stationary/death (T5) (Figure 3.12, Table 3.4). Ferredoxin NADP reductase was more abundant in both the Cd treatments than the control during late stationary (T4) (Table II.5). 
A possible ferredoxin $(2 \mathrm{Fe}-2 \mathrm{~S})$ was more abundant in the control and the $4.4 \mathrm{pM}$ $\mathrm{Cd}^{2+}$ treatment than the $44 \mathrm{pM} \mathrm{Cd}^{2+}$ treatment during exponential growth (T1) (Figure 3.12, Table 3.2). It was more abundant in the control than both the $\mathrm{Cd}$ treatments during late stationary (T4) (Figure 3.12, Table II.6). It was more abundant in the $44 \mathrm{pM} \mathrm{Cd}^{2+}$ than either the control or $4.4 \mathrm{pM} \mathrm{Cd}^{2+}$ during very late stationary/death (T5) (Figure 3.12, Table 3.4). The relative protein abundance distribution this possible ferredoxin (2Fe-2S) is very similar to that of carboxysome-associated proteins, suggesting similar regulation (Figure 3.13).

A ferredoxin-thioredoxin reductase catalytic chain protein was more abundant in the control and the $4.4 \mathrm{pM} \mathrm{Cd}^{2+}$ treatment than the $44 \mathrm{pM} \mathrm{Cd}^{2+}$ treatment during early stationary (T2) (Figure 3.12, Table II.2). It was more abundant in the control than both of the Cd treatments during late stationary (T4) (Figure 3.12, Table II.6). This pattern suggests that the catalytic chain was inhibited by $44 \mathrm{pM} \mathrm{Cd}^{2+}$ during growth phase and the inhibition by $4.4 \mathrm{pM} \mathrm{Cd}^{2+}$ came later, perhaps after enough $\mathrm{Cd}$ built up inside the cells.

ATP synthase subunit A was more abundant in the $4.4 \mathrm{pM} \mathrm{Cd}^{2+}$ treatment than the $44 \mathrm{pM} \mathrm{Cd}^{2+}$ treatment during exponential growth (T1) (Figure 3.12). It was more abundant in the control than both of the $\mathrm{Cd}$ treatments during early and late stationary (T2 and T4) (Figure 3.12, Tables II.2, II.6). It was more abundant in both Cd treatments than the control during very late stationary/death (T5) (Figure 3.12, Table 3.3).

ATP synthase subunit B was more abundant in the control and the $4.4 \mathrm{pM} \mathrm{Cd}^{2+}$ treatment than the $44 \mathrm{pM} \mathrm{Cd}^{2+}$ treatment during exponential growth (T1) (Figure 3.12, Table 3.2). It was more abundant in the control than both of the $\mathrm{Cd}$ treatments during early and late stationary (T2 and T4) (Figure 3.12, Tables II.2, II.6). It was more abundant in the $44 \mathrm{pM} \mathrm{Cd}^{2+}$ treatment than the control during very late stationary/death (T5) (Figure 3.12, Table 3.3).

ATP synthase subunit $\mathrm{C}$ was more abundant in the control and the $4.4 \mathrm{pM} \mathrm{Cd}^{2+}$ treatment than the $44 \mathrm{pM} \mathrm{Cd}^{2+}$ treatment during exponential growth (T1) (Figure 3.12, Table 3.2). It was more abundant in the control than both of the $\mathrm{Cd}$ treatments during 
early and late stationary (T2 and T4) (Figure 3.12, Tables II.2, II.6). ATP synthase is a protein complex comprised of multiple subunits responsible for the synthesis of ATP. In the control, ATP synthase is relatively constant to slightly decreasing T1-T3, highly abundant in T4 and not very abundant in T5. Overall, it appears that ATP synthase is less abundant in the $44 \mathrm{pM} \mathrm{Cd}^{2+}$ treatments, suggesting inhibition by $\mathrm{Cd}$. As with the ferredoxin-thioredoxin reductase catalytic chain, inhibition in the $4.4 \mathrm{pM} \mathrm{Cd}^{2+}$ treatment occurred later in the experiment as inhibition in the $44 \mathrm{pM} \mathrm{Cd}^{2+}$, suggesting inhibition after Cd buildup in the cells. 

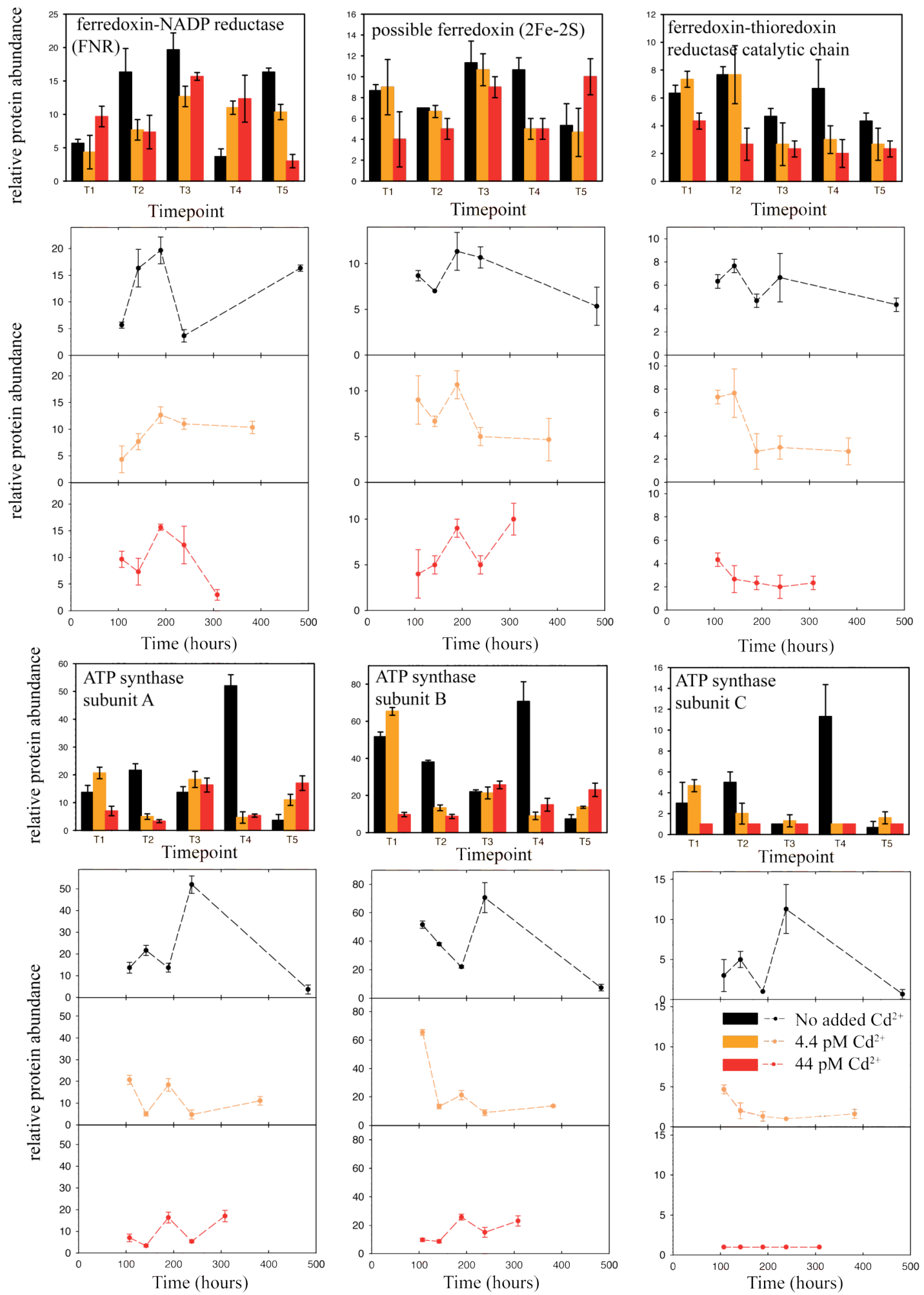

Figure 3.12: Relative protein abundances of photosynthetic proteins, ferredoxin and ATP synthase, that have a two-fold or greater differential abundance between a $\mathrm{Cd}^{2+}$ and the no added $\mathrm{Cd}^{2+}$ treatment at at least one timepoint. Error bars represent one standard deviation of triplicate injections. 
During stationary phase from $\mathrm{T} 3$ to $\mathrm{T} 4$ in a $\mathrm{Zn}$-deprived culture with no $\mathrm{Cd}^{2+}$ added, there was a temporary decrease of phycocyanin (Figure 3.9, Table II.5) and PSII protein (Figure 3.10) abundances with a concurrent increase in PSI protein abundances (Figure 3.11), carboxysome-associated proteins (Figure 3.13), and ATP synthase (Figure 3.12) suggesting that the PSI/PSII ratio increased with a concurrent increase in the production of ATP and carboxysome-associated carbon fixation. There was an unexpected decrease in the phycocyanin relative abundance in the control treatment during late stationary phase (T4) (Figure 3.9). Phycocyanin spectral counts drop from $\sim 600$ at T3 to $\sim 200$ at T4 and spike back up to $\sim 600$ at T5. This sample was colored yellow when extracted as opposed to the usual blue from phycocyanin, consistent with the lowered phycocyanin relative abundances. It is tempting to dismiss this control sample as an outlier, but three lines of evidence support the idea that it is not an outlier, but rather associated with a minor cell death incident: 1) There is an factor of 1.9 decrease in cell number from T3 to T4 suggesting cell death, 2) cluster analysis of the global protein data group the $\mathrm{T} 4$ no added $\mathrm{Cd}$ treatment with $\mathrm{T} 5 \mathrm{Cd}$ treatments, which were experiencing cell death, and 3) many of the relative abundance distributions of other proteins make sense in their overall distributions i.e. they do not have unexpected spectral counts at T4. Proteins with spectral count distributions consistent with the rest of the timepoints are: possible ferredoxin (Figure 3.12); ferredoxin-thioredoxin reductase catalytic chain (Figure 3.12); ribulose 1,5 bisphosphate carboxylase (Figure 3.13); Sadenosylmethionine synthetase (Figure 3.16); rehydrin (Figure 3.17) and superoxide dismutase (Figure 3.17), among others. Proteins with abundances that decrease dramatically with phycocyanin in the no added $\mathrm{Cd}$ at $\mathrm{T} 4$ are: allophycocyanin (Figure 3.9); ferredoxin-NADP reductase (Figure 3.12); malate oxidoreductase (Figure 3.14); aspartate aminotransferase (Figure 3.14); glyceraldehydes-3-phosphate dehydrogenase (Figure 3.14); transketolase (Figure 3.14); phosphoglycerate kinase (Figure 3.14); arylsulfatase (Figure 3.15) and cysteine synthase A (Figure 3.16), among others. Proteins with abundances that increased dramatically opposite the drop in phycocyanin in the control at T4 are: PSII Mn-stabilizing polypeptide (Figure 3.10), PSI reaction center 
subunit II (PsaD) (Figure 3.11), PSI reaction center subunit IV (PsaE) (Figure 3.11), PSI reaction center subunit VII (PsaC) (Figure 3.11), three subunits of ATP synthase (Figure 3.12), carboxysome shell protein and peptide (Figure 3.13), possible CcmK (Figure 3.13), ribulose 5-phosphate isomerase (Figure 3.14), among others. This suggests a change in regulation of these groups of proteins, perhaps triggered by cell death.

During the transition from stationary phase to death phase (T3-T5) in a Zndeprived culture with $44 \mathrm{pM} \mathrm{Cd}^{2+}$ added, similar to the control, there was a decrease of phycocyanin (Figure 3.9) and PSII proteins (Figure 3.10) with a concurrent increase in PSI (Figure 3.11) and carboxysome-associated proteins (Figure 3.13). Unlike the control, the abundance of ATP synthase remained low throughout the time course for this treatment (Figure 3.12). Many, but not all of the same proteins change in similar ways to the control from T3 to T4. The protein abundances that drop dramatically with the phycocyanin in $\mathrm{Cd}$ and the control are: allophycocyanin (Figure 3.9), ferredoxin-NADP reductase (Figure 3.12), malate oxidoreductase (Figure 3.14), aspartate aminotransferase (Figure 3.14), transketolase (Figure 3.14), arylsulfatase (Figure 3.15), and cysteine synthase A (Figure 3.16). The protein abundances that drop dramatically with the phycocyanin in $44 \mathrm{pM} \mathrm{Cd}^{2+}$ and not in the control are: ribulose phosphate 3-epimerase (Figure 3.14), ribulose 1,5 bisphosphate carboxylase (Figure 3.13), triose phosphate isomerase (Figure 3.14), putative arylsulfatase (Figure 3.15), S-adenosylmethionine synthetase (Figure 3.16), 5' methylthioadenosine phosphorylase, and superoxide dismutase (Figure 3.17) among others. This suggests a similar downregulation of these proteins with cell death, but additional downregulation with $\mathrm{Cd}$.

The protein abundances that increase dramatically opposite the drop in pigmentation are also found to have the same pattern in the control: photosystem II Mnstabilizing polypeptide (Figure 3.10), chloroplast membrane-associated 30kD protein-like (Figure 3.10), PSI reaction center subunit II (Figure 3.11), PSI reaction center subunit IV (psaE) (Figure 3.11), PSI reaction center subunit VII (PsaC) (Figure 3.11), carboxysome shell protein (Figure 3.13), carboxysome shell peptide (Figure 3.13), possible CcmK (Figure 3.13), among others. This supports the idea of a similar upregulation in these 
proteins with cell death. In summary, during stationary phase in a Zn-deprived culture with $44 \mathrm{pM} \mathrm{Cd}^{2+}$ added, there is a decrease of PSII pigmentation with a concurrent increase in PSI and carboxysome-associated proteins, but the abundance of ATP synthase remains low throughout the time course for this treatment. This suggests that similar to the control, ribulose 1,5 bisphosphate carboxylase levels are low, the PSI/PSII ratio increases with a concurrent increase in attempted carboxysome-associated carbon fixation, but contrary to the control, the ATP production could be limited because of the lower abundance of ATP synthase. Direct measurements of ATP were not made, but limited ATP production by the light driven electron flow could cause a cascade of negative effects, including decrease in active transport of $\mathrm{HCO}_{3}{ }^{-}$into the cell cytosol, which could provoke an increase in quantity of carboxysomes in order to produce the same amount of carbon dioxide for ribulose 1,5 bisphosphate carboxylase to fix (Figure 3.13). If carbonic anhydrase were detectable, one might also expect this relative abundance of this enzyme to increase. A decrease in ATP production may decrease the active transport of nitrate and phosphate. This could link $\mathrm{Cd}$ to the nutrient phosphate, but also nitrate and carbon. Ribulose 1,5 bisphosphate carboxylase did not appear to respond to the dramatic decrease in phycocyanin observed in the control at T4; it had steadily decreased in relative abundance since T2. Ribulose 1,5 bisphosphate carboxylase was also decreased in abundance in the $44 \mathrm{pM} \mathrm{Cd}^{2+}$ treatment from $\mathrm{T} 3$ to $\mathrm{T} 5$, however, similar to the control this decrease did not appear to be related to the decline in phycocyanin.

\section{Carbon fixation - carboxysome associated}

The products of the light reactions of photosynthesis and $\mathrm{CO}_{2}$ are used in carbon fixation. Cyanobacteria can concentrate $\mathrm{CO}_{2}$ using a carbon concentrating mechanism involving the cell membrane and conversion to $\mathrm{HCO}_{3}{ }^{-}$. The $\mathrm{HCO}_{3}{ }^{-}$is taken into the carboxysome where carbonic anhydrase converts it back to $\mathrm{CO}_{2}$. Carboxysomes are polyhedral crystalline structures found in cyanobacteria. In literature older then fifty years, they used to be referred to as polyhedral bodies, but in the 70's they were discovered to be structures related to photosynthesis (Yeates et al., 2008). Structural 
studies of the carboxysome shell itself suggest that it controls metabolite flow into and out of the carboxysome (Kerfeld, 2005). The high density of ribulose 1,5 bisphosphate carboxylase concentrated in the carboxysome combines a molecule of $\mathrm{CO}_{2}$ with a molecule of ribulose 1,5 bisphosphate and water to form two molecules of glycerate-3phosphate, or PGA. Ribulose 1,5 bisphosphate carboxylase is the most abundant protein in the world (Ellis, 1979) and accounts for $70 \%$ of the carboxysome by weight, with the main shell proteins accounting for $17 \%$ of the carboxysome (Yeats et al., 2008).

Although we did not detect a carbonic anhydrase, we observed four carboxysomeassociated proteins more than two-fold differentially abundant between the control and at least one of the $\mathrm{Cd}$ treatments at one of the timepoints: a possible carbon concentrating mechanism protein, the carboxysome shell protein, the carboxysome shell peptide and the small subunit of ribulose 1,5 bisphosphate carboxylase (Figure 3.13). As with PSI proteins, some of the most dramatic differences in relative protein abundance between the treatments are observed in these carboxysome-associated proteins.

The possible carbon concentrating mechanism protein $(\mathrm{CcmK})$, carboxysome shell peptide and carboxysome shell protein showed similar relative abundances distributions with one difference (Figure 3.13). These proteins were more abundant in the control and $4.4 \mathrm{pM} \mathrm{Cd}^{2+}$ than the $44 \mathrm{pM} \mathrm{Cd}^{2+}$ treatment during exponential growth (T1) (Figure 3.13, Table 3.2). They were more abundant in the control than both of the Cd treatments during late stationary (T4) (Figure 3.13, Table II.6). During very late stationary/death (T5), however, the possible CcmK and carboxysome shell peptide proteins were more abundant in the $44 \mathrm{pM} \mathrm{Cd}^{2+}$ than either the control or $4.4 \mathrm{pM} \mathrm{Cd}^{2+}$, whereas the carboxysome shell protein was more abundant in both of the Cd treatments relative to the control (Figure 3.13, Table 3.3).

The small subunit of ribulose 1,5 bisphosphate carboxylase (rubisco), the enzyme with a $\mathrm{Mg}^{2+}$ cofactor that catalyzes the first step of the Calvin cycle, was more abundant in both of the $\mathrm{Cd}$ treatments relative to the control during mid-stationary (T3) (Figure 3.13, Table II.3). It was more abundant during growth, early and mid-stationary (T1, T2, T3) than late stationary and very late stationary/death (T4, T5) (Figure 3.13). 

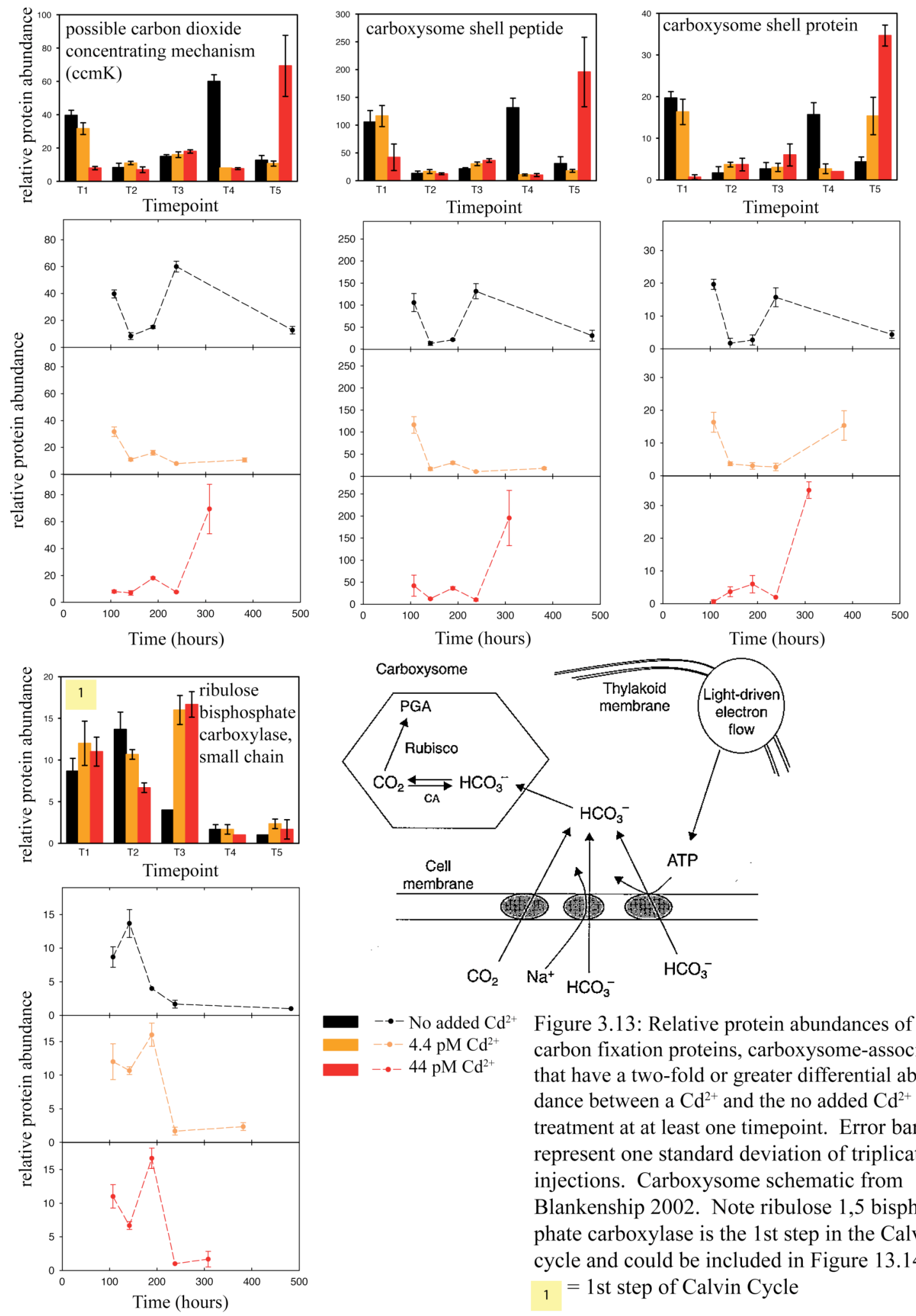

- - No added $\mathrm{Cd}^{2+}$

$-4.4 \mathrm{pM} \mathrm{Cd}^{2+}$

Figure 3.13: Relative protein abundances of carbon fixation proteins, carboxysome-associated, that have a two-fold or greater differential abundance between a $\mathrm{Cd}^{2+}$ and the no added $\mathrm{Cd}^{2+}$ treatment at at least one timepoint. Error bars represent one standard deviation of triplicate injections. Carboxysome schematic from Blankenship 2002. Note ribulose 1,5 bisphosphate carboxylase is the 1st step in the Calvin cycle and could be included in Figure 13.14. $1=1$ st step of Calvin Cycle 
As with PSI proteins, some of the most dramatic differences in relative protein abundance between the treatments are observed in these carboxysome-associated proteins (Figure 3.13, Tables 3.2, II.2, II.3, II.6, 3.3). We see other parts of the carboxysome, the shell protein, the shell peptides, and the small subunit of rubisco. We do not detect the large subunit of rubisco, or carbonic anhydrase.

The small subunit of ribulose 1,5 bisphosphate carboxylase was highly abundant during mid-stationary phase (T3) in both of the Cd treatments, whereas it had already begun to drop in the control treatments. A higher abundance of this protein could indicate more function, or more presence with lack of function.

The greater abundance of the small subunit of rubisco during exponential growth, early, and mid-stationary $(\mathrm{T} 1, \mathrm{~T} 2, \mathrm{~T} 3)$ than late stationary and very late stationary/death (T4, T5) (Figure 3.13) suggests that the conversion of carbon dioxide to PGA is more active during exponential growth phase. At T3, when rubisco and arylsulfatase relative abundances spike and the chlorophyll/phycoerythrin ratios start to change for the $\mathrm{Cd}$ treatments, rubisco is decreasing in the control treatment.

The similar distribution of the possible carbon concentrating mechanism (CcmK), carboxysome shell peptide, and carboxysome shell protein indicates that these three proteins could be transcriptionally related.

Because the only known nutritive use of $\mathrm{Cd}$ so far has been in a carbonic anhydrase in the diatom $T$. weissflogii, the detection of carbonic anhydrases is desirable (see future directions). Synechococcus WH5701 has an annotated carbonic anhydrase, a possible carbonic anhydrase, a carbonic anhydrase-like protein, and carboxysome shell polypeptide, the latter with high similarities to $\beta$-carbonic anhydrases.

\section{Carbon fixation - Calvin cycle proteins}

The products of the light reactions of photosynthesis, along with $\mathrm{CO}_{2}$ are used in carbon fixation, the Calvin cycle. Six proteins involved in the Calvin cycle, a 12 step enzymatic process, were more than two-fold differentially abundant between the control and at least one of the $\mathrm{Cd}$ treatments during one of the growth phases (Figure 13.14). These 6 proteins are the aforementioned small subunit of rubisco (Step 1), 
phosphoglycerate kinase (Step 2), glyceraldehyde-3-phosphate dehydrogenase (NADP ${ }^{+}$; phosphorylating) (Step 3), triosephosphate isomerase (Step 4), transketolase (Steps 7 and 10), ribose 5-phosphate isomerase (Step 12) (Figure 13.14). Three other proteins involved in carbon fixation were also differentially abundant. These proteins are malate oxidoreductase, aspartate aminotransferase, and ribulose-phosphate-3-epimerase.

Phosphoglycerate kinase, step 2 of the Calvin cycle, catalyzes the reaction of glycerate-3-phosphate (PGA), and ATP to 1,3 bisphosphoglycerate (BPG) and ADP. It was more abundant in the control than both of the $\mathrm{Cd}$ treatments during early stationary and very late stationary/death (T2 and T5) (Figure 13.14, Tables II.2, 3.4).

Glyceraldehyde-3-phosphate dehydrogenase (NADP ${ }^{+}$; phosphorylating), step 3 of the Calvin cycle, catalyzes the reaction of BPG and NADPH to glyceraldehyde-3phosphate (GAP) and $\mathrm{NADP}^{+}$. It was more abundant in the $44 \mathrm{pM} \mathrm{Cd}^{2+}$ than the control and $4.4 \mathrm{pM} \mathrm{Cd}^{2+}$ treatments during exponential growth (T1) (Figure 13.14, Table 3.1). It was more abundant in the control than both of the Cd treatments during mid-stationary (T3) (Figure 13.14, Table II.4). During very late stationary/death (T5), it was more abundant in the control than the $4.4 \mathrm{pM} \mathrm{Cd}^{2+}$ treatment (Figure 13.14, Table 3.4).

Triosephosphate isomerase, step 4 of the Calvin cycle catalyzes the reaction of GAP to dihydroxyacetone phosphate (DHAP). It is more abundant in the control than the $44 \mathrm{pM} \mathrm{Cd}^{2+}$ treatment during late stationary/death (T5) (Figure 13.14, Table 3.4).

Transketolase, steps 7 and 10 of the Calvin cycle, catalyzes the reaction of fructose 6-phosphate (F6P) and GAP to erythrose 4-phosphate (E4P) and xyulose 5phosphate (X5P) in step 7 and the reaction of sedoheptulose 7-bisphosphate (S7P) and GAP to ribose 5-phosphate (R5P) and X5P in step 10. Transketolase is more abundant in the $44 \mathrm{pM} \mathrm{Cd}^{2+}$ treatment than the control during exponential growth (T1) (Figure 13.14, Table 3.1). It is more abundant in both $\mathrm{Cd}$ treatments than the control during late stationary (T4) (Figure 13.14, Table II.5). It is more abundant in the control than both $\mathrm{Cd}$ treatments during very late stationary/death (T5) (Figure 13.14, Table 3.4).

Ribose 5-phosphate isomerase, step 12 of the Calvin cycle, catalyzes the reaction of $\mathrm{R} 5 \mathrm{P}$ to ribulose 5-phosphate (Ru5P). It is more abundant in the control than both $\mathrm{Cd}$ 
treatments during late stationary (T4) (Figure 13.14, Table II.6). It is more abundant in the control and the $4.4 \mathrm{pM} \mathrm{Cd}^{2+}$ treatment than the $44 \mathrm{pM} \mathrm{Cd}^{2+}$ treatment during very late stationary/death (T5) (Figure 13.14, Table 3.4).

Malate oxidoreductase is more abundant in the $44 \mathrm{pM} \mathrm{Cd}^{2+}$ treatment than the control and the $4.4 \mathrm{pM} \mathrm{Cd}^{2+}$ treatment during growth (T1) (Figure 13.14, Table 3.1). It is more abundant in both $\mathrm{Cd}$ treatments than the control during late stationary (T4) (Figure 13.14, Table II.5). During very late stationary/death (T5), however, it is more abundant in the control than both $\mathrm{Cd}$ treatments (Figure 13.14 and Table 3.4).

As well as being involved in carbon fixation, aspartate aminotransferase is also involved in amino acid metabolism, including cysteine. Like malate oxidoreductase, it is more abundant in the $44 \mathrm{pM} \mathrm{Cd}^{2+}$ treatment than the control and the $4.4 \mathrm{pM} \mathrm{Cd}^{2+}$ treatment during exponential growth (T1) (Figure 13.14, Table 3.1) and is more abundant in both Cd treatments than the control during late stationary (T4) (Figure 13.14, Table II.5). During very late stationary/death (T5), however, unlike malate oxidoreductase, it is more abundant in both the control and the $4.4 \mathrm{pM} \mathrm{Cd}^{2+}$ treatment than the $44 \mathrm{pM}$ $\mathrm{Cd}^{2+}$ treatment (Figure 13.14, Table 3.4).

Ribulose-phosphate-3-epimerase catalyzes the reaction of R5P into X5P. It is more abundant in the control than the $4.4 \mathrm{pM} \mathrm{Cd}^{2+}$ treatment during exponential growth phase (T1) (Figure 13.14, Table 3.2). It is more abundant in the control than the $44 \mathrm{pM}$ $\mathrm{Cd}^{2+}$ during very late stationary/death (T5) (Figure 13.14, Table 3.4). 

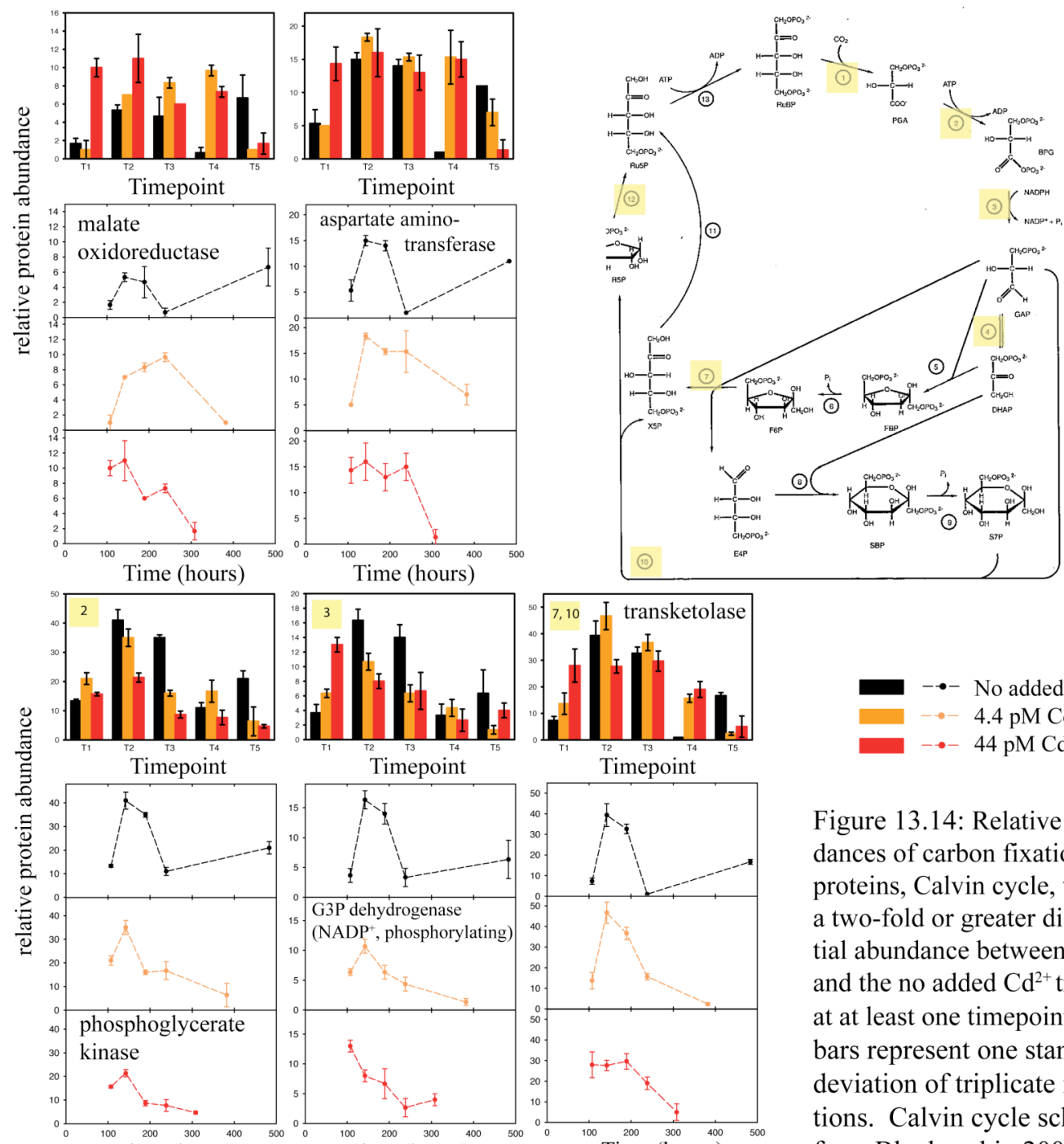

Time (hours)
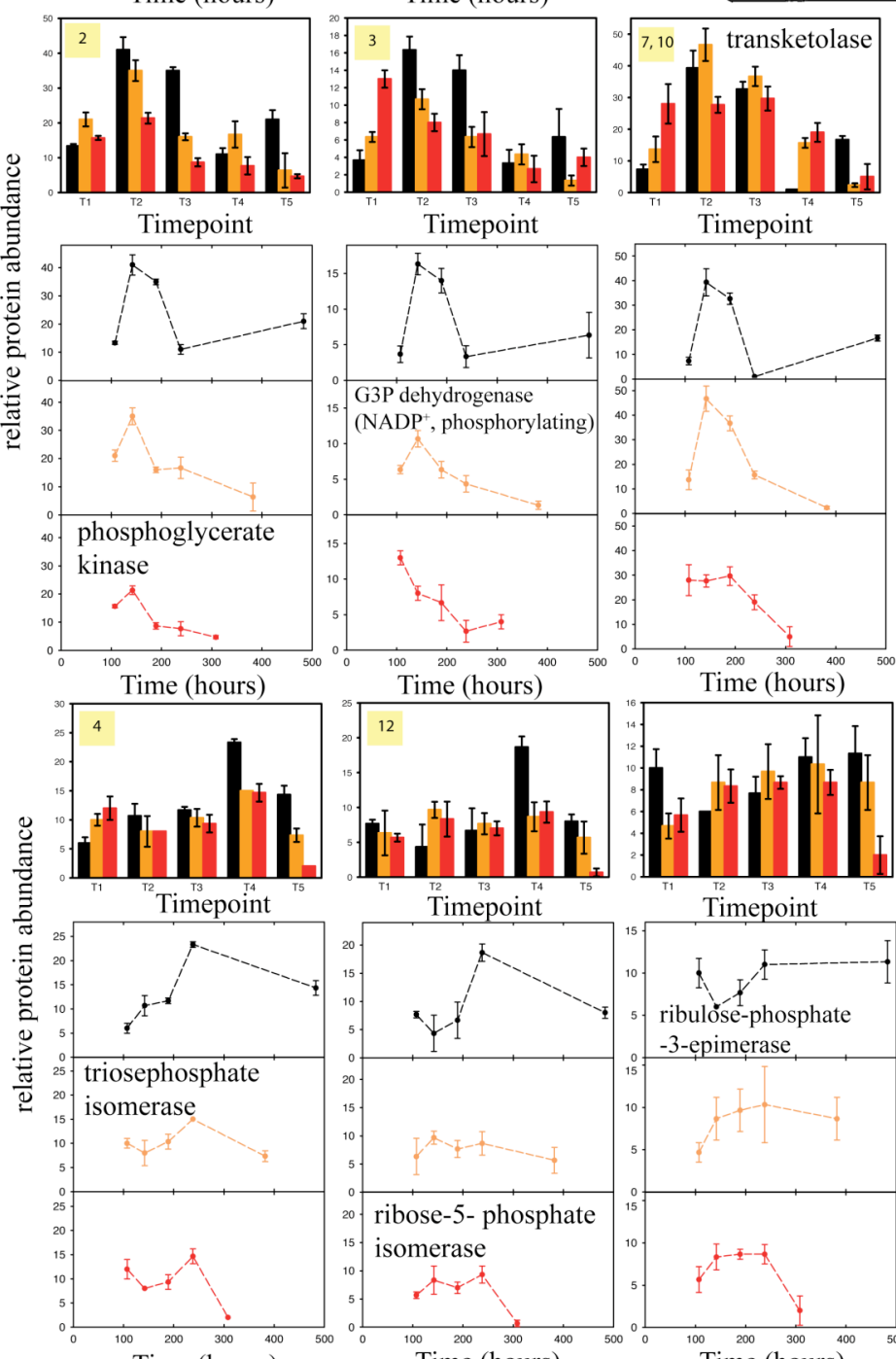

Time (hours)

Time (hours)
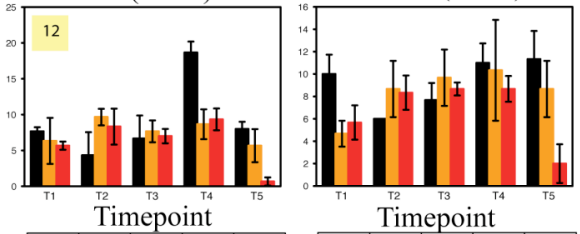

Timepoint
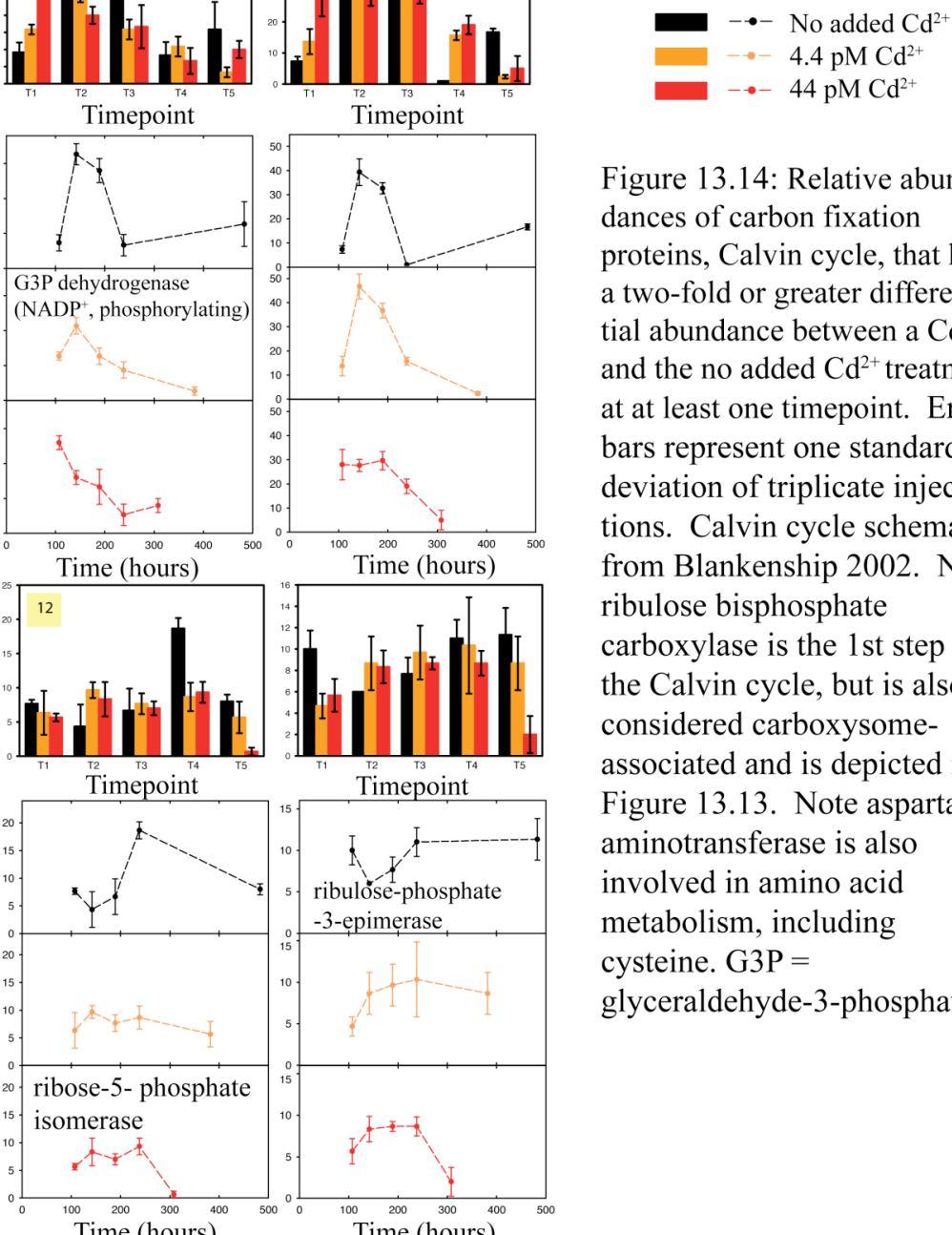

Figure 13.14: Relative abundances of carbon fixation proteins, Calvin cycle, that have a two-fold or greater differential abundance between a $\mathrm{Cd}^{2+}$ and the no added $\mathrm{Cd}^{2+}$ treatment at at least one timepoint. Error bars represent one standard deviation of triplicate injections. Calvin cycle schematic from Blankenship 2002. Note ribulose bisphosphate carboxylase is the 1st step in the Calvin cycle, but is also considered carboxysomeassociated and is depicted in Figure 13.13. Note aspartate aminotransferase is also involved in amino acid metabolism, including cysteine. G3P = glyceraldehyde-3-phosphate. 
Many of these proteins have relative abundance distributions opposite that of the carboxysome-associated proteins (Figures $3.13,3.14$ ). The Calvin cycle is affected by Cd: 6 of the 12 enzymes involved in the Calvin cycle and three other proteins were more than two-fold differentially abundant between the control and at least one of the $\mathrm{Cd}$ treatments at one of the time points (Figure 3.14).

Five proteins show a similar distribution pattern with 3 of the 6 Calvin cycle enzymes along with two of the other proteins; they are phosphoglycerate kinase (Step 2), glyceraldehyde-3-phosphate dehydrogenase (NADP ${ }^{+}$; phosphorylating) (Step 3), transketolase (Steps 7 and 10), malate oxidoreductase, and aspartate aminotransferase (Figure 3.14). Three more proteins have similar distributions to one another: triosephosphate isomerase (Step 4), ribose 5-phosphate isomerase and ribulose phosphate 3-epimerase (Figure 3.14). Rubisco has a unique distribution among the 9 proteins, most resembling the 5 proteins with a similar distribution pattern (Figure 3.13). Overall, many of the Calvin cycle enzymes are affected in a similar way, suggesting similar regulation.

\section{Arylsulfatases}

Two proteins involved in steroid and lipid biosynthesis, an arylsulfatase and a putative arylsulfatase, showed dramatic differential abundances throughout this experiment. These arylsulfatases were more than two-fold differentially abundant between the control and at least one of the $\mathrm{Cd}$ treatments at three of the timepoints (Figure 3.15). At least one of these proteins was differentially abundant at every timepoint.

The arylsulfatase was more abundant in both $\mathrm{Cd}$ treatments than the control during exponential growth (T1) (Figure 3.15, Table 3.1). It was more abundant in the control and $4.4 \mathrm{pM} \mathrm{Cd}^{2+}$ treatment than the $44 \mathrm{pM} \mathrm{Cd}^{2+}$ treatment during early stationary (T2) (Figure 3.15, Table II.2). During very late stationary/death (T5), however, it was more abundant in the control than the Cd treatments (Figure 3.15, Table 3.4).

The putative arylsulfatase showed a distribution similar to the arylsulfatase in that it was more abundant in both $\mathrm{Cd}$ treatments than the control during exponential growth (T1), although unlike the arylsulfatase it was also twice as abundant in the $44 \mathrm{pM} \mathrm{Cd}^{2+}$ as 
the $4.4 \mathrm{pM} \mathrm{Cd}^{2+}$ (Figure 3.15, Table 3.1). Unlike the arylsulfatase, the putative arylsulfatase was more abundant in both $\mathrm{Cd}$ treatments than the control during midstationary (T3) (Figure 3.15, Table II.3). Like the arylsulfatase, as the experiment progressed through the last two stationary phases, the protein was more abundant in the control compared to the two Cd treatments. For the putative arylsulfatase, this occurred in late stationary (T4) (Figure 3.15, Table II.6), compared to the arylsulfatase in which the greater abundance in the control than the $\mathrm{Cd}$ treatment occurred in very late stationary/death (T5).

Combining the relative abundances of the arylsulfatases, the same overall trends remain with greater abundance in the $\mathrm{Cd}$ treatments than the control during exponential growth (T1) (Figure 3.15 and Table 3.1), in the control and $4.4 \mathrm{pM} \mathrm{Cd}^{2+}$ treatment than the $44 \mathrm{pM} \mathrm{Cd}^{2+}$ treatment during early stationary (T2) (Figure 3.15 and Table II.2), in both Cd treatments than the control during mid-stationary (T3) (Figure 3.15 and Table II.3) and in the control than both Cd treatments during very late stationary/death (T5) (Figure 3.15 and Table 3.4).

Sulfur metabolism is linked with lipid and steroid biosynthesis. The involvement of arylsulfatases in steroid and lipid biosynthesis is directly related to sulfur metabolism. Arylsulfatases remove sulfate groups from carbohydrates and other compounds. In Chlamydomonas reinhardtii the presence of arylsulfatases implies sulfur starvation (Zhang et al., 2004). We see an over abundance of arylsulfatases in the Cd treatments relative to the control during exponential growth (T1). This could imply that the Cd treatments are procuring sulfur from sulfate esters. The extra sulfur could be used to synthesize cysteine, which can be used to make glutathione, other small thiols and possibly metallothionein, all of which could bind Cd. Sulfate, cysteine, and other components of the cysteine biosynthesis pathway have been shown to repress arylsulfatase formation in different ways in different bacteria, suggesting regulation of this enzyme (Fitzgerald, 1976 and references therein). This supports the hypothesis that $\mathrm{Cd}$ is being bound by cysteine or other thiols comprised of cysteine, causing a shortage, activating the formation of arylsulfatases to produce more cysteine. In a different study, 
the arylsulfatase from Helix pomatia, a snail, was activated by $\mathrm{Cd}^{2+}$ in solution; the authors suggested the recovery of sulfate for the ensuing processing of $\mathrm{Cd}$ (Tokheim et al., 2005).
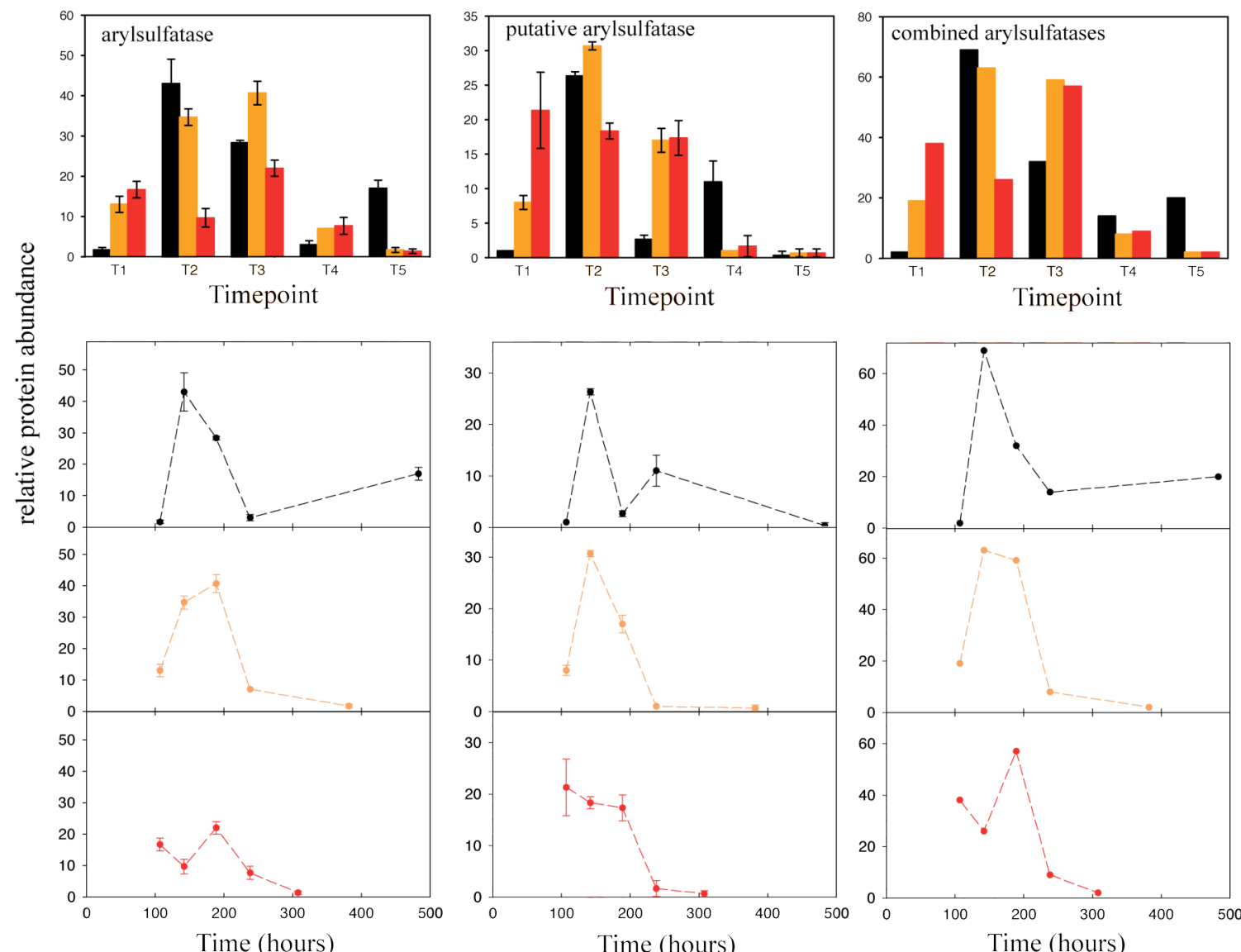

Timepoint

Timepoint
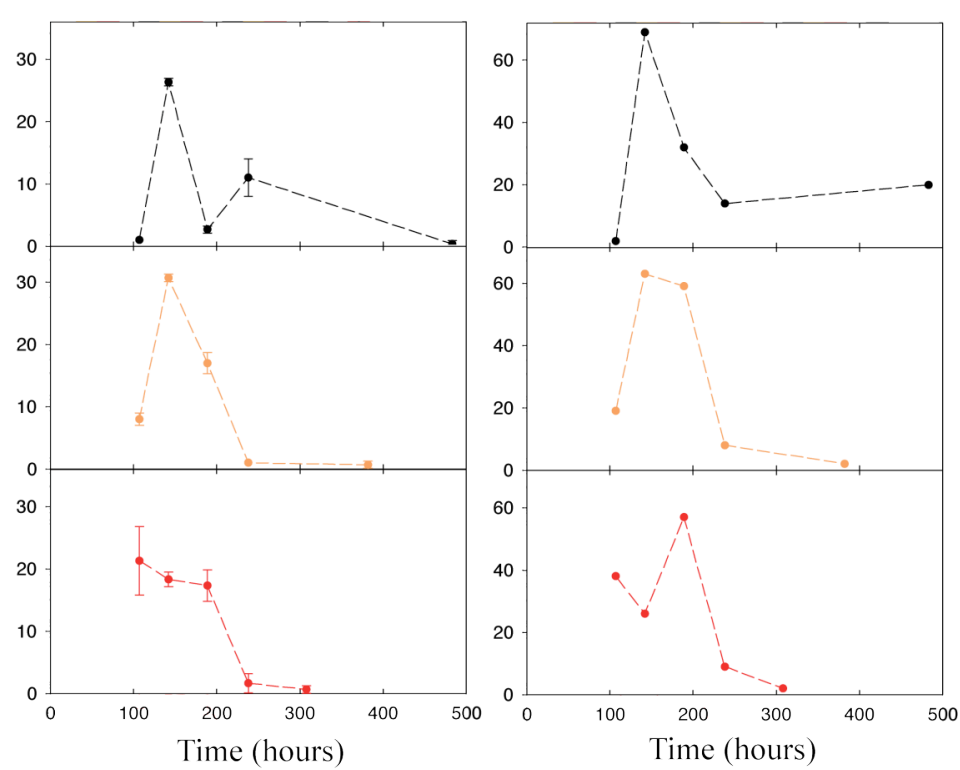

-- No added $\mathrm{Cd}^{2}$
$--4.4 \mathrm{pM} \mathrm{Cd}^{2+}$
$--44 \mathrm{pM} \mathrm{Cd}^{2+}$

Figure 3.15: Relative abundances of steroid and lipid biosynthesis proteins. Error bars represent one standard deviation of triplicate injections. Note that the combined arylsulfatases have a protein abundance distribuion similar to that of ribulose 1,5 bisphosphate carboxylase, small chain, Figure 3.13.

In humans, arylsulfatases are found in lysosomes in the brain. A deficiency of arylsulfatases causes lysosomal storage disease, a disorder that affects the myelin sheath around nerve cells and results in the accumulation of sulfatide, which in turn affects trafficking homeostasis. The presence of sulfatases is the earliest sign of Alzheimers disease, metachromatic leukodystrophy. In cyanobacteria, we noticed a higher mortality rate in treatments with added $\mathrm{Cd}$, and the differences in arylsulfatases relative abundances were among the most notable. The $\mathrm{Cd}$ treatments have more arylsulfatases in exponential growth phase and the control had a high abundance of them during stationary 
phase, perhaps indicating sulfur starvation or some stationary phase process. The presence of arylsulfatases observed in this experiment could be a sign of cellular death and destruction in cyanobacteria (see future directions). The increased exposure to $\mathrm{Cd}$ could result in the induction of apoptosis by an as yet unknown mechanism. This mechanism could be related to $\mathrm{Zn}$, the observed disturbance in carbon metabolism, the observed disturbance in sulfur metabolism, or perhaps an interference with calcium $(\mathrm{Ca})$. $\mathrm{Cd}$ and $\mathrm{Ca}$ have similar atomic radii $\left(\mathrm{Ca}^{2+}-1.06 \mathrm{~A}\right.$ compared to $\mathrm{Cd}^{2+}-1.03 \mathrm{~A}$, Goldschmidt, 1964). In mammalian cells, calcium is associated with apoptosis, but these pathways are poorly understood and undocumented in cyanobacteria.

The arylsulfatase and putative arylsulfatase showed dramatic differential protein abundances throughout this experiment. These arylsulfatases were more than two-fold differentially abundant between the control and at least one of the $\mathrm{Cd}$ treatments at three of the time points (Figure 3.15). At least one of these proteins was differentially abundant at every time point.

Judging by the combined arylsulfatase relative protein abundance distributions in the control, arylsulfatases are not abundant during growth, become abundant upon the transition to stationary phase, and decrease to a steady level of moderate abundance (Figure 3.15). Abundances in the $\mathrm{Cd}$ treatments do not follow this distribution, both having greater abundances than the control during growth and low abundances during death phase (T5) (Figure 3.15, Tables 3.1, II.2, II.3, II.6, 3.4). The $4.4 \mathrm{pM} \mathrm{Cd}^{2+}$ treatment mimics the control in the drastic increase of arylsulfatase upon the transition to stationary phase, but unlike the control the $4.4 \mathrm{pM} \mathrm{Cd}^{2+}$ treatment maintains arylsulfatase abundance through mid-stationary phase (T3) before dropping to late stationary phase (T4) low abundances. The $44 \mathrm{pM} \mathrm{Cd}^{2+}$ has moderately high abundances during growth phase, unlike the control and $4.4 \mathrm{pM} \mathrm{Cd}^{2+}$ treatment and does not spike in the transition to stationary phase (T2), but does spike during mid-stationary (T3), then declines rapidly. This pattern suggests that arylsulfatases are important in the transition to stationary phase and cells require some level of arylsulfatases throughout stationary phase. The transition to stationary phases may involve changes in many aspects of cellular metabolism, 
perhaps including protein synthesis, cellular growth, rearrangement of lipids and degradation of phycobilisomes. Cd disrupts this pattern presumably by interfering in cysteine metabolism. Also, in a possible link to carbon metabolism, the combined arylsulfatase protein distributions actually look similar to that of the small subunit of 1,5 ribulose bisphosphate carboxylase.

It is interesting to note that the scavenging of phosphorus can occur in WH5701. Sulfolipids can be used instead of phospholipids under conditions of phosphate limitation (Van Mooy et al., 2006). The cultures in this experiment are phosphate replete, so one might not expect there to be sulfolipids. Sulfolipids in this experiment, then, would probably not be the substrate for arylsulfatases. The substrate for the arylsulfatases is unknown. We do observe that in the presence of $\mathrm{Cd}$, there is a faster decline in relative abundance of pigments, which contain thioether linkages. Perhaps thioether linkages are a source of organic sulfur substrate for arylsulfatases.

\section{Sulfur and cysteine metabolism}

Five proteins involved in sulfur and/or cysteine metabolism were $\geq$ two-fold differentially abundant between the control and at least one of the Cd treatments (Figure 3.16). These proteins are aspartate aminotransferase (already presented in Figure 3.14, carbon fixation - Calvin cycle and others), cysteine synthase A, S-adenosylmethionine synthetase, 5' methylthioadenosine phosphorylase and glutamate synthetase type III.

Cysteine synthase catalyzes the reaction of $\mathrm{O}^{3}$-acetyl-L-serine and hydrogen sulfide to form L-cysteine and acetate. It was more abundant in both $\mathrm{Cd}$ treatments than the control during late stationary phase (T4) (Figure 3.16, Table II.5). It was more abundant in the control than the $44 \mathrm{pM} \mathrm{Cd}^{2+}$ treatment during very late stationary/death (T5) (Figure 3.16, Table 3.4).

S-adenosylmethionine synthetase catalyzes the reaction of methionine, ATP and water to S-adenosylmethionine, phosphate and diphosphate. It was more abundant in the $44 \mathrm{pM} \mathrm{Cd}^{2+}$ treatment than the control during exponential growth (T1) (Figure 3.16, Table 3.1). During very late stationary/death (T5), however, it was more abundant in the control than the Cd treatments (Figure 3.16, Table 3.4). 
5' methylthioadenosine phosphorylase was more abundant in the $4.4 \mathrm{pM} \mathrm{Cd}^{2+}$ than the control during mid-stationary (T3) (Figure 3.16, Table II.3). It was more abundant in both of the $\mathrm{Cd}$ treatments than the control during late stationary (T4) (Figure 3.16, Table II.5). During very late stationary/death (T5), however, it was more abundant in the control than the Cd treatments (Figure 3.16 and Table 3.4).

Glutamate synthetase type III uses ATP to catalyze the reaction of $\mathrm{NH}_{3}$ and glutamate to form glutamine, hence it is also important in nitrogen metabolism. It was more abundant in the $44 \mathrm{pM} \mathrm{Cd}^{2+}$ treatment than the control during exponential growth (T1) (Figure 3.16, Table 3.1). It was more abundant in the control than the $44 \mathrm{pM} \mathrm{Cd}^{2+}$ treatment during early stationary (T2) (Figure 3.16, Table II.2). It was more abundant in the control and the $4.4 \mathrm{pM} \mathrm{Cd}^{2+}$ than the $44 \mathrm{pM} \mathrm{Cd}^{2+}$ treatment during mid-stationary (T3) (Figure 3.16, Table II.4). It was more abundant in both Cd treatments than the control and in addition was more abundant in the $4.4 \mathrm{pM} \mathrm{Cd}^{2+}$ than the $44 \mathrm{pM} \mathrm{Cd}^{2+}$ treatment during late stationary (T4) (Figure 3.16, Table II.5). During very late stationary/death (T5) it was more abundant in the control than the Cd treatments and was more abundant in the $44 \mathrm{pM} \mathrm{Cd}^{2+}$ than the $4.4 \mathrm{pM} \mathrm{Cd}^{2+}$ treatment (Figure 3.16, Table $3.4)$.

In addition to the arylsulfatase and putative arylsulfatase, 5 proteins involved in sulfur and/or cysteine metabolism were $\geq$ two-fold differentially abundant between the control and at least one of the Cd treatments during at least one of the growth phases (Figure 3.16, Tables 3.1, II.2, II.3, II.5, 3.4). These proteins are cysteine synthase A, Sadenosylmethionine synthetase, 5' methylthioadenosine phosphorylase, and glutamate synthetase type III. Cd appears to affect sulfur and cysteine metabolism. Low molecular weight thiols and metallothioneins are known to bind metals. In this experiment, metallothioneins were detected when protein tolerances were lowered, but in small amounts. Quantification using a triple quadrupole mass spectrometer would allow quantification of this protein. In a repeat experiment, particulate and dissolved total and reduced thiols were measured by HPLC by Tristan Kading. During late log/early stationary phase (judging by fluorescence data) in only the $44 \mathrm{pM} \mathrm{Cd}^{2+}$ treatment, a pool 
of circa 1 to $10 \mathrm{nM}$ particulate total glutathione is present, presumably oxidized glutathione. These data support an alteration in sulfur and cysteine metabolism in the presence of $\mathrm{Cd}^{2+}$.

Glutathione is a tri-peptide containing the amino acids glutamate, cysteine and glycine. If the $44 \mathrm{pM} \mathrm{Cd}^{2+}$ treatment produced a high amount of glutathione, it would have needed greater amount of glutamate and glycine in addition to cysteine, which would result in increased need for nitrogen. Glutamate is also the structural base for $\delta$ aminolevulinic acid, which becomes porphobilinogen. As discussed in the chlorophyll biosynthesis section (Figure 3.8) increased relative abundances of glutamate-1semialdehyde transferase and $\delta$-aminolevulinic acid dehydratase could imply that this pathway was more active in the high $\mathrm{Cd}$ treatment, which would require greater quantities of glutamate. Increased abundances of arylsulfatases as discussed (Figure 3.15) could imply a greater need for sulfur, which could be used to make cysteine. There is also a polar amino acid transport system substrate-binding protein, WH5701_11799 that is more than two-fold greater in abundance in the $\mathrm{Cd}$ treatments during exponential growth phase (T1) (Table 3.1). Glycine and cysteine are polar amino acids. Also, it is interesting to note that low levels of cysteine were measured in the media of a repeat experiment and these levels were highest in the control (Kading and Cox et al., unpublished data). Taken together with the upregulated amino acid transporter, the cells may be importing cysteine. In addition, aspartate aminotransferase, involved in the Calvin cycle and also amino acid synthesis was more abundant in the high $\mathrm{Cd}$ treatment than the control (Figure 3.14, Table 3.1). All of these data are consistent with the idea that the cells are making sulfur compounds, in this case glutathione, to perhaps ameliorate exposure to chronic $\mathrm{Cd}^{2+}$. 

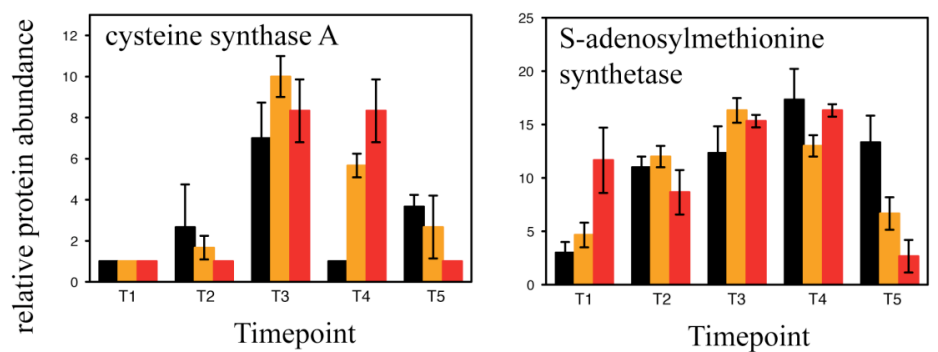

Figure 3.16: Relative abundances of proteins involved in sulfur and/or cysteine metabolism. Error bars represent one standard deviation of triplicate injections. Note aspartate aminotrans-
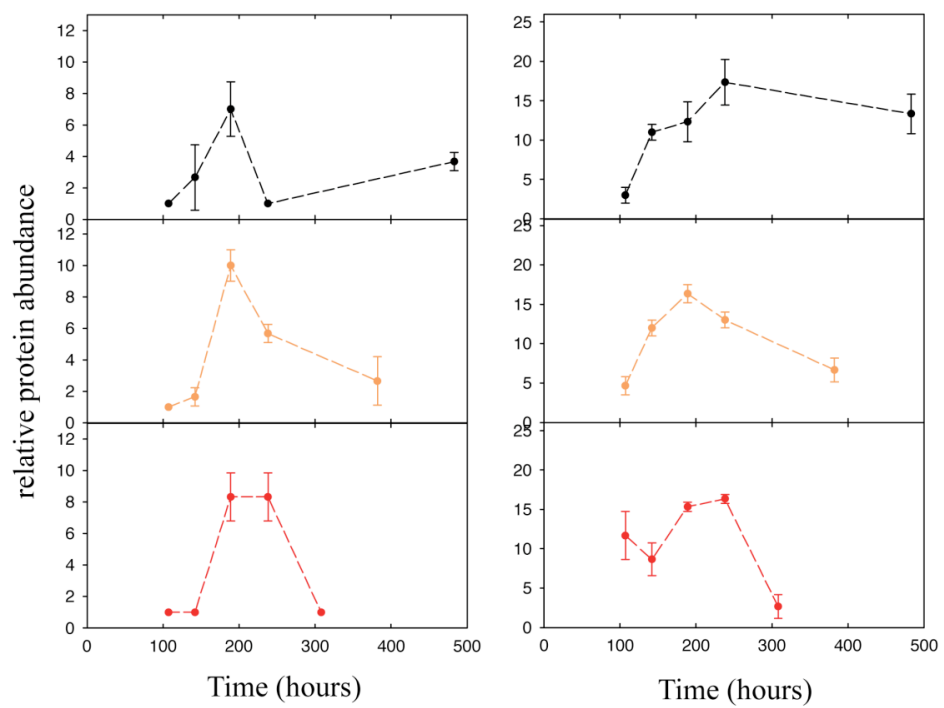
ferase in Figure 3.14 (carbon fixation, Calvin cycle) is involved in amino acid metabolism, cysteine in particular.

- - No added $\mathrm{Cd}^{2+}$ -๑4 $4.4 \mathrm{pM} \mathrm{Cd}^{2+}$ - $-44 \mathrm{pM} \mathrm{Cd}^{2+}$
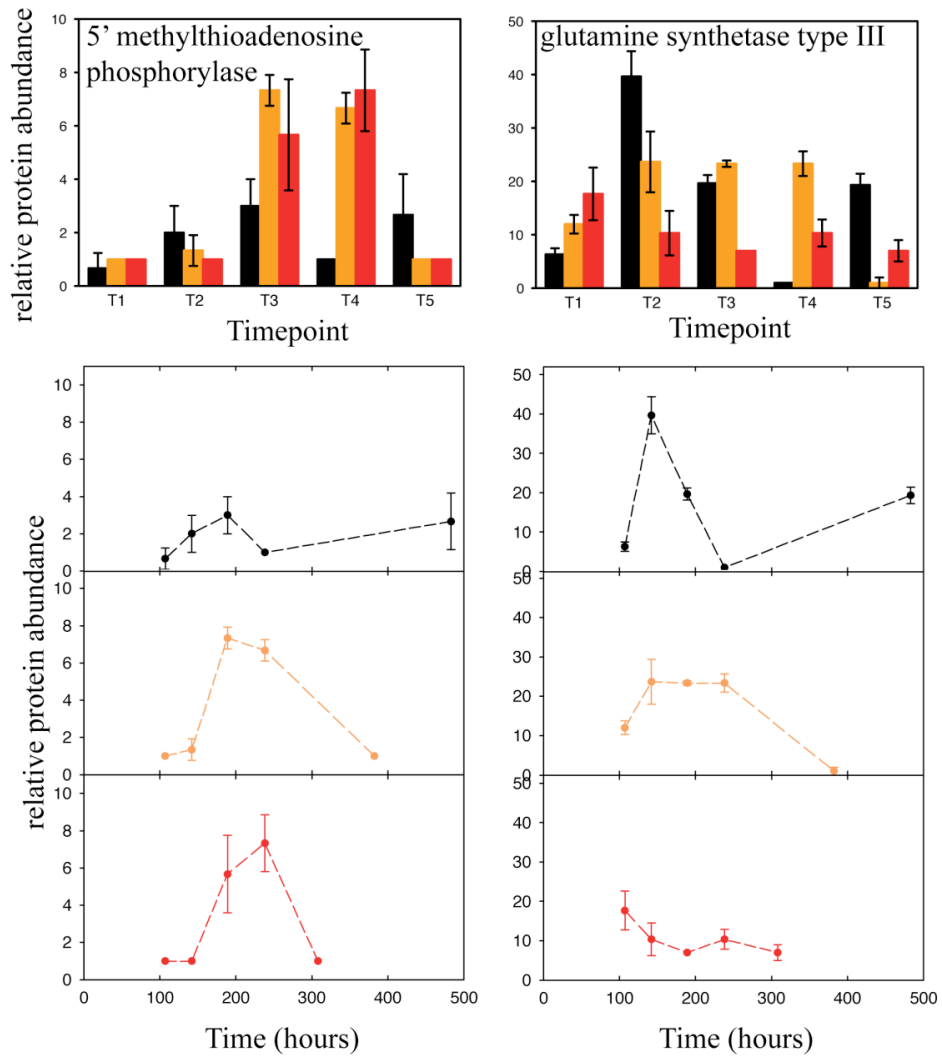


\section{Oxidative stress}

Four proteins involved in oxidative stress were $\geq$ two-fold differentially abundant between the control and at least one of the Cd treatments (Figure 3.17, Table 3.1, II.5, $3.3,3.4)$. These proteins are rehydrin, superoxide dismutase, a putative DNA protection during starvation or oxidative stress transcription regulator protein, and a fungal/archaeal/bacterial haem catalase/peroxidase. Rehydrin is more abundant in the control than the $4.4 \mathrm{pM} \mathrm{Cd}^{2+}$ during late stationary (T4) (Figure 3.17 and Table II.2). Superoxide dismutase is more abundant in the control than the $44 \mathrm{pM} \mathrm{Cd}^{2+}$ treatment during very late stationary/death (T5) (Figure 3.17 and Table 3.4). Superoxide dismutase may require $\mathrm{Cu} / \mathrm{Zn}$ in eukaryotic organisms and $\mathrm{Fe}, \mathrm{Mn}$, or $\mathrm{Ni}$ in prokaryotic organisms. The putative DNA protection during starvation or oxidative stress transcription regulator protein is more abundant in the $4.4 \mathrm{pM} \mathrm{Cd}^{2+}$ than either the control or $44 \mathrm{pM} \mathrm{Cd}^{2+}$ treatment during very late stationary/death (T5) (Figure 3.17 and Table 3.3). The fungal/archaeal/bacterial haem catalase/peroxidase is more abundant in both of the $\mathrm{Cd}$ treatments than the control during late stationary (T4) (Figure 3.17 and Table II.5). $\mathrm{Cd}^{2+}$ appears to affect the relative protein abundances of proteins involved in oxidative stress, but not in as extreme a fashion as proteins involved in carbon or sulfur metabolism. 

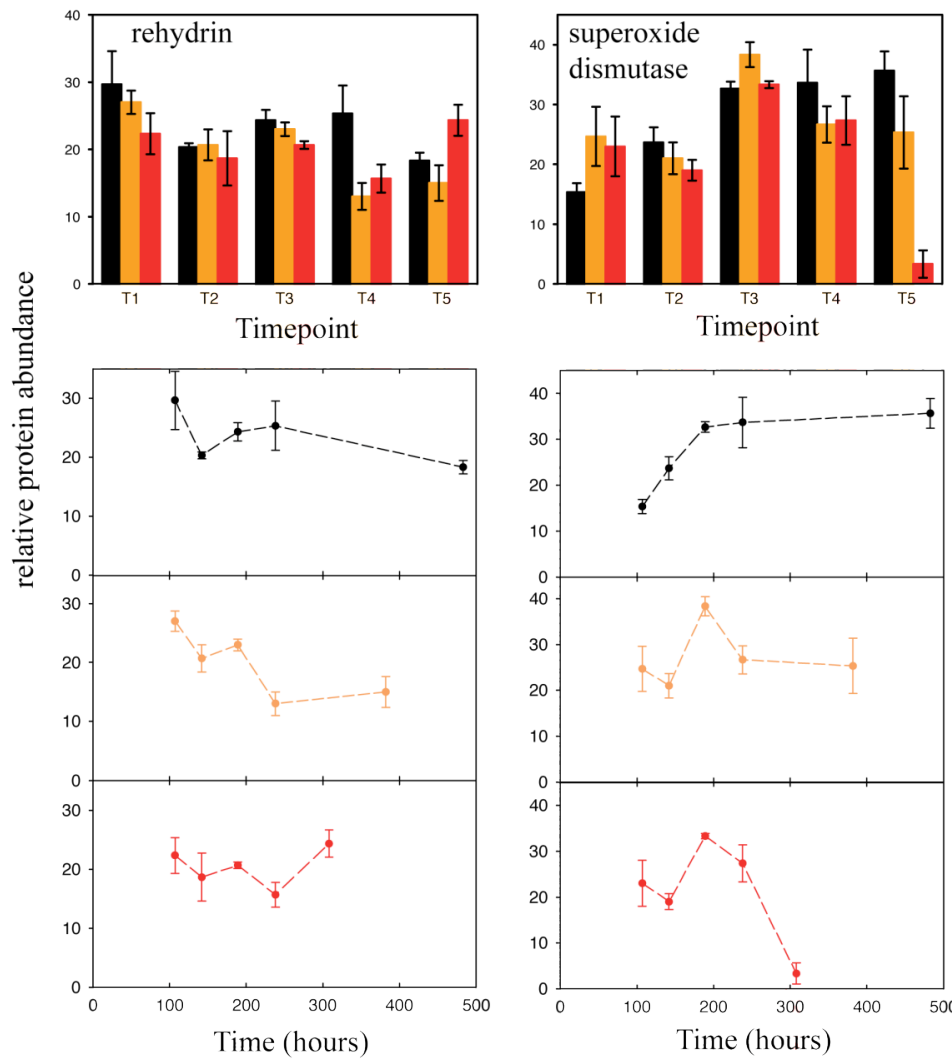

Figure 3.17: Relative abundances of oxidative stress proteins. Error bars represent one standard deviation of triplicate injections.
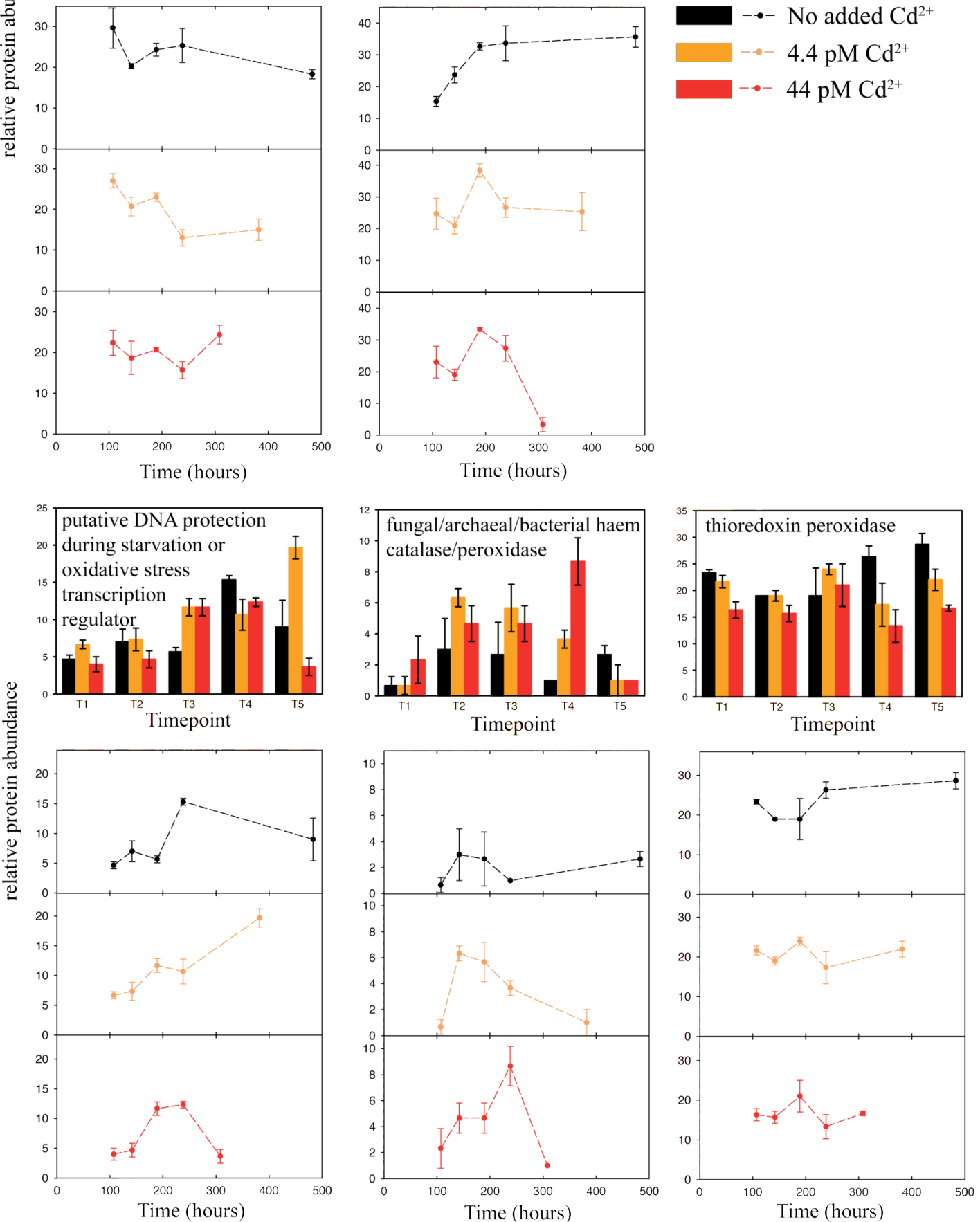


\section{Genetic information processing protein/protein synthesis}

There are many proteins involved in genetic information processing that were $\geq$ two-fold differentially abundant between the control and at least one of the $\mathrm{Cd}$ treatments (Figure 3.5, 3.18). A few of them are depicted here including 50S ribosomal protein L2, 30S ribosomal protein $\mathrm{S} 4$, polyribonucleotide nucleotidyltransferase, elongation factor EF-2, and possible protein phosphatase $2 \mathrm{C}$.

The ribosomal proteins 50S L2 and 30S S4, involved in protein synthesis, are more abundant in the Cd treatments during growth (T1) (Figure 3.18, Table 3.1). This suggests the presence of $\mathrm{Cd}^{2+}$ causes an upregulation in the synthesis of these proteins and also implies that more protein synthesis is occurring in the $\mathrm{Cd}^{2+}$ treatments than the control during growth phase. The greater abundance of ribosomal proteins in the $\mathrm{Cd}$ treatments relative to the control during $\mathrm{T} 1$ could perhaps be due to the triggering of a cell death pathway or the earlier entrance of the $\mathrm{Cd}$ treatments into a metabolic state resembling stationary phase.

The polyribonucleotide nucleotidyltransferase is more abundant in the $44 \mathrm{pM}$ $\mathrm{Cd}^{2+}$ treatment than the control during growth and mid-stationary (T1, T3) (Figure 3.18, Tables 3.1, II.3). Elongation factor EF-2 is more abundant in the $44 \mathrm{pM} \mathrm{Cd}^{2+}$ treatment than the control during growth (T1) (Figure 3.18, Table 3.1). It is more abundant in the $4.4 \mathrm{pM} \mathrm{Cd}^{2+}$ treatment than the control during late stationary (T4) (Figure 3.18, Table II.5). It is more abundant in the control than both $\mathrm{Cd}$ treatments in very late stationary/death (T5) (Figure 3.18, Table 3.4). The possible protein phosphatase $2 \mathrm{C}$ is more abundant in the control and the $4.4 \mathrm{pM} \mathrm{Cd}^{2+}$ treatment than the $44 \mathrm{pM} \mathrm{Cd}^{2+}$ treatment during growth (T1) (Figure 3.18, Table 3.2). It is more abundant in the control than both $\mathrm{Cd}$ treatments during late stationary (T4) (Figure 3.18, Table II.6). It is more abundant in the $44 \mathrm{pM} \mathrm{Cd}^{2+}$ treatment than the control and the $4.4 \mathrm{pM} \mathrm{Cd}^{2+}$ treatment during very late stationary/death (T5) (Figure 3.18, Table 3.3). 

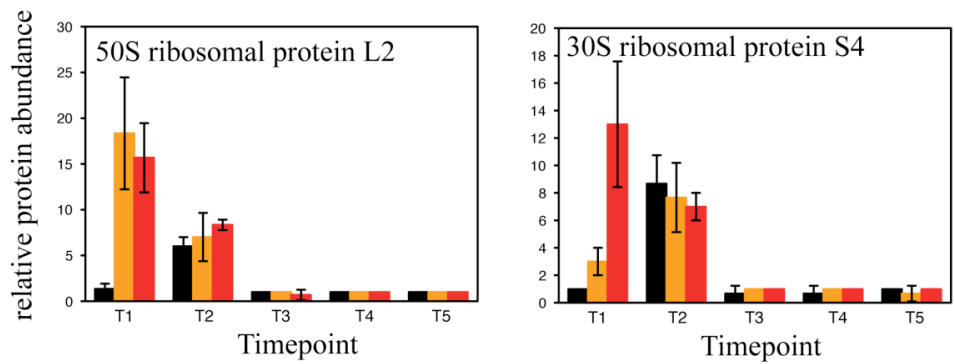

Figure 3.18: Relative abundances of genetic information processing proteins. Error bars represent one standard deviation of triplicate injections.
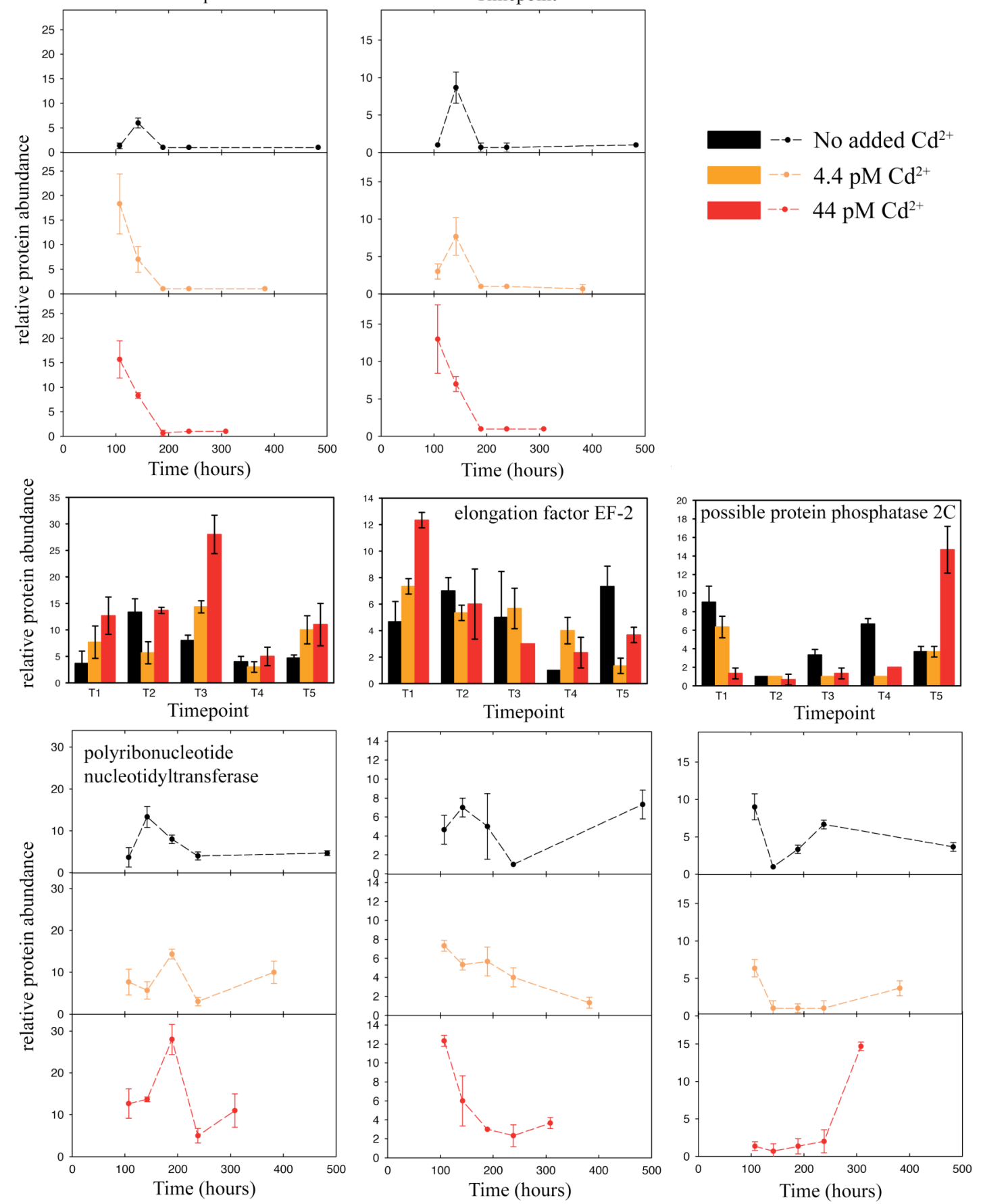


\section{Other proteins}

Many other proteins were $\geq$ two-fold differentially abundant between the control and at least one of the Cd treatments (Figures 3.19 and 3.20). A few of them are depicted here including chaperonin GroEL, co-chaperonin GroES, nuclear transport factor 2, and a extracellular binding protein (Figure 3.19). Note that GroEL is not differentially abundant, it is shown to compare to GroES. Both of these proteins are thought to help fold ribulose-1,5-bisphosphate carboxylase/oxygenase (Goloubinoff et al., 1989). The other proteins depicted are related to $\mathrm{ABC}$ transport, including a $\mathrm{ABC}$-type nitrate/nitrite transport system substrate binding protein, $\mathrm{ABC}$ transporter substrate binding protein phosphate and a putative iron $\mathrm{ABC}$ transporter substrate binding protein (Figure 3.20).

During very late stationary/death (T5) a putative iron transporter is more abundant in the control and $4.4 \mathrm{pM} \mathrm{Cd}^{2+}$ than the $44 \mathrm{pM} \mathrm{Cd}^{2+}$ treatment (Figure 3.20, Table 3.4). The fact that this protein becomes more abundant in the control and $4.4 \mathrm{pM} \mathrm{Cd}^{2+}$ as stationary phase progresses suggests that iron becomes scarce as it is utilized by the cells in these two treatments. This is similar to superoxide dismutase, which also increases steadily throughout the course of the experiment in the control, suggesting greater oxidative stress as the experiment progressed. Four possible hypotheses to explain this are: 1) The cells in $44 \mathrm{pM} \mathrm{Cd}^{2+}$ treatment are already dead or dying during $\mathrm{T} 5$ and do not need iron at that point, 2) the cells in the $44 \mathrm{pM} \mathrm{Cd}^{2+}$ treatment are more limited for something else during T5 and that limitation takes precedence over iron acquisition, 3) $\mathrm{Cd}$ is directly replacing iron somehow, and 4) $\mathrm{Cd}$ is triggering a sensor or somehow interfering with cell signaling so the mechanism indicates that the cells have an adequate iron supply. Hypothesis 1 may be less likely because the $4.4 \mathrm{pM} \mathrm{Cd}^{2+}$ treatment has a similar amount of cells, in fact less cells, and has a similar rate of degradation of phycobilisome pigmentation during death phase suggesting that the cells in the $4.4 \mathrm{pM}$ $\mathrm{Cd}^{2+}$ are also dead and dying, yet it has the putative iron transporter in a high abundance. Assuming that the presence of this transporter is indicative of iron stress or need, this would leave us with the question, why do the cells in the $44 \mathrm{pM} \mathrm{Cd}^{2+}$ not appear to need iron when cells are exposed to higher levels of $\mathrm{Cd}$, but do appear to need iron when 
exposed to low levels of $\mathrm{Cd}$. This would imply that between the 4.4 and $44 \mathrm{pM} \mathrm{Cd}^{2+}$ there is a threshold concentration over which the cells need iron. Hypothesis 2 is plausible, but again it is unlikely that cells in the $44 \mathrm{pM} \mathrm{Cd}^{2+}$ would be limited for an element that is not limiting in the $4.4 \mathrm{pM} \mathrm{Cd}^{2+}$ treatment. Hypothesis 3 is unlikely because it does not share the redox chemistry of iron, and likely would not function properly as a substitute. In addition, when WH5701 was grown on media with no added iron and no added iron plus $44 \mathrm{pM} \mathrm{Cd}^{2+}$ and monitored physiologically, these two treatments both barely grew (data not shown). This implies that $\mathrm{Cd}$ cannot nutritionally substitute for iron in this organism, as expected. This leaves us with hypothesis 4 , that $\mathrm{Cd}$ is triggering a sensor or somehow interfering with cell signaling so the mechanism indicates that the cells have an adequate iron supply.

It is also interesting to note that proteins involved in heavy metal efflux are detected, an expected response to increased exposure of heavy metals, but the spectral counts are low. The heavy metal efflux pump would need to be quantified using labeled peptides and a triple quadrupole mass spectrometer.

Co-chaperonin GroES is involved in protein folding, particularly rubisco (Golourbinoff et al., 1989). During growth phase, there are similar amounts of protein among all of the treatments (Figure 3.19). During death phase, $44 \mathrm{pM} \mathrm{Cd}^{2+}$ has approximately five times more than either $4.4 \mathrm{pM} \mathrm{Cd}^{2+}$ or the control. This is just like many of the carboxysome-associated proteins (Figure 3.13), suggesting similar regulation. 

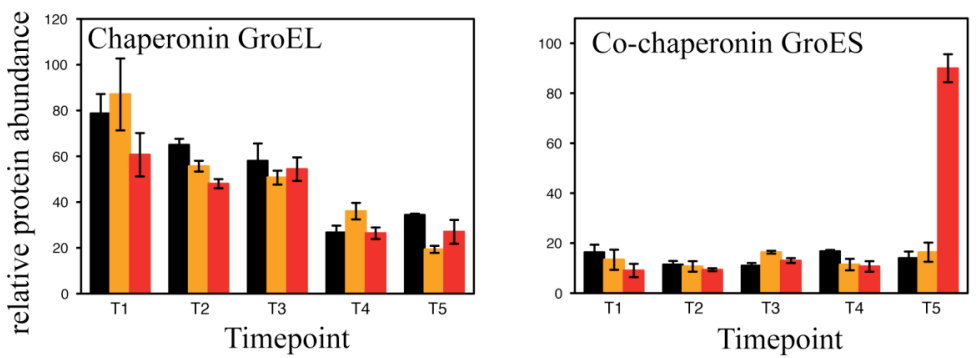

Figure 3.19: Relative abundances of other notable proteins. Error bars represent one standard deviation of triplicate injections. GroEL and GroES are involved in protein folding, espe-
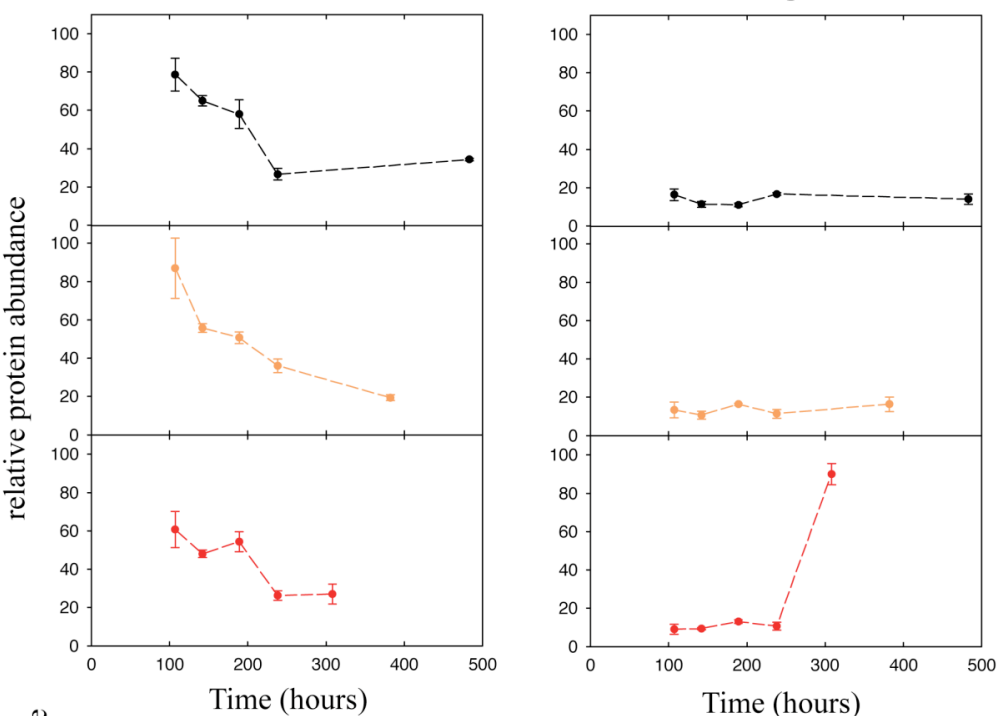
cially rubisco.
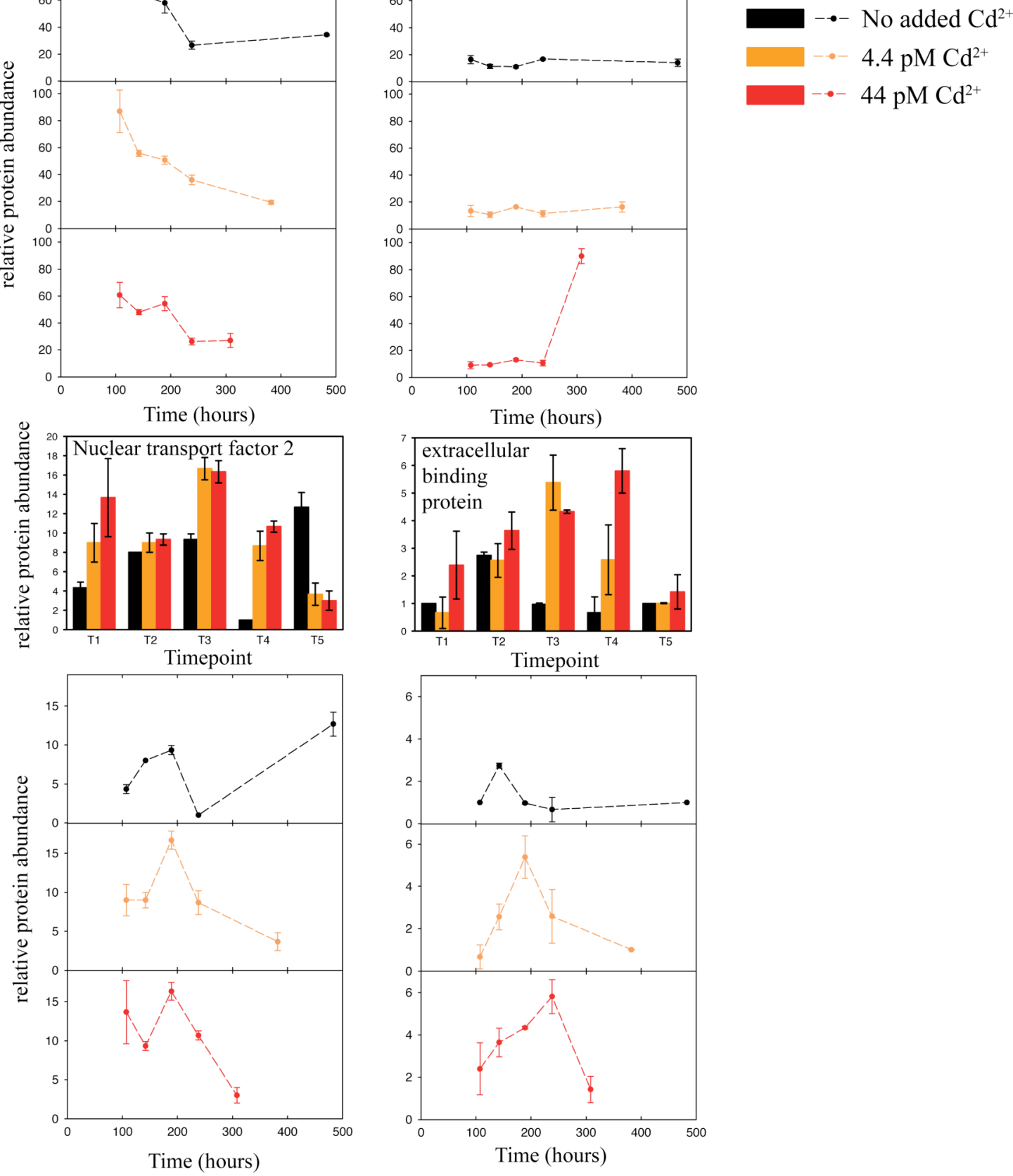

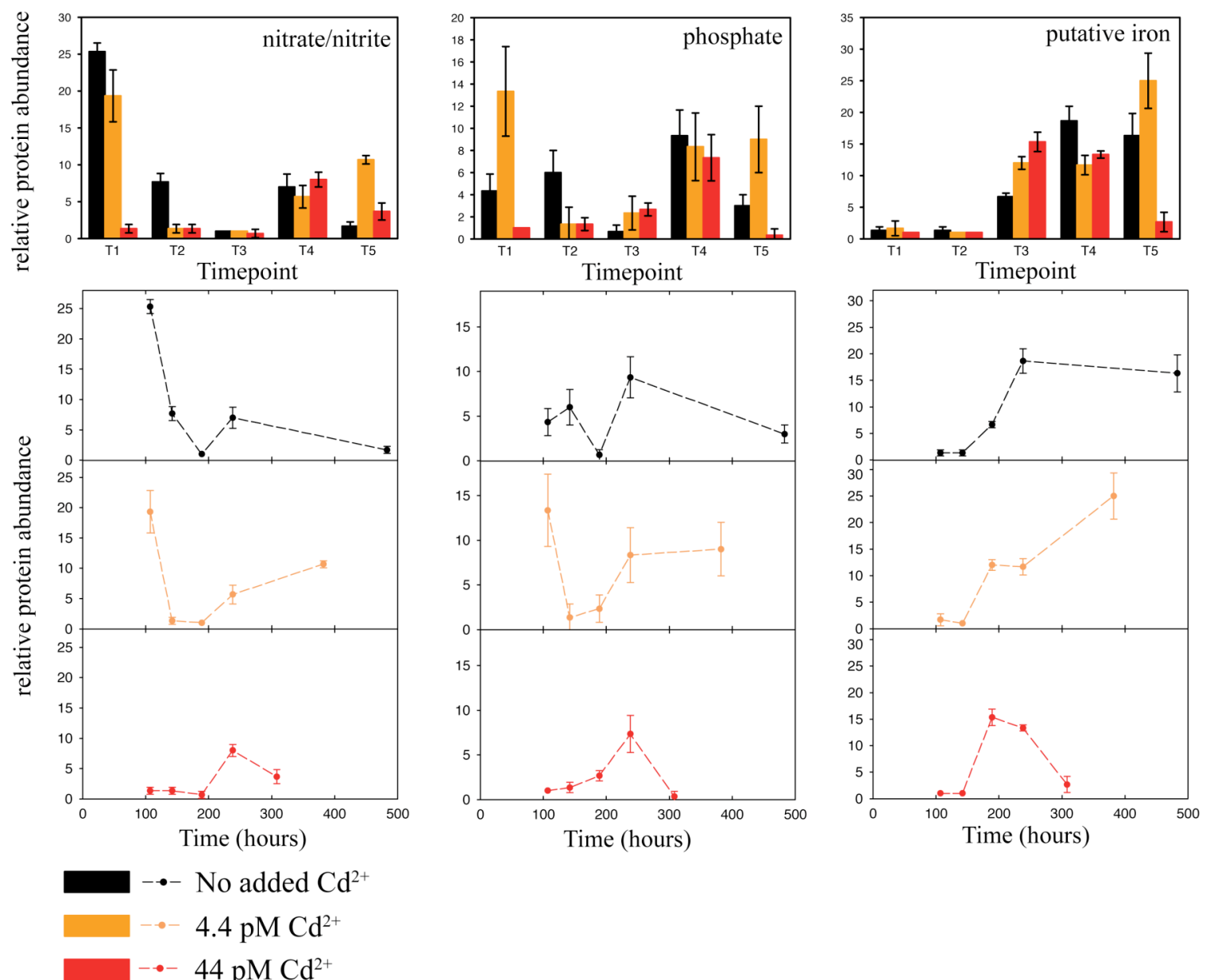

Figure 3.20: Relative abundances of other notable proteins, $\mathrm{ABC}$ transport substrate binding proteins. Error bars represent one standard deviation of triplicate injections. 


\section{Hypothetical proteins}

There are many hypothetical proteins that were $\geq$ two-fold differentially abundant between the control and at least one of the $\mathrm{Cd}$ treatments (Figure 3.21). A few of them are depicted here. The overabundance of three hypothetical proteins in stationary phase relative to exponential phase suggests the function of the hypothetical proteins may have something to do with stationary phase metabolism. One might expect this, because most researchers target their efforts towards understanding growth phase, and as a consequence stationary phase and cellular death are less well-studied in cyanobacteria. Just as there are many $\mathrm{Cd}^{2+}$ induced genes and proteins in plant and animal cells that have unknown functions (Deckert, 2005), so we observed some hypothetical proteins that appear to be related to Cd stress. Nucleotide BLAST searches on these eight proteins revealed similarities of two proteins to cyanobacterial hypothetical proteins (WH5701_14806 and WH5701_12034), a cyanobacterial pentapeptide protein (WH5701_07396), a hypothetical protein in Nitrobacter hamburgensis X14 (WH5701_09740), a $\mathrm{Na}^{+} /$alanine symporter (WH5701_10100) and three which did not show high similarity to any sequenced DNA (WH5701_04880, WH5701_09875, WH5701_08389). 

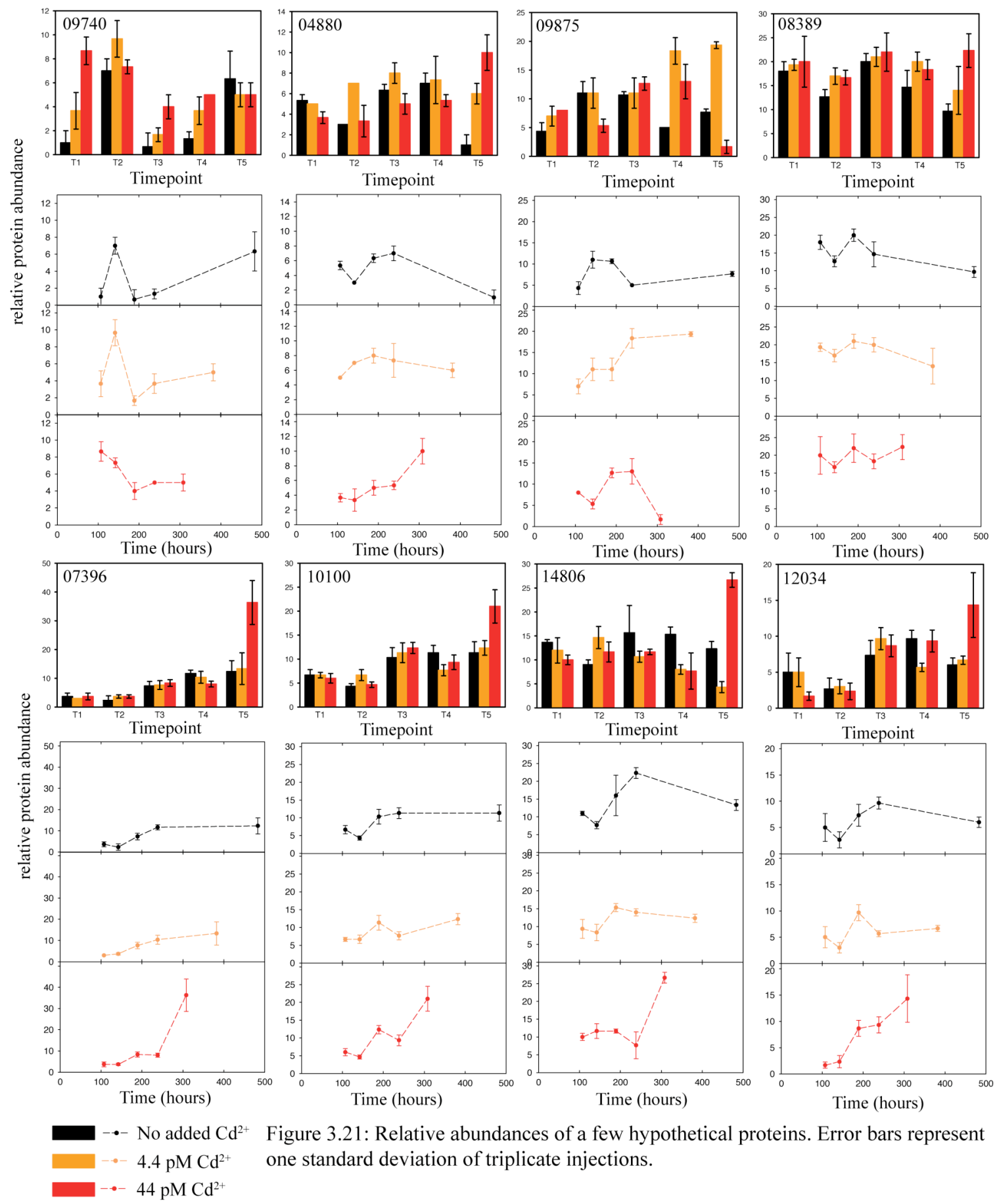

Figure 3.21: Relative abundances of a few hypothetical proteins. Error bars represent one standard deviation of triplicate injections.

\section{Proteomic Data - Overall trends throughout growth of cultures}

Considering the dataset as a progression from exponential growth phase through death phase, and how the addition of $\mathrm{Cd}^{2+}$ affects the growth phases, the no added $\mathrm{Cd}^{2+}$ treatment is the control. Because there is no $\mathrm{Zn}^{2+}$ added to the media during this 
experiment, it could be considered Zn-deprived. General trends consistent with the change in cell lifestyle from exponential growth to stationary phase in the control treatment are observed in proteins involved in protein synthesis, photosynthesis, oxidative stress, chlorophyll $a$ biosynthesis, sulfur metabolism and iron metabolism. Comparing the trends in relative abundances of proteins present in the $\mathrm{Cd}^{2+}$ treatments to the trends observed in the no added $\mathrm{Cd}^{2+}$ treatment shows that the presence of $\mathrm{Cd}^{2+}$ affects the relative abundances of proteins involved in these processes.

The relative protein abundances in the control show the presence of ribosomal proteins during early stationary phase (T2) (Figure 3.18) and not as much in other phases. This is consistent with greater protein synthesis during the transition from growth phase to stationary phase, as the cells cycle into stationary phase. One of the most striking differences with the addition of $\mathrm{Cd}^{2+}$ is the higher relative abundance of ribosomal proteins in the $\mathrm{Cd}^{2+}$ treatments compared to the no added $\mathrm{Cd}^{2+}$ during exponential growth (T1) (Figure 3.5 - Group 1, Figures 3.7, 3.18, Table 3.1). This suggests that the presence of $\mathrm{Cd}^{2+}$ is causing the upregulation of ribosomal proteins by an unknown mechanism that could perhaps be related to Zn. Despite similar physiological characteristics among the three treatments during growth phase of relative fluorescence and growth rates, the greater relative abundance of ribosomal proteins could result in increased protein synthesis in the $\mathrm{Cd}^{2+}$ treatments compared to the control during growth phase. During early stationary phase, however, the ribosomal protein relative abundances are relatively similar in the $\mathrm{Cd}^{2+}$ and the control treatments. The greater relative abundance of ribosomal proteins in the $\mathrm{Cd}^{2+}$ treatments during growth phase (T1) and the similar amounts of ribosomal proteins present in all treatments during early stationary phase (T2) could indicate an early triggering of stationary phase proteins in the $\mathrm{Cd}$ treatments relative to the control.

The presence of four photosystem II and I proteins, psbC, photosystem II chlorophyll binding protein, psaB and psaF (Figures 3.10 and 3.11) during growth (T1) and early stationary phase (T2) and not during the remainder of stationary phase (T3-T5) is consistent with cells growing, dividing and photosynthesizing during growth and early 
stationary phase and being less active during stationary phase. Culture bottles during growth phase often have gas bubbles adhering to the sides and do not during stationary phase (observations not shown), consistent with the idea of greater photosynthetic activity during growth phase. In terms of the effects of $\mathrm{Cd}^{2+}$ on the relative abundances of four photosystem II and I proteins, psbC, photosystem II chlorophyll binding protein, psaB, and psaF (Figures 3.10 and 3.11) that were present in the no added $\mathrm{Cd}^{2+}$ treatment during $\mathrm{T} 1$ and $\mathrm{T} 2$, these four proteins were present in the $4.4 \mathrm{pM} \mathrm{Cd}^{2+}$ treatment greater than or equal to six spectral counts during only T1 and never greater than 1 spectral count for the $44 \mathrm{pM} \mathrm{Cd}^{2+}$ treatment. This suggests that $44 \mathrm{pM} \mathrm{Cd}^{2+}$ negatively affects the presence of these proteins, perhaps impairing the process of photosynthesis and leading to a premature death of the culture. This is despite the physiological similarity of the cultures during growth (T1).

The relative abundance of superoxide dismutase increases from growth through mid-stationary phase (T1-T3) and remains constant throughout the rest of stationary phase (T4 and T5) (Figure 3.17). This suggests that the culture experienced increasing oxidative stress from T1-T3, the amount of oxidative stress perhaps remaining constant for the remainder of stationary phase (T4 and T5). The effects of $\mathrm{Cd}^{2+}$ on superoxide dismutase are less clear. The relative abundance of superoxide dismutase in both $\mathrm{Cd}^{2+}$ treatments was similar to the control during growth (T1) and early stationary phase (T2) and highest during mid-stationary phase (T3). Unlike the control, in which the relative abundance remained constant, the relative abundance of superoxide dismutase decreased for late stationary (T4) and death phase (T5). This suggests that $\mathrm{Cd}^{2+}$ affects the level of oxidative stress in the cells, or the signaling inside the cells that recognizes oxidative stress. Perhaps these differences in superoxide dismutase relative abundances reflect the earlier and faster death of the cultures with added $\mathrm{Cd}^{2+}$.

The five detected proteins involved in the biosynthesis of chlorophyll $a$ overall had greater abundances during early stationary phase (T2), otherwise were of lower abundance (Figure 3.8). $\mathrm{Cd}^{2+}$ affects the relative abundances of proteins involved in the chlorophyll $a$ biosynthesis pathway, as discussed above (see chlorophyll biosynthesis). 
An arylsulfatase and a putative arylsulfatase were not abundant during exponential growth (T1) and were the most abundant during early stationary phase (T2) suggesting a shifting of sulfur metabolism into stationary phase (Figure 3.15 ). $\mathrm{Cd}^{2+}$ affects these proteins, also as discussed above (see arylsulfatases). A putative iron $\mathrm{ABC}$ transport substrate binding protein was more abundant during mid-stationary to very late stationary (T3-T5) (Figure 3.20). This could suggest increasing iron stress throughout the life of the culture, as discussed above (see other proteins). Overall, the regulation of photosynthesis and cell death may be correlated and related to the presence of metals, especially $\mathrm{Zn}$.

\section{Synechococcus WH5701 compared to Chlamydomonas reinhardtii cadmium response}

The comparison of the proteome response of this marine unicellular photosynthetic cyanobacterium, Synechococcus WH5701 (this study) with the freshwater unicellular photosynthetic algae, Chlamydomonas reinhardtii (Gillet et al., 2006) shows that these organisms react quite differently to chronic Cd stress. Although there are three orders of magnitude more total $\mathrm{Cd}$ added to Chlamydomonas reinhardtii than Synechococcus WH5701 and the toxicity thresholds are quite different in these two organisms, the comparison yields useful insight.

Cells exposed to $150 \mu \mathrm{M} \mathrm{Cd}$ in Chlamydomonas reinhardtii showed a decrease in abundance of the large and small subunits of ribulose-1,5-bisphosphate carboxylase/oxygenase as well as other enzymes utilized in photosynthesis, the Calvin cycle and chlorophyll biosynthesis (Gillet et al., 2006). During growth phase, we detected the small subunit of ribulose-1,5-bisphosphate carboxylase/oxygenase, but saw no relative change. We observed an increase, not a decrease in chlorophyll biosynthesis proteins. Similar to $C$. reinhardtii we observed a decrease in PSI proteins and carbon fixation related proteins. Also decreased in abundance in C. reinhardtii were proteins involved in fatty acid, amino acid, and protein biosynthesis (Gillet et al., 2006). Contrary to $C$. reinhardtii we observed an increase in proteins related to amino acid and protein biosynthesis in WH5701. We did observe decreased abundance of some hypothetical proteins, although their functions remain unknown.

Proteins more abundant with the presence of $150 \mu \mathrm{M} \mathrm{Cd}$ in Chlamydomonas 
reinhardtii were those involved in glutathione synthesis, ATP metabolism, oxidative stress, and protein folding (Gillet et al., 2006). Most of the Cd sensitive proteins were regulated through thioredoxin and glutaredoxin, two major cellular thiol redox systems (Gillet et al., 2006). Of the 26 proteins less abundant by at least a factor of 1.5 in the presence of $\mathrm{Cd}$ in $C$. reinhardtii, we could identify 13 of these proteins during exponential growth in WH5701, 11 with spectral counts of at least four. Of these 11 proteins, $\mathrm{Cd}^{2+}$ in WH5701 did not affect 5 and 6 were actually more abundant in $\mathrm{Cd}^{2+}$ treatments by at least a factor of 1.5 . Of the 16 proteins more abundant by at least a factor of 1.5, excluding ATP synthase subunits in the presence of $\mathrm{Cd}$ in $C$. reinhardtii, we could identify 5 proteins in exponential growth in WH5701, only 2 with spectral counts of at least 4. Of these two proteins, glutathione S-transferase was not affected by $\mathrm{Cd}$ in WH5701 and inorganic pyrophosphatase was also more abundant in Cd treatments by a factor of 1.2 and 1.6 for 4.4 and $44 \mathrm{pM} \mathrm{Cd}^{2+}$, respectively. Various ATP synthase subunits were more abundant in $C$. reinhardtii with the addition of $\mathrm{Cd}$. Unlike in $C$. reinhardtii, 6 various subunits of ATP synthase observed in WH5701, with spectral counts of at least four, Cd caused a decrease in abundance in the $44 \mathrm{pM} \mathrm{Cd}^{2+}$ treatment and a slight increase in the $4.4 \mathrm{pM} \mathrm{Cd}^{2+}$ treatment for four of the subunits. The remaining two subunits of ATP synthase remained the same as the control at the $4.4 \mathrm{pM}$ $\mathrm{Cd}^{2+}$ treatment and decreased with the $44 \mathrm{pM} \mathrm{Cd}^{2+}$.

\section{Synechococcus WH5701 comparison to a marine bacterium stationary phase response}

Sowell et al., 2008 studied the proteome response of the marine bacterium Candidatus Pelagibacter ubique to stationary phase. They found that this organism increases the abundance of a few proteins that contribute to cellular homeostasis rather than remodeling the entire proteome upon adaptation to stationary phase (Sowell et al., 2008). The proteins that increased in abundance were OsmC and thioredoxin reductase (these two proteins may decrease oxidative damage), molecular chaperones, enzymes involved in methionine and cysteine biosynthesis, proteins involved in rho-dependent transcription termination and the signal transduction enzyme CheY-FisH (Sowell et al., 2008). Similarly, in stationary phase compared to exponential, we observed an increase 
in superoxide dismutase (Figure 3.17), which mitigates oxidative damage and Sadenosylmethionine synthetase, a protein involved in methionine and cysteine biosynthesis (Figure 3.16).

\section{Environmental Relevance of Results}

This experiment was performed on cell cultures with environmentally relevant concentrations of trace metals. The concentrations of $\mathrm{NO}_{3}{ }^{-}(1.1 \mathrm{mM})$ and $\mathrm{PO}_{4}{ }^{3-}(65 \mu \mathrm{M})$, however, were higher than those normally measured in the environment, deliberately in order to not limit the cells for these major nutrients, and to produce high densities of cells for protein analysis in a reasonable amount of time using a reasonable amount of oligotrophic seawater.

Death of phytoplankton in the sea is generally attributed to grazing or predation (Walsh, 1983), so the laboratory study of stationary and death phase can perhaps be considered to have been neglected. More recently, the presence of proteases coincident with cell death in cultures of diatoms suggested the importance of cell death processes to cycling of organic matter in aquatic ecosystems (Berges and Falkowski, 1998). Programmed cell death has been documented in several phytoplankton species, including the dinoflagellete, Peridinium gatunense, in which an excreted thiol protease is thought to coordinate cell death in culture and in blooms in the environment (Vardi et al., 2007).

As oceans change Synechococcus WH5701 could be an important cyanobacterial strain due to its robustness (variable salinity and nutrient tolerances). As of now, naturally-occurring chronic $\mathrm{Cd}$ stress to cyanobacteria could really only have the chance to be observed in upwelling regions and maybe some coastal, and as it is the presence of $\mathrm{Zn}$ and organic ligands in upwelling regions would serve to buffer the toxicity of $\mathrm{Cd}$ in most instances. In general, the presence of complex microbial communities probably would alleviate most potential for Cd stress, due to differential uptake, adsorption to surfaces, and complexation with ligands. Higher dissolved Cd concentration can sometimes be observed in oligotrophic waters (Noble et al., unpublished data). 


\section{CONCLUSIONS}

In conclusion, in the absence of added $\mathrm{Zn}$, chronic $\mathrm{Cd}^{2+}$ exposure has a major impact on the metabolism of WH5701, as evidenced by dramatic changes in the relative protein abundances. Changes are evidenced in proteins involved in chlorophyll $a$ biosynthesis, photosynthesis (phycobilisome, photosystem II, photosystem I), carbon fixation (carboxysome, Calvin cycle, others), steroid and lipid biosynthesis, sulfur and/or cysteine metabolism, oxidative stress, genetic information processing and others, suggesting that $\mathrm{Cd}^{2+}$ affects the fundamental functioning of the cell. Changes in hypothetical proteins are also evinced. Physiological measurements during growth phase show little difference between $\mathrm{Cd}^{2+}$ treatments and the control, yet based on changes in protein relative abundances, cells are affected by chronic $\mathrm{Cd}^{2+}$ stress. Chronic $\mathrm{Cd}^{2+}$ increases the abundance of arylsulfatases, which have been noted to increase in cells that are experiencing sulfur starvation, and other proteins involved in the making of cysteine, an amino acid involved in thiols, metallothioneins and sulfur metabolism. In addition, measurement of particulate glutathione, a low molecular weight thiol, in a repeat experiment showed a large quantity of this metabolite in the high $\mathrm{Cd}^{2+}$ treatment.

Relative protein abundances also yielded insights into the observed physiological changes in the $\mathrm{Cd}^{2+}$ treatments during stationary and death phases. Changes in relative abundances of chlorophyll biosynthesis proteins may help explain the increase in chlorophyll $a$ maximum observed in the $\mathrm{Cd}$ treatments. The strong effect of $\mathrm{Cd}$ on cellular metabolism may help explain the early death in the $\mathrm{Cd}$ treatments compared to the control. The physiological effects of increased maximum chlorophyll $a$ fluorescence and faster mortality with the addition of picomolar free $\mathrm{Cd}^{2+}$ were not observed when picomolar free $\mathrm{Zn}^{2+}$ was present in the media. This suggests that the presence of $\mathrm{Zn}^{2+}$ alleviated $\mathrm{Cd}^{2+}$ toxicity and $\mathrm{Cd}^{2+}$ may have been affecting $\mathrm{Zn}^{2+}$ systems when $\mathrm{Zn}^{2+}$ was absent.

Comparison of the reaction of WH5701 to chronic Cd stress in an eukaryotic algae $C$. reinhardtii showed both similarities and differences in terms of changes in relative protein abundances. Some proteins changed in abundance in a similar way, 
including similar decreases in PSI proteins and carbon fixation related proteins. Overall however, these two unicellular photosynthetic organisms reacted differently to chronic Cd stress: WH5701 was observed to have an increase in chlorophyll a, amino acid and protein biosynthesis proteins, whereas $C$. reinhardtii showed a decrease in proteins of these biosynthesis functions.

This study also examined the change in the proteome from exponential growth throughout stationary phase documenting the decrease in the relative abundances of ribosomal proteins, among others and increase in superoxide dismutase, among others from exponential throughout stationary phase. In addition, this study also identified many hypothetical proteins of unknown function, which change in abundance from growth to stationary phase and with $\mathrm{Cd}$ stress. This gives insight into the possible function of these proteins for future investigation.

These experiments were performed in continuous light with replete macronutrients, and although $\mathrm{NO}_{3}{ }^{-}$and $\mathrm{PO}_{4}{ }^{3-}$ concentrations were higher than those found in the environment, clues about the functioning of cyanobacteria in the greater ocean ecosystem can be gleaned. Our results indicate that cyanobacteria are versatile and can survive in changing environmental conditions by adjusting their cellular functioning as discerned by analyzing differences in their relative protein abundances. In the ocean, free-floating cyanobacteria existing in the mixed layer may be exposed to different light, nutrient, and metal concentrations, as well as a changing microbial consortium.

\section{FUTURE DIRECTIONS}

The physiological effects of increased maximum chlorophyll $a$ fluorescence of $\mathrm{Cd}^{2+}$ treatments above the control and the faster death rates disappear with the presence of $\mathrm{Zn}^{2+}$ added to the media. To see whether the presence of $\mathrm{Zn}^{2+}$ buffers $\mathrm{Cd}^{2+}$ toxicity on a cellular level, this experiment could be performed with $\mathrm{Zn}^{2+}$ added to the media. Perhaps the carboxysome proteins would not be affected by $44 \mathrm{pM} \mathrm{Cd}^{2+}$ as they were in this experiment without $\mathrm{Zn}^{2+}$ in the media.

Intriguing is the possibility that $\mathrm{Cd}^{2+}$ triggers apoptosis. There are no annotated 
caspases in WH5701. All possible caspases could be easily cataloged and blasted against the WH5701 genome at the nucleotide level. Any hits could be added to our WH5701 database and see if we detected those proteins.

Despite the detection of many carboxysome protein components, no carbonic anhydrases were detected. Since the only known nutritive use of $\mathrm{Cd}$ is in a carbonic anhydrase of T. weissflogii (Lane and Morel, 2000; Lane et al., 2005; Park et al., 2007; $\mathrm{Xu}$ et al., 2008), detection of this protein is desirable. As a simple first pass, the carbonic anhydrase might be in a different protein fraction. During protein extraction, after resuspension of the harvested cell pellet in one $100 \mu \mathrm{M}$ ammonium bicarbonate, sonication and centrifugation, only about half of the supernatant was acetone precipitated. The remainder of the supernatant was evaporated by speed vacuum, stored overnight at $80^{\circ} \mathrm{C}$ and then extracted and digested with the acetone-precipitated samples. This means that this additional protein fraction is safely in the $-80^{\circ} \mathrm{C}$, ready for mass spectrometric global proteomic analysis.

The further investigation of PSII/PSI ratios and how these systems are regulated would be interesting because it is flexible. PSII core protein D2 was detected at the highest count of 3. A putative PSII reaction center Psb28 at the highest count of 18 and PSII complex extrinsic protein PsuB at the highest count of 42 were detected. Both of these have the greatest abundance during the $44 \mathrm{pM} \mathrm{Cd}^{2+}$ death phase $\mathrm{T} 5$. This suggests that $\mathrm{Cd}$ interferes with regulation at $\mathrm{T} 5 \mathrm{in}$ high $\mathrm{Cd}$. A similar pattern is observed in a few carboxysome proteins, PSI proteins, among others. These two PSII proteins do not show an increase in relative protein abundance in the no added $\mathrm{Cd}$ treatment during the decrease in cell counts observed from $\mathrm{T} 3$ to $\mathrm{T} 4$.

Also of note is the relationship observed in Figure 4.4d between dose of $\mathrm{Cd}$ and the ratio of chlorophyll $a$ /phycoerythrin fluorescence. It can be used as a biosenser for $\mathrm{Cd}$ at concentrations as low as $0.44 \mathrm{pM} \mathrm{Cd}^{2+}$ (data not shown), except that it does not hold in the presence of $\mathrm{Zn}$, rendering its practicality moot. Note that there are fluorescence-based biosensors for $\mathrm{Zn}$ that utilize carbonic anhydrase (see work of Richard B. Thompson). 


\section{Acknowledgements}

I would like to thank the members of the Saito Lab: Dawn Moran, Abigail Noble, Tyler Goepfert and Erin Bertrand. Thank you to John Waterbury and Freddie Valois for the WH5701, use of lab space, and discussion. Thank you to Tristan Kading for discussion and thiol measurements and Tracey Mincer for discussion.

\section{References}

Altschul, S. F., Madden, T. L., Schaffer, A. A., Zhang, J., Zhang, Z., Miller, W. and Lipman, D. J. 1997. Gapped BLAST and PSI-BLAST: a new generation of protein database search programs. Nucleic Acids Research 25: 3389-3402.

Bailey, S., Melis, A., Mackey, K. R. M., Cardol, P., Finazzi, G., van Dijken G., Berg, G. M., Arrigo, K., Shrager, J., Grossman, A. 2008. Alternative photosynthetic electron flow to oxygen in marine Synechococcus. Biochimica et Biophysica Acta-Bioenergetics 1777 (3): 269-276.

Berges, J. A. and Falkowski, P.G. 1998. Physiological stress and cell death in marine phytoplankton: Induction of proteases in response to nitrogen or light limitation. Limnology and Oceanography 43(1): 129-135.

Beutler, M. 2003. Spectral fluorescence of chlorophyll and phycobilins as an in-situ tool of phytoplankton analysis - models, algorithms and instruments. Christian-AlbrechtsUniversität, phD-Thesis.

Blankenship, R. E. 2002. Molecular Mechanisms of Photosynthesis. Oxford: Blackwell Science.

Campbell, D., Hurry, V., Clarke, A. K., Gustafsson, P. and Öquist, G. 1998. Chlorophyll fluorescence analysis of cyanobacterial photosynthesis and acclimation. Microbiology Molecular Biology Reviews 62: 667-683.

Deckert, J. 2005. Cadmium toxicity in plants: Is there any analogy to its carcinogenic effect in mammalian cells? Biometals 18: 475-481.

Duncan, K.E.R., Ngu, T.T., Chan, J., Salgado, M.T., Merrifield, M.E. and Stillman, M.J. 2006. Peptide folding, metal-binding mechanisms, and binding site structures in metallothioneins. Experimental Biology and Medicine 231: 1488-1499.

Dupont, C.L. and Ahner, B. 2005. Effects of copper, cadmium, and zinc on the production and exudation of thiols by Emiliania huxleyi. Limnology and Oceanography 50(2):508-515. 
Dupont C.L., Yang S., Palenik B., Bourne, PE. 2006. Modern proteomes contain putative imprints of ancient shifts in trace metal geochemistry. Proceedings of the National Academy of Sciences 103 (47): 17822-17827.

Dupont, C.L., Moffett, J.W., Bidigare R.R. and Ahner, B.A. 2006. Distributions of dissolved and particulate biogenic thiols in the subartic Pacific Ocean. Deep Sea Research Part I: Oceanographic Research Papers 53(12): 1961-1974.

Eisen, M.B., Spellman, P.T., Brown, P.O. and Bostein, D. 1998. Cluster analysis and display of genome-wide expression patterns. PNAS 95(25): 14863-14868.

Ellis, J.R. 1979. The most abundant protein in the world. Trends in Biochemical Sciences 4(11): 241-244.

Everroad, C., Six, C., Partensky, F., Thomas, J. C., Holtzendorff, J. and Wood, A. M. 2006. Biochemical bases of type IV chromatic adaptation in marine Synechococcus spp. Journal of Bacteriology 188 (9): 3345-3356.

Fitzgerald, J. W. 1976. Sulfate ester formation and hydrolysis: a potentially important yet often ignored aspect of the sulfur cycle of aerobic soils. Bacteriological Reviews 40 (3): 698-721.

Fuller, N.J., Marie, D., Partensky, F., Vaulot, D., Post, A.F. and Scanlan, D. J. 2003. Clade-specific 16S Ribosomal DNA oligonucleotides reveal the predominance of a single marine Synechococcus clade in a stratified water column in the Red Sea. Applied and Environmental Microbiology 69: 2430-2443.

Gillet, S., Decottignies, P., Chardonnet, S. and Le Maréchal, P. 2006. Cadmium response and redoxin targets in Chlamydomonas reinhardtii: a proteomic approach. Photosynthesis Research 89: 201-211.

Goldschmidt, V.M. 1954. edited by Alex Muir. Geochemistry. Oxford at Clarendon Press.

Goloubinoff, P., Christeller, J.T., Gatenby, A.A. and Lorimer, G.H 1989. Reconstitution of active dimeric ribulose bisphosphate carboxylase from an unfoleded state depends on two chaperonin proteins and Mg-ATP. Nature 342: 884-889.

Haverkamp, T., Schouten, D., Doeleman, M., Wollenzien U., Huisman, J. and Stal, L. J. 2009. Colorful microdiversity of Synechococcus strains (picocyanobacteria) isolated from the Baltic Sea. The ISME Journal 3: 397-408. 
Kerfeld, C. A., Sawaya, M. R., Tanaka, S., Nguyen, C. V., Phillips, M., Beeby, M. and Yeates, T.O. 2005. Protein structures forming the shell of primitive bacterial organelles. Science 309 (5736): 936-938.

Küpper, H., Küpper, F. and Spiller, M. 1996. Environmental relevance of heavy metalsubstituted chlorophylls using the example of water plants. Journal of Experimental Botany 47: 259-266.

Küpper, H., Küpper, F. and Spiller, M. 1998. In situ detection of heavy metal substituted chlorophylls in water plants. Photosynthesis Research 58: 123-133.

Lane, T.W. and Morel, F.M.M. 2000. A biological function for cadmium in marine diatoms. Proceedings of the National Academy of Sciences 97: 4627-4631.

Lane, T.W., Saito, M.A., George, G.N., Pickering, I.J., Prince, R.C. 2005. A cadmium enzyme from a marine diatom. Nature 435: 42.

MacColl, R. 1998. Cyanobacterial phycobilisomes. Journal of Structural Biology 124: 311-334.

Margoshes, M. and Vallee, B.L. 1957. A cadmium protein from equine kidney cortex. Journal of the American Chemical Society 79: 4813-4814.

Martell, A.E. and Smith, R. M. 1993. NIST Critical Stability Constants of Metal Complexes Database.

Martelli, A. E. Rousselet, Dycke, C., Bouron, A. and Moulis, J.-M. 2006. Cadmium toxicity in animal cells by interference with essential metals. Biochimie 88 (11):18071814.

Morel, F.M.M., Milligan, A.J., and Saito, M.A. 2004. Marine Bioinorganic Chemistry: The Role of Trace Metals in the Oceanic Cycles of Major Nutrients. Treatise on Geochemistry Volume 6 The Oceans and Marine Geochemistry. eds. Henry Elderfield. H.D. Holland and K.K. Turekian. 6.05 113-143.

Mullineaux, C,W. 1999. The thylakoid membranes of cyanobacteria: structure dynamics and function. Australian Journal of Plant Physiology 26: 671-677.

Okamura, M. Y., Paddock, M. L., Graige, M. S., and Feher, G. 2000. Proton and electron transfer in bacterial reaction centers. Biochimica et Biophysica Acta-Bioenergetics. 1458 (1): 148-163.

Palenik, B. 2001. Chromatic adaptation in marine Synechococcus strains. Applied and Environmental Microbiology 67(2): 991-994. 
Palmiter, R.D. 1998. The elusive function of metallothioneins. PNAS 95: 8428-8430.

Park, H., Song, B. and Morel, F. M. M. 2007. Diversity of the cadmium-containing carbonic anhydrase in marine diatoms and natural waters. Environmental Microbiology 9(2): 403-413.

Peng, J., Elias, J. E., Thoreen, C. C., Licklider, L. J. and Gygi, S. P. 2003. Evaluation of multidimensional chromatography coupled with tandem mass spectrometry (LC/LCMS/MS) for large-scale protein analysis: The Yeast Proteome. Journal of Proteome Research 2: 43-50.

Saito, M., Moffett, J.W., Chisholm, S.W., and Waterbury, J.B. 2002. Cobalt limitation and uptake in Prochlorococcus. Limnology and Oceanography 47(6): 1629-1636.

Saito, M.A., Sigman, D.M., Morel, F.M.M. 2003. The bioinorganic chemistry of the ancient ocean: the co-evolution of cyanobacterial metal requirements and biogeochemical cycles at the Archean-Proterozoic boundary? Inorganica Chimica Acta 356:308-318.

Scanlan, D.J. 2003. Physiological diversity and niche adaptation in marine Synechococcus. Advances in Microbial Physiology 47: 1-64.

Schubert, W.D., Klukas, O., Krauss, N., Saenger, W., Fromme, P. and Witt, H.T. 1997. Photosystem I of Synechococcus elongatus at 4 A resolution: comprehensive structure analysis. Journal of Molecular Biology 272 (5): 741-769.

Semeniuk, D.M., Cullen, J.T., Johnson, W.K., Gagnon, K., Ruth, T.J. and Maldonado, M.T. 2009. Plankton copper requirements and uptake in the subarctic Northeast Pacific Ocean. Deep Sea Research I 56, 1130-1142.

Silver, S., and M. Wauderhaug, 1992. Gene regulation of plasmid- and chromosomedetermined inorganic ion transport in bacteria. Microbiological Reviews. 56:195-264.

Six, C., Finkel, Z. V., Irwin, A. J., Campbell, D. A. 2007. Light variability illuminates niche-partitioning among marine picocyanobacteria. PLoS ONE 2(12): e1341. doi:10.1371/journal.pone.0001341.

Sowell, S. M., Norbeck, A. D., Lipton, M. S., Nicora, C. D., Callister, S. J., Smith, R. D., Barofsky, D. F., and Giovannoni, S. J. 2008. Proteomic analysis of stationary phase in the marine bacterium "Candidatus Pelagibacter ubique". Applied and Environmental Microbiology 74 (13): 4091-4100.

Sujak, A. 2005. Interaction between cadmium, zinc and silver-substituted platocyanin and cytochrome $b_{6}$ f complex-heavy metals toxicity towards photosynthetic apparatus. Acta 
Physiologiae Plantarum 27(1):61-69.

Sunda, W.G. 1988. Trace metal interactions with marine phytoplankton. Biology and Oceanography 6: 411-442.

Sunda, W.G., and Huntsman, S.A. 2000. Effect of Zn, Mn, and Fe on Cd accumulation in phytoplankton: Implications for oceanic Cd cycling. Limnology and Oceanography 45(7): 1501-1516.

Sunda, W.G. and Huntsman, S.A.1995. Cobalt and zinc interreplacement in marine phytoplankton: biological and geochemical implications. Limnology and Oceanography 40(8): 1404-1417.

Sunda, W.G., and Hunstman, S.A.1998. Control of Cd concentrations in a coastal diatom by interactions among free ionic $\mathrm{Cd}, \mathrm{Zn}$, and $\mathrm{Mn}$ in seawater. Environmental Science and Technology 32: 2961-2968.

Tang, D., Hung, C., Warnken, K. W. and Santschi, P. H. 2000. The distribution of biogenic thiols in surface waters of Galveston Bay. Limnology and Oceanography 45(6): 1289-1297.

Ting, C.S., Rocap, G., King, J. and Chisholm, S.W. 2002. Cyanobacterial photosynthesis in the oceans: the origins and significance of divergent light-harvesting strategies. Trends in Microbiology 10 (3): 134-142.

Tokheim, A. M., Spannaus-Martin, D. J., and Martin, B.L. 2005. Evidence for the $\mathrm{Cd}^{2+}$ activation of the aryl sulfatase from helix pomatia. BioMetals 18: 537-540.

Vallee, B.L. and Ulmer, D.D.1972. Biochemical effects of mercury, cadmium and lead. Annual Review of Biochemistry 41: 91-128.

Van Mooy, B. A.S. 2006. Rocap, G., Fredricks, H. F., Evans, C.T. and Devol, A. H. 2006. Sulfolipids dramatically decrease phosphorus demand by picocyanobacteria in oligotrophic marine environments. PNAS 103 (23): 8607-8612.

Vardi, A., Eisenstadt, D., Murik, O., Berman-Frank, I., Zohary, T., Levine, A. and Kaplan, A. 2007. Synchronization of cell death in a dinoflagellate population is mediated by an excreted thiol protease. Environmental Microbiology 9(2): 360-369.

Wakao, N., Yokoi, N., Isoyama, N., Hiraishi, A., Shimada, K., Kobayashi, M., Kise, H., Iwaki, M., Itoh, S. and Takaichi, S. 1996. Discovery of natural photosynthesis using Zncontaining bacteriochlorophyll in an aerobic bacterium Acidiphilium rubrum. Plant and Cell Physiology 37 (6): 889-893. 
Waldron, K. J., Rutherford, J. C., Ford, D. and Robinson, N.J. 2009. Metalloproteins and metal sensing. Nature 460: 823-830.

Xu, Y., Feng, L., Jeffrey, P. D., Shi, Y. and Morel, F. M. M. 2008. Structure and metal exchange in the cadmium carbonic anhydrase of marine diatoms. Nature 452: 56-61.

Yeates, T. O, Kerfeld, C. A., Heinhorst, S., Cannon, G.C. and Shively, J. M. 2008. Protein-based organelles in bacteria: carboxysomes and related microcompartments. Nature Reviews Microbiology 6: 681-691.

Zhang, B., VerBerkmoes, N. C., Langston, M.A., Uberbacher, E., Hettich, R. L. and Samatova, N. F. 2006. Detecting differential and correlated protein expression in labelfree shotgun proteomics. Journal of Proteome Research 5(11): 2909-2918.

Zhang, Z., Shrager, J., Jain, M., Chang, C., Vallon, O. and Grossman, A. R. 2004. Insights into the survival of Chlamydomonas reinhardtii during sulfur starvation based on microarray analysis of gene expression. Eukaryotic Cell 3(5): 1331-1348. 


\title{
Chapter 4
}

\section{Oceanic Synechococcus WH8102 physiological and proteomic response to acute cadmium addition under zinc deficient and low phosphate conditions}

\begin{abstract}
Synechococcus sp. WH 8102 is a motile marine cyanobacterium isolated originally from the Sargasso Sea. It is adapted to the open ocean with lower trace metal availability and low variability in irradiance with deep mixed layer depths relative to coastal waters. To test the response of this organism to free cadmium $(\mathrm{Cd})$, generally considered a toxin, four cultures were grown in a matrix of high and low zinc $(\mathrm{Zn})$ and phosphate $\left(\mathrm{PO}_{4}{ }^{3-}\right)$ and were acutely exposed to $4.4 \mathrm{pM}$ free $\mathrm{Cd}^{2+}$ during mid-log phase and harvested after $24 \mathrm{~h}$. Cell number, relative chlorophyll $a$ and phycoerythrin fluorescence were monitored throughout growth phase, where $\mathrm{Zn}$ and $\mathrm{PO}_{4}{ }^{3-}$ had little effect on growth rates, but in the final $24 \mathrm{~h}$ of the experiment three effects were noticed: 1) low $\mathrm{PO}_{4}{ }^{3-}$ treatments showed increased instantaneous growth rates relative to high $\mathrm{PO}_{4}{ }^{3-}$ treatments, 2) the $\mathrm{Zn}$-high $\mathrm{PO}_{4}{ }^{3-}$ treatment appeared to enter stationary phase, and 3) Cd increased growth rates even more in the both the low $\mathrm{PO}_{4}{ }^{3-}$ and $\mathrm{Zn}$ treatments. Global proteomic analysis of relative protein abundance revealed that: 1) $\mathrm{Zn}$ appeared to be vital to the $\mathrm{PO}_{4}{ }^{3-}$ response in this organism, 2) Cd caused more proteomic changes at low $\mathrm{PO}_{4}{ }^{3-}$, and 3 ) in the presence of both replete $\mathrm{PO}_{4}{ }^{3-}$ and acute $\mathrm{Cd}$ the proteome was almost indifferent to the presence of $\mathrm{Zn}$. Comparison to a literature transcriptome study of $\mathrm{PO}_{4}{ }^{3-}$ stress in this organism grown in a media containing $\mathrm{Zn}$ by Tetu et al., 2009 showed a similar $\mathrm{PO}_{4}{ }^{3-}$ response in the presence of Zn, including the greater relative abundance of SYNW2391 alkaline phosphatase, SYNW1018 ABC phosphate binding protein (PstS) and other proteins. In the absence of $\mathrm{Zn}$ in this experiment, however, the $\mathrm{PO}_{4}{ }^{3-}$ response is remarkably different. In addition, SYNW0359 bacterial metallothionein (SmtA) appears correlated with $\mathrm{PO}_{4}{ }^{3-}$ stress-associated proteins.
\end{abstract}




\section{INTRODUCTION}

Synechococcus WH8102 is a well-studied isolate of cyanobacteria, belonging to the marine cyanobacterial subcluster 5.1, MC-A group. It was originally isolated from the Sargasso Sea and the fully sequenced genome is available (Palenik et al., 2003). The MC-A group is thought to be the dominant Synechococcus group within the euphotic zone of open ocean and coastal waters (Fuller et al., 2003 and references therein). Previous culture studies of this organism showed that at low zinc $(\mathrm{Zn})$ concentrations cadmium $(\mathrm{Cd})$ lowered growth rates, whereas this was not observed at higher $\mathrm{Zn}$ concentrations (Saito et al., 2003).

As discussed in Chapter 1 on pages 15-16, Cd and Zn have nutrient-like distributions in the ocean, implying that $\mathrm{Cd}$ and $\mathrm{Zn}$ are taken up by microorganisms in the surface water and remineralized at depth. Zn is vitally important to the proper functionality of many enzymes, an essential metal in living organisms, whereas $\mathrm{Cd}$ is not.

These metals may have different roles in different environments. $\mathrm{Zn}$ is considered a nutrient in the open ocean. Zn availability, for instance, may influence phytoplankton diversity in the Ross Sea (Saito et al., 2010). In cyanobacteria, the Zn requirements are very low, consistent with the idea that cyanobacteria may have evolved in a sulfidic ancient ocean (Saito et al., 2003). There are almost no studies of Zn handling mechanisms in marine cyanobacteria (Blindauer, 2008). In terms of $\mathrm{Cd}$, it has been noticed that the dissolved $\mathrm{Cd}: \mathrm{PO}_{4}{ }^{3-}$ ratios are lower in the surface waters of Felimited regions, implying preferential removal of $\mathrm{Cd}$ relative to $\mathrm{PO}_{4}{ }^{3-}$ in Fe-limited waters (Cullen, 2006; Lane et al., 2009, references therein).

As stated, dissolved $\mathrm{Cd}$ and $\mathrm{PO}_{4}{ }^{3-}$ are correlated in the ocean, but $\mathrm{Zn}$ and phosphorus could be colimiting in some areas of the ocean. Phosphorus is an essential nutrient, utilized in the cell for purposes ranging from the backbone of DNA to the energy currency of a cell, adenine triphosphate, ATP. It is typically found at low micromolar concentrations in the ocean and is limiting in some regions. It composes some $2-4 \%$ dry weight of cells and is considered by some to be the 'staff of life' (Karl, 2000). Considering $\mathrm{Zn}$ and phosphorus together, they are thought to exhibit Type III 
biochemically dependent colimitation, i.e. the uptake of one nutrient, phosphorus, is dependent upon adequate nutrition with regard to the other, Zn (Saito et al, 2008). Based on extrapolation of experimentation with the coccolithophore, Emiliania huxleyi, $\mathrm{Zn}$ and phosphorus colimitation could occur in highly oligotrophic regions such as the Sargasso Sea (Shaked et al., 2006).

In this paper, the physiological and proteomic responses of the open ocean Synechococcus WH8102 to acute Cd exposure under varying chronic $\mathrm{Zn}$ and $\mathrm{PO}_{4}{ }^{3-}$ concentrations was examined. Physiological results indicated that all treatments had similar growth rates throughout the first 10 days of the experiment until $\mathrm{Cd}$ addition, but in the last 24 hours of the experiment, low $\mathrm{PO}_{4}{ }^{3-}$ treatments showed increased instantaneous growth rates relative to high $\mathrm{PO}_{4}{ }^{3-}$ treatments. Also, the acute addition of $\mathrm{Cd}$ increased instantaneous growth rates further above those in both the low $\mathrm{PO}_{4}{ }^{3-}$ and $\mathrm{Zn}$ treatments. Global proteomic results showed a response to lowered $\mathrm{PO}_{4}{ }^{3-}$ in the presence of $\mathrm{Zn}$ similar to previous transcriptome studies, including a greater relative abundance of an SYNW2391 alkaline phosphatase (phoA), a protein thought to require $\mathrm{Zn}$ as a cofactor, and a SYNW1019 ABC phosphate binding protein (PstS). In the absence of Zn with low $\mathrm{PO}_{4}{ }^{3-}$, these proteins were not as abundant, and the proteome was quite different, suggesting a different $\mathrm{PO}_{4}{ }^{3-}$ response under these conditions. SYNW0359 bacterial metallothionein ( $\mathrm{SmtA}$ ), involved in $\mathrm{Zn}$ handling, showed a similar relative protein abundance response pattern to the alkaline phosphatase and $\mathrm{ABC}$ phosphate binding protein (PstS).

\section{METHODS}

\section{Culturing and protein extraction}

Axenic cultures of Synechococcus sp. WH 8102 obtained from J. Waterbury (Woods Hole Oceanographic Institution) and maintained in a modified PRO-TM media as described in Chapter 3 on pages 75-76. The deplete $\mathrm{Zn}^{2+}$ condition had no $\mathrm{Zn}$ added whereas replete had $\mathrm{Zn}$ added to a total concentration of $10 \mathrm{nM}$, with the free concentrations based on a previous study estimated to be tens of picomolar $\mathrm{Zn}^{2+}$. Low 
$\mathrm{PO}_{4}{ }^{3-}$ cultures had $1 \mu \mathrm{MPO}_{4}{ }^{3-}$ added, whereas high had $65 \mu \mathrm{M} \mathrm{PO}_{4}{ }^{3-}$. Acute $\mathrm{Cd}$ treatments had $\mathrm{Cd}$ added to a total concentration of $10 \mathrm{nM} \mathrm{CdCl}_{2}$, with the free concentration estimated to be $4.4 \mathrm{pM} \mathrm{Cd}^{2+}$ and blanks estimated as described in Chapter 3 on page 76 . Cultures were grown in either $28 \mathrm{~mL}$ polycarbonate tubes or $500 \mathrm{~mL}$ polycarbonate bottles under $30 \mu \mathrm{mol}$ photons ( $\mu$ Einstein) $\mathrm{m}^{-2} \mathrm{~s}^{-1}$ continuous white light. At mid-log phase, the four cultures were split and one of each spiked with $4.4 \mathrm{pM} \mathrm{Cd}^{2+}$. The 8 resulting cultures were harvested 24 hours later (Figure 4.1). Culture growth was monitored by a combination of chlorophyll $a$ and phycoerythrin fluorescence and cell counting by microscopy. All plasticware was cleaned as described in Chapter 3 on page 76. Growth rates were calculated from the natural log of in vivo relative chlorophyll $a$ fluorescence $(n=5)$. For protein samples, approximately $200 \mathrm{~mL}$ of culture were harvested and processed as described in Chapter 3 on pages 76-77.

$1 \mu \mathrm{MPO}_{4}^{3-} \quad 65 \mu \mathrm{M} \mathrm{PO}_{4}^{3-}$

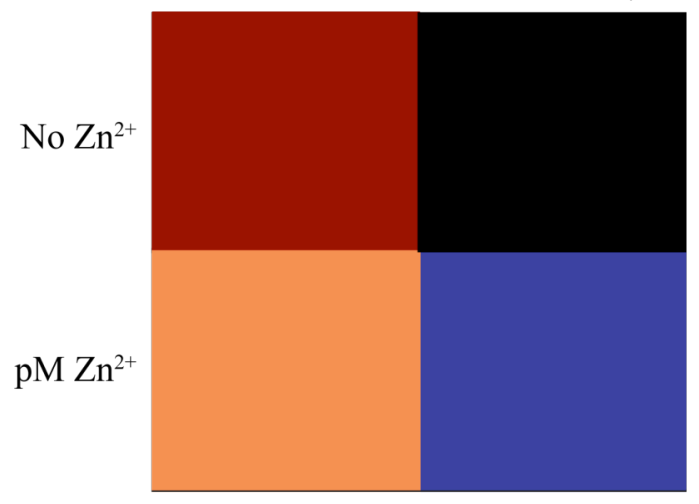

$1 \mu \mathrm{MPO}_{4}^{3-}$

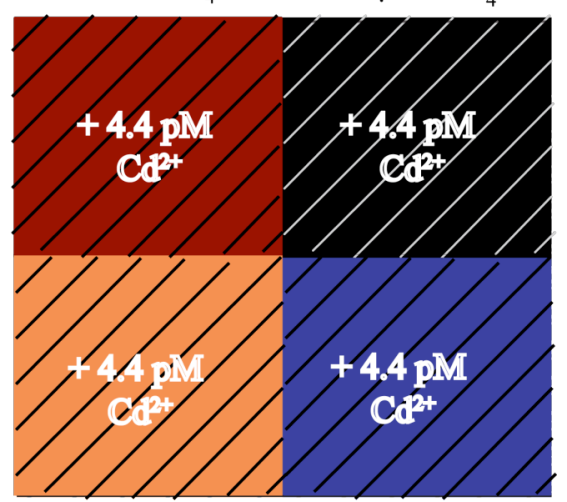

Figure 4.1: Experimental Design. Four experimental treatments with variable $\mathrm{Zn}$ and $\mathrm{PO}_{4}^{3-}$ concentrations ( $\mathrm{No} \mathrm{Zn}^{2+} 65 \mu \mathrm{M} \mathrm{PO}_{4}^{3-}, \mathrm{pM} \mathrm{Zn}^{2+} 65 \mu \mathrm{M} \mathrm{PO}_{4}^{3-}$, No $\mathrm{Zn}^{2+} 1 \mu \mathrm{M} \mathrm{PO}_{4}^{3-}, \mathrm{pM} \mathrm{Zn}^{2+} 1 \mu \mathrm{M} \mathrm{PO}_{4}^{3-}$ ) were grown to mid-log phase, split evenly and $4.4 \mathrm{pM} \mathrm{Cd}^{2+}$ added acutely to one of the splits of each treatment.

\section{Liquid Chromatography-Mass Spectrometry (LC-MS)}

The digests were analyzed by LC-MS using a Paradigm MS4 HPLC system with reverse phase chromatography, Thermo LTQ ion trap mass spectrometer and Microhm ADVANCE source $(2 \mu \mathrm{L} / \mathrm{min}$ flow rate, $345 \mathrm{~min}$ runs, $150 \mathrm{~mm}$ column, $40 \mu \mathrm{L}$ injections, water ACN gradient). Each digest was injected three times for a total of 24 mass spectrometry runs, only two digests from each treatment were analyzed. Mass 
spectra were processed by SEQUEST and PeptideProphet with a fragment tolerance of 1.0 Da (monoisotopic), parent tolerance of $2.0 \mathrm{Da}$ (monoisotopic, fixed modification of +57 on $\mathrm{C}$ (carbamidomethyl), variable modification of +16 on $\mathrm{M}$ (oxidation) and a maximum of 2 missed trypsin cleavages using a database including reversed proteins and common contaminants.

Spectral counts of 16 files were compiled in Scaffold 3 with a peptide false discovery rate of $1.9 \%$, minimum peptide and protein tolerances of 95 and $99 \%$, respectively with a minimum of 2 peptides (Peng et al., 2003; Zhang et al., 2006). A spectral count is the number of times a particular peptide from a protein is sampled during an MS/MS experiment and is indicative of protein relative abundance. Protein functions were assigned by using the Kyoto Encyclopedia of Genes and Genomes (KEGG) unless otherwise noted.

\section{RESULTS}

\section{Physiological Data}

WH8102 was grown under the four variable $\mathrm{Zn}$ and $\mathrm{PO}_{4}{ }^{3-}$ conditions, $\mathrm{Zn}$-high $\mathrm{PO}_{4}{ }^{3-}, \mathrm{Zn}$-low $\mathrm{PO}_{4}{ }^{3-}$, no $\mathrm{Zn}$-high $\mathrm{PO}_{4}{ }^{3-}$, and no $\mathrm{Zn}$-low $\mathrm{PO}_{4}{ }^{3-}$ (Figure 4.1). The response to acute $4.4 \mathrm{pM} \mathrm{Cd}$ stress was monitored by the relative fluorescence of phycoerythrin and chlorophyll $a$ in vivo and by cell counts every other day over the course of the 11 day experiment and four times in the last 24 hours of the experiment (Figures 4.2, 4.3). These growth curves revealed four main observations: 1) the growth rates as calculated up until the $\mathrm{Cd}$ addition were similar (Figure 4.4a), 2) the $\mathrm{Zn}$-high $\mathrm{PO}_{4}{ }^{3-}$ treatment appeared to enter stationary phase (Figures 4.3,4.4b), 3) the low $\mathrm{PO}_{4}{ }^{3-}$ treatments showed increased instantaneous growth rates relative to the high $\mathrm{PO}_{4}{ }^{3-}$ during the final 24 hours of the experiment (Figure 4.4b), and 4) $\mathrm{Cd}$ addition increased instantaneous growth rates further above the low $\mathrm{PO}_{4}{ }^{3-}$ and $\mathrm{Zn}$ treatments (Figure 4.4b). The final cell numbers at harvest were similar for most of the treatments, but showed slightly elevated cell numbers for two treatments, the low $\mathrm{PO}_{4}{ }^{3-}, \mathrm{Cd}$ added both with and without added $\mathrm{Zn}$ (Figure 4.5). 

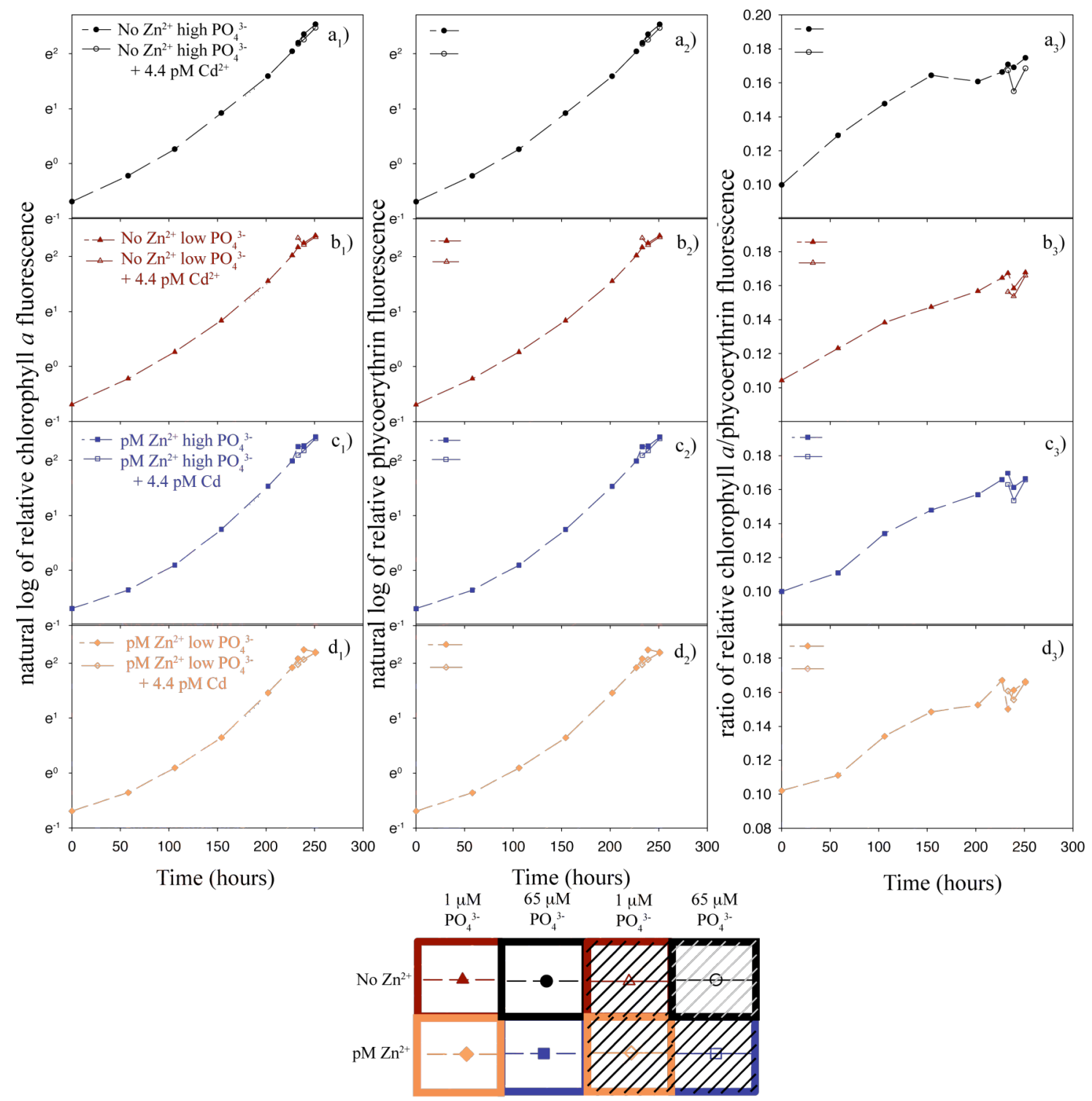

$+\mathrm{Cd}^{2+}$

$\mathrm{Cd}^{2}$

Figure 4.2: Physiological data. The natural $\log$ of relative chlorophyll $a$ fluorescence (Column 1), natural log of phycoerythrin fluorescence (Column 2) and ratio of chlorophyll a/phycoerythrin (Column 3) vs. time for all eight experimental conditions. a) no $\mathrm{Zn}^{2+}$ added $65 \mu \mathrm{M} \mathrm{PO}_{4}{ }^{3-}$ with and without $+4.4 \mathrm{pM} \mathrm{Cd}^{2+}$, b) no $\mathrm{Zn}^{2+}$ added $1 \mu \mathrm{MPO}_{4}{ }^{3-}$ with and without $+4.4 \mathrm{pM} \mathrm{Cd}^{2+}$, c) $\mathrm{Zn}^{2+}$ added $65 \mu \mathrm{M} \mathrm{PO}_{4}{ }^{3-}$ with and without $+4.4 \mathrm{pM} \mathrm{Cd}^{2+}$, d) $\mathrm{Zn}^{2+}$ added $1 \mu \mathrm{M} \mathrm{PO}_{4}{ }^{3-}$ with and without $+4.4 \mathrm{pM} \mathrm{Cd}^{2+}$. Protein samples analyzed and discussed in the text were from the last timepoint depicted. 


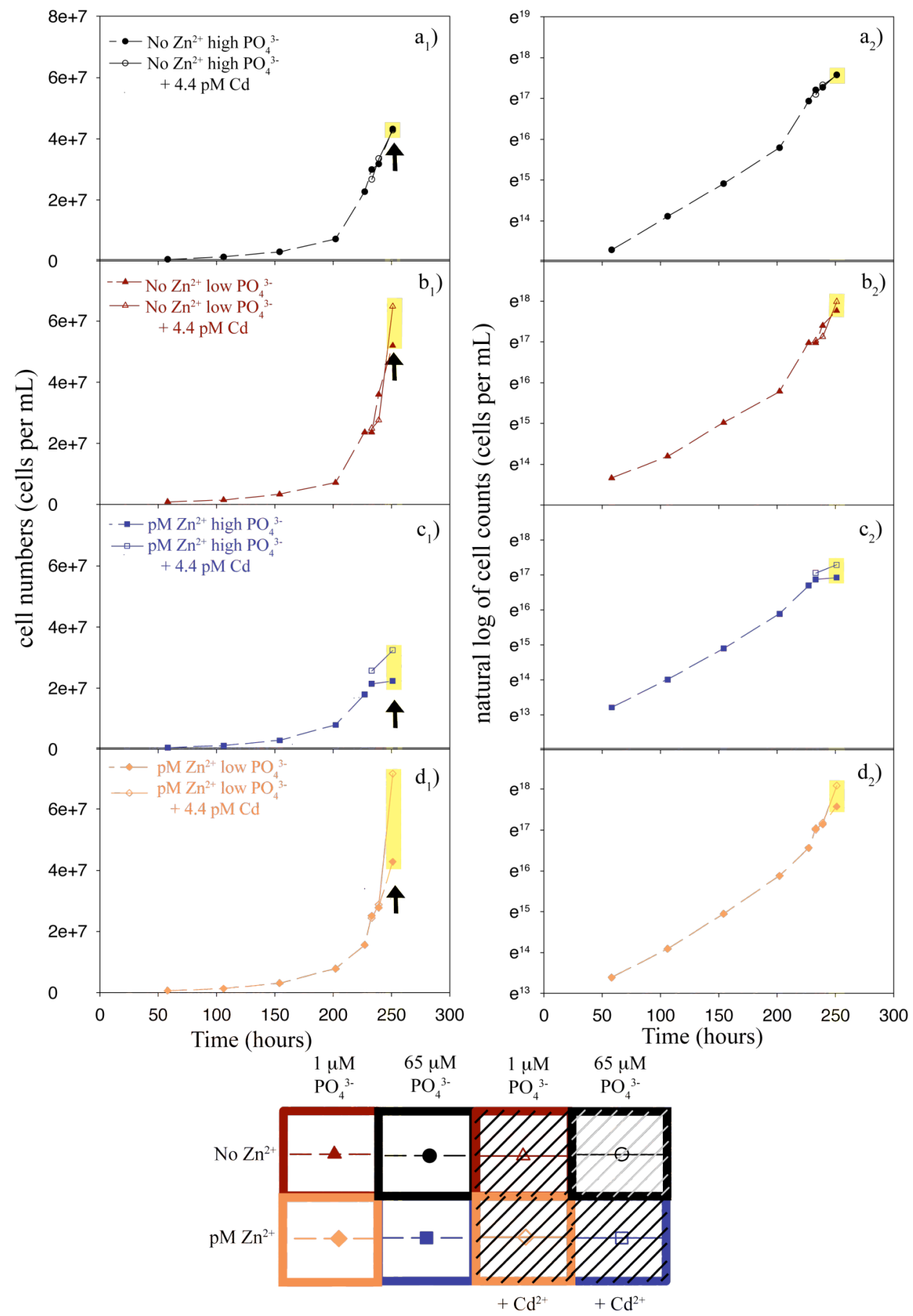

Figure 4.3: Cell numbers (Column 1) and natural log of cell numbers (Column 2) vs. time for all eight experimental conditions. a) no $\mathrm{Zn}^{2+}$ added high $\mathrm{PO}_{4}^{3-}$ with and without $+4.4 \mathrm{pM} \mathrm{Cd}^{2+}$, b) no $\mathrm{Zn}^{2+}$ added low $\mathrm{PO}_{4}^{3-}$ with and without $+4.4 \mathrm{pM} \mathrm{Cd}^{2+}$, c) $\mathrm{Zn}^{2+}$ added high $\mathrm{PO}_{4}^{3-}$ with and without $+4.4 \mathrm{pM} \mathrm{Cd}^{2+}$, d) $\mathrm{Zn}^{2+}$ added low $\mathrm{PO}_{4}^{3-}$ with and without $+4.4 \mathrm{pM} \mathrm{Cd}^{2+}$. Yellow highlights and arrow indicate protein samples analyzed and discussed in the text. Note that phycoerythrin fluorescence in the low $\mathrm{PO}_{4}^{3-}$ treatments appear (Figure 4.2) to level off as cell numbers reveal that cells are still experiencing exponential growth (Figure 4.3). Final cell numbers are higher in low than high phosphate (Figure 4.5). 


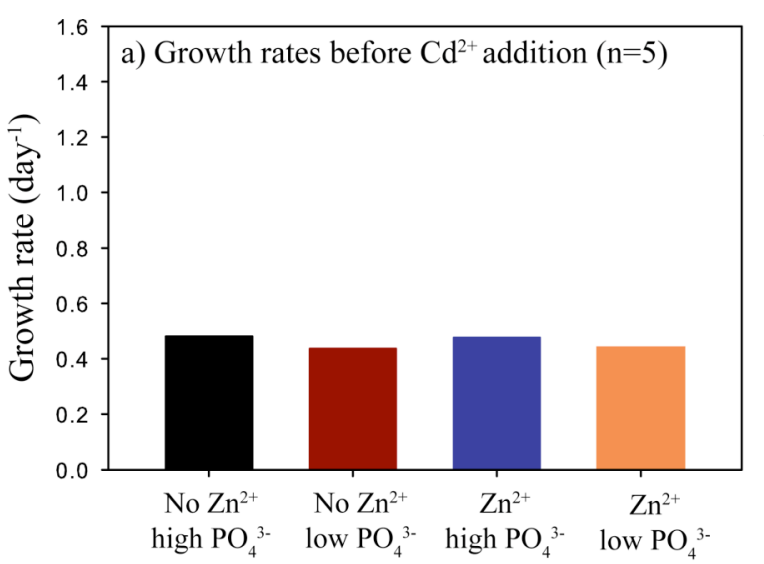

Treatment

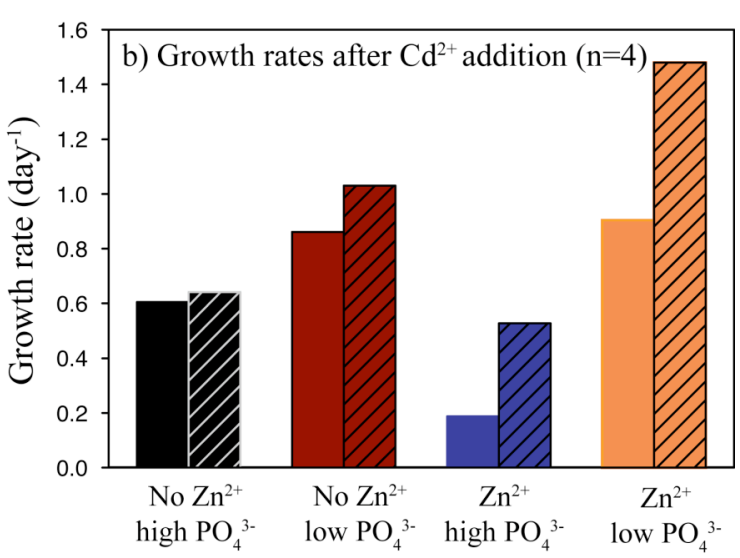

Treatment

Figure 4.4: a) Growth rates. b) Growth rates in the twenty-four hours after cadmium addition until harvest.

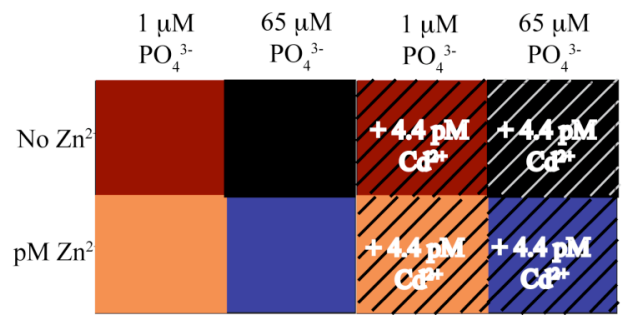

Figure 4.5: Final cell counts at harvest. Error bars represent $10 \%$ of value.

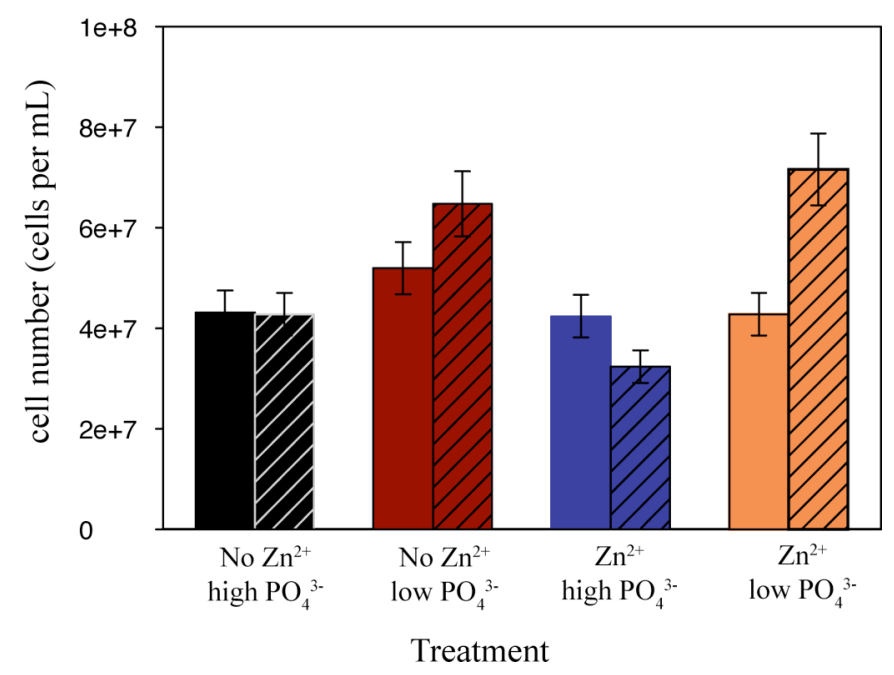


The ratios of chlorophyll $a$ fluorescence per cell, phycoerythrin fluorescence per cell and ratios of relative chlorophyll $a$ fluorescence to phycoerythrin fluorescence per cell showed deviations during the last 31 hours of the experiment (Figure 4.6). The Znhigh $\mathrm{PO}_{4}{ }^{3-}$ treatment had the highest ratio for all three of these ratios. This implies directly that there is more chlorophyll $a$ fluorescence, less phycoerythrin fluorescence, or fewer cells than other treatments or a combination of these factors. Given that the cell abundances in the $\mathrm{Zn}$-high $\mathrm{PO}_{4}{ }^{3-}$ treatment are similar to the $\mathrm{Zn}$-low $\mathrm{PO}_{4}{ }^{3-}$, no $\mathrm{Zn}$-high $\mathrm{PO}_{4}{ }^{3-}$ and no $\mathrm{Zn}$-high $\mathrm{PO}_{4}{ }^{3-}+\mathrm{Cd}$ treatments (Figure 4.5), this implies a difference in the relative fluorescence ratio among these treatments. These similar cell abundances suggest that: 1) the addition of $\mathrm{Cd}$ without $\mathrm{Zn}$ in the medium does not make a difference in the relative chlorophyll $a /$ phycoerythrin ratios per cell, 2) at a constant added $\mathrm{Zn}$ concentration, low $\mathrm{PO}_{4}{ }^{3-}$ causes more of a decrease in the chlorophyll $a$ /phycoerythrin ratio than high $\mathrm{PO}_{4}{ }^{3-}$ and 3) at high $\mathrm{PO}_{4}{ }^{3-}$ the absence of $\mathrm{Zn}$ causes more of a decrease in the chlorophyll a/ phycoerythrin ratio.

Considering treatments with different final cell counts, one notices that in the presence of $\mathrm{Zn}$ at both 1 and $65 \mu \mathrm{M} \mathrm{PO}_{4}{ }^{3-}, \mathrm{Cd}$ causes a greater decrease in chlorophyll $a$ l phycoerythrin fluorescence. This implies that in the presence of $\mathrm{Zn}, \mathrm{Cd}$ causes 1) a decrease in chlorophyll $a, 2$ ) increase in phycoerythrin, 3) increase in number of cells, or 4) a combination of these factors. Figure 4.5 shows an increase in the number of cells in the $\mathrm{Zn}$ treatment with $\mathrm{Cd}$ addition at 1 , but not $65 \mu \mathrm{M} \mathrm{PO}_{4}{ }^{3-}$. 


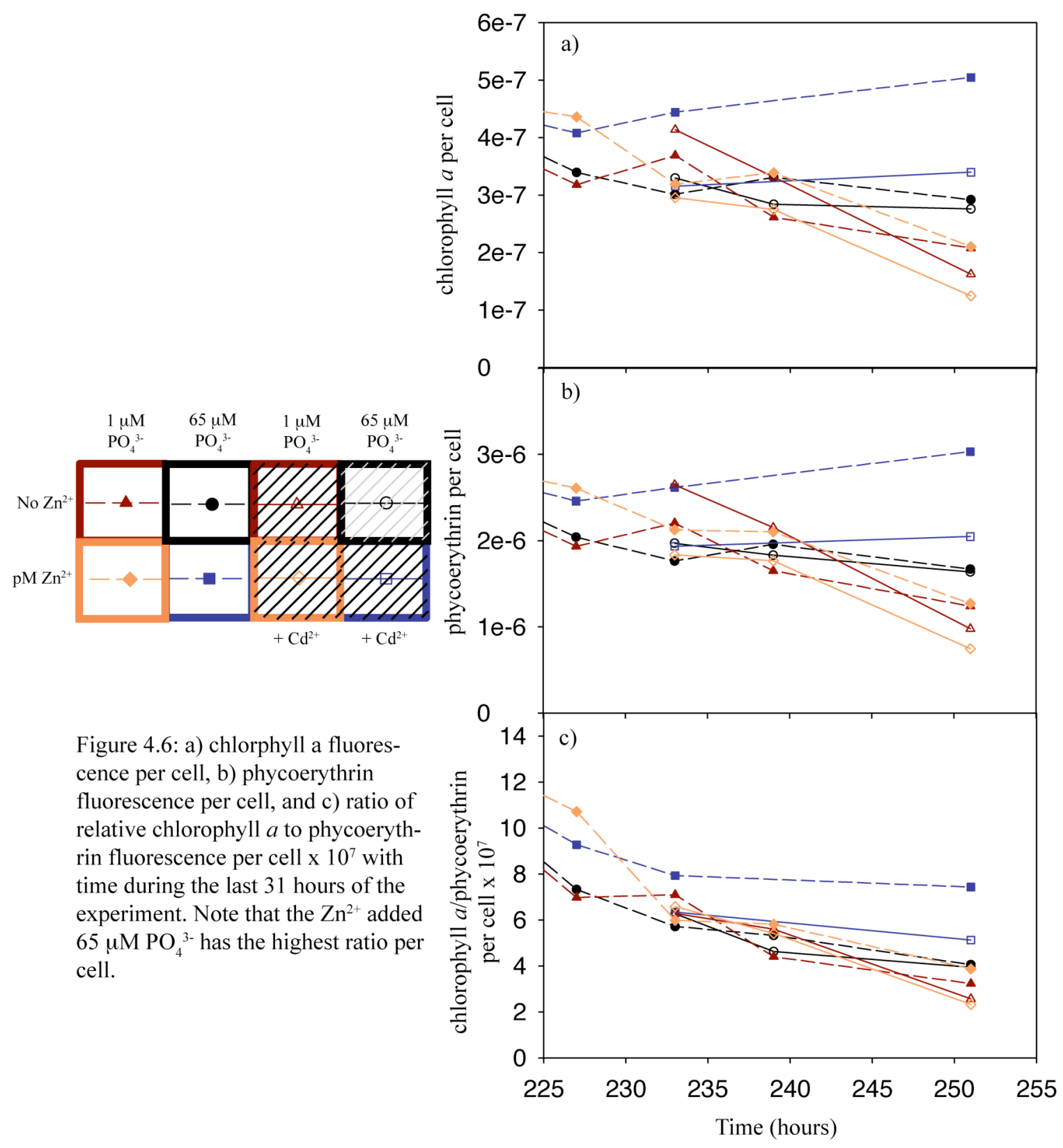




\section{Global Proteomic Data}

Analysis resulted in the identification of 594 proteins from 62,264 mass spectra over 16 injections (8 treatments injected in duplicate). In Scaffold 3, using filters of 95\% peptide minimum confidence level, $99.9 \%$ protein minimum confidence level and a minimum of 2 peptides resulted in a 1.9\% peptide false discovery rate (Peng et al., 2003, Zhang et al., 2006). This experiment identified $23.6 \%$ of the 2519 possible proteins present in the genome of WH8102. Using a more stringent filter, analysis resulted in the identification of 420 proteins from 60,388 mass spectra using $95 \%$ peptide minimum confidence level, 99.9\% minimum confidence level and a minimum of 3 peptides. This resulted in a $0.9 \%$ peptide false discovery rate (Peng et al., 2003, Zhang et al., 2006). Using these more stringent conditions, $16.8 \%$ of the 2519 possible proteins present in the genome of WH8102 were identified. Seventy-one proteins showed differences in protein abundances in at least two treatments using a minimum difference of 7 spectral counts and a threshold of 7 spectral counts, based on technical replicates of each of the 8 treatments. Cluster analysis (Eisen et al., 1998) reveals most prominently phosphatestress effects (Figure 4.7). 


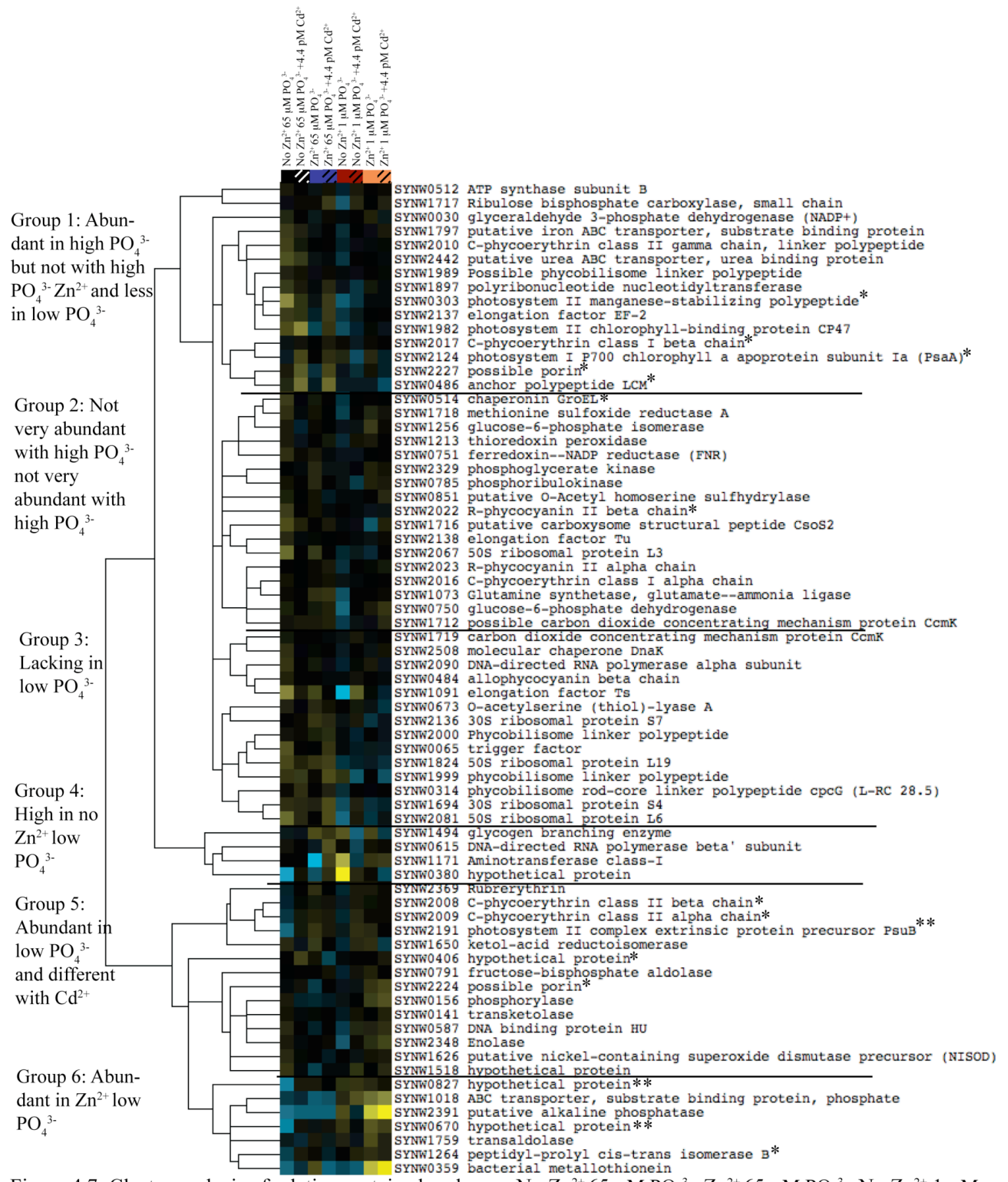

Figure 4.7: Cluster analysis of relative protein abundance. No $\mathrm{Zn}^{2+} 65 \mu \mathrm{M} \mathrm{PO}_{4}^{3-}, \mathrm{Zn}^{2+} 65 \mu \mathrm{M} \mathrm{PO}_{4}^{3-}$, No $\mathrm{Zn}^{2+} 1 \mu \mathrm{M}$ $\mathrm{PO}_{4}^{3-}, \mathrm{Zn}^{2+} 1 \mu \mathrm{M} \mathrm{PO}_{4}^{3-}$ and these four chronic treatments with $4.4 \mathrm{pM} \mathrm{Cd}^{2+}$ acutely added. Four low, $1 \mu \mathrm{M} \mathrm{PO}_{4}{ }^{3-}$ on the right and replete, $65 \mu \mathrm{M} \mathrm{PO}_{4}^{3-}$ on the left. There are 71 proteins. Proteins are averages of duplicates have at least 7 counts and are different by a value of 7 . Data are log transformed, centered, clustered by Kendall's Tau, centroid linkage. Yellow $=$ more abundant, Blue $=$ less abundant, $*=$ statistically different by Fisher's Exact Test between the No $\mathrm{Zn}^{2+} 65 \mu \mathrm{M} \mathrm{PO}_{4}{ }^{3}$ and the $\mathrm{No} \mathrm{Zn}^{2+} 65 \mu \mathrm{M} \mathrm{PO}_{4}{ }^{3}+4.4 \mathrm{pM} \mathrm{Cd}^{2+} * *=$ differentially abundant by two-fold or greater and statistically different by Fisher's Exact Test between the No $\mathrm{Zn}^{2+} 65 \mu \mathrm{M} \mathrm{PO}_{4}^{3}$ and the No $\mathrm{Zn}^{2+} 65 \mu \mathrm{MPO}_{4}^{3}+4.4 \mathrm{pM} \mathrm{Cd}^{2+}$. 
Pairwise analyses between experimental treatments reveal most noticeably the effects of $\mathrm{PO}_{4}{ }^{3-}$ stress, but also lesser $\mathrm{Cd}$ and $\mathrm{Zn}$ effects (Figure 4.8). There are 28 ways to pair 8 treatments, only 12 are considered here, querying what happens to the proteome when two conditions are held constant and the third is varied. Among the 16 pairwise comparisons not discussed here, one could query, for example, if $\mathrm{Cd}$ could replace $\mathrm{Zn}$ at low $\mathrm{PO}_{4}{ }^{3-}$ (compare no $\mathrm{Zn}$-low $\mathrm{PO}_{4}{ }^{3-}$ to no $\mathrm{Zn}$-low $\mathrm{PO}_{4}{ }^{3-}+\mathrm{Cd}$ ). Proteins are considered differentially abundant here if the average spectral count value of one of the pairs is equal to or greater than five and the pair of proteins are different by two-fold or more. Use of Fisher's Exact Test (Zhang et al., 2006) confirms that most proteins are different in abundance using these stringencies, excepting a few proteins with five spectral counts. The two-fold or more differentially abundant proteins with low spectral counts remain in the tables, but are considered tenuous in analysis. The results of Fisher's Exact Test also conclude that more proteins are statistically different in abundance than the $\geq$ two-fold analysis alone. This is because a smaller fold difference in a greater value is statistically different, thus proteins with higher spectral counts that are different by less than two-fold are differentially abundant (Compare Tables 4.4 and 4.5).

In these pairwise proteome comparisons, three observations can be made: 1) the no $\mathrm{Zn}$-low $\mathrm{PO}_{4}{ }^{3-}$ treatment had the greatest number of proteins $\geq$ two-fold different in abundance (Compare Figure 4.8a, b and c), 2) Cd addition caused a greater change in the number of $\geq$ two-fold different in abundance in the absence of $\mathrm{Zn}$ (Figure 4.8b), and 3) the acute addition of $\mathrm{Cd}$ under both low and high $\mathrm{PO}_{4}{ }^{3-}$ conditions had fewer proteins of $\geq$ two-fold different in abundance in the presence or absence of $\mathrm{Zn}$ (Figure 4.8c). The combination of no $\mathrm{Zn}$-low $\mathrm{PO}_{4}{ }^{3-}$ (red) had the greatest number of proteins (55 in Figure 4.8a, 32 in Figure 4.8b and 31 in Figure 4.8c) differentially abundant compared to any other treatment. For comparison, the no $\mathrm{Zn}$-high $\mathrm{PO}_{4}{ }^{3-}$ treatment had the number of proteins different as 55 in Figure 4.8a, 10 in Figure 4.8b and 16 in Figure 4.8c. The presence of $\mathrm{Zn}$ caused a smaller change in the total number of proteins $\geq$ two-fold different in abundance when Cd was added acutely (compare 42 with no added $\mathrm{Zn}$, both high and low $\mathrm{PO}_{4}{ }^{3-}$ to 11 proteins in the presence of $\mathrm{Zn}$, both high and low $\mathrm{PO}_{4}{ }^{3-}$; Figure 
4.8b). Cadmium addition under low and high $\mathrm{PO}_{4}{ }^{3-}$ conditions caused fewer proteins to be differentially abundant in the presence or absence of $\mathrm{Zn}$, perhaps hinting that $\mathrm{Cd}$ alleviates $\mathrm{Zn}$ deprivation (Figure 4.8c).

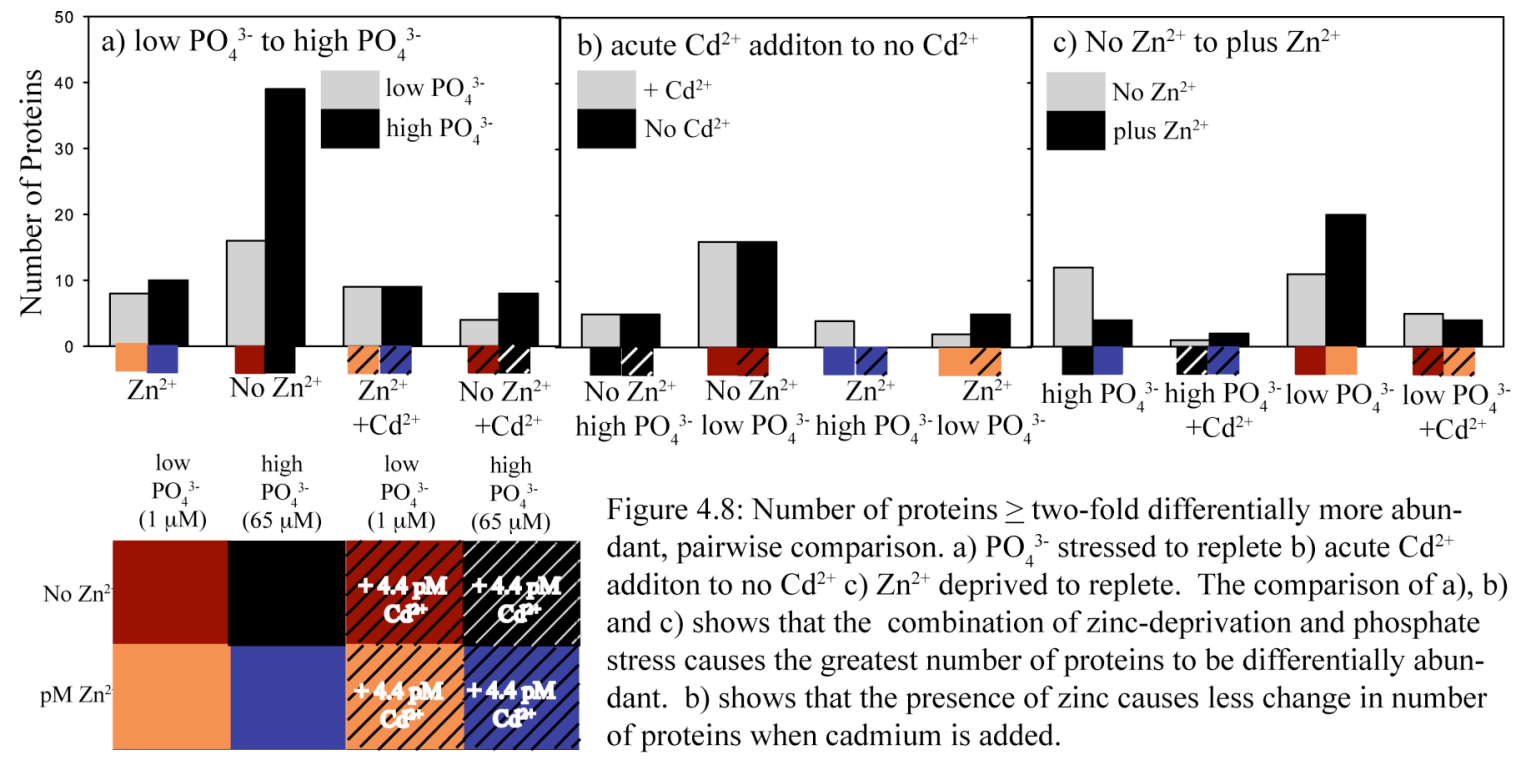

\section{The influence of phosphate (pairwise comparisons)}

As noted by cluster analysis in Figure 4.7 and the number of proteins differentially abundant in Figure 4.8, $\mathrm{PO}_{4}{ }^{3-}$ appeared to cause the most difference in this multivariate $\mathrm{Cd}-\mathrm{Zn}-\mathrm{PO}_{4}{ }^{3-}$ matrix experiment. In the $\mathrm{Zn}$ added, 1 compared to $65 \mu \mathrm{M}$ $\mathrm{PO}_{4}{ }^{3-}$ treatments, 18 proteins were two-fold or more differentially abundant with a spectral count of at least five (Table 4.1). Eight proteins were more abundant in the $1 \mu \mathrm{M}$ $\mathrm{PO}_{4}{ }^{3-}$ treatment, including 6 proteins also found to be differentially expressed as transcripts in a microarray experiment by Tetu et al. (2009) (starred in Table 4.1). These 6 proteins are SYNW2391 putative alkaline phosphatase, SYNW1018 ABC transporter, substrate binding protein, phosphate (PstS), SYNW0953 cell-surface protein required for swimming motility (SwmB), SYNW0085 cell-surface protein required for swimming motility (SwmA), SYNW0700 glyceraldehyde-3-phosphate dehydrogenase and SYNW224 possible porin. Also of note is SYNW0359 bacterial metallothionein. See Figure 4.9 for relative abundances of SYNW0359, SYNW2391 and SYNW1018. Ten proteins were more abundant in the $65 \mu \mathrm{M} \mathrm{PO}_{4}{ }^{3-}$ treatments, including 6 ribosomal proteins one of which was found to be downregulated as a transcript in the Tetu et al. 
(2009) analysis, SYNW2082 50S ribosomal protein L18.

Table 4.1: WH8102 proteins that are two-fold or greater differentially abundant in the $\mathrm{Zn}^{2+} 1 \mu_{M} \mathrm{PO}_{4}^{3-}($ low $\mathrm{PO}_{4}^{3-}$ ) vs. $\mathrm{Zn}^{2+} 65 \mu \mathrm{M} \mathrm{PO}_{4}^{3-}\left(\right.$ high $\mathrm{PO}_{4}^{3-}$ ).

\begin{tabular}{|c|c|c|c|c|c|}
\hline $\begin{array}{l}\text { SYNW } \\
\text { ID }\end{array}$ & Function & Protein & $\begin{array}{l}\mu \mathrm{MPO}_{4}^{3-} 6 \\
\text { counts }\end{array}$ & $\begin{array}{l}65 \mu \mathrm{M} \mathrm{PO}_{4}^{3-} \\
\text { counts } \\
\end{array}$ & $\begin{array}{l}\mathrm{Zn}^{2+} 65 \mu \mathrm{M} \mathrm{PO}{ }^{3-} \\
\text { fold change }\end{array}$ \\
\hline $2391 *$ & $\mathrm{U}, \mathrm{P}$ & putative alkaline phosphatase & $8.1 \pm 0.8$ & $1.0 \pm 0.0$ & +8.1 \\
\hline $1018^{*}$ & $\mathrm{ABC}, \mathrm{P}$ & $\begin{array}{l}\text { ABC transporter, substrate-binding protein, } \\
\text { phosphate (PstS) }\end{array}$ & $76.9 \pm 1.3$ & $19.2 \pm 2.4$ & +4.0 \\
\hline 1661 & ukn & hypothetical protein & $5.2 \pm 2.1$ & $1.4 \pm 0.7$ & +3.7 \\
\hline $0953 *$ & Mo & $\begin{array}{l}\text { cell-surface protein required for swimming } \\
\text { motility (swmB) }\end{array}$ & $5.2 \pm 0.6$ & $1.4 \pm 0.7$ & +3.7 \\
\hline 0359 & $\mathrm{U}, \mathrm{Zn}$ & bacterial metallothionein (SmtA) & $7.1 \pm 3.2$ & $3.3 \pm 0.6$ & +2.2 \\
\hline $0085^{*}$ & Mo & $\begin{array}{l}\text { cell-surface protein required for swimming } \\
\text { motility (swmA) }\end{array}$ & $9.0 \pm 0.8$ & $4.2+0.6$ & +2.1 \\
\hline 0799* & $\mathrm{M}, \mathrm{E}, \mathrm{C}$ & $\begin{array}{l}\text { glyceraldehyde-3-phosphate dehydrogenase } \\
\text { (gap3) }\end{array}$ & $2.4 \pm 0.6$ & $0.5 \pm 0.7$ & +4.7 \\
\hline $2224 *$ & $\mathrm{U}, \mathrm{Om}$ & possible porin (som) & $61.2 \pm 1.7$ & $29.4 \pm 2.6$ & +2.1 \\
\hline 1773 & $\mathrm{M}, \mathrm{Nu}, \mathrm{Pu}, \mathrm{A}$ & adenylosuccinate synthetase (purA, adeK) & $1.4 \pm 0.7$ & $7.5 \pm 0.1$ & -5.2 \\
\hline 0814 & $\mathrm{M}, \mathrm{Nu}, \mathrm{Pu}$ & adenine phosphoribosyltransferase & $1.0 \pm 0.0$ & $5.1 \pm 0.8$ & -5.1 \\
\hline 2500 & $\mathrm{M}, \mathrm{Cb}, \mathrm{TCA}$ & & & & \\
\hline & E,C & aconitate hydratase $(\mathrm{acnB})$ & $2.8 \pm 0.0$ & $7.5 \pm 0.1$ & -2.6 \\
\hline 2069 & GI,T & 50S ribosomal protein L23 (rpl23,rplW) & $3.8 \pm 1.3$ & $8.9 \pm 0.5$ & -2.3 \\
\hline 2068 & GI,T & 50S ribosomal protein L4 (rpl4,rplD) & $4.3 \pm 2.1$ & $9.3 \pm 0.2$ & -2.2 \\
\hline 2079 & GI,T & 50S ribosomal protein L5 (rpl5,rplE) & $5.2 \pm 1.9$ & $10.7 \pm 0.4$ & -2.1 \\
\hline 1716 & $\mathrm{C}$ & $\begin{array}{l}\text { putative carboxysome structural peptide } \\
\qquad(\mathrm{CsoS} 2)\end{array}$ & $6.6 \pm 0.1$ & $13.1 \pm 1.6$ & -2.0 \\
\hline 2136 & GI,T & 30S ribosomal protein S7 (rps7,rpsG) & $8.1 \pm 0.5$ & $15.9 \pm 1.0$ & -2.0 \\
\hline 2083 & GI,T & 30S ribosomal protein S5 (rps5,rpsE) & $5.2 \pm 0.8$ & $10.3 \pm 0.2$ & -2.0 \\
\hline $2082 * *$ & GI,T & 50S ribosomal protein L18 (rpl18,rplR) & $3.3 \pm 0.6$ & $6.5 \pm 2.5$ & -2.0 \\
\hline
\end{tabular}

Arranged in highest to lowest fold change $\mathrm{Zn}$-low $\mathrm{PO}_{4}{ }^{3-}\left(1 \mu \mathrm{M} \mathrm{PO}_{4}{ }^{3-}\right)$ then $\mathrm{Zn}$-high $\mathrm{PO}_{4}{ }^{3-}\left(65 \mu \mathrm{M} \mathrm{PO}_{4}{ }^{3-}\right)$. $+=$ fold greater than $\mathrm{Zn}$-high $\mathrm{PO}_{4}^{3-}$, - = fold less than $\mathrm{Zn}$-high $\mathrm{PO}_{4}^{3-}, *=$ Corresponding transcript identitfied in Tetu et al. 2009 as strongly upregulated under early P-stress $\left(5 \mu \mathrm{M} \mathrm{PO}_{4}^{3-}\right)$, ** = Corresponding transcript identitfied in Tetu et al. 2009 as strongly downregulated under early P-stress $\left(5 \mu \mathrm{M} \mathrm{PO}_{4}{ }^{3-}\right)$.

$\mathrm{U}=$ unclassified, $\mathrm{P}=$ phosphorus metabolism, $\mathrm{ABC}=\mathrm{ABC}$ transporter, ukn $=$ unknown, $\mathrm{Mo}=$ motility, $\mathrm{Zn}=$ zinc metabolism, $\mathrm{M}=$ metabolism, $\mathrm{E}=$ energy metabolism, $\mathrm{C}=$ carbon fixation, $\mathrm{Om}=$ outer membrane protein, $\mathrm{Nu}=$ nucleic acid metabolism, $\mathrm{Pu}=$ purine metabolism, $\mathrm{A}=$ amino acid metabolism, $\mathrm{Cb}=$ carbohydrate metabolism, $\mathrm{TCA}=$ citrate cycle, $\mathrm{GI}=$ genetic information processing, $\mathrm{T}=$ translation. 


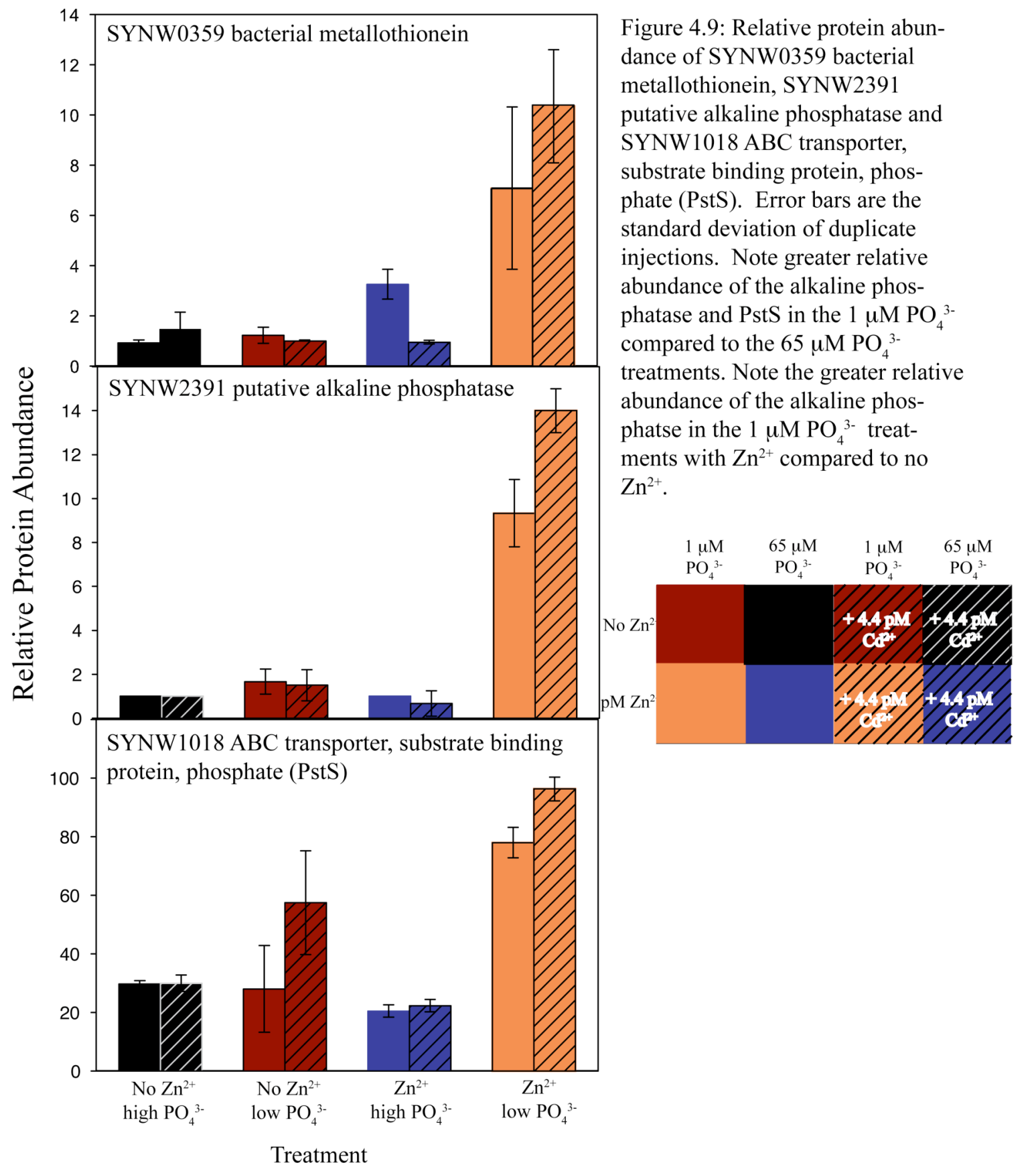

Seven proteins were strongly upregulated transcripts in the Tetu et al., 2009 microarray experiment that were not two-fold or greater differentially abundant in this experiment (Table 4.2). One of these was close, however: SYNW0156 phosphorylase, 1.9-fold greater in the $1 \mu \mathrm{M} \mathrm{PO}_{4}{ }^{3-}$ treatment. 
Table 4.2: WH8102 proteins that are strongly upregulated ( $\geq$ two-fold) under early P-stress according to transcript analysis in Tetu et al. 2009, but not $\geq$ two-fold more abundant according to our global proteomic analysis, $1 \mu \mathrm{M} \mathrm{PO}_{4}^{3-} \mathrm{Zn}^{2+}\left(\right.$ low $\mathrm{PO}_{4}^{3-}$ ) than the $65 \mu \mathrm{MPO}_{4}^{3-} \mathrm{Zn}^{2+}\left(\right.$ high $\mathrm{PO}_{4}^{3-}$ ).

\begin{tabular}{|c|c|c|c|c|c|}
\hline $\begin{array}{l}\text { SYNW } \\
\text { ID }\end{array}$ & Function & Protein & $\begin{array}{c}\mathrm{Zn}^{2+} \\
\mathrm{M} \mathrm{PO}_{4}^{3-} \\
\text { counts }\end{array}$ & $\begin{array}{c}\mathrm{Zn}^{2+} \\
65 \mathrm{MM} \mathrm{PO}_{4}^{3} \\
\text { counts } \\
\end{array}$ & $\begin{array}{c}\mathrm{Zn}^{2+} 1 \mu \mathrm{MPO} \mathrm{PO}^{3-} \\
\mathrm{Zn}^{2+} 65 \mu \mathrm{MO}_{4}^{3} \\
\text { fold change }\end{array}$ \\
\hline 1815 & $\mathrm{ABC}, \mathrm{P}$ & $\begin{array}{l}\text { ABC transporter, substrate binding } \\
\text { protein, phosphate (PstS) }\end{array}$ & $5.2 \pm 0.8$ & $6.6 \pm 1.4$ & -1.3 \\
\hline 0156 & $\mathrm{M}, \mathrm{Ss}$ & phosphorylase & $36 . \overline{6} \pm 5.3$ & $20.0 \pm 4.9$ & +1.9 \\
\hline 0406 & Ukn & hypothetical protein & $13.8 \pm 2.2$ & $14.9 \pm 1.0$ & -1.1 \\
\hline 1119 & $\mathrm{M}, \mathrm{Pt}, \mathrm{G}$ & 6-phosphogluconate dehydrogenase & $6.6 \pm 0.1$ & $4.1 \pm 1.2$ & +1.6 \\
\hline 1213 & U,GI & thioredoxin peroxidase & $34.6 \pm 0.1$ & $30.8 \pm 1.9$ & +1.1 \\
\hline 2508 & GI & $\begin{array}{l}\text { molecular chaperone DnaK2, heat shock } \\
\text { protein hsp70-2 }\end{array}$ & $19.4 \pm 1.7$ & $23.4 \pm 0.5$ & -1.2 \\
\hline 0160 & Ukn & conserved hypothetical protein & $7.6 \pm 1.2$ & $4.7 \pm 0.1$ & +1.6 \\
\hline
\end{tabular}

$\mathrm{ABC}=\mathrm{ABC}$ transporter, $\mathrm{P}=$ phosphate metabolism, $\mathrm{M}=$ metabolism, $\mathrm{Ss}=$ sugar and starch metabolism, $\mathrm{Ukn}$

$=$ unknown, $\mathrm{Pt}=$ pentose phosphate pathway, $\mathrm{G}=$ glutathione metabolism, $\mathrm{U}=$ unclassified, $\mathrm{G} \mathrm{I}=$ genetic information prrocessing

In the no $\mathrm{Zn}-1 \mu \mathrm{M} \mathrm{PO}_{4}{ }^{3-}$ compared to no $\mathrm{Zn}-65 \mu \mathrm{M} \mathrm{PO}_{4}{ }^{3-}, 55$ proteins were twofold or more differentially abundant with a spectral count of at least five (Table 4.3). Sixteen proteins were more abundant in the $1 \mathrm{PO}_{4}{ }^{3-}$ treatment, including five hypothetical proteins and two proteins involved in photosynthesis. No proteins showed abundances similar to gene expression in Tetu et al., 2009. Thirty-nine proteins were more abundant in the $65 \mu \mathrm{M} \mathrm{PO}_{4}{ }^{3-}$ treatments, including 12 involved in genetic information processing, two involved in the biosynthesis of chlorophyll and two hypothetical proteins. 
Table 4.3: WH8102 proteins that are two-fold or more differentially abundant in the no $\mathrm{Zn}^{2+} 1 \mu \mathrm{M}^{\mathrm{PO}}{ }_{4}^{3-}$ vs. no $\mathrm{Zn}^{2+} 65 \mathrm{\mu MPO}_{4}{ }^{3}$.

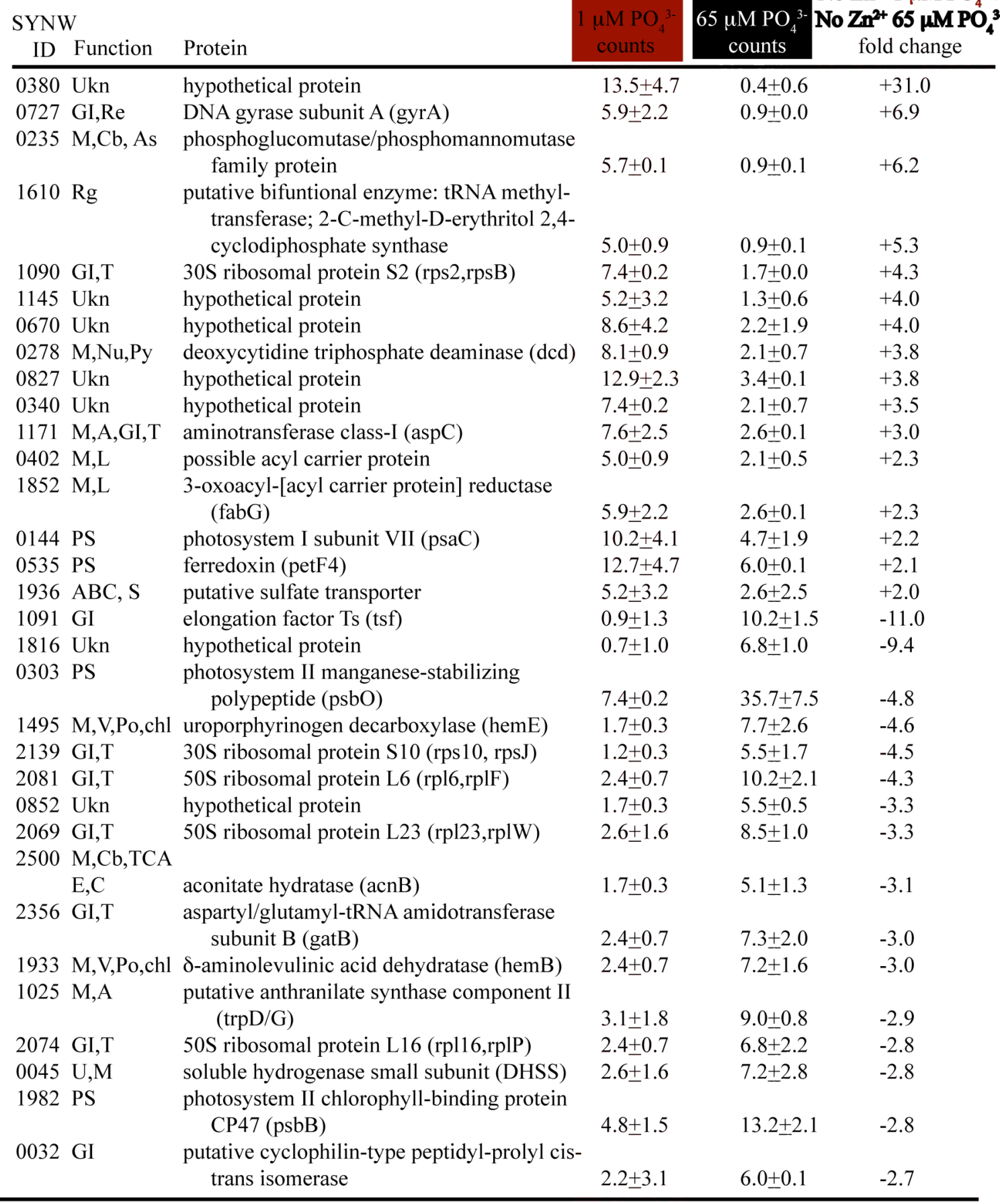


Table 4.3 (continued, page 2 of 2 ):

\begin{tabular}{|c|c|c|c|c|c|}
\hline $\begin{array}{l}\text { SYNW } \\
\text { ID }\end{array}$ & Function & Protein & 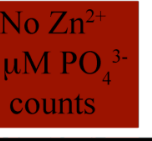 & $\begin{array}{c}\mathrm{No}_{\mathrm{Zn}^{2+}} \\
65 \mu \mathrm{M} \mathrm{PO}_{4}^{3-} \\
\text { counts }\end{array}$ & $\begin{array}{c}\text { No } \mathrm{Zn}^{2+} 1 \mu \mathrm{M} \mathrm{PO}_{4}^{3-} / \\
\text { No } \mathrm{Zn}^{2+} 65 \mu \mathbf{M P O}_{4}^{3-} \\
\text { fold change }\end{array}$ \\
\hline 0033 & GI,T & elongation factor $\mathrm{P}$ (efp) & $2.4 \pm 0.7$ & $6.4 \pm 2.8$ & -2.7 \\
\hline 0750 & $\mathrm{M}, \mathrm{Cb}, \mathrm{G}$ & glucose-6-phosphate dehydrogenase (zwf) & $4.0 \pm 0.4$ & $10.7 \pm 2.1$ & -2.6 \\
\hline 0462 & $\mathrm{Ei}, \mathrm{Si}$ & nitrogen regulatory protein $\mathrm{P}-\mathrm{II}(\mathrm{g} \ln \mathrm{B})$ & $2.6 \pm 1.6$ & $6.8 \pm 1.0$ & -2.6 \\
\hline 0819 & M,A & dihydrodipicolinate reductase (dapB) & $2.7 \pm 2.4$ & $6.8 \pm 1.0$ & -2.5 \\
\hline 2067 & GI,T & 50S ribosomal protein L3 (rpl3,rplC) & $4.9 \pm 5.5$ & $12.0 \pm 3.9$ & -2.5 \\
\hline 2082 & GI,T & 50S ribosomal protein L18 (rpl18,rplR) & $3.1 \pm 1.8$ & $7.7 \pm 0.2$ & -2.5 \\
\hline 2442 & $\mathrm{ABC}, \mathrm{Si}$ & $\begin{array}{l}\text { putative urea } \mathrm{ABC} \text { transporter, urea binding } \\
\text { protein (urtA1) }\end{array}$ & $24.1 \pm 5.0$ & $55.9 \pm 4.5$ & -2.3 \\
\hline 1815 & $\mathrm{ABC}, \mathrm{P}$ & $\begin{array}{l}\text { ABC transporter, substrate binding protein, } \\
\text { phosphate (PstS) }\end{array}$ & $4.0 \pm 0.4$ & $9.4 \pm 1.0$ & -2.3 \\
\hline 1694 & GI,T & $30 \mathrm{~S}$ ribosomal protein $\mathrm{S} 4$ (rps4,prsD) & $4.1 \pm 4.4$ & $9.4 \pm 0.2$ & -2.3 \\
\hline 2348 & $\mathrm{M}, \mathrm{Cb}, \mathrm{E}, \mathrm{GI}$ & enolase (eno) & $7.0 \pm 4.5$ & $15.7 \pm 2.6$ & -2.3 \\
\hline 1824 & GI,T & 50S ribosomal protein L19 (rpl19) & $6.6 \pm 1.2$ & $14.5 \pm 0.4$ & -2.2 \\
\hline 0687 & $\mathrm{M}, \mathrm{Nu}, \mathrm{Py}$ & putative thioredoxin reductase & $2.4 \pm 0.7$ & $5.1 \pm 1.3$ & -2.1 \\
\hline 2246 & $\mathrm{Ei}$ & two-component response regulator (rpaB) & $5.7 \pm 0.1$ & $11.9 \pm 2.1$ & -2.1 \\
\hline 2137 & GI,T & elongation factor EF-2 (fusA) & $12.1 \pm 1.3$ & $25.1 \pm 1.2$ & -2.1 \\
\hline 1835 & PS & $\begin{array}{l}\text { photosystem I reaction center subunit III } \\
\text { (PsaF) }\end{array}$ & $3.3 \pm 0.6$ & $6.9 \pm 2.6$ & -2.1 \\
\hline 1718 & $\mathrm{C}$ & $\begin{array}{l}\text { ribulose bisphosphate carboxylase, large chain } \\
\text { (rbcL,cbbL) }\end{array}$ & $38.2 \pm 11.7$ & $78.7 \pm 9.4$ & -2.1 \\
\hline 0405 & $\mathrm{M}, \mathrm{Nu}, \mathrm{Pu}, \mathrm{A}$ & fumarate lyase: adenylosuccinate lyase (purB) & $3.1 \pm 1.8$ & $6.4 \pm 0.8$ & -2.1 \\
\hline 1617 & GI,T & 30S ribosomal protein $\mathrm{S} 16$ (rps16,rpsP) & $4.8 \pm 1.5$ & $9.8 \pm 2.1$ & -2.1 \\
\hline 2487 & $\mathrm{ABC}, \mathrm{Ei}$ & putative cyanate $\mathrm{ABC}$ transporter & $5.5 \pm 2.5$ & $11.1 \pm 2.7$ & -2.0 \\
\hline 0514 & GI,F & chaperonin (GroEL) & $55.8 \pm 15.5$ & $112.0 \pm 0.1$ & -2.0 \\
\hline \multirow{3}{*}{$\begin{array}{l}2068 \\
1073\end{array}$} & U,GI,T & $\begin{array}{l}\text { DNA-directed RNA polymerase beta subunit } \\
\text { (rpoB) }\end{array}$ & $4.0 \pm 0.4$ & $8.1 \pm 1.6$ & -2.0 \\
\hline & $\begin{array}{l}\text { GI,T } \\
\text { M,E,N,A }\end{array}$ & $\begin{array}{l}\text { 50S ribosomal protein } \mathrm{L} 4 \text { (rpl4,rplD) } \\
\text { glutamine synthetase, glutamate--ammonia }\end{array}$ & $5.6 \pm 6.5$ & $11.1 \pm 1.5$ & -2.0 \\
\hline & & ligase $(\mathrm{g} \ln \mathrm{A})$ & $20.0 \pm 4.5$ & $39.6 \pm 1.6$ & -2.0 \\
\hline
\end{tabular}

Arranged in highest to lowest fold change $\mathrm{Zn}$-high $\mathrm{PO}_{4}^{3-}$, than $\mathrm{Zn}-$ low $\mathrm{PO}_{4}{ }^{3-} .+=$ fold greater thanZn-high $\mathrm{PO}_{4}^{3-},-=$ fold less than $\mathrm{Zn}$-high $\mathrm{PO}_{4}^{3-}$. Ukn = unknown, $\mathrm{GI}=$ genetic information processing, $\mathrm{Re}=\mathrm{DNA}$ replication and repair, $\mathrm{M}=$ metabolism, $\mathrm{Cb}=$ carbohydrate metabolism, $\mathrm{As}=$ amino sugar metabolism, $\mathrm{Rg}=$ regulatory function, $\mathrm{T}$ $=$ translation, $\mathrm{Nu}=$ nucleic acid metabolism, $\mathrm{Py}=$ pyrimidine metabolism, $\mathrm{A}=$ amino acid metabolism, $\mathrm{L}=$ lipid metabolism, $\mathrm{PS}=$ photosynthesis, $\mathrm{ABC}=\mathrm{ABC}$ transporter, $\mathrm{S}=$ sulfur metabolism, $\mathrm{V}=$ vitamin metabolism, $\mathrm{Po}=$ porphryin metabolism, chl = chlorophyll metabolism, TCA = citrate cycle, $\mathrm{E}=$ energy metabolism, $\mathrm{C}=$ carbon fixation, $\mathrm{G}=$ glutathione metabolism, $\mathrm{Ei}=$ environmental information processing, $\mathrm{Si}=$ signalling, $\mathrm{P}=$ phosphorus metabolism, $\mathrm{F}=$ protein folding, $\mathrm{Pu}=$ purine biosynthesis, $\mathrm{N}=$ nitrogen metabolism

In the $\mathrm{Zn}+4.4 \mathrm{pM} \mathrm{Cd}{ }^{2+}$, low compared to high $\mathrm{PO}_{4}{ }^{3-}$ treatments, 17 proteins were two-fold or more differentially abundant with a spectral count of at least five (Table III.1). Nine proteins were more abundant in the $\mathrm{Zn}$-low $\mathrm{PO}_{4}{ }^{3-}+\mathrm{Cd}$ treatment, including five proteins also found to be differentially expressed as genes in a microarray experiment by Tetu et al., 2009 (starred in Table III.1). These five proteins are 
SYNW2391 putative alkaline phosphatase, SYNW1018 ABC transporter, substrate binding protein, phosphate (PstS), SYNW0953 cell-surface protein required for swimming motility (SwmB), and SYNW0156 phosphorylase. Eight proteins were more abundant in the $\mathrm{Zn}$-high $\mathrm{PO}_{4}{ }^{3-}+\mathrm{Cd}$ treatment, including three related to the phycobilisomes and two ribosomal proteins.

In the no $\mathrm{Zn}+4.4 \mathrm{pM} \mathrm{Cd}^{2+}$, low compared to high $\mathrm{PO}_{4}{ }^{3-}$ treatments, 12 proteins were two-fold or more differentially abundant with a spectral count of at least five (Table III.2). Four proteins were more abundant in the no $\mathrm{Zn}-$ low $\mathrm{PO}_{4}{ }^{3-}+4.4 \mathrm{pM} \mathrm{Cd}^{2+}$ treatment, including two proteins also found to be differentially expressed as genes in a microarray experiment by Tetu et al., 2009. These two proteins are SYNW0953 cellsurface protein required for swimming motility (SwmB) and SYNW1018 ABC transporter, substrate binding protein, phosphate (PstS). Eight proteins were more abundant in the no $\mathrm{Zn}$-high $\mathrm{PO}_{4}{ }^{3-}+4.4 \mathrm{pM} \mathrm{Cd}^{2+}$ treatment, including six involved in photosynthesis (two phycobilisome, three Photosystem II and one Photosystem I proteins).

\section{The influence of cadmium (pairwise comparisons)}

$\mathrm{Cd}$ effects can be discerned by examining pair-wise protein comparisons (Figure 4.8b). In the no $\mathrm{Zn}$-high $\mathrm{PO}_{4}{ }^{3-}+4.4 \mathrm{pM} \mathrm{Cd}^{2+}$ compared to no $\mathrm{Cd}$ added treatments, 10 proteins were two-fold or more differentially abundant with a spectral count of at least five (Table 4.4). Five proteins were more abundant in the no $\mathrm{Zn}-$ high $\mathrm{PO}_{4}{ }^{3-}+4.4 \mathrm{pM}$ $\mathrm{Cd}^{2+}$ treatment, including three unknown proteins, one involved in photosystem II and one involved in the biosynthesis of riboflavin (Vitamin B2) (Figure 4.10). Five proteins were more abundant in the no $\mathrm{Zn}$-high $\mathrm{PO}_{4}{ }^{3-}$ no added $\mathrm{Cd}^{2+}$ treatment (Figure 4.11). 
Table 4.4:WH8102 proteins that are $\geq$ two-fold differentially abundant in the no $\mathrm{Zn}^{2+} 65 \mu \mathrm{M} \mathrm{PO}_{4}^{3-}+4.4 \mathrm{pM}$ $\mathrm{Cd}^{2+}$ vs. the no $\mathrm{Zn}^{2+} 65 \mu \mathrm{MPO}_{4}^{3-}$.

\begin{tabular}{|c|c|c|c|c|c|c|}
\hline $\begin{array}{l}\text { SYNW } \\
\text { ID }\end{array}$ & Function & Protein & 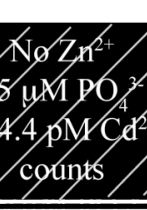 & $\begin{array}{c}\text { No } \mathrm{Zn}^{2+} \\
65 \mu \mathrm{MO}_{4}^{3-} \\
\text { counts }\end{array}$ & $\begin{array}{c}65 \mu \mathrm{MOO}_{4}^{3-} \\
+4.4 \mathrm{pM} \mathrm{Cd}^{3+} \\
\mathrm{No} \mathrm{Zn}^{2+} \\
65 \mu \mathrm{PO}_{4}^{3-} \\
\text { fold change } \\
\end{array}$ & $\begin{array}{c}\text { Fisher Test } \\
\text { P-value } \\
\end{array}$ \\
\hline 0908 & Ukn & hypothetical protein & $6.2 \pm 0.5$ & $1.3+0.6$ & +4.9 & $95 \%(0.01)$ \\
\hline 0670 & Ukn & hypothe & 7. & 1.9 & +3.3 & $5 \%(0.0048)$ \\
\hline 0827 & Ukn & hypothetical protein & $11.0+2.4$ & $3.4+0.1$ & +3.2 & $95 \%(0.0016)$ \\
\hline 2191 & PS & $\begin{array}{l}\text { photosytem II complex } \\
\text { extrinsic protein }\end{array}$ & & & & \\
\hline \multirow[b]{2}{*}{0082} & \multirow[b]{2}{*}{$\mathrm{M}, \mathrm{V}, \mathrm{R}$} & precursor (psuB) & $13.8+0.2$ & $5.5+1.7$ & +2.5 & $95 \%(0.0016)$ \\
\hline & & $\begin{array}{l}\text { riboflavin synthase subunit } \\
\text { beta (ribH) }\end{array}$ & $8.6+2.4$ & $4.3+0.1$ & +2.0 & $95 \%(0.047)$ \\
\hline 1118 & $\mathrm{M}, \mathrm{Cb}$ & $\begin{array}{l}\text { glucose-1-phosphate } \\
\text { adenylyltransferase }\end{array}$ & & & & \\
\hline \multirow[t]{2}{*}{0405} & $\mathrm{M}, \mathrm{Nu}, \mathrm{Pu}, \mathrm{A}$ & $\begin{array}{l}(\mathrm{agp}, \mathrm{glgC}) \\
\text { fumarate lyase: adenylo- }\end{array}$ & $1.5+0.7$ & $5.5+0.5$ & -3.6 & $95 \%(0.019)$ \\
\hline & & & $1.9+0.1$ & $6.4+0.8$ & -3.4 & $95 \%(0.041)$ \\
\hline 2139 & GI,T & $\begin{array}{l}\text { 30S ribosomal protein } \mathrm{S} 10 \\
(\mathrm{rps} 10, \mathrm{rps} \mathrm{J})\end{array}$ & $1.9+0.1$ & 5.5 & -2 . & \\
\hline \multirow{3}{*}{$\begin{array}{l}1953 \\
2500\end{array}$} & $\mathrm{Ukn}, \mathrm{L}$ & putative glycerol kinase & $2.4+2.1$ & $5.6+2.0$ & -2.3 & $0 \%(0.15)$ \\
\hline & $\mathrm{M}, \mathrm{Cb}, \mathrm{TCA}$ & & & & & \\
\hline & $\mathrm{E}, \mathrm{C}$ & aconitate hydratase (acnB) & $2.4+0.7$ & $5.1+1.3$ & -2.1 & $0 \%(0.21)$ \\
\hline
\end{tabular}

Arranged in highest to lowest fold change $4.4 \mathrm{pM} \mathrm{Cd}^{2+}$ vs. control (no $\mathrm{Zn}$ and no added $\mathrm{Cd}$ ). $+=$ fold greater than control, - = fold less than control, Ukn = unknown, PS = photosynthesis, $\mathrm{M}=$ metabolism, $\mathrm{V}=$ vitamin metabolism, $\mathrm{R}=$ riboflavin metabolsim, $\mathrm{Cb}=$ carbohydrate metabolism, $\mathrm{Nu}=$ nucleic acid metabolism, $\mathrm{Pu}=$ purine metabolism, $\mathrm{A}=$ amino acid metabolism, $\mathrm{GI}=$ genentic information processing, $\mathrm{T}=$ translation, $\mathrm{L}=$ lipid metabolism, $\mathrm{TCA}=$ citrate cycle, $\mathrm{E}=$ energy metabolism, $\mathrm{C}=$ carbon fixation, in this case reductive glyoxylate cycle.

In addition to proteins being considered differentially abundant by a two-fold or greater differential abundance, there is Fisher's Exact Test as explained earlier in this section. Applying Fisher's Exact Test results in 13 more proteins being labeled significantly differential in abundance, in addition to the 7 in Table 3.1 (Table 4.5). Ten proteins are statistically more abundant in the no $\mathrm{Zn}-65 \mu \mathrm{M} \mathrm{PO}_{4}{ }^{3-}+4.4 \mathrm{pM} \mathrm{Cd}^{2+}$, of which five are involved in photosynthesis (Figure 4.10). Three are statistically more abundant in the no $\mathrm{Zn}-65 \mu \mathrm{M} \mathrm{PO}_{4}{ }^{3-}$ no added $\mathrm{Cd}^{2+}$ (Figure 4.11). Seven of these 13 are involved in photosynthesis. 
Table 4.5: Additional WH8102 proteins that are differentially abundant in the acute no $\mathrm{Zn}^{2+} 65 \mu \mathrm{MPO}_{4}^{3-}+4.4 \mathrm{pM}$

$\mathrm{Cd}^{2+}$ vs. the no $\mathrm{Zn}^{2+} 65 \mu \mathrm{M} \mathrm{PO}_{4}^{3-}$ according to Fisher's Exact Test.

ID Function Protein

0486 PS anchor polypeptide $\mathrm{L}_{\mathrm{CM}}(\mathrm{apcE})$

0406 Ukn hypothetical protein

2022 PS

$2224 \mathrm{U}, \mathrm{Om}$

2124 PS

0303 PS

R-phycocyanin II beta chain (rpcB)

possible porin (som)

photosystem I P700 chlorophyll $a$

$$
\text { apoprotein subunit Ia (psaA) }
$$

photosystem II manganese-stabilizing polypeptide (psbO)

$2227 \mathrm{U}, \mathrm{Om}$ possible porin (som)

0514 GI,F chaperonin GroEL (groEL)

$1264 \mathrm{U}, \mathrm{F}$

2017

PS

peptidyl-prolyl cis-trans isomerase B

C-phycoerythrin class I beta chain

$$
\text { (cpeB) }
$$

2369 U,Fo rubrerythrin

2008 PS C-phycoerythrin class II beta chain (mpeB)
-phycoerythrin class II alpha chain

2009 PS (mpeA)

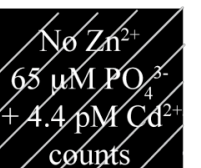

counts

$16+2.5$

$20+1.3$

$91+9.3$

$51+12.4$

$15+1.2$

$20.1+0.6$

$31+7.7$

$77+1.1$

$18+2.8$

$74.0+0.3$
$57+5.6$

$410+6.5$

$346+25$
No $\mathrm{Zn}^{2+}$ $65 \mu \mathrm{M} \mathrm{PO}_{4}^{3-}$ $+4.4 \mathrm{pM} \mathrm{Cd}^{2+1}$ No $\mathrm{Zn}^{2+}$ $65 \mu \mathrm{M} \mathrm{PO}_{4}{ }^{3-} \quad$ Fisher Test fold change P-value

\section{No $\mathrm{Zn}^{2}$ \\ $65 \mathrm{MM} \mathrm{PO}_{4}$}

counts

$10+2.1$

$13+4.6$

$121.8+0.7$

$+1.6$

$95 \%(0.035)$

$42+2.3$

$+1.5$

$95 \%(0.034)$

$95 \%(0.032)$

$+1.2$

$95 \%(0.025)$

$8+2.0$

$+1.8$

$95 \%(0.01)$

$35.7+7.5$

$21+4.8$

$-1.7$

$+1.4$

$95 \%(0.0094)$

$112.0+0.1$

$-1.4$

$95 \%(0.0090)$

$9.4+0.2$

$+1.9$

$95 \%(0.0067)$

$59+5.1$

$43+2.9$

$+1.2$

$95 \%(0.0032)$

$+1.3$

$95 \%(0.0031)$

$296+19$

$+1.2$

$95 \%(1.5 \mathrm{E}-17)$

$210+23$

$+1.7$

$95 \%(1.4 \mathrm{E}-25)$

Arranged in order of decreasing P-value. $+=$ fold greater than control, $-=$ fold less than control, PS = photosynthesis, Ukn $=$ unknown, $\mathrm{U}=$ unclassified, $\mathrm{Om}=$ outer membrane protein, $\mathrm{GI}=$ genentic information processing, $\mathrm{F}=$ folding, $\mathrm{Fo}=$ possible ferroxidase activity 


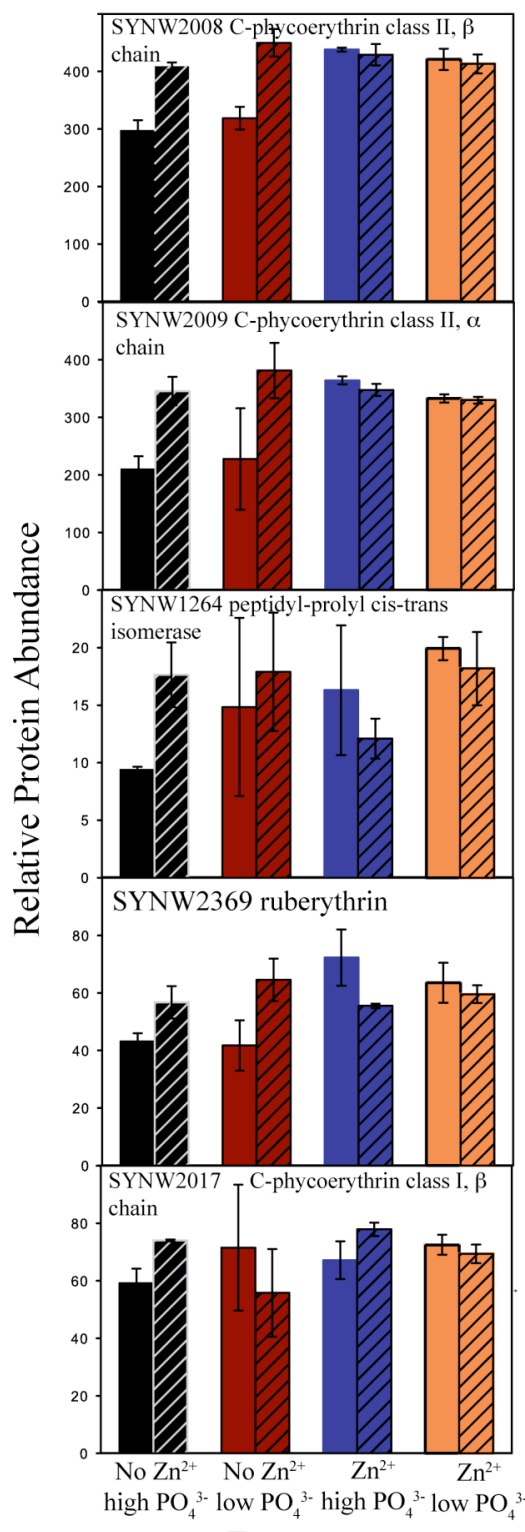

Treatment

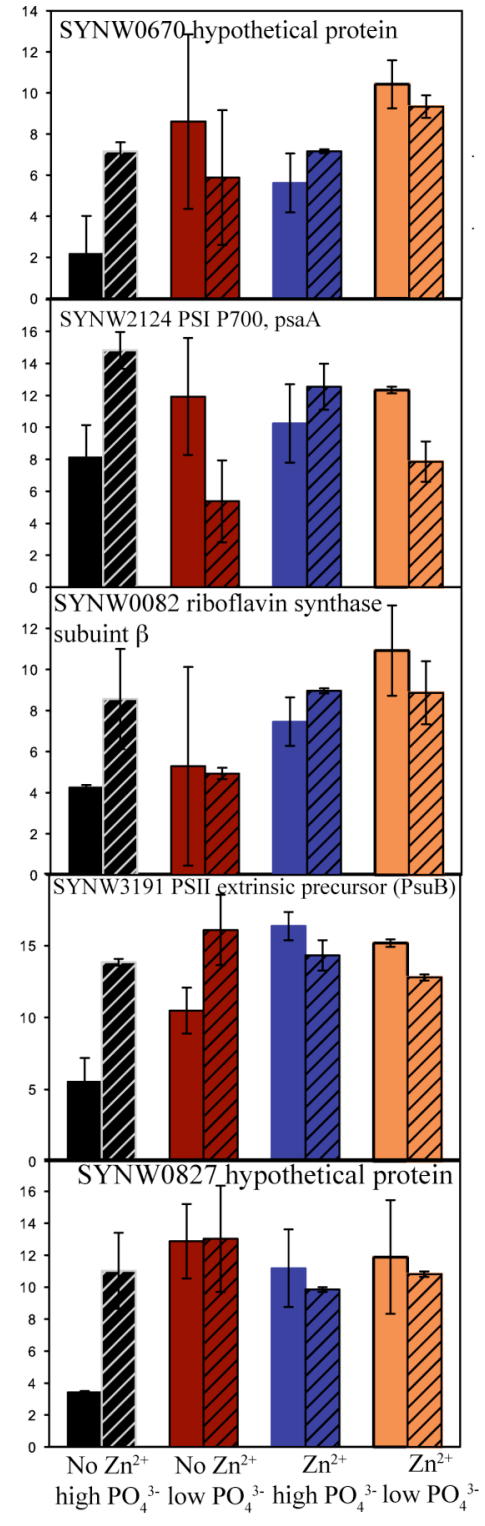

Treatment

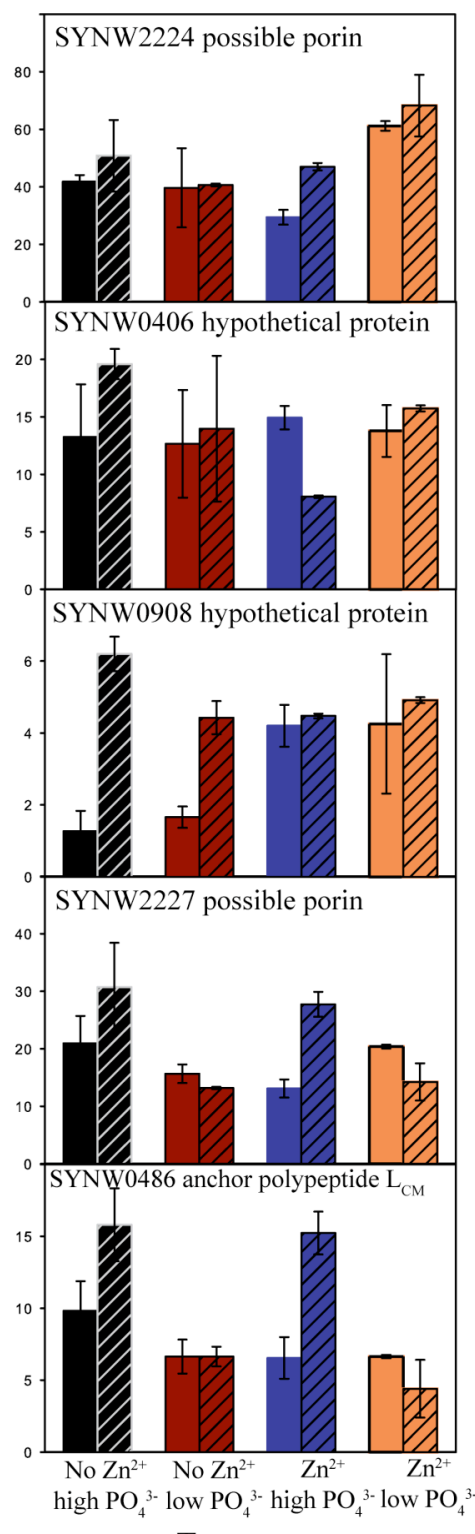

Treatment

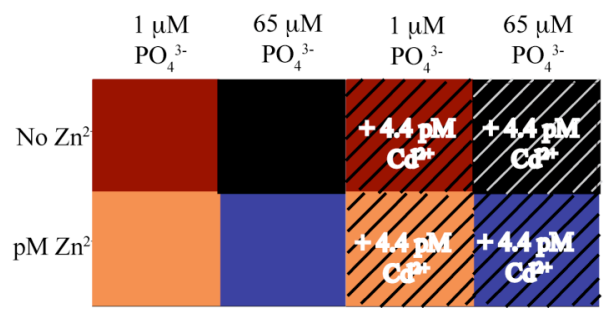

Figure 4.10: Relative protein abundance of proteins $\geq$ two-fold greater in abundance and/or statistically different by Fisher's Exact Test in the no $\mathrm{Zn}^{2+}$ added $65 \mu \mathrm{M} \mathrm{PO}_{4}^{3-}+$ $4.4 \mathrm{pM} \mathrm{Cd}^{2+}$ compared to the no $\mathrm{Zn}^{2+}$ added $65 \mu \mathrm{M} \mathrm{PO}_{4}{ }^{3-}$ treatments. Error bars are the standard deviation of duplicate injections. 


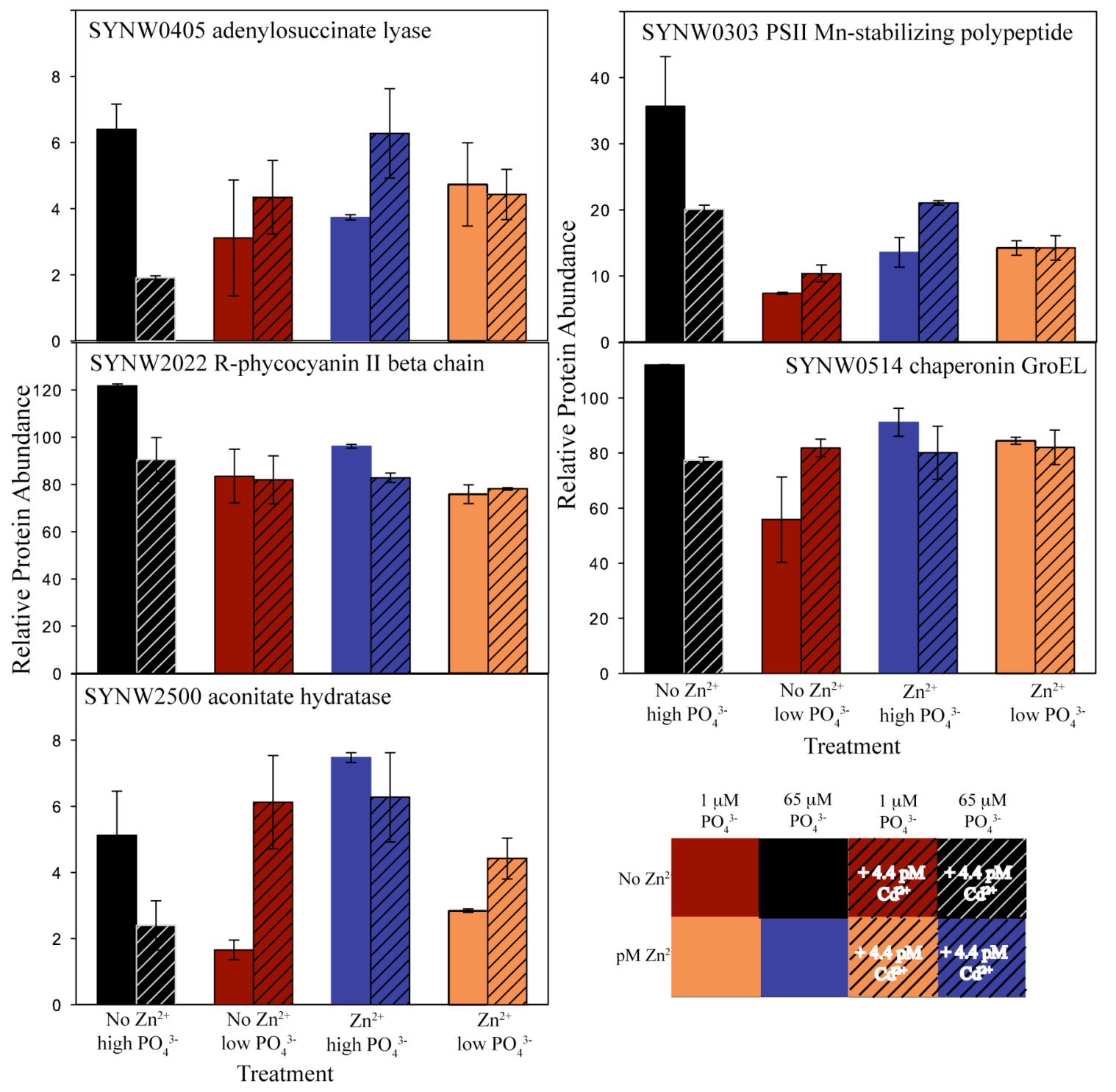

Figure 4.11: Relative protein abundance of proteins more than two-fold less abundant and/or statistically different by Fisher's Exact Test in the no $\mathrm{Zn}^{2+}$ added $65 \mu \mathrm{M} \mathrm{PO}_{4}^{3-}+4.4 \mathrm{pM} \mathrm{Cd}^{2+}$ compared to the no $\mathrm{Zn}^{2+}$ added 65 $\mu \mathrm{M} \mathrm{PO}_{4}{ }^{3-}$ treatments. Error bars are the standard deviation of duplicate injections.

In the $\mathrm{Zn}$-high $\mathrm{PO}_{4}{ }^{3-}+4.4 \mathrm{pM} \mathrm{Cd}^{2+}$ compared to no $\mathrm{Cd}^{2+}$ added treatments, four proteins were two-fold or more differentially abundant with a spectral count of at least five (Table III.3). All four proteins were more abundant in the $\mathrm{Zn}$-high $\mathrm{PO}_{4}{ }^{3-}+4.4 \mathrm{pM}$ $\mathrm{Cd}^{2+}$ treatment, three of the four are involved in photosynthesis and one SYNW2227 possible porin, unknown function, probably outer membrane protein.

In the no $\mathrm{Zn}$-low $\mathrm{PO}_{4}{ }^{3-}+4.4 \mathrm{pM} \mathrm{Cd}^{2+}$ compared to no $\mathrm{Cd}^{2+}$ added treatments, 32 
proteins were two-fold or more differentially abundant with a spectral count of at least five (Table III.4). Sixteen proteins were more abundant in the no $\mathrm{Zn}-1$ low $\mathrm{PO}_{4}{ }^{3-}+4.4 \mathrm{pM}$ $\mathrm{Cd}^{2+}$ treatment, including three ribosomal proteins, a protein involved in chlorophyll biosynthesis and one protein involved in photosynthesis. Sixteen proteins were more abundant in the no $\mathrm{Zn}$-low $\mathrm{PO}_{4}{ }^{3-}$ no added $\mathrm{Cd}^{2+}$ treatment, including three hypothetical proteins, a protein involved in chlorophyll biosynthesis and two proteins involved in photosynthesis.

In the $\mathrm{Zn}$-low $\mathrm{PO}_{4}{ }^{3-}+4.4 \mathrm{pM} \mathrm{Cd}^{2+}$ compared to no $\mathrm{Cd}^{2+}$ added treatments, seven proteins were two-fold or more differentially abundant with a spectral count of at least five (Table III.5). Two proteins were more abundant in the $\mathrm{Zn}-\mathrm{low} \mathrm{PO}_{4}{ }^{3-}+4.4 \mathrm{pM} \mathrm{Cd}^{2+}$ treatment, SYNW1933 $\delta$-aminolevulinic acid dehydratase, which is in the biosynthetic pathway for chlorophyll and SYNW1716 putative carboxysome structural peptide (CsoS2), presumably useful for carbon fixation. Five proteins were more abundant in the $\mathrm{Zn}$-low $\mathrm{PO}_{4}{ }^{3-}$ no added $\mathrm{Cd}^{2+}$ treatment, including one hypothetical protein, a protein involved in lipid metabolism, a protein involved in purine metabolism, a protein involved in carbohydrate metabolism and a protein involved in amino acid metabolism.

\section{The influence of zinc (pairwise comparisons)}

$\mathrm{Zn}$ effects can be discerned by examining pair-wise protein comparisons (Figure 4.8). In the high $\mathrm{PO}_{4}{ }^{3-}$ treatments comparing no $\mathrm{Zn}$ to $\mathrm{Zn}$ added (Figure 4.1 - black to blue), 16 proteins were two-fold or more differentially abundant with a spectral count of at least five (Table III.6). Twelve proteins were more abundant in the no $\mathrm{Zn}$-high $\mathrm{PO}_{4}{ }^{3-}$ treatment, including three proteins involved in photosynthesis (SYNW0303 photosystem II manganese-stabilizing polypeptide, SYNW1982 photosystem II chlorophyll-binding protein CP47 and SYNW1835 photosystem I reaction center subunit III (PsaF)), two hypothetical proteins, SYNW1933 $\delta$-aminolevulinic acid dehydratase involved in chlorophyll biosynthesis and SYNW0085 cell surface protein required for swimming motility (SwmA). Four proteins were more abundant in the $\mathrm{Zn}$-high $\mathrm{PO}_{4}{ }^{3-}$ treatment, including SYNW0670 hypothetical protein, SYNW2191 photosystem II complex extrinsic protein precursor (PsuB) and SYNW2310 glutaredoxin. 
In low $\mathrm{PO}_{4}{ }^{3-}$ treatments comparing no $\mathrm{Zn}$ to $\mathrm{Zn}$ added (Figure 4.1 - red to orange), 31 proteins were two-fold or more differentially abundant with a spectral count of at least five (Table III.7). Eleven proteins were more abundant in the no $\mathrm{Zn}-\mathrm{low} \mathrm{PO}_{4}{ }^{3-}$ treatment, including three hypothetical proteins, two ribosomal proteins, and one protein involved in photosynthesis. Twenty proteins were more abundant in the $\mathrm{Zn}$-low $\mathrm{PO}_{4}{ }^{3-}$ treatment, including SYNW0259 bacterial metallothionein, SYNW2391 putative alkaline phosphatase, SYNW0953 cell surface protein required for swimming mobility (SwmB), three hypothetical proteins (SYNW0128, SYNW0160 and SYNW1661), one protein involved in chlorophyll biosynthesis, SYNW1065 putative photosystem II reaction center (psb28), SYNW1717 ribulose bisphosphate carboxylase small chain and SYNW0082 riboflavin (Vitamin B2) synthase subunit beta.

In the high $\mathrm{PO}_{4}{ }^{3-}+$ acute $4.4 \mathrm{pM} \mathrm{Cd}^{2+}$ comparing no $\mathrm{Zn}$ to $\mathrm{Zn}$ added (Figure 4.1 black/hatched to blue/hatched), three proteins were two-fold or more differentially abundant with a spectral count of at least five (Table III.8). One protein was more abundant in the no $\mathrm{Zn}$-high $\mathrm{PO}_{4}{ }^{3-}+4.4 \mathrm{pM} \mathrm{Cd}^{2+}$ treatment, SYNW0406 hypothetical protein. Two proteins were more abundant in the $\mathrm{Zn}$-high $\mathrm{PO}_{4}{ }^{3-}+4.4 \mathrm{pM} \mathrm{Cd}^{2+}$ treatment, SYNW0405 adenylosuccinate lyase, involved in purine and amino acid metabolism and SYNW2500 aconitate hydratase, involved in carbohydrate metabolism, TCA cycle, glyoxylate and dicarboxylate metabolism and energy metabolism, reductive carboxylate cycle.

In the low $\mathrm{PO}_{4}{ }^{3-}+$ acute $4.4 \mathrm{pM} \mathrm{Cd}^{2+}$ comparing no $\mathrm{Zn}$ to $\mathrm{Zn}$ added (Figure 4.1 $\mathrm{red} /$ hatched to orange/hatched), 9 proteins were two-fold or more differentially abundant with a spectral count of at least five (Table III.9). Five proteins were more abundant in the no $\mathrm{Zn}$-low $\mathrm{PO}_{4}{ }^{3-}+4.4 \mathrm{pM} \mathrm{Cd}^{2+}$ treatment, including SYNW1815 ABC transporter, substrate binding protein, phosphate. Four proteins were more abundant in the Zn-low $\mathrm{PO}_{4}{ }^{3-}+4.4 \mathrm{pM} \mathrm{Cd}^{2+}$ treatment, including SYNW0359 bacterial metallothionein and SYNW2391 putative alkaline phosphatase (Figure 4.9).

\section{Cadmium-zinc interactions at high phosphate (pairwise comparison)}

This pairwise comparison is not part of the 12 pairwise comparisons. It queries if 
the relative protein abundances look similar if $\mathrm{Cd}$ is present instead of $\mathrm{Zn}$ at high $\mathrm{PO}_{4}{ }^{3-}$ (Figure 4.1 - black/hatched to blue). In the no $\mathrm{Zn}-$ high $\mathrm{PO}_{4}{ }^{3-}+4.4 \mathrm{pM} \mathrm{Cd}^{2+}$ compared to $\mathrm{Zn}$-high $\mathrm{PO}_{4}{ }^{3-}$ treatments, 8 proteins were two-fold or more differentially abundant with a spectral count of at least five (Table III.10). Seven proteins were more abundant in the no $\mathrm{Zn}$-high $\mathrm{PO}_{4}{ }^{3-}+4.4 \mathrm{pM} \mathrm{Cd}^{2+}$, including four proteins involved in photosynthesis, SYNW0085 cell surface protein required for swimming motility (SwmA) and SYNW2227 possible porin, unknown function, outer membrane associated. SYNW2500 aconitate hydratase, involved in carbohydrate metabolism, TCA cycle, glyoxylate and dicarboxylate metabolism and energy metabolism, reductive carboxylate cycle was more abundant in the $\mathrm{Zn}$-high $\mathrm{PO}_{4}{ }^{3-}$ treatment.

\section{DISCUSSION}

Phosphate stress and limitation in Synechococcus WH8102 has been much studied in recent years by many different methods, including computational prediction ( $\mathrm{Su}$ et al., 2003; Su et al., 2007), physiological experimentation (Moore et al., 2005), and microarray analyses (Tetu et al., 2009, Ostrowski et al., 2010). Phosphate stress and limitation has also been studied in Prochlorococcus by microarray (Martiny et al., 2006). PCR-based field assays of picocyanobacteial phnD, phosphonate-binding protein of ABC-type phosphonate transporter (SYNW1169) showed a depth-dependent pattern of expression which followed gradients of P-availability (Ilikchyan et al., 2009) and the phnD from the cyanobacterium, Trichodesmium erythraeum, was found to be differentially expressed in field populations in the North Atlantic (Dyhrman et al., 2006). Previous experiments revealed an interaction between the addition of $\mathrm{Cd}$ and the greater relative abundance of phosphate stress proteins (Cox et al., unpublished data) and this interaction was further explored in this study. Because of the role of $\mathrm{Zn}$ in the metalloenzyme alkaline phosphatase, involved in acquisition of phosphate from organophosphate, the influences of $\mathrm{Zn}$ on the potential interfering metal, $\mathrm{Cd}$ were probed. The present study combines physiological experimentation with global proteomic analyses to study the interactions of phosphorus, $\mathrm{Zn}$, and Cd in Synechococcus WH8102. 


\section{Physiological Data}

$\mathrm{Cd}$ may have a hormetic effect in this experiment and the mechanism, albeit unknown, could be in the interaction with $\mathrm{Zn}$. A hormetic response is defined as low dose stimulation, although different concentrations of $\mathrm{Cd}$, both lower and higher would need to be added to get a full hormetic curve, defined as stimulation at low dosages with toxicity at higher dosages (Calabrese, 2005). The instantaneous growth rates in the $\mathrm{Zn}$ treatments, both 1 and $65 \mu \mathrm{M} \mathrm{PO}_{4}{ }^{3-}$, during the last 24 hours of the experiment show an increase in instantaneous growth rates by factors of $\sim 2$ and 1.7 respectively with $4.4 \mathrm{pM}$ $\mathrm{Cd}^{2+}$ addition relative to the no $\mathrm{Cd}$ added (Figure $4.4 \mathrm{~b}$ ). In contrast, there is hardly an increase in instantaneous growth rates in the no $\mathrm{Zn}$ treatments, both 1 and $65 \mu \mathrm{M} \mathrm{PO}_{4}{ }^{3-}$ with the addition of $\mathrm{Cd}$ relative to the no $\mathrm{Cd}$ added, increase by factors of $\sim 1.2$ and $\sim 1.1$, respectively (Figure 4.4b). This may be described as a hormetic response (Calabrese, 2005). The growth of Chlorella, an eukaryotic algae, is stimulated by low concentrations of $\mathrm{Cd}$ and inhibited by higher concentrations (Vallee and Ulmer, 1972). Perhaps the response is favorable due to displacement of $\mathrm{Zn}$ by $\mathrm{Cd}$ and subsequent nutritive use of Zn. Metallothionein is one possible 'Zn buffer' (Frausto da Silva and Williams, 1991) and in mammals upon cadmium and copper loading, metallothionein has been know to release $\mathrm{Zn}$ (Zhang et al., 2003. Alternatively, perhaps the $\mathrm{Cd}$ is directly having a nutritive effect or a regulatory effect inducing cell division. Using this data set, one cannot distinguish between $\mathrm{Cd}$ having a nutritive effect because of its interactions with $\mathrm{Zn}$ or because of $\mathrm{Cd}$ alone.

Relative chlorophyll $a$ and phycoerythrin fluorescence are adequate to monitor cell growth, but they do not accurately show when a culture enters stationary phase. Growth rates calculated using phycoerythrin fluorescence, for example, yielded similar results to actual growth rates in that the four initial treatments had almost identical growth rates (Figure III.2a, 4.4a). Instantaneous growth rates calculated by phycoerythrin fluorescence in the last 24 hours of the experiment, however, indicated that the $1 \mu \mathrm{M} \mathrm{PO}_{4}{ }^{3-}$ treatments entered stationary phase (Figure III.2b). Actual growth rates, calculated using cell numbers, demonstrated that the $\mathrm{Zn}$ added low phosphate treatments 
entered stationary phase during the last 24 hours of the experiment (Figure 4.4b). This disparity in growth phase does suggest that at $1 \mu \mathrm{M} \mathrm{PO}_{4}{ }^{3-}$, during mid-late exponential growth, phycoerythrin perhaps is not being produced even though the cells continue to divide.

\section{Global Proteomic Data}

Tetu et al. (2009) performed a transcriptome analysis of $\mathrm{PO}_{4}{ }^{3-}$ limited and replete cultures in Synechococcus WH8102, as previously mentioned in the results section. In that experiment, Synechococcus WH8102 was grown in SN medium (Waterbury and Willey, 1988) or artificial seawater with $\mathrm{PO}_{4}{ }^{3-}$ concentrations varying from 5 to $87 \mu \mathrm{M}, 5$ $\mu \mathrm{M}$ being P-stressed and $87 \mu \mathrm{M}$ being P-replete. In this experiment, Synechococcus WH8102 was grown in modified Pro-TM medium at a four concentrations: no $\mathrm{PO}_{4}{ }^{3-}$ added, 1, 5, and $65 \mu \mathrm{M} \mathrm{PO}_{4}{ }^{3-}$, finding the cultures to be P-stressed at $1 \mu \mathrm{M} \mathrm{PO}_{4}{ }^{3-}$ (Figure III.1). The global proteomic analyses reported in this chapter, therefore, were from cultures grown at 1 and $65 \mu \mathrm{M} \mathrm{PO}_{4}{ }^{3-}$, low and high $\mathrm{PO}_{4}{ }^{3-}$, respectively. Thirty-six percent of the transcripts that Tetu et al. (2009) reported upregulated (36 total transcripts) under $\mathrm{PO}_{4}{ }^{3-}$ stress in this experiment (13 proteins). Fifteen percent of the total (6 proteins) were found to be $\geq$ two-fold more abundant in the low $\mathrm{PO}_{4}{ }^{3-}$ treatment.

The transcriptome response reported by Tetu et al. (2009) is similar to the proteome response in this experiment. Of the 36 transcripts deemed strongly upregulated by $\geq$ two-fold under early P-stress in the transcriptome study, 13 of these transcripts were identified as proteins in this experiment (Figure 4.12). Of the 13 proteins observed, 6 were $\geq$ two-fold more abundant, including SYNW2391 alkaline phosphatase, SYNW1018 ABC transporter substrate binding protein phosphate (PstS), SYNW0953 cell surface protein required for swimming motility (SwmB), SYNW0799 glyceraldehyde-3-phosphate dehydrogenase and SYNW2224 possible porin (Table 4.1, Figure 4.1 - orange and blue, Figure 4.12 - pink, upper right quadrant), and 7 showed minor changes in abundance, including SYNW1815 ABC transporter substrate binding protein phosphate, SYNW0156 phosphorylase, SYNW0406 hypothetical protein, SYNW1119 6-phosphogluconate dehydrogenase, SYNW1213 thioredoxin peroxidase 
and SYNW2508 molecular chaperone DnaK2, heat shock protein hasp 70-2, and SYNW0160 conserved hypothetical protein (Table 4.2, , Figure 4.12 - black, lower right quadrant). SYNW0156 phosphorylase was close to being $\geq$ two-fold more abundant, it was more abundant in the low $\mathrm{PO}_{4}{ }^{3-}$ compared to the high $\mathrm{PO}_{4}{ }^{3-}$ by a factor of 1.9 . Two more proteins were identified that were $\geq$ two-fold more abundant that were absent from the Tetu list of $\geq$ two-fold upregulated transcripts, SYNW1982 photosystem II chlorophyll-binding protein CP47 and SYNW1147 ribonucleotide reductase (Class II) (Table 4.1). Of the 23 transcripts observed strongly downregulated ( $\geq$ two-fold less) by Tetu et al. (2009) only 3 were identified as proteins, SYNW2340 50S ribosomal protein L7/L12, SYNW2030 conserved hypothetical protein, and SYNW2082 50S ribosomal protein L18, only SYNW2082 50S ribosomal protein L18 was $\geq$ two-fold less in abundance. One might expect less overlap in the protein data from down-regulated transcripts because less protein would presumably be made, reflecting the lower proteome coverage relative to the transcriptome. It is interesting to note that four of these phosphate acquisition genes, in addition to others, increased in expression in a microarray experiment when WH8102 was grown with Vibrio parahaemolyticus, a model heterotroph (Tai et al., 2009). This information, combined with results from previous protein experiments in which these phosphate acquisition genes were more abundant with acute Cd addition in WH8102 stationary phase cultures (Cox et al., unpublished data), suggests that the phosphate response may ultimately be triggered by many factors. 


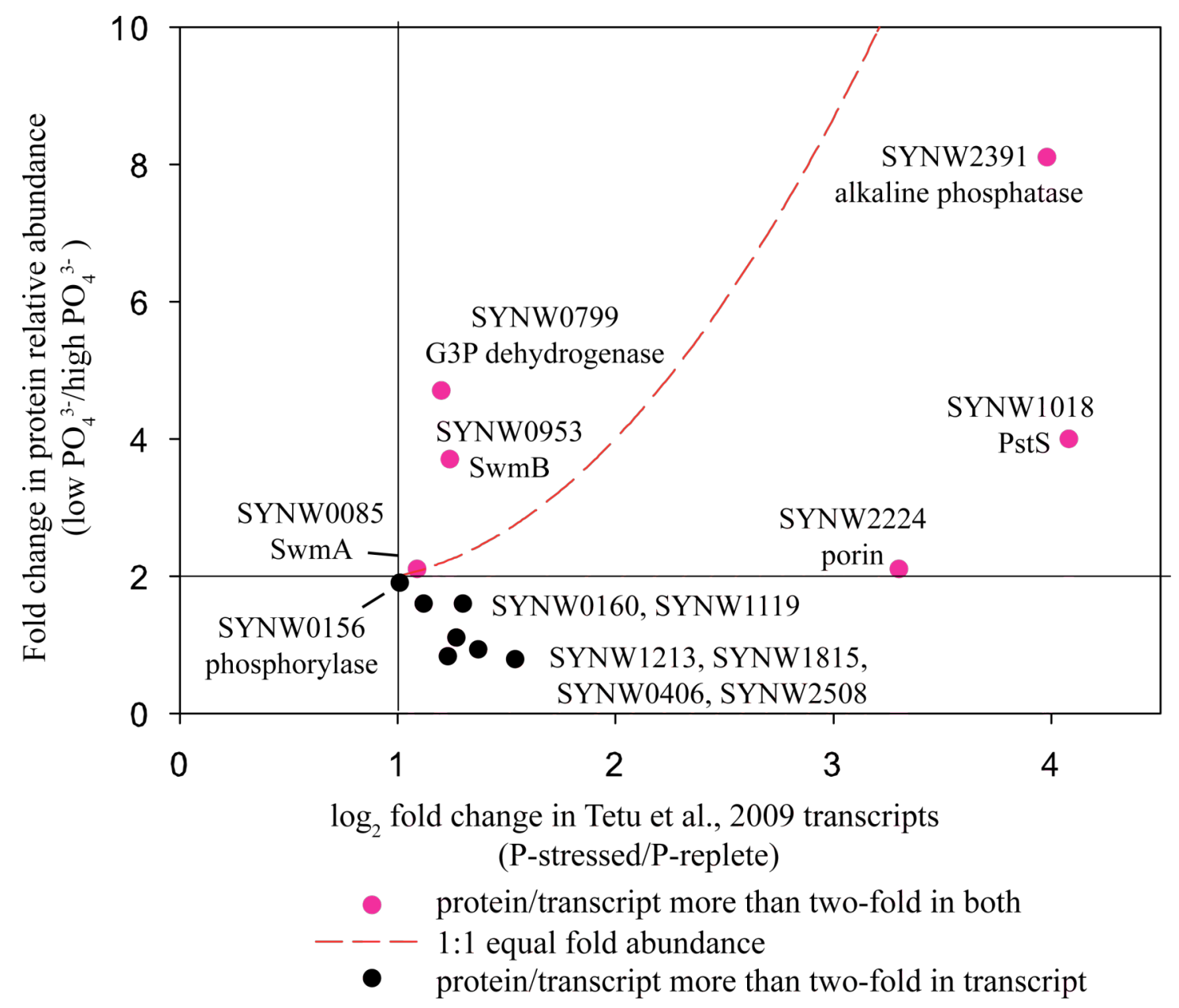

Figure 4.12: Fold change in protein relative abundance (this experiment) as ratio of low phosphate to high phosphate vs. $\log _{2}$ fold change in gene relative abundance (Tetu et al., 2009) as ratio of P-stressed to P-replete. Pink dots represent protein/transcripts more than two-fold abundant in both protein and transcript data. Black dots represent protein/transcripts more than two-fold abundant in transcript data. Red dashed line indicates a 1:1 equal fold abundance. SYNW0160 - conserved hypothetical protein, SYNW1119 - 6-phosphogluconate dehydrogenase, SYNW1213 - thioredoxin peroxidase, SYNW1815 - ABC transporter, substrate binding protein, phosphate, SYNW0406 hypothetical protein, SYNW2508 - molecular chaperone DnaK2, heat shock protein hsp 70-2. See Tables 4.1 and 4.2.

None of the 16 proteins that were $\geq$ two-fold more abundant in the $\mathrm{Zn}$-low $\mathrm{PO}_{4}{ }^{3-}$ compared to $\mathrm{Zn}$-high $\mathrm{PO}_{4}{ }^{3-}$ matched the 55 proteins that were $\geq$ two-fold more abundant in the no $\mathrm{Zn}$-low $\mathrm{PO}_{4}{ }^{3-}$ compared to no $\mathrm{Zn}$-high $\mathrm{PO}_{4}{ }^{3-}$ (Table 4.3, Figure 4.1 - red and black, see also Figure 4.9). In addition, none of the 36 transcripts strongly upregulated under P-stress in the Tetu et al. transcriptome experiment matched the 55 proteins that 
were $\geq$ two-fold more abundant in the no $\mathrm{Zn}$-low $\mathrm{PO}_{4}{ }^{3-}$ compared to no $\mathrm{Zn}$-high $\mathrm{PO}_{4}{ }^{3-}$. If a figure such as Figure 4.12 were to be made, it would be blank. These observations show that the proteome response to low $\mathrm{PO}_{4}{ }^{3-}$ in the absence of $\mathrm{Zn}$ is very different than in the presence of $\mathrm{Zn}$. This could suggest that $\mathrm{Zn}$ is somehow vital to the functioning of the P-stress response in this organism, perhaps as a cofactor in SYNW2391 putative alkaline phosphatase, or in the signaling mechanism.

\section{Alkaline phosphatases}

There are four genes in the genome of WH8102 that are annotated as alkaline phosphatases, SYNW0120 putative alkaline phosphatase-like protein, SYNW0196 putative alkaline phosphatase, SYNW2390 putative alkaline phosphatase/5' nucleotidase, and SNW2391 putative alkaline phosphatase (phoA). In addition, SYNW1799 is an alkaline phosphatase (phoX) (Kathuria and Martiny, 2010). Alkaline phosphatases are variable in their cellular location and associated metal ions. Two alkaline phosphatases purified from different strains of Vibrio cholerae, a gamma-proteobacteria, both acted on a variety of organic phosphate esters, but showed different levels of reactivation upon addition of $\mathrm{Na}^{+}, \mathrm{K}^{+}$and $\mathrm{Mg}^{2+}$ ions (Roy et al., 1982). Alkaline phosphatases (phoA) are thought to be located in the periplasm and are activated by $\mathrm{Zn}$ and magnesium, whereas other alkaline phosphatases (phoX, phoD) are activated by calcium ions (Luo et al., 2009). A recent survey of the metagenomic databases concluded that phoX appeared to be more widespread in the ocean than phoA (Sebastian and Ammerman, 2009). There are also other types of alkaline phosphatases in cyanobacteria. The freshwater cyanobacterium Synechococcus 7942 contains a phoV in addition to phoA (Wagner et al., 1995). PhoV had a broad substrate specificity for phosphomonoesters, required $\mathrm{Zn}^{2+}$ for activity and was inhibited by phosphate, but it was inhibited by $\mathrm{Mn}^{2+}$ (Wagner et al., 1995). Recent experimentation on SYNW1799 phoX overexpressed in E. coli have shown enhanced enzyme activity in the presence of calcium, leading the authors to conclude that bacterial lineages with the presence of phoX in the genome may not be subject to Zn-P colimitation (Kathuria and Martiny, 2010).

In this experiment, we detect SYNW2391 and SYNW1799, but not SYNW0120, 
SYNW2390 or SYN0196 in the proteome. SYNW2391 alkaline phosphatase (phoA) is depicted in Figure 4.9, but SYNW1799 alkaline phosphatase (phoX) is only detected by a few counts, making quantitative comparison difficult. Perhaps it is important that we did not detect high amounts of this protein at low phosphate in the absence of $\mathrm{Zn}$, which is what one might expect from a phoX that does not presumably require $\mathrm{Zn}$.

\section{Metallothionein in Synechococcus $\mathbf{W H 8 1 0 2}$}

As discussed in Chapter 1 on pages 21-22, metallothioneins are small, approximately 56 amino acid residue proteins with a high percentage of cysteine residues that are involved in chelating metals such as zinc, cadmium, copper, silver, mercury, and arsenic (Duncan et al., 2006). Their exact function is elusive but metallothioneins may function as 1) metal resistance proteins for detoxifying zinc, cadmium and copper; 2) reservoirs for the storage of excess $\mathrm{Zn}$ and/or copper than can be mobilized under metal limiting conditions; 3) metal chaperones that deliver $\mathrm{Zn}$ to $\mathrm{Zn}$-dependent proteins; and/or 4) antioxidants that scavenge oxygen radicals (Palmiter, 1998). In these data, metallothionein relative protein abundances look similar to the relative protein abundances of $\mathrm{PO}_{4}{ }^{3-}$ stress proteins (Figure 4.9) and in combination with previous proteome experiments, in which metallothionein was detectable only when $\mathrm{Zn}$ or $\mathrm{Cd}$ was present in the medium (Cox et al., unpublished data), many questions arise: 1) Is metallothionein related to $\mathrm{PO}_{4}{ }^{3-}$ stress? 2) Does it supply the alkaline phosphatase with $\mathrm{Zn}$, acting as a metal reservoir? or 3) is it somehow involved in $\mathrm{Zn}$ signaling and/or the $\mathrm{PO}_{4}{ }^{3-}$ stress signaling mechanism?

Metallothionein abundance appeared to show a dependence on growth phase of the culture, with metallothionein being more abundant with the addition of $\mathrm{Cd}$ and $\mathrm{Zn}$ in stationary phase. The cells in this experiment were harvested during growth phase and metallothionein did not show relative protein abundances in this experiment as expected. Consistent with previous experiments, it is present when there is $\mathrm{Zn}$ in the medium as opposed to no $\mathrm{Zn}$ added, however, it did not increase with acute Cd stress, no matter the $\mathrm{Zn}$ concentration unlike in previous experiments (Cox et al., unpublished data). In previous experiments at $65 \mu \mathrm{M} \mathrm{PO}_{4}{ }^{3-}$ (high phosphate), with $\mathrm{Zn}$ and no $\mathrm{Zn}$ added and 
with and without $\mathrm{Cd}$ addition, cultures were in stationary phase at time of harvest. Metallothionein protein abundance was higher in the $\mathrm{Cd}$ treatments and also in the $\mathrm{Zn}$ treatments (Cox et al., unpublished data). In this experiment, which was expanded to include a low $\mathrm{PO}_{4}{ }^{3-}$ treatment, contrary to the previous experiments, metallothionein did not appear to be more abundant in the presence of $\mathrm{Zn}$ in general, rather metallothionein was high in the $\mathrm{Zn}$ added, low $\mathrm{PO}_{4}{ }^{3-}$ treatment and had a similar relative protein abundance distribution to P-stress proteins (Figure 4.9). More quantitative analyses using a triple quadrupole mass spectrometer would be useful to constrain metallothionein change in WH8102.

\section{The influence of phosphate (pairwise discussion)}

As noted by the ordering of the heat map in Figure 4.7 and the number of proteins differentially abundant in Figure 4.8, phosphate appeared to cause the most difference in this multivariate $\mathrm{Cd}-\mathrm{Zn}$-phosphate interaction experiment. We used the $\mathrm{Zn}$ added treatments to compare to the Tetu et al, 2009 microarray experiment because their media would have $\mathrm{Zn}$ present. We saw 6 of the 9 proteins more abundant as the same proteins differentially expressed in the Tetu et al., 2009 microarray experiment. When Zn was not added, 16 proteins were more abundant but none of them were the same as the Tetu et al., 2009 experiment (Table 4.3). This suggests that $\mathrm{Zn}$ is integral to the phosphate response in this cyanobacterium.

Proteins more abundant in the high phosphate compared to the low phosphate in the absence of $\mathrm{Zn}$ (Table 4.3) suggests that phosphate may be related to the abundance of ribosomal proteins and it is similar, but not exactly the same with or without $\mathrm{Zn}$. Twelve proteins that were $\geq$ two-fold more abundant with high phosphate in the absence of $\mathrm{Zn}$ were involved in genetic information processing, including ten ribosomal proteins, which are involved in protein synthesis. Comparing the high to the low phosphate in the presence of $\mathrm{Zn}$, six ribosomal proteins were $\geq$ two-fold more abundant, three of which were the same proteins as in the no $\mathrm{Zn}$ added treatments (Table 4.1). Note that the tables compare low phosphate to high phosphate.

In the $\mathrm{Zn}$ added $+4.4 \mathrm{pM} \mathrm{Cd}^{2+}$ low compared to high phosphate treatments 
(Figure 4.1 - orange/hatched to blue/hatched), 9 proteins were more abundant in the low phosphate treatment (Table III.1). Of these, five proteins were also found to be $\geq$ twofold differentially abundant with phosphate in the $\mathrm{Zn}$ treatments without $\mathrm{Cd}$ (Table 4.1). Five were expressed as transcripts in a microarray experiment by Tetu et al., 2009 (Table 4.1). These five proteins similar to Zn treatments without Cd were SYNW2391 putative alkaline phosphatase, SYNW1018 ABC transporter, substrate binding protein, phosphate (PstS), SYNW0953 cell-surface protein required for swimming motility (SwmB), and SYNW0359 bacterial metallothionein. Four of the 5 proteins were the same as those found in Tetu et al., 2009, with SYNW0359 bacterial metallothionein present instead of SYNW0156 phosphorylase. One of the four proteins that was differentially abundant with phosphate with Zn added and acute Cd and not Zn alone was SYNW1533 probable glutathione reductase (NADPH); glutathione may be involved in the intracellular binding of $\mathrm{Cd}$ (Table III.1). Eight proteins were more abundant in the $\mathrm{Zn}$ added $+4.4 \mathrm{pM} \mathrm{Cd}^{2+}$ high phosphate treatment compared to the $\mathrm{Zn}$ added $+4.4 \mathrm{pM} \mathrm{Cd}^{2+}$ low phosphate treatment, including three related to the phycobilisomes and two ribosomal proteins, implying perhaps the interference of $\mathrm{Cd}$ in photosynthesis (Table III.1).

In the no $\mathrm{Zn}$ added $+4.4 \mathrm{pM} \mathrm{Cd}^{2+}$ low compared to high phosphate treatments (Figure 4.1 - red/hatched to black/hatched), there were four proteins more abundant in the low phosphate treatment, including two proteins also found to be differentially expressed as genes in the Tetu et al., 2009 microarray experiment (Table III.2). These two proteins are SYNW0953 cell-surface protein required for swimming motility (SwmB) and SYNW1018 ABC transporter, substrate binding protein, phosphate (PstS). Because these two proteins were not observed as being differentially abundant in the absence of added $\mathrm{Zn}$, perhaps the acute addition of $\mathrm{Cd}$ stimulated the presence of these proteins. Eight proteins were more abundant in the no $\mathrm{Zn}$ added $+4.4 \mathrm{pM} \mathrm{Cd}^{2+}$ high phosphate treatment, including six involved in photosynthesis (two phycobilisome, three Photosystem II and one Photosystem I proteins) (Table II.2). In the absence of added Zn, organisms are more vulnerable to $\mathrm{Cd}$ (See Chapter 3), in this case perhaps the process of photosynthesis becomes more vulnerable to $\mathrm{Cd}$ with no added $\mathrm{Zn}$ and low phosphate 
concentrations.

\section{The influence of cadmium (pairwise discussion)}

$\mathrm{Cd}$ effects can be discerned by examining pairwise protein comparisons (Figure 4.8). In the no $\mathrm{Zn}$ added high phosphate $+4.4 \mathrm{pM} \mathrm{Cd}^{2+}$ compared to no $\mathrm{Cd}$ added treatments (Figure 4.1 - black and black/hatched), five proteins were more abundant in the Cd treatment, including three unknown proteins, one involved in photosystem II and one involved in the biosynthesis of riboflavin (Vitamin B2) (Figure 4.10). Perhaps these unknown proteins are involved in $\mathrm{Cd}$ handling in the absence of $\mathrm{Zn}$, because they are not differentially abundant in the treatments with $\mathrm{Zn}$ in the medium. Five proteins were more abundant in the no $\mathrm{Zn}$ added, high phosphate no added $\mathrm{Cd}^{2+}$ treatment, two of which are involved in carbohydrate metabolism (Figure 4.11). Ten additional proteins were found to be significantly different by Fisher's Exact Test, five of which are involved in photosynthesis (Figure 4.10). Three more proteins are statistically more abundant in the no $\mathrm{Zn}$ added high phosphate no added $\mathrm{Cd}^{2+}$, two of which are involved in photosynthesis (Figure 4.11). Perhaps $\mathrm{Cd}$ in the absence of $\mathrm{Zn}$ affects the photosynthetic apparatus.

The number of proteins differentially abundant with acute $\mathrm{Cd}$ addition decreases with $\mathrm{Zn}$ in the media (Figure 4.8b). Only four proteins were $\geq$ two-fold more abundant in the $\mathrm{Zn}$-high $\mathrm{PO}_{4}{ }^{3-}+4.4 \mathrm{pM} \mathrm{Cd}^{2+}$ compared to no $\mathrm{Cd}^{2+}$ added treatments, three of the four are involved in photosynthesis and one SYNW2227 possible porin (som), unknown function, probably outer membrane protein (Table III.3). This porin appears to be more abundant with acute $\mathrm{Cd}$ addition, but only at $65 \mu \mathrm{M} \mathrm{PO}_{4}{ }^{3-}$ concentrations.

In the no $\mathrm{Zn}$-low $\mathrm{PO}_{4}{ }^{3-}+4.4 \mathrm{pM} \mathrm{Cd}^{2+}$ compared to no $\mathrm{Cd}$ added treatments (Figure 4.1 - red and red/hatched), 16 proteins were more abundant in the no $\mathrm{Zn}+\mathrm{Cd}$ treatment, including three ribosomal proteins, a protein involved in chlorophyll biosynthesis and one protein involved in photosynthesis (Table III.4). Sixteen proteins were more abundant in the no $\mathrm{Zn}$-high $\mathrm{PO}_{4}{ }^{3-}$ no added $\mathrm{Cd}$ treatment, including three hypothetical proteins, a protein involved in chlorophyll biosynthesis and two proteins involved in photosynthesis. Compared to only 10 proteins differentially abundant in total at no $\mathrm{Zn}$-high $\mathrm{PO}_{4}{ }^{3-}$ (Figure $4.8 \mathrm{~b}$, Table 4.4), Cd appears to affect the proteome more at 
low $\mathrm{PO}_{4}{ }^{3-}$ in terms of the greater number of proteins differentially abundant.

The number of proteins differentially abundant with acute $\mathrm{Cd}$ addition decreased with $\mathrm{Zn}$ in the media at low $\mathrm{PO}_{4}{ }^{3-}$ (Table III.5). In the $\mathrm{Zn}$-low $\mathrm{PO}_{4}{ }^{3-}+4.4 \mathrm{pM} \mathrm{Cd}^{2+}$ compared to no $\mathrm{Cd}^{2+}$ added treatments, two proteins were more abundant in the $\mathrm{Zn}$-low $\mathrm{PO}_{4}{ }^{3-}+4.4 \mathrm{pM} \mathrm{Cd}^{2+}$ treatment, SYNW1933 $\delta$-aminolevulinic acid dehydratase, which is in the biosynthetic pathway for chlorophyll and SYNW1716 putative carboxysome structural peptide (CsoS2), presumably useful for carbon fixation. Five proteins were more abundant in the $\mathrm{Zn}$-low $\mathrm{PO}_{4}{ }^{3-}$ no added $\mathrm{Cd}^{2+}$ treatment, including one hypothetical protein, a protein involved in lipid metabolism, a protein involved in purine metabolism, a protein involved in carbohydrate metabolism and a protein involved in amino acid metabolism. The acute addition of $\mathrm{Cd}$ decreased the relative protein abundance of metabolic proteins.

\section{The influence of zinc (pairwise comparison)}

$\mathrm{Zn}$ effects can be discerned by examining pairwise protein comparisons (Figure 4.8). In the no $\mathrm{Zn}$-high $\mathrm{PO}_{4}{ }^{3-}$ compared to $\mathrm{Zn}$-high $\mathrm{PO}_{4}{ }^{3-}$ treatments (Figure 4.1 - black and blue), 11 proteins were more abundant in the no $\mathrm{Zn}$-high $\mathrm{PO}_{4}{ }^{3-}$ treatment, including three proteins involved in photosynthesis (SYNW0303 photosystem II manganesestabilizing polypeptide, SYNW1982 photosystem II chlorophyll-binding protein CP47 and SYNW1835 photosystem I reaction center subunit III (PsaF)), two hypothetical proteins, SYNW1933 $\delta$-aminolevulinic acid dehydratase involved in chlorophyll biosynthesis and SYNW0085 cell surface protein required for swimming motility (SwmA) (Table III.6). The photosystem II binding proteins are curious, especially SYNW1982 photosystem II chlorophyll-binding protein CP47, which is similarly abundant in the no $\mathrm{Zn}$-high $\mathrm{PO}_{4}{ }^{3-}$ as the $\mathrm{Zn}$-high $\mathrm{PO}_{4}{ }^{3-}+4.4 \mathrm{pM} \mathrm{Cd}^{2+}$ treatments, both about two-fold greater than $\mathrm{Zn}$-high $\mathrm{PO}_{4}{ }^{3-}$. Perhaps this has to do with the $\mathrm{Zn}$-high $\mathrm{PO}_{4}{ }^{3-}$ entering stationary phase at the time of harvest. Four proteins were more abundant in the Zn-high $\mathrm{PO}_{4}{ }^{3-}$ treatment, including SYNW0670 hypothetical protein, SYNW2191 photosystem II complex extrinsic protein precursor (PsuB) and SYNW2310 glutaredoxin. In the no $\mathrm{Zn}$-low $\mathrm{PO}_{4}{ }^{3-}$ compared to $\mathrm{Zn}$-low $\mathrm{PO}_{4}{ }^{3-}$ treatments (Figure 4.1- red and 
orange), 11 proteins were more abundant in the no $\mathrm{Zn}$-low $\mathrm{PO}_{4}{ }^{3-}$ treatment, including three hypothetical proteins (SYNW0380, SYNW1145 and SYNW0340), two ribosomal proteins and one protein involved in photosynthesis (Table III.7). Because we observed such a response to lower $\mathrm{PO}_{4}{ }^{3-}$ concentrations in treatments with $\mathrm{Zn}$ present, one might expect a response to phosphate in the absence of $\mathrm{Zn}$. Thus, since there is no obvious known $\mathrm{PO}_{4}{ }^{3-}$ response observed in the fold-change protein abundance data, perhaps the hypothetical proteins could be involved in $\mathrm{PO}_{4}{ }^{3-}$ response in the absence of $\mathrm{Zn}$. This could be considered an example of proteome plasticity. Twenty proteins were more abundant in the $\mathrm{Zn}$-low $\mathrm{PO}_{4}{ }^{3-}$ treatment, including SYNW0259 bacterial metallothionein, SYNW2391 putative alkaline phosphatase, SYNW0953 cell surface protein required for swimming mobility (SwmB), three hypothetical proteins (SYNW0128, SYNW0160 and SYNW1661), one protein involved in chlorophyll biosynthesis, SYNW1065 putative photosystem II reaction center (psb28), SYNW1717 ribulose bisphosphate carboxylase small chain and SYNW0082 riboflavin (Vitamin B2) synthase subunit beta. These proteins corroborate the ideas that the presence of $\mathrm{Zn}$ affects the $\mathrm{PO}_{4}{ }^{3-}$ response and the presence of metallothionein is correlated with the presence of $\mathrm{Zn}$.

In the no $\mathrm{Zn}$-high $\mathrm{PO}_{4}{ }^{3-}+4.4 \mathrm{pM} \mathrm{Cd}^{2+}$ compared to $\mathrm{Zn}$-high $\mathrm{PO}_{4}{ }^{3-}+4.4 \mathrm{pM} \mathrm{Cd}^{2+}$ treatments (Figure 4.1 - black/hatched and blue/hatched), SYNW0406 hypothetical protein was more abundant in the absence of $\mathrm{Zn}$ (Table III.8). Two proteins were more abundant with added Zn, SYNW0405 adenylosuccinate lyase, involved in purine and amino acid metabolism and SYNW2500 aconitate hydratase, involved in carbohydrate metabolism, TCA cycle, glyoxylate and dicarboxylate metabolism and energy metabolism, reductive carboxylate cycle (Table II.8). This suggests that in the presence of high $\mathrm{PO}_{4}{ }^{3-}$ and acute $\mathrm{Cd}$ the proteome is not strongly affected by the presence or absence of $\mathrm{Zn}$.

When $\mathrm{Zn}$ was modulated at low $\mathrm{PO}_{4}{ }^{3-}$ with the addition of $\mathrm{Cd}$ (no $\mathrm{Zn}-\mathrm{low} \mathrm{PO}_{4}{ }^{3-}+$ $4.4 \mathrm{pM} \mathrm{Cd}^{2+}$ compared to $\mathrm{Zn}-$ low $\mathrm{PO}_{4}{ }^{3-}+4.4 \mathrm{pM} \mathrm{Cd}^{2+}$ ) (Figure $4.1-\mathrm{red} /$ hatched and orange/hatched), five proteins were more abundant in the no $\mathrm{Zn}$-low $\mathrm{PO}_{4}{ }^{3-}+4.4 \mathrm{pM} \mathrm{Cd}^{2+}$ treatment, including SYNW1815 ABC transporter, substrate binding protein, phosphate 
(PstS) (Table III.9). Four proteins were more abundant in the $\mathrm{Zn}-1$ low $\mathrm{PO}_{4}{ }^{3-}+4.4 \mathrm{pM}$ $\mathrm{Cd}^{2+}$ treatment, including SYNW0359 bacterial metallothionein, SYNW2391 putative alkaline phosphatase and SYNW1533 probable glutathione reductase (NADH) (Table III.9, see also Figure 4.9). The greater abundance of metallothionein and alkaline phosphatase in the $\mathrm{Zn}$ treatment is consistent with $\mathrm{Zn}$ being involved with these proteins. Because $\mathrm{Cd}$ is known to induce the production of metallothioneins in many systems, the metallothionein was expected to be higher in both of these treatments, as opposed to just the $\mathrm{Zn}$ treatment. This may be because of the low spectral counts detected. Further quantification of this protein would be desirable.

\section{Cadmium-zinc interactions (pairwise discussion)}

Holding $\mathrm{PO}_{4}{ }^{3-}$ constant, the comparison of the no $\mathrm{Zn}-$ high $\mathrm{PO}_{4}{ }^{3-}+4.4 \mathrm{pM} \mathrm{Cd}^{2+}$ to $\mathrm{Zn}$-high $\mathrm{PO}_{4}{ }^{3-}$ treatments (Figure 4.1 - blue and black/hatched) will expose $\mathrm{Zn}$ replacement by $\mathrm{Cd}$ or $\mathrm{Cd}$ sensitivity in the absence of $\mathrm{Zn}$ if such occur. Seven proteins were more abundant in the no $\mathrm{Zn}$-high $\mathrm{PO}_{4}{ }^{3-}+4.4 \mathrm{pM} \mathrm{Cd}^{2+}$, including four proteins involved in photosynthesis, SYNW0085 cell surface protein required for swimming motility (SwmA) and SYNW2227 possible porin, unknown function, outer membrane associated (Table III.10). SYNW2500 aconitate hydratase, involved in carbohydrate metabolism, TCA cycle, glyoxylate and dicarboxylate metabolism and energy metabolism, reductive carboxylate cycle was more abundant in the $\mathrm{Zn}$-high $\mathrm{PO}_{4}{ }^{3-}$ treatment (Table III.10). Perhaps the lower abundances of photosynthesis proteins is reflective of the $\mathrm{Zn}$-high $\mathrm{PO}_{4}{ }^{3-}$ treatment entering stationary phase shortly before harvest. Perhaps WH8102 is more sensitive to acute Cd addition in the absence of added Zn. This would be similar to the sensitivity of WH5701 in Chapter 3 to chronic Cd exposure and consistent with previous experiments in which growth rates of WH8102 were decreased with added Cd and low Zn (Saito et al., 2003).

\section{Other proteins of note}

\section{Photosystem II D1 proteins}

The function and evolution of the psbA gene family in marine Synechococcus was investigated fairly recently with marine Synechococcus WH7803 as a case study 
(Garczarek et al., 2008). Basically, the D1 protein of photosystem II is encoded by a family of genes, up to six different genes in as observed in 11 marine cyanobacterial genomes. In each of these genomes, only one of is the D1:1 isoform and the rest are $\mathrm{D} 1: 2$ isoforms; in freshwater cyanobacteria D1:2 isoforms are exchanged for D1:1 isoforms in response to stress, thereby altering photosystem II photochemistry (Garczarek et al., 2008). Synechococcus WH8102 has four psaB genes, one D1:1 and three D1:2. We only detected the D1:1 isoform, at an average low of 2.1 and average high of 4.9 spectral counts. The fact that we only detected the D1:1 isoform suggests that these cultures are not experiencing stress to cause them to use the D1:2 isoform, implies that the D1:2 isoform is below our detection limit, or could mean that the D1:2 isoform does not have a measurable tryptic peptide.

\section{ATP-Binding Cassette Systems}

ABC binding cassette systems use the energy of hydrolysis of ATP to transport a substance across a membrane, as well as being involved in cellular processes and their regulation (Bu et al., 2009). Their reliance on phosphate in ATP makes these systems important to phosphorus cycling. Molecules can be transported into (metals, phosphate, phosphonates, etc) or outside of a cell (heavy metals, drugs, peptides, etc.). In a recent study, the genome of WH8102 was shown to have 41 ABC systems, the highest of the marine Synechococcus genomes included in the analysis (Bu et al., 2009). Note that WH5701 was not included in their analysis. Nineteen ABC systems were common to all 10 marine Synechococcus and 12 Prochlorococcus genomes analyzed, including the import systems of cobalt uptake (CBY), metals, predicted substrate-manganese (MET), phosphonates and phosphates (PHN), oligopeptides and Ni (OPN) and mineral and organic, predicted substrates-phosphate and iron (III) (MOI), and various export systems of drugs, peptides and lipids (DPL) (Bu et al., 2009).

The cyanobase database (website) has 90 genes annotated as ATP-cassette binding systems. We detected 20 of these genes as proteins, $22 \%$. They are listed here with their substrate: SYNW0193 multidrug, SYNW0217 ATP-binding component, SYNW0320 ATP-binding component, SYNW0840 amino acids, SYNW0843 amino 
acids, *SYNW1018 phosphate (PstS), SYNW1112 ATP-binding component, SYNW1169 phosphonate, SYNW1286 possibly phosphate, SYNW1415 nitrate-like, SYNW1541 multidrug, *SYNW1815 phosphate (PstS), *SYNW1797 iron (futA, sfuA, idiA), SYNW1917 glycine betaine, SYNW2175 ATP-binding component, SYNW2325 oligopeptides, *SYNW2442 urea, SYNW2485 cyanate, *SYNW2487 cyanate and SYNW2522 exinuclease (uvrA). Note that the five ABC system components that were overall most abundant in terms of spectral counts (starred) are involved with the essential elements phosphorus, iron and nitrogen. PstS is also seen upregulated in

Prochlorococcus under P-stress (Martiny et al., 2006).

\section{Polyphosphate}

The fine structure of cyanobacteria has been of interest for many years (Lang, 1968). Granules had been noticed that differed in size and abundance with amount of $\mathrm{PO}_{4}{ }^{3-}$ in the medium and age or developmental stage of cell, bigger and more granules present with more $\mathrm{PO}_{4}{ }^{3-}$ and the older the cell (Lang, 1968). Although dissolved $\mathrm{PO}_{4}{ }^{3-}$ concentrations in the oceans are rarely more than $2 \mu \mathrm{M}$, many marine Synechococcus have the genes related to polyphosphate metabolism, Synechococcus WH8102 and Synechococcus WH5701 included. Because phosphorus is such a vital element to life and marine cyanobacteria are not exposed to high $\mathrm{PO}_{4}{ }^{3-}$ concentrations in the environment, this suggests that the polyphosphate metabolism may be vestigial or alternatively, laterally transferred. Although we may not expect to observe polyphosphates in cyanobacteria gathered directly from the ocean, we expect to see polyphosphates in cultures grown with excess phosphate.

Polyphosphate is proposed to interact with $\mathrm{Cd}$. Chlamydomonas acidophila, a eukaryotic algae, dramatically changes its cellular structure in the presence of 10 and 20 $\mu \mathrm{M} \mathrm{Cd}$, causing the degradation of polyphosphate and increased short-chain and orthophosphates in the vacuole (Nishikawa et al., 2003). Other researchers have reported the presence of $\mathrm{Cd}$ deposits in vacuoles of Saccharomyses cerevisiae, baker's yeast, with corresponding high quantities of phosphorus by electron microscopy (Volesky et al., 1992). In the unicellular cyanobacterium Anacystis nidulans R2, cells with a large 
polyphosphate reserve showed a greater tolerance to $0.02 \mathrm{ppm} \mathrm{Cd}$ than cells with a small polyphosphate reserve (Keyhani et al., 1996). They propose that a decrease in polyphosphate reserves results in fewer sites for $\mathrm{Cd}$ chelation and thus a higher intracellular concentration of metals (Keyhani et al., 1996). This led one of the authors to later propose that although in many microorganisms polyphosphate is correlated with heavy metal tolerance, the ability to degrade orthophosphate may result in the binding of metals to orthophosphate and the removal of the resulting metal phosphates by the inorganic phosphate transport system (Keasling, 1997). A recent study by Zeng and Wang 2009 found that elevated cellular phosphate concentrations increased the shortterm uptake of $\mathrm{Cd}$ and $\mathrm{Zn}$ in the freshwater cyanobacterium, Microcystis aeruginosa. They propose that polyphosphate bodies may have served as a metal sink to sequester/detoxify the Cd and Zn (Zeng and Wang, 2009).

Polyphosphates are relevant to phosphorus cycling in the ocean. In a fairly recent study of a site in a Pacific fjord off of Vancouver Island, British Columbia with surface water total dissolved phosphate concentrations of $0.5 \mu \mathrm{M}, \sim 11 \%$ of the total dissolved phosphorus pool, $7 \%$ of total phosphorus in surface water biomass and $7 \%$ of total phosphorus in sinking material was polyphosphate (Diaz et al., 2008). These data and other supporting evidence led the authors to conclude that diatom-derived polyphosphates play a critical role in the formation of calcium phosphate minerals observed in marine sediments worldwide (Diaz et al., 2008).

Two important enzymes in the metabolism of polyphosphate were observed at low spectral counts in this experiment SYNW1846 putative exopolyphosphatase (ppx), which removes a phosphate from polyphosphate, and SYNW2495 polyphosphate kinase (ppk), which forms polyphosphate using ATP, but not at a high enough abundance for comparative analysis. SYNW2270 predicted inorganic polyphosphate/ATP NAD ${ }^{+}$kinase was not detected. These proteins have potential for future research. Direct measurement of polyphosphate alongside proteomic analysis would yield valuable information about the interaction of $\mathrm{Cd}$ and polyphosphate. 


\section{The physiological response to $\mathrm{Cd}$ addition may be nutritive at low $\mathrm{PO}_{4}{ }^{3-}$ and added $\mathrm{Zn}$}

The instantaneous ( 24 hour) growth rates and higher cell counts in the added $\mathrm{Zn}$ low phosphate with added $\mathrm{Cd}$ would imply that $\mathrm{Cd}$ is acting like a nutrient. Perhaps this is by the direct use of $\mathrm{Cd}$ as a nutrient or the release of an intracellular pool of $\mathrm{Zn}$ due to Cd exposure (Figure 4.4b, 4.5). This nutritive effect of Cd was not observed in any of the other treatments.

\section{Biochemical branch point - insertion of a metal ion - heme to chlorophyll}

The insertion of a metal ion into protoporphyrin IX determines the biochemical fate of the molecule. It is a branch point in the biochemical pathway of heme proteins, including phycobilins and chlorophyll. If an iron atom is inserted by ferrochelatase, the molecule is destined to be a heme or biliverdin. If a $\mathrm{Mg}$ is inserted by $\mathrm{Mg}$-chelatase, the molecule is destined to be chlorophyll. Mg-chelatase uses energy from the hydrolysis of ATP to insert a $\mathrm{Mg}^{2+}$ ion into porphyrin (Reid and Hunter, 2002). Branch-point enzymes such as these are tightly regulated according to the prevailing metabolic conditions (Walker and Willows, 1997). As was mentioned in Chapter 3, Cd has been known to substitute for Mg in chlorophylls in higher plants (Küpper et al., 1998). Cd could substitute into a porphyrin without enzymatic catalysis. There is the potential for $\mathrm{Cd}$ to affect these enzymes. There are five annotated genes for chelatases in WH8102: SYNW0213 protoporphyrin IX Mg-chelatase subunit (chlD), SYNW0327 Mg-chelatase family protein, SYNW0716 protoporphyrin IX Mg-chelatase subunit (chlI), SYNW0820 protoporphyrin IX Mg-chelatase subunit (chlH) (cyanobase, NCBI annotates as cobaltochelatase) and SYNW1747 ferrochelatase. We detect three of these at low spectral counts in this experiment, SYNW0213 protoporphyrin IX Mg-chelatase subunit (chlD), SYNW0820 protoporphyrin IX Mg-chelatase subunit (chlH) (cyanobase, NCBI annotates as cobaltochelatase) and SYNW0716 protoporphyrin IX Mg-chelatase subunit (chlI). Quantitative studies of these enzymes could be applied for further study.

\section{Vitamin D}

The response of a culture to acute $\mathrm{Cd}$ addition could be akin to a culture exposed to intense light. The vitamin $\mathrm{D}$ family (Vitamin $\mathrm{D}_{2}$ and $\mathrm{D}_{3}$ ) comprises fat soluble 
secosteroids. Vertebrates require the active form $\left(1,25(\mathrm{OH})_{2} \mathrm{D}_{3}\right)$ to be physiologically functional in terms of calcium and bone metabolism (Holick, 1989). Provitamin D (ergosterol) is produced in fungi, plants, animals, phytoplankton, and zooplankton (Holick, 1989). Vitamin D has been relatively little studied in the ocean. A study documents the production of previtamin $\mathrm{D}_{2}$ (ergosterol) in cultures of Emiliania huxleyi and proposes that the provitamin D and family of compounds evolved as natural sunscreens to absorb damaging UV radiation (Holick et al., 1982). Two additional ideas as to the functionality of vitamin D are photodegradation as a photochemical signal directly correlating to amount of UV exposure in an organism and the opening of ergosterol ring in the cell membrane upon UV exposure resulting in membrane permeability to allow cations such as calcium into a cell (Holick, 2003). In mammalian systems, vitamin $\mathrm{D}$ is thought to be a hormonal link between $\mathrm{Zn}^{2+}$ and $\mathrm{Ca}^{2+}$ (da Silva and Williams, 1991). In these systems, vitamin D controls the expression of calbindin, a protein involved in $\mathrm{Ca}^{2+}$ transport and metallothionein, a proposed $\mathrm{Zn}$ 'buffer' (da Silva and Williams, 1991). Vitamin D was also observed to stimulate $\mathrm{Ca}$ and $\mathrm{PO}_{4}{ }^{3-}$ uptake across the brush border boundary in chick intestines by increasing the $V_{\max }$ of these carrier-mediated processes (Matsumoto and Rasmussen, 1982). Perhaps vitamin D is partially regulating the presence of metallothionein in cyanobacteria. Metallothionein is more abundant when $\mathrm{Zn}$ is added (Figure 4.9) and in a different experiment with 8102, harvested in stationary phase, acute $\mathrm{Cd}$ addition correlated with increased metallothionein abundance, whether or not Zn was added. Very little is known about Vitamin D in cyanobacteria. One Vitamin D receptor in a Prochlorococcus genome is annotated.

\section{CONCLUSIONS}

In conclusion, the physiologic response of Synechococcus WH8102 to acute 4.4 pM free $\mathrm{Cd}^{2+}$ under four varying $\mathrm{Zn}$ and $\mathrm{PO}_{4}{ }^{3-}$ treatments $\left(\mathrm{Zn}\right.$-high $\mathrm{PO}_{4}{ }^{3-}$, no $\mathrm{Zn}$-low $\mathrm{PO}_{4}{ }^{3-}$, no $\mathrm{Zn}$-high $\mathrm{PO}_{4}{ }^{3-}$, and no $\mathrm{Zn}$-low $\mathrm{PO}_{4}{ }^{3-}$ ) revealed during the last 24 hours of the experiment relative to the high $\mathrm{PO}_{4}{ }^{3-}$ conditions: 1) increased growth rates under low $\mathrm{PO}_{4}{ }^{3-}$ conditions and 2) even greater increased growth rates with $\mathrm{Cd}$ addition under low 
$\mathrm{PO}_{4}{ }^{3-}$ and $\mathrm{Zn}$ conditions. The proteomic response revealed differential abundances of $\mathrm{PO}_{4}{ }^{3-}$ stress proteins comparing low to high $\mathrm{PO}_{4}{ }^{3-}$ conditions and differential protein abundances with chronic $\mathrm{Zn}$ and acute $\mathrm{Cd}$. Considering the proteomic data, it appears that $\mathrm{Zn}$ is vital to the $\mathrm{PO}_{4}{ }^{3-}$ response in this organism because 1) $\mathrm{Cd}$ causes more proteomic changes at low $\mathrm{PO}_{4}{ }^{3-}$ and 2) in the presence of high $\mathrm{PO}_{4}{ }^{3-}$ and acute $\mathrm{Cd}$ the proteome is relatively indifferent to the presence of $\mathrm{Zn}$. These findings are consistent with the ideas that $\mathrm{Zn}$ is beneficial for the functioning of alkaline phosphatase and other proteins involved in $\mathrm{PO}_{4}{ }^{3-}$ acquisition, and at environmentally relevant $\mathrm{PO}_{4}{ }^{3-}$ concentrations the presence of $\mathrm{Zn}$ and $\mathrm{Cd}$ make a difference in the physiology and proteome of cells, perhaps by influencing regulation.

Comparison of proteomic data to literature transcriptome analyses shows a similar response of many important P-stress related proteins (putative alkaline phosphatase, periplasmic ABC phosphate binding protein (PstS), motility-related proteins (SwmA and SwmB), and possible porin), but also shows other proteins that did not respond in the microarray study, bacterial metallothionein (SmtA), as well as proteins that did respond in the microarray study and not this one, thioredoxin peroxidase. These data suggest that there is a fair amount of consistency between the transcriptome and proteome under Pstress. Taken together with the fact that the treatments without $\mathrm{Zn}$ showed a different proteomic reaction to phosphorus stress, the presence of $\mathrm{Zn}$ appears important to the phosphorus metabolism of this open ocean cyanobacterium.

\section{FUTURE RESEARCH}

Quantitative analyses by triple quadrupole of metallothioneins, alkaline phosphatases, polyphosphates and chelatases would yield useful information. Unfortunately, the peptides needed for the quantification of this particular metallothionein are unable to be produced using current commercially available methods, probably because of the high number of cysteine residues.

A repeat experiment with analysis of protein across late growth phase into stationary phase would be advantageous because physiologically and proteomically, 
much changes across this late-log to stationary phase transition. Time course experiments have not been performed thus far with Synechococcus WH8102 and detail across this transition would be revealing. A time course experiment with chronic $\mathrm{Cd}$ exposure could be performed and compared to Synechococcus WH5701, yielding a comparison of chronic exposure from a coastal to an open ocean cyanobacterium.

In addition, the microarray is available for WH8102. It would be possible to collect for transcriptome analyses at the some time and compare gene expression with protein abundance directly. Also, genetic manipulations of WH8102 are possible to perform if one was interested in detailed gene functionality (Brahamsha, 1996). 


\section{REFERENCES}

Blindauer, C.A. 2008a. Zinc-handling in cyanobacteria: An update. Chemistry and Biodiversity 5: 1990- 2013.

Blindauer, C.A. 2008b. Metallothioneins with unusual residues: Histidines as modulators of zinc affinity and reactivity. Journal of Inorganic Biochemistry 102: 507-521.

Boyle, E.A., Sclater, F. and Edmond, J.M. 1976. On the marine geochemistry of cadmium. Nature 263: 42-44.

Boyle, E.A. 1988. Cadmium: chemical tracer of deepwater paleoceanography. Paleoceanography 3:471-489.

Brahamsha, B. 1996. A genetic manipulation system for oceanic cyanobacteria of the genus Synechococcus. Applied and Environmental Microbiology 62: 1747-1751.

Brand, L.E., Sunda, W.G. and Guillard, R.R.L. 1986. Reduction of marine phytoplankton reproduction rates by copper and cadmium. Journal of Experimental Marine Biology and Ecology 96: 225-250.

Bruland, K. W. 1980. Oceanographic distributions of cadmium, zinc, nickel, and copper in the North Pacific. Earth and Planetary Science Letters 47: 176-198.

Bruland, K.W. 1989. Complexation of zinc by natural organic ligands in the central North Pacific. Limnology and Oceanography 34: 269-285.

Bu, L., Xiao, J., Lu, L., Xu, G., Li, J., Zhao, F., Li, X. and Wu, J. 2009. The repertoire and evolution of ATP-binding cassette systems in Synechococcus and Prochlorococcus. Journal of Molecular Evolution 69 (4): 300-310.

Cullen, J. 2006. On the nonlinear relationship between dissolved cadmium and phosphate in the modern global ocean: Could chronic iron limitation of phytoplankton growth cause the kink? Limnology and Oceanography: 51(3): 1369-1380.

Diaz, J., Ingall, E., Benitez-Nelson, C., Paterson, D., de Jonge, M. D., McNulty I. and Brandes, J.A. 2008. Marine polyphosphate: A key player in geologic phosphorus sequestration. Science 320: 652-655.

Duncan, K.E.R., Ngu, T.T., Chan, J., Salgado, M.T., Merrifield, M.E. and Stillman, M.J. 2006. Peptide folding, metal-binding mechanisms, and binding site structures in metallothioneins. Experimental Biology and Medicine 231: 1488-1499. 
Eisen, M.B., Spellman, P.T., Brown, P.O., and Bostein, D. 1998. Cluster analysis and display of genome-wide expression patterns. PNAS 95(25): 14863-14868.

Frausto da Silva, J.R.R. and Williams, R.J.P. 1991. The Biological Chemistry of the Elements: The Inorganic Chemistry of Life. Oxford University Press.

Fuller, N.J., Marie, D., Partensky, F., Vaulot, D., Post, A.F. and Scanlan, D. J. 2003. Clade-specific 16S ribosomal DNA oligonucleotides reveal the predominance of a single marine Synechococcus clade in a stratified water column in the Red Sea. Applied and Environmental Microbiology 69: 2430-2443.

Garczarek, L., Dufresne, A., Blot, N., Cockshutt, A. M., Peyrat, A., Campbell, D.A., Joubin, L. and Six, C. 2008. Function and evolution of the psbA gene family in marine Synechococcus: Synechococcus sp. WH7803 as a case study. The ISME Journal 2: 937953.

Holick, M.F. 1989. Phylogenetic and evolutionary aspects of vitamin D from phytoplankton to humans. In: Schreibman P, Pang M, editors. Vertebrate endocrinology: Fundamentals and biomedical implications. San Diego: Academic Press.Vertebrate Endocrinology pp 7-43.

Holick, M. F. 2003. Vitamin D: A millenium perspective. Journal of Cellular Biochemistry 88 (2): 296-307.

Holick, M.F., Holick, S.A. and Guilliard, R.L. 1982. On the origin and metabolism of Vitamin D in the sea. In: Oguro C, Pang P, editors. Comparative endocrinology and calcium regulation. Tokyo: Sci Soc Press pp. 85-91.

Frausto da Silva, J.R.R. and Williams, R.J.P. 1991. The Biological Chemistry of the Elements: The Inorganic Chemistry of Life. Oxford University Press.

Karl, D.M. 2000. Phosphorus, the staff of life. Nature 406: 31-32.

Kathuria, S. and Martiny, A. C. 2010. Prevalence of a calcium-based alkaline phosphatase associated with the marine cyanobacterium Prochlorococcus and other ocean bacteria. Environmental Microbiology doi:10.1111/j.1462-2920.2010.02310.x.

Keasling, J.D. 1997. Regulation of intracellular toxic metals and other cations by hydrolysis of polyphosphate. Annals of the New York Academy of Sciences 829:242-249.

Keyhani, S., Lopez, J. L., Clark, D. S. and Keasling, J.D. 1996. Intracellular polyphosphate content and cadmium tolerance in Anacystis nidulans R2. Microbios 88:105-114. 
Küpper, H., Küpper, F. and Spiller, M. 1998. In situ detection of heavy metal substituted chlorophylls in water plants. Photosynthesis Research 58: 123-133.

Ilikchyan, I. N., McKay, R. M., Zehr, J. P., Dyhrman, S. T., and Bullerjahn, G.S. 2009. Detection and expression of the phosphonate transporter gene phnD in marine and freshwater picocyanobacteria. Environmental Microbiology 11(5): 1314-24.

Lane, E.S., Semeniuk, D. M., Strzepek, R. F., Cullen, J.T., and Maldonado, M. T. 2009. Effects of iron limitation on intracellular cadmium of cultured phytoplankton: Implications for surface dissolved cadmium to phosphate ratios. Marine Chemistry 115: $55-162$.

Lane, T.W. and Morel, F.M.M. 2000. A biological function for cadmium in marine diatoms. Proceedings of the National Academy of Sciences 97: 4627-4631.

Lang, N.J. 1968. The fine structure of blue-green algae. Annual Review of Microbiology 22:15-46.

Lee, J.G. and Morel, F.M.M. 1995. Replacement of zinc by cadmium in marine phytoplankton. Marine Ecology Progress Series 127:305-309.

Lee, JG., Roberts, S.B. and Morel, F.M.M. 1995. Cadmium: a nutrient for the marine diatom Thalassioria weissflogii. Limnology and Oceanography 40:1056-1063.

Luo, H., Benner, R., Long, R. A. and Hu J. 2009. Subcellular localization of marine bacterial alkaline phosphatases. PNAS 106: 21219-21223.

Martiny, A.C, Coleman, M. L. and Chisholm, S.W. 2006. Phosphate acquisition genes in Prochlorococcus ecotypes: Evidence for genome-wide adaptation. PNAS 103(33): 12552-12557.

Martelli, A. E. Rousselet, Dycke, C., Bouron, A. and Moulis, J.-M. 2006. Cadmium toxicity in animal cells by interference with essential metals. Biochimie 88 (11):18071814.

Matsumoto, T. and Rasmussen, H. 1982. Mechanism of acation of 1,25(OH)2D3 on chick intestinal calcium and phosphate transport. In: Oguro C, Pang P, editors. Comparative endocrinology and calcium regulation. Tokyo: Sci Soc Press pp. 85-91.

Moore, L. R., Ostrowski, M., D.J. Scanlan, D. J., Feren, K. and Sweetsir, T. 2005. Ecotypic variation in phosphorus-acquisition mechanisms within marine picocyanobacteria. Aquatic Microbial Ecology 39: 257-269 
Morel, F.M.M., Milligan, A.J. and Saito, M.A. 2003. Marine bioinorganic chemistry: The role of trace metals in the oceanic cycles of major nutrients. Treatise on Geochemistry Volume 6 The Oceans and Marine Geochemistry. eds. Henry Elderfield. H.D. Holland and K.K. Turekian. 6.05: 113-143.

Nishikawa, K., Yamakoshi, Y., Uemura, I. and Tominaga, N. 2003. Ultrastructural changes in Chlamydomonas acidophila (Chlorophyta) induced by heavy metals and polyphosphate metabolism. FEMS Microbiology Ecology: 44(2):253-259.

Okamura, M. Y., Paddock, M. L., Graige, M. S., and Feher, G. 2000. Proton and electron transfer in bacterial reaction centers. Biochimica et Biophysica Acta-Bioenergetics 1458 (1): 148-163.

Ostrowski, M., Mazard, S., Tetu, S. G., Phillippy, K., Johnson, A., Palenik, B., Paulsen, I. T. and Scanlan, D. J. 2010. PtrA is required for coordinate regulation of gene expression during phosphate stress in a marine Synechococcus. The ISME Journal 4: 908-921.

Palenik, B., Ren, Q., Dupont, C.L., Myers, G.S., Heidelberg, J.F., Badger, J.H., Madupu, R., Nelson, W.C., Brinkac, L.M., Dodson, R.J., Durkin, A.S., Daugherty, S.C., Sullivan, S.A., Khouri, H., Mohamoud, Y., Halpin, R. and Paulsen, I.T. 2006. Genome sequence of Synechococcus CC9311: Insights into adaptation to a coastal environment. PNAS: 103(36): 13555-13559.

Palmiter, R.D. 1998. The elusive function of metallothioneins. PNAS 95: 8428-8430.

Park, H., Song, B. and Morel, F. M. M. 2007. Diversity of the cadmium-containing carbonic anhydrase in marine diatoms and natural waters. Environmental Microbiology 9(2): 403-413.

Payne, C.D. and Price, N.M 1999. Effects of cadmium toxicity on growth and elemental composition of marine phytoplankton. Journal of Phycology 35:293-302.

Peng, J., Elias, J. E., Thoreen, C. C., Licklider, L. J. and Gygi, S. P. 2003. Evaluation of multidimensional chromatography coupled with tandem mass spectrometry (LC/LCMS/MS) for large-scale protein analysis: The yeast proteome. Journal of Proteome Research 2: 43-50.

Price, N.M. and Morel, F.M.M. 1990. Cadmium and cobalt substitution for zinc in a marine diatom. Nature 344:658-660.

Reid, J.D. and Hunter, C.N. 2002. Current understanding of the function of magnesium chelatase. Biochemical Society Transactions 30: 643-645. 
Rocap, G., Distel, D.L., Waterbury, J.B. and Chisholm, S.W. 2002. Resolution of Prochlorococcus and Synechococcus ecotypes by using 16S-23S ribosomal DNA internal transcribed spacer sequences. Applied and Environmental Microbiology 68(3):11801191.

Saito, M.A., Sigman, D.M. and Morel, F.M.M. 2003. The bioinorganic chemistry of the ancient ocean: the co-evolution of cyanobacterial metal requirements and biogeochemical cycles at the Archean-Proterozoic boundary? Inorganica Chimica Acta 356:308-318.

Saito, M.A, Goepfert, T.J. and Ritt, J. 2008. Some thoughts on the concept of colimitation: Three definitions and the importance of bioavailability. Limnology and Oceanography 53(1): 276-290.

Saito, M. A., Goepfert, T. J., Noble, A. E., Bertrand, E. M., Sedwick, P. N. and DiTullio, G. R. 2010. A seasonal study of dissolved cobalt in the Ross Sea, Antarctica: micronutrient behavior, absence of scavenging, and relationships with $\mathrm{Zn}, \mathrm{Cd}$, and $\mathrm{P}$. Biogeosciences 7: 4059-4082.

Sebastian, M. and Ammerman, J. W. 2009. The alkaline phosphatase PhoX is more widely distributed in marine bacteria than the classical PhoA. The ISME Journal 3: 563572.

Shaked, Y., Xu, K., Leblanc, K. and Morel, F. M. M. 2006. Zinc availability and alkaline phosphatase activity in Emiliania huxleyi: Implications for Zn-P co-limitation in the ocean. Limnology and Oceanography 51: 299-309.

Su, Z., Dam, P., Chen, X., Olman, V., Jiang, T., Palenik, B. and Xu, Y. 2003. Computational Inference of Regulatory Pathways in Microbes: an Application to Phosphorus Assimilation Pathways in Synechococcus sp. WH8102. Genome Informatics 14: 3-13.

$\mathrm{Su}, \mathrm{Z}$., Olman, V. and Xu, Y. 2007. Computational prediction of Pho regulons in cyanobacteria. BMC Genomics 8:156.

Sunda, W.G. and Huntsman, S.A. 2000. Effect of Zn, Mn, and Fe on Cd accumulation in phytoplankton: Implications for oceanic Cd cycling. Limnology and Oceanography 45(7): 1501-1516.

Tai, V., Paulsen, I.T., Phillippy, K., Johnson, D.A. and Palenik, B. 2009. Whole-genome microarray analyses of Synechococcus-Vibrio Interactions. Environmental Microbiology 11(10): 2698 - 2709. 
Tetu, S. G., Brahamsha, B., Johnson, D. A., Tai, V., Phillippy, K., Palenik, B. and Paulsen, I. T. 2009. Microarray analysis of phosphate regulation in the marine cyanobacterium Synechococcus sp. WH8102. ISME Journal 3: 835-849.

Vallee, B.L. and Ulmer, D.D.1972. Biochemical effects of mercury, cadmium and lead. Annual Review of Biochemistry 41: 91-128.

Volesky, B., May, H. and Holan Z.R. 1993. Cadmium biosorption by Saccharomyces cerevisiae. Biotechnology and Bioengineering 41: 826-829.

Walker, C.J. and Willows, R. D.. 1997. Mechanism and regulation of Mg-chelatase. Biochemical Journal 327: 321-333.

Waterbury, J. B. and Willey, J.M. 1988. Isolation and growth of marine planktonic cyanobacteria. Methods in Enzymology 167: 100-105.

Xu, Y., Feng, L., Jeffrey, P. D., Shi, Y. and Morel, F. M. M. 2008. Structure and metal exchange in the cadmium carbonic anhydrase of marine diatoms. Nature 452: 56-61.

Zeng, J. and Wang, W. 2009. The importance of cellular phosphorus in controlling the uptake and toxicity of cadmium and zinc in Microcystis aeruginosa, A freshwater cyanobacterium. Environmental Toxicology and Chemistry 28(8): 1618-1626.

Zhang, B., VerBerkmoes, N. C., Langston, M.A., Uberbacher, E., Hettich, R. L. and Samatova, N. F. 2006. Detecting differential and correlated protein expression in labelfree shotgun proteomics. Journal of Proteome Research 5(11): 2909-2918.

Zhang, B., Georgiev, O., Hagmann, M., Günes, Ç., Cramer, M., Faller, P., Vasák, M. and Schaffner, W. 2003. Activity of metal-responsive transcription factor 1 by toxic heavy metals and $\mathrm{H}_{2} \mathrm{O}_{2}$ in vitro is modulated by metallothionein. Molecular and Cellular Biology 23 (23): 8471-8485. 


\section{Chapter 5: Conclusions}

In summary, the combination of uptake field studies on natural phytoplankton assemblages and laboratory proteomic and physiological experiments on cyanobacterial isolates have yielded much information about the interactions of cadmium, zinc, and phosphorus in the ocean and in marine Synechococcus. Environmentally relevant concentrations of total dissolved $\mathrm{Cd}$ in the ocean range from lower than $\mathrm{pM}$ in shallow water to around $1 \mathrm{nM}$ in deeper waters and EDTA-buffered culture media experiments were performed with free concentrations in this range.

Enriched stable isotope uptake field studies using picomolar additions of ${ }^{110} \mathrm{Cd}$ in the Costa Rica Upwelling dome showed that the intermediate abundance enriched $\mathrm{Cd}$ stable isotope tracer method appears to function as long as the total dissolved natural $\mathrm{Cd}$

present is below $\sim 200 \mathrm{pM}$. Overall, uptake of ${ }^{110} \mathrm{Cd}$ occurs in waters shallower than $40 \mathrm{~m}$, the uptake rate of ${ }^{110} \mathrm{Cd}$ correlates positively with chlorophyll $a$ concentrations, ${ }^{110} \mathrm{Cd}$ uptake increases with time, a single 24-hour time point seems adequate to measure ${ }^{110} \mathrm{Cd}$ uptake rates in environmental samples at sea, preexisting particulate $\mathrm{Cd}$ must be considered especially in high biomass regions, calculated upwelling flux of $\mathrm{Cd}$ is roughly equivalent to uptake flux into the particulate fraction inside the dome, and stations inside the dome do not show a decrease in chlorophyll $a$ concentrations with added $\mathrm{Cd}$ up to 5 $\mathrm{nM}$ whereas stations outside the dome do.

The physiological and proteomic effects of two levels of chronic Cd exposure (4.4 and $44 \mathrm{pM} \mathrm{Cd}^{2+}$ ) over the life cycle of a little-studied coastal cyanobacterium representative of the natural population in the Baltic Sea, Synechococcus WH5701, revealed that cells exposed to $\mathrm{Cd}$ under $\mathrm{Zn}$ deficiency appear to be physiologically robust during exponential growth phase, showing no difference in growth rates or fluorescence, but their proteome was quite different compared to cultures with no added $\mathrm{Cd}$. The proteome of exponential cultures with $\mathrm{Cd}$ added showed differences in relative abundances of proteins involved in chlorophyll $a$ biosynthesis, photosynthesis, carbon fixation, steroid and lipid biosynthesis, sulfur and cysteine metabolism, and genetic information processing suggesting a great metabolic impact. During stationary phase, 
chronic $\mathrm{Cd}$ exposure caused an increase in relative chlorophyll $a$ fluorescence and faster mortality rates. The proteome changed during exponential phase and throughout stationary phase. This is the first detailed proteomic study over the life cycle of Synechococcus and of chronic $\mathrm{Cd}$ exposure under $\mathrm{Zn}$ deficiency. It also showed that $\mathrm{Cd}$ may be used to indicate where $\mathrm{Zn}$ is important in a cell.

The interactions of acute $\mathrm{Cd}\left(4.4 \mathrm{pM}\right.$ free $\left.\mathrm{Cd}^{2+}\right)$ exposure under a matrix of $\mathrm{Zn}$ deficient (no added $\mathrm{Zn}^{2+}$ ) and $\mathrm{Zn}$ replete (tens of picomolar free $\mathrm{Zn}^{2+}$ ), low $\mathrm{PO}_{4}{ }^{3-}(1 \mu \mathrm{M})$ and high $\mathrm{PO}_{4}{ }^{3-}(65 \mu \mathrm{M})$ conditions in the well-studied open-ocean cyanobacterium, Synechococcus WH8102, revealed a number of physiological and proteomic results. Low $\mathrm{PO}_{4}{ }^{3-}$ cultures had higher growth rates during the last 24 hours of the experiment than the high $\mathrm{PO}_{4}{ }^{3-}$ and had even higher growth rates with the addition of $\mathrm{Cd}$ in both the low $\mathrm{PO}_{4}{ }^{3-}$ and $\mathrm{Zn}$ added treatments. The proteomic response to low $\mathrm{PO}_{4}{ }^{3-}$ was different under $\mathrm{Zn}$ deficient and $\mathrm{Zn}$ replete conditions, which suggests that the presence of $\mathrm{Zn}$ is vital to the response of the organism to different $\mathrm{PO}_{4}{ }^{3-}$ concentrations and provides an example of proteome plasticity. The acute addition of $\mathrm{Cd}$ caused more changes in protein response at low $\mathrm{PO}_{4}{ }_{4}^{3-}$ than high $\mathrm{PO}_{4}{ }^{3-}$ conditions, which may indicate a connection between $\mathrm{Cd}$ and $\mathrm{P}$. Comparisons with literature transcriptome analyses of $\mathrm{PO}_{4}{ }^{3-}$ stress in this organism showed similar increases in relative abundance of $\mathrm{PO}_{4}{ }^{3-}$ stress response proteins including PstS (a phosphate binding protein) and an alkaline phosphatase (access of organic phosphate), which shows consistency in the two approaches. One bacterial metallothionein (SmtA) also appeared to be correlated with proteins present under low $\mathrm{PO}_{4}{ }^{3-}$ conditions.

These studies also raised questions about the meaning of toxicity. As discussed in Chapter 2 on page 39, toxicity can be considered the deleterious effects of a substance to an organism. Toxicity itself refers to the degree of being poisonous, or degree of harmful effects produced by a substance in an organism. Toxic effects can range from decreased performance to death. In field experiments described in Chapter 2, toxicity was considered to be decreased performance of bottled phytoplankton assemblages in terms of decreased chlorophyll $a$ concentrations relative to a control treatment. Although the 
phytoplankton assemblages did not die (using chlorophyll $a$ concentrations as a proxy for biomass), they were negatively affected. In laboratory experiments described in Chapter 3 , the decreased performance of cultures exposed to chronic $\mathrm{Cd}$ as evinced by greater than or equal to two-fold differences in protein abundances was observed followed by the earlier death of these cultures. The effect was dose-dependent, with the higher $\mathrm{Cd}$ treatment dying faster than the lower $\mathrm{Cd}$ treatment. Most studies that only focus on growth phase or only measure cell abundances coupled with fluorescence measurements would miss the toxicity of $\mathrm{Cd}$ observed in Chapter 3 . These results support the idea that chronic exposure of organisms to small amounts of a toxin may take time for the deleterious effects to be observed, and that global proteomics may serve as a tool to identify toxic effects.

Overall, this work has yielded many insights into the interactions of $\mathrm{Cd}, \mathrm{Zn}$ and $\mathrm{P}$ and set the stage for future research in the laboratory and in the field. It has shown that $\mathrm{Cd}$ affects many cellular processes and that there are interactions between $\mathrm{Cd}, \mathrm{Zn}$ and $\mathrm{P}$. The global proteomic analyses allowed observation of changes in relative protein abundances among different treatments even when growth rates and fluorescence measurements were similar giving a detailed view of the reactions of cells to changing environmental conditions and suggesting proteome plasticity. Global proteomic methods applied to cyanobacterial and other systems in the future will also be useful for elucidating mechanisms of hormetic response. The relationships of metals to proteins will be vital to understanding the interactions observed between these elements and organisms in the environment. 


\section{Appendix I: Supplementary Data to Chapter 2}

Table I.1: Costa Rica Upwelling Dome station

locations

\begin{tabular}{llll} 
Station & $\begin{array}{c}\text { Latitude } \\
\left({ }^{\circ} \mathrm{N}\right)\end{array}$ & $\begin{array}{c}\text { Longitude } \\
\left({ }^{\circ} \mathrm{W}\right)\end{array}$ & $\begin{array}{c}\text { Local date } \\
{ }^{\circ} 05\end{array}$ \\
\hline 5 & 8.4750 & 89.9969 & July 18 \\
7 & 10.0035 & 90.0026 & July 19 \\
11 & 8.6864 & 87.4922 & July 22 \\
13 & 9.5025 & 92.3287 & July 24 \\
14 & 9.9983 & 96.4955 & July 26 \\
15 & 9.9835 & 96.9808 & July 27 \\
17 & 2.0417 & 97.0512 & July 29 \\
\hline
\end{tabular}

See Figure 2.1.

Table I.2: Station 11 particulate cadmium uptake, cyanobacterial cell numbers and chlorophyll $a$ $\begin{array}{lll}\operatorname{chl} a & \operatorname{chl} a \quad \operatorname{chl} a\end{array}$

Depth $\mathrm{Cd}_{\text {Tot }} \mathrm{Cd}$ Uptake Rate chl $a \quad 2 \mu \mathrm{m}-10 \mu \mathrm{m} \quad>10 \mu \mathrm{m} \quad<2 \mu \mathrm{m}$ Prochlorococcus Synechococcus

\begin{tabular}{|c|c|c|c|c|c|c|c|c|}
\hline$(\mathrm{m})$ & $(\mathrm{pM})$ & $\left(\mathrm{pmol} \mathrm{L} \mathrm{L}^{-1} \mathrm{~d}^{-1}\right)$ & $\left(\mu \mathrm{g} \mathrm{L}^{-1}\right)$ & $\left(\mu \mathrm{g} \mathrm{L}^{-1}\right)$ & $\left(\mu g \mathrm{~L}^{-1}\right)$ & $\left(\mu g \mathrm{~L}^{-1}\right)$ & $\left(\right.$ cells $\left.\mathrm{mL}^{-1}\right)$ & (cells $\mathrm{mL}^{-1}$ ) \\
\hline 8 & 0 & $2.8 \pm 0.14$ & 0.510 & 0.150 & 0.126 & 0.173 & $2.50 \times 10^{5}$ & $3.47 \times 10^{5}$ \\
\hline 15 & 30 & $1.3 \pm 0.09$ & 0.548 & 0.182 & 0.062 & 0.269 & $2.63 \times 10^{5}$ & $3.61 \times 10^{5}$ \\
\hline 30 & 78 & $0.43 \pm 0.02$ & 0.448 & 0.114 & 0.027 & 0.218 & $1.10 \times 10^{5}$ & $1.02 \times 10^{5}$ \\
\hline 50 & 185 & nd & 0.178 & 0.038 & 0.024 & 0.148 & $2.55 \times 10^{4}$ & $5.94 \times 10^{3}$ \\
\hline 80 & 399 & nd & $\mathrm{nm}$ & $\mathrm{nm}$ & $\mathrm{nm}$ & $\mathrm{nm}$ & $4.28 \times 10^{3}$ & $3.96 \times 10^{2}$ \\
\hline 100 & 551 & nd & $\mathrm{nm}$ & $\mathrm{nm}$ & $\mathrm{nm}$ & $\mathrm{nm}$ & 405 & 531 \\
\hline
\end{tabular}

See Figure 2.4. nd = non-detectable, $\mathrm{nm}=$ not measured. 
Table I.3: Station 17 particulate cadmium uptake, cyanobacterial cell numbers and chlorophyll $a$

$$
\operatorname{chl} a \quad \operatorname{chl} a \quad \operatorname{chl} a
$$

Depth $\mathrm{Cd}_{\text {Tot }}$ Cd Uptake Rate chl a $2 \mu \mathrm{m}-10 \mu \mathrm{m}>10 \mu \mathrm{m} \quad<2 \mu \mathrm{m}$ Prochlorococcus Synechococcus

\begin{tabular}{|c|c|c|c|c|c|c|c|c|}
\hline (m) & $(\mathrm{pM})$ & $\left(\mathrm{pmol} \mathrm{L}^{-1} \mathrm{~d}^{-1}\right)$ & $\left(\mu \mathrm{g} \mathrm{L}^{-1}\right)$ & $\left(\mu \mathrm{g} \mathrm{L}^{-1}\right)$ & $\left(\mu \mathrm{g} \mathrm{L}^{-1}\right)$ & $\left(\mu \mathrm{g} \mathrm{L}^{-1}\right)$ & $\left(\right.$ cells $\mathrm{mL}^{-1}$ ) & (cells $\mathrm{mL}^{-1}$ ) \\
\hline 8 & 0 & $1.23 \pm 0.09$ & 0.183 & 0.069 & 0.033 & 0.078 & $1.05 \times 10^{5}$ & $2.45 \times 10^{4}$ \\
\hline 15 & 0 & $1.92 \pm 0.14$ & 0.198 & $0.067^{*}$ & $0.041^{*}$ & $0.092 *$ & $1.15 \times 10^{5}$ & $2.85 \times 10^{4}$ \\
\hline 30 & 66 & $0.96 \pm 0.06$ & $\mathrm{~nm}$ & $0.062 *$ & $0.043^{*}$ & $0.163 *$ & $4.46 \times 10^{4}$ & $3.36 \times 10^{4}$ \\
\hline 80 & 161 & $0.26 \pm 0.02$ & $\mathrm{~nm}$ & 0.013 & 0.003 & 0.036 & $2.37 \times 10^{4}$ & 46 \\
\hline 100 & 267 & nd & nd & $\mathrm{nm}$ & $\mathrm{nm}$ & $\mathrm{nm}$ & $\mathrm{nm}$ & $\mathrm{nm}$ \\
\hline 310 & 317 & $0.40 \pm 0.03$ & $\mathrm{~nm}$ & $\mathrm{~nm}$ & $\mathrm{~nm}$ & $\mathrm{~nm}$ & $\mathrm{~nm}$ & $\mathrm{~nm}$ \\
\hline 350 & $\mathrm{~nm}$ & $0.059 \pm 0.004^{+}$ & $\mathrm{nm}$ & $\mathrm{nm}$ & $\mathrm{nm}$ & $\mathrm{nm}$ & $\mathrm{nm}$ & $\mathrm{nm}$ \\
\hline 400 & 715 & nd & nd & $\mathrm{nm}$ & $\mathrm{nm}$ & $\mathrm{nm}$ & $\mathrm{nm}$ & $\mathrm{nm}$ \\
\hline 460 & 754 & nd & nd & $\mathrm{nm}$ & $\mathrm{nm}$ & $\mathrm{nm}$ & $\mathrm{nm}$ & $\mathrm{nm}$ \\
\hline 650 & 844 & nd & nd & $\mathrm{nm}$ & $\mathrm{nm}$ & $\mathrm{nm}$ & $\mathrm{nm}$ & $\mathrm{nm}$ \\
\hline
\end{tabular}

See Figure 2.5. nd $=$ non-detectable. $\mathrm{nm}=$ not measured. Data marked with an * are values in rows actually measured at 25 and $47 \mathrm{~m}$ depth, respectively. Data marked with an + indicate a $\mathrm{Cd}$ uptake rate calculated without accounting for total dissolved cadmium. Data points plotted in Figure $2.8 \mathrm{f}$ represent the correct depth.

Table I.4: Station 11 Cadmium isotope ratios

\begin{tabular}{lcccccc}
$\begin{array}{c}\text { Depth } \\
(\mathrm{m})\end{array}$ & ${ }^{114} \mathrm{Cd} /{ }^{110} \mathrm{Cd}$ & ${ }^{114} \mathrm{Cd} /{ }^{111} \mathrm{Cd}$ & ${ }^{111} \mathrm{Cd} /{ }^{110} \mathrm{Cd}$ & $\begin{array}{c}\text { Blank } \\
{ }^{114} \mathrm{Cd} /{ }^{110} \mathrm{Cd}\end{array}$ & $\begin{array}{c}\text { Blank } \\
{ }^{114} \mathrm{Cd} /{ }^{11} \mathrm{Cd}\end{array}$ & $\begin{array}{c}\text { Blank } \\
{ }^{111} \mathrm{Cd} /{ }^{10} \mathrm{Cd}\end{array}$ \\
\hline 8 & $0.230 \pm 0.020$ & $1.907 \pm 0.160$ & $0.120 \pm 0.011$ & 2.139 & 2.146 & 0.997 \\
15 & $0.424 \pm 0.058$ & $1.947 \pm 0.237$ & $0.218 \pm 0.026$ & 2.244 & 2.140 & 1.049 \\
30 & $0.675 \pm 0.068$ & $2.095 \pm 0.235$ & $0.322 \pm 0.035$ & 2.349 & 2.235 & 1.051 \\
50 & $1.163 \pm 0.128$ & $1.501 \pm 0.191$ & $0.775 \pm 0.069$ & 2.369 & 2.313 & 1.024 \\
80 & $2.188 \pm 0.213$ & $1.372 \pm 0.210$ & $1.596 \pm 0.103$ & 2.634 & 2.414 & 1.091 \\
100 & nd & nd & $3.715 \pm 0.120$ & 2.431 & 2.038 & 1.193 \\
\hline
\end{tabular}

nd $=$ non-detectable. See Figure 2.6. $*=$ had 0.088 as error

Table I.5: Station 11 Time-course experiment isotope ratios

Time

\begin{tabular}{llll} 
(hr) & ${ }^{114} \mathrm{Cd} /{ }^{110} \mathrm{Cd}$ & ${ }^{114} \mathrm{Cd} /{ }^{111} \mathrm{Cd}$ & ${ }^{111} \mathrm{Cd} /{ }^{110} \mathrm{Cd}$ \\
\hline 3 & $0.310 \pm 0.031$ & $2.078 \pm 0.213$ & $0.149 \pm 0.013$ \\
6 & $0.288 \pm 0.034$ & $2.092 \pm 0.281$ & $0.138 \pm 0.015$ \\
24 & $0.110 \pm 0.011$ & $1.778 \pm 0.169$ & $0.062 \pm 0.005$ \\
30 & $0.090 \pm 0.009$ & $1.629 \pm 0.151$ & $0.055 \pm 0.005$ \\
\hline
\end{tabular}

See Figure 2.7. 
Table I.6: Time-course experiment

\begin{tabular}{lll} 
Station & $\begin{array}{c}\text { Time } \\
\text { (days) }\end{array}$ & $\begin{array}{c}{ }^{110} \mathrm{Cd} \text { Uptake Rate } \\
\left(\mathrm{pmol} \mathrm{L} \mathrm{d}^{-1}\right)\end{array}$ \\
\hline 5 & 0.125 & 0.97 \\
5 & 1.000 & 0.47 \\
5 & 2.000 & 1.7 \\
7 & 0.125 & 3.36 \\
7 & 0.250 & 3.54 \\
7 & 1.000 & 6.33 \\
7 & 2.000 & 10.86 \\
11 & 0.125 & 2.3 \\
11 & 0.250 & 2.6 \\
11 & 1.000 & 7.5 \\
11 & 1.250 & 5.5 \\
13 & 0.125 & 4.64 \\
13 & 0.250 & 5.13 \\
13 & 0.500 & 2.56 \\
13 & 1.000 & 12.2 \\
15 & 0.250 & 0.06 \\
15 & 0.500 & 0.16 \\
15 & 0.750 & 0.14 \\
15 & 1.000 & 0.27 \\
17 & 0.125 & 0.72 \\
17 & 0.250 & 0.69 \\
17 & 0.542 & 1.84 \\
17 & 1.000 & 2.9 \\
\hline
\end{tabular}

See Figure 2.8. Note that these data are not corrected for preexisting particulate cadmium. 


\section{Appendix II: Supplementary Data to Chapter 3}

Table II.1: WH5701 proteins during early stationary phase (T2) that are more abundant in the $\mathrm{Cd}^{2+}$ treatments than the control by $\geq$ two-fold.

\begin{tabular}{cllcc}
$\begin{array}{c}\text { WH5701 } \\
\text { ID }\end{array}$ & Function & Protein & $\begin{array}{c}4.4 \mathrm{pM} \mathrm{Cd}^{2+} \text { abundance } \\
\text { relative to control }\end{array}$ & $\begin{array}{c}44 \mathrm{pM} \mathrm{Cd}^{2+} \text { abundance } \\
\text { relative to control }\end{array}$ \\
\hline 05830 & $\mathrm{U}, \mathrm{GI}$ & putative ribonuclease D & +3.4 & +4.5 \\
03624 & $\mathrm{M}$ & GDP-mannose pyrophosphorylase & +1.9 & +3.9 \\
09149 & $\mathrm{C}$ & malate oxidoreductase & +1.4 & +2.5 \\
15471 & $\mathrm{C}$ & ribose 5-phosphate isomerase & +2.3 & +2.3 \\
15156 & $\mathrm{Ukn}$ & hypothetical protein & +2.6 & +2.2 \\
01855 & $\mathrm{Ukn}$ & hypothetical protein & +2.5 & +2.2 \\
10470 & En,ABC & extracellular solute-binding protein, & & +1.4 \\
& & family 3 & +4.1 & +1.3 \\
04880 & $\mathrm{Ukn}$ & hypothetical protein & +2.2 & +1.3 \\
15186 & $\mathrm{M}$ & putative aminopeptidase P & +2.3 & +1.9 \\
02904 & $\mathrm{Ukn}$ & hypothetical protein & +2.1 & +1.7 \\
03504 & $\mathrm{M}, \mathrm{Cb}, \mathrm{N}$ & formamidase & +2.1 & \\
\hline
\end{tabular}

Arranged in highest to lowest fold change, $44 \mathrm{pM} \mathrm{Cd}^{2+}$, then $4.4 \mathrm{pM} \mathrm{Cd}^{2+} .+=$ fold greater than control, - $=$ fold less than control, $\mathrm{U}=$ unclassified, $\mathrm{GI}=$ genetic information processing, $\mathrm{M}=$ metabolism, $\mathrm{C}=\mathrm{CO}_{2}$ fixation, $\mathrm{Ukn}=$ unknown, $\mathrm{En}=$ environmental sensing, $\mathrm{ABC}=$ membrane transport $\mathrm{ABC}$ type, $\mathrm{Cb}=$ carbohydrate metabolism, $\mathrm{N}=$ nitrogen 
Table II.2: WH5701 proteins during early stationary phase (T2) that are two-fold or more less abundant in the $\mathrm{Cd}^{2+}$ treatments than the control.

WH5701 KEGG

ID Function
$4.4 \mathrm{pM} \mathrm{Cd}^{2+}$ abundance relative to control
$44 \mathrm{pM} \mathrm{Cd}^{2+}$ abundance relative to control

\begin{tabular}{|c|c|c|c|c|}
\hline 01585 & PS & photosystem I subunit VII & -3.7 & -20 \\
\hline 05480 & PS & photosystem I core protein (psaB) & -11.2 & -16 \\
\hline 11384 & Chl & photochlorophyllide oxidoreductase & -5.9 & -8.3 \\
\hline 08839 & $\mathrm{M}, \mathrm{Cb}$ & acetate--CoA ligase & -5.9 & -8.3 \\
\hline 14421 & PS & photosynthetic II protein (psbC) & -6.7 & -6.7 \\
\hline 06000 & PS & $\begin{array}{l}\text { photosystem II chlorphyll binding } \\
\text { protein }\end{array}$ & -4.6 & -5.6 \\
\hline 04930 & GI,T & $\begin{array}{l}\text { aspartyl/glutamyl-tRNA amidotransferase } \\
\text { subunit B }\end{array}$ & -4.9 & -5.5 \\
\hline 15241 & PS & ATP synthase subunit A & -4.2 & -5.0 \\
\hline 08459 & GI,T & $\begin{array}{l}\text { glutamyl-tRNA (Gln) amidotransferase } \\
\text { subunit A }\end{array}$ & -4.4 & -4.8 \\
\hline 04715 & $\mathrm{~N}, \mathrm{ABC}$ & $\begin{array}{l}\text { ABC-type nitrate/nitrite transport } \\
\text { system substrate-binding protein }\end{array}$ & -4.0 & -5.8 \\
\hline 02614 & $\mathrm{P}, \mathrm{ABC}$ & $\begin{array}{l}\mathrm{ABC} \text { transporter, substrate binding } \\
\text { protein, phosphate }\end{array}$ & -4.4 & -3.8 \\
\hline 04620 & St,L & arylsulfatase & -1.2 & -3.7 \\
\hline 06176 & PS & photosystem I reaction center subunit IV & -2.0 & -3.6 \\
\hline 15121 & PS & ATP synthase subunit B & -2.7 & -3.5 \\
\hline 08944 & $\mathrm{M}, \mathrm{N}, \mathrm{A}, \mathrm{S}$ & glutamine synthethase type III & -1.6 & -3.3 \\
\hline 01470 & $\mathrm{M}, \mathrm{A}, \mathrm{V}$ & serine hydroxymethyltransferase & -2.0 & -3.3 \\
\hline 05815 & Chl & coproporphyrinogen III oxidase & -2.7 & -2.9 \\
\hline 05565 & GI,T & 30 S ribosomal protein S11 & -2.5 & -2.7 \\
\hline 12533 & Ch1 & uroporphyrinogen decarboxylase & -3.4 & -2.6 \\
\hline 15851 & PS & $\begin{array}{l}\text { ferredoxin-thioredoxin reductase } \\
\text { catalytic chain }\end{array}$ & -1.0 & -2.5 \\
\hline 05050 & GI,T & $\begin{array}{l}\text { transcription antitermination protein } \\
\text { NusG }\end{array}$ & -2.7 & -2.4 \\
\hline 15626 & $\mathrm{U}$ & putative membrane protein & -1.1 & -2.2 \\
\hline 07386 & $\mathrm{M}, \mathrm{Nu}, \mathrm{A}$ & possible cytosine deaminase & +1.1 & -2.2 \\
\hline 13850 & Ukn & hypothetical protein & -1.4 & -2.2 \\
\hline 12538 & $\mathrm{M}, \mathrm{Cb}$ & glycogen branching enzyme & -1.6 & -2.2 \\
\hline 01005 & $\mathrm{M}, \mathrm{N}$ & $\begin{array}{l}\text { ferredoxin-dependent glutamate } \\
\text { synthase, Fd-GOGAT }\end{array}$ & +1.1 & -2.0 \\
\hline 05060 & GI,T & 50S ribosomal protein L1 & -2.0 & -2.0 \\
\hline 05910 & PS & phycobilisome linker polypeptide & -1.1 & -2.0 \\
\hline 05610 & GI,T & $30 \mathrm{~S}$ ribosomal protein $\mathrm{S} 8$ & -6.0 & -2.0 \\
\hline 15451 & U,GI & $\begin{array}{l}\text { DNA-directed RNA polymerase } \\
\text { beta subunit }\end{array}$ & -2.6 & -2.0 \\
\hline 05590 & GI,T & 50S ribosomal protein L15 & -2.6 & -2.0 \\
\hline 01150 & PS & photosystem Il Mn-stabilizing protein & -2.5 & -1.7 \\
\hline
\end{tabular}


Table II.2 (continued, page 2 of 2):

\begin{tabular}{|c|c|c|c|c|}
\hline $\begin{array}{l}\text { WH5701 } \\
\text { ID }\end{array}$ & $\begin{array}{l}\text { KEGG } \\
\text { Function }\end{array}$ & Protein & $\begin{array}{l}\mathrm{pM} \mathrm{Cd}^{2+} \text { abundance } \\
\text { relative to control }\end{array}$ & $\begin{array}{l}44 \mathrm{pM} \mathrm{Cd}^{2+} \text { abundance } \\
\text { relative to control }\end{array}$ \\
\hline 05600 & GI,T & 50S ribosomal protein L18 & -2.3 & -1.2 \\
\hline \multirow[t]{2}{*}{06556} & $\mathrm{M}, \mathrm{N}, \mathrm{GI}$ & polyribonucleotide & & \\
\hline & & nucleotidyltransferase & -2.1 & +1.2 \\
\hline 05570 & GI,T & 30S ribosomal protein $\mathrm{S} 13$ & -2.1 & -1.6 \\
\hline 10210 & PS & ferredoxin--NADP reductase (FNR) & -2.0 & -1.9 \\
\hline
\end{tabular}

Arranged in highest to lowest fold change, $44 \mathrm{pM} \mathrm{Cd}^{2+}$, then $4.4 \mathrm{pM} \mathrm{Cd}^{2+} .+=$ fold greater than control, $-=$ fold less than control, $\mathrm{PS}=$ photosynthesis, $\mathrm{Chl}=$ chlorophyll biosynthesis, $\mathrm{M}=$ metabolism, $\mathrm{Cb}=$ carbohydrate metabolism, $\mathrm{GI}=$ genetic information processing, $\mathrm{T}=$ translation, $\mathrm{N}=$ nitrogen metabolism, $\mathrm{ABC}=$ membrane transport - $\mathrm{ABC}$ type, $\mathrm{P}=$ phosphorus metabolism, $\mathrm{St}=$ steroid hormone synthesis, $\mathrm{L}=$ lipid biosynthesis, $\mathrm{A}=$ amino acid metabolism, $\mathrm{S}=$ sulfur metabolism, $\mathrm{V}=$ vitamin metabolism, $\mathrm{U}=$ unclassified, $\mathrm{Nu}=$ nucleic acid metabolism, Ukn = unknown 
Table II.3: WH5701 proteins during mid-stationary phase (T3) that are more abundant in the $\mathrm{Cd}^{2+}$ treatments compared to the control by $\geq$ two-fold.

\begin{tabular}{|c|c|c|c|c|}
\hline $\begin{array}{l}\text { WH5701 } \\
\text { ID }\end{array}$ & $\begin{array}{l}\text { KEGG } \\
\text { Function }\end{array}$ & $\begin{array}{r}4.4 \mathrm{pM} \\
\text { rela } \\
\end{array}$ & $\begin{array}{l}\mathrm{M} \mathrm{Cd}^{2+} \text { abundance } \\
\text { lative to control }\end{array}$ & $\begin{array}{l}44 \mathrm{pM} \mathrm{Cd}^{2+} \text { abundance } \\
\text { relative to control } \\
\end{array}$ \\
\hline 02239 & $\mathrm{St}, \mathrm{L}$ & putative arylsulfatase & +5.9 & +6.2 \\
\hline 03654 & $\mathrm{M}$ & $\begin{array}{l}\text { glycogen/starch/alpha-gulcan } \\
\text { phosphorylase }\end{array}$ & +4.7 & +6.2 \\
\hline 15451 & U,GI & $\begin{array}{l}\text { DNA-directed RNA polymerase beta } \\
\text { subunit }\end{array}$ & +2.6 & +4.2 \\
\hline 15441 & U,GI & $\begin{array}{l}\text { DNA-directed RNA polymerase beta' } \\
\text { subunit }\end{array}$ & +2.6 & +4.1 \\
\hline 03604 & $\mathrm{M}$ & $\begin{array}{l}\text { glycogen/starch/alpha-gulcan } \\
\text { phosphorylase }\end{array}$ & +6.0 & +4.1 \\
\hline 11344 & $\mathrm{M}, \mathrm{C}$ & $\begin{array}{l}\text { ribulose } 1,5 \text { bisphosphate carboxylase } \\
\text { small chain }\end{array}$ & +3.7 & +4.0 \\
\hline 01860 & Ukn & hypothetical protein & +2.2 & +3.9 \\
\hline 11349 & $\mathrm{U}, \mathrm{GI}$ & methionine sulfoxide reductase $\mathrm{A}$ & +2.8 & +3.6 \\
\hline 07844 & Ukn & hypothetical protein & +2.6 & +3.6 \\
\hline 05030 & M & enolase & +2.8 & +3.5 \\
\hline 10470 & En, ABC & $\begin{array}{l}\text { extracellular solute-binding protein } \\
\text { family } 3\end{array}$ & +1.4 & +3.4 \\
\hline 06556 & $\mathrm{M}, \mathrm{Nu}, \mathrm{GI}$ & $\begin{array}{l}\text { polyribonucleotide nucleotidyl- } \\
\text { transferase }\end{array}$ & +1.7 & +3.3 \\
\hline 03504 & $\mathrm{M}, \mathrm{Cb}, \mathrm{N}$ & formamidase & +3.5 & +3.1 \\
\hline 13100 & M,A,Ly & diaminopimelate epimerase & +3.8 & +2.9 \\
\hline 04700 & $\mathrm{~N}$ & ferredoxin-nitrite reductase & +2.7 & +2.9 \\
\hline 05815 & $\mathrm{M}, \mathrm{Chl}$ & coproporphyrinogen III oxidase & +3.3 & +2.5 \\
\hline 01585 & PS & photosystem I subunit VII & +1.3 & +2.5 \\
\hline 11924 & $\mathrm{U}, \mathrm{T}$ & ribosome releasing factor & +2.1 & +2.4 \\
\hline 12134 & $\begin{array}{l}\text { En,ABC } \\
\text { U.Fe }\end{array}$ & $\begin{array}{l}\text { putative iron } \mathrm{ABC} \text { transporter } \\
\text { substate binding protein }\end{array}$ & +1.7 & +2.2 \\
\hline 13035 & $\mathrm{M}, \mathrm{A}$ & $\begin{array}{l}\text { branched-chain amno acid } \\
\text { aminotransferase }\end{array}$ & +1.9 & +2.1 \\
\hline 11339 & $\mathrm{C}$ & carboxysome shell protein & +1.0 & +2.1 \\
\hline 01855 & Ukn & hypothetical protein & -1.1 & +2.0 \\
\hline 08744 & 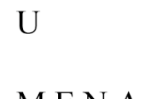 & $\begin{array}{l}\text { zinc-containing alcohol } \\
\text { dehydrogenase superfamily }\end{array}$ & +5.5 & +4.5 \\
\hline 13575 & $\begin{array}{l}\text { M,E,N,A } \\
\text { En }\end{array}$ & $\begin{array}{l}\text { glutamine synthetase, glutamate } \\
\text { ammonia ligase }\end{array}$ & +4.5 & +5.8 \\
\hline 14556 & $\mathrm{M}, \mathrm{Nu}, \mathrm{V}$ & $\begin{array}{l}\text { stationary-phase survival protein } \\
\text { SurE }\end{array}$ & +4.1 & +2.6 \\
\hline 15671 & U,GI & methionine sulfoxide reductase $\mathrm{B}$ & +2.8 & +2.1 \\
\hline 12533 & $\mathrm{M}, \mathrm{Chl}$ & uroporphyrinogen decarboxylase & +2.6 & +1.8 \\
\hline 12538 & $\mathrm{M}, \mathrm{Cb}$ & glycogen branching enzyme & +2.5 & +1.8 \\
\hline 13175 & $\begin{array}{l}\text { M, A,Cy, } \\
\text { Met }\end{array}$ & $\begin{array}{l}\text { 5'-methylthioadenosine } \\
\text { phosphorylase }\end{array}$ & +2.3 & +1.6 \\
\hline
\end{tabular}

Arranged in highest to lowest fold change, $44 \mathrm{pM} \mathrm{Cd}^{2+}$, then $4.4 \mathrm{pM} \mathrm{Cd}^{2+} .+=$ fold greater than control, $-=$ fold less than control, $\mathrm{St}=$ steroid hormone synthesis, $\mathrm{L}=$ lipid biosynthesis, $\mathrm{M}=$ metabolism, $\mathrm{U}=$ unclassified, $\mathrm{GI}=$ genetic information processing, $\mathrm{C}=\mathrm{CO}_{2}$ fixation, $\mathrm{Ukn}=$ unknown, $\mathrm{En}=$ environmental sensing, $\mathrm{ABC}=$ membrane transport $\mathrm{ABC}$ type, $\mathrm{Nu}=$ nucleic acid metabolsim, $\mathrm{Cb}=$ carbohydrate metabolism, $\mathrm{N}=$ nitrogen, $\mathrm{A}=$ amino acid metabolism, $\mathrm{Ly}=$ lysine synthesis, $\mathrm{Chl}=$ chlorophyll biosynthesis, $\mathrm{PS}=$ photosynthesis, $\mathrm{T}=$ translation, $\mathrm{V}=$ vitamin metabolism, $\mathrm{Cy}=$ cysteine metabolism, Met $=$ methionine synthesis 
Table II.4: WH5701 proteins during mid-stationary phase (T3) that are two-fold or more less abundant in the $\mathrm{Cd}^{2+}$ than the control treatments.

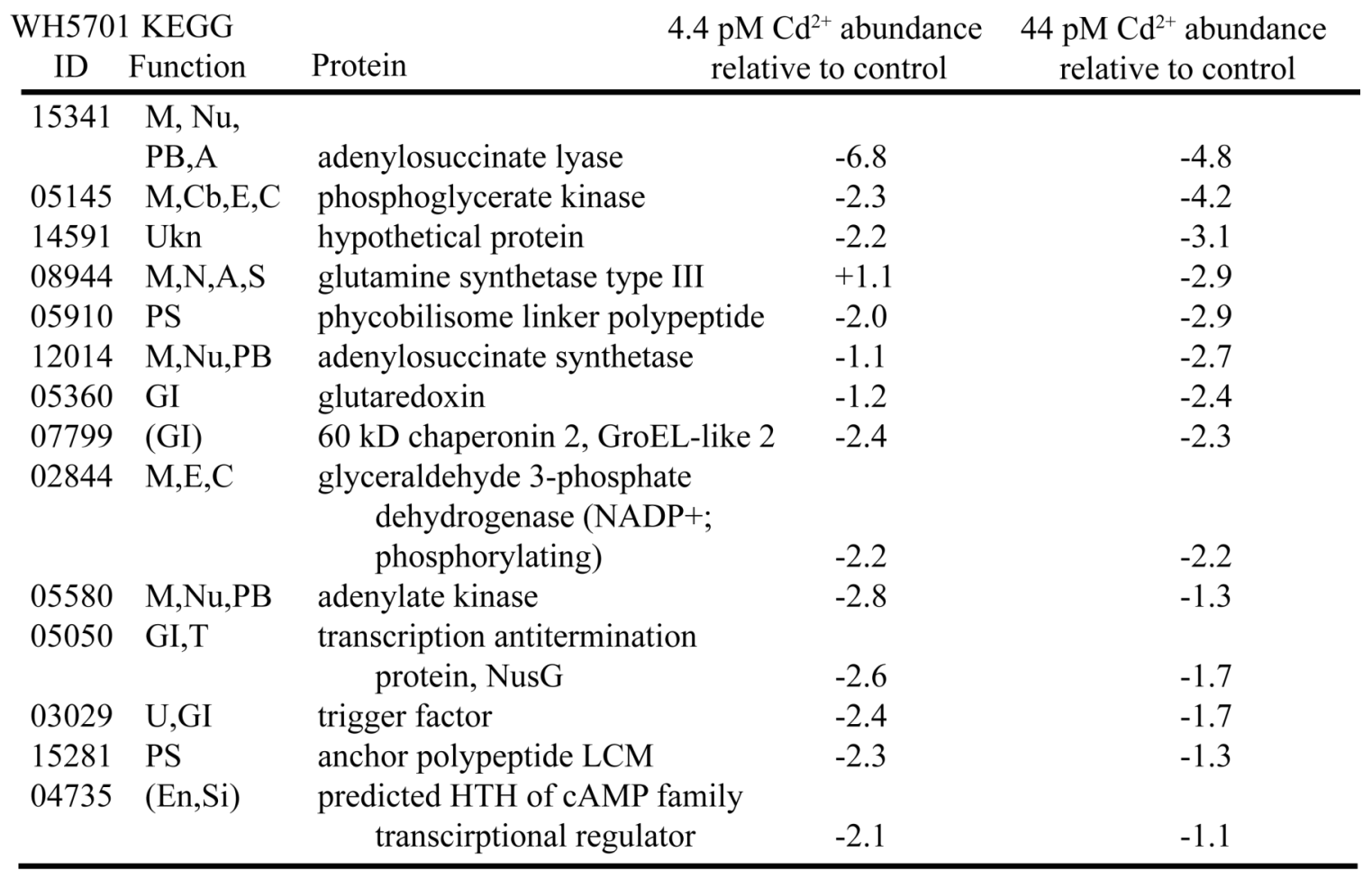

Arranged in highest to lowest fold change: $44 \mathrm{pM} \mathrm{Cd}^{2+}$ then $4.4 \mathrm{pM} \mathrm{Cd}^{2+} .+=$ fold greater than control, $-=$ fold less than control, $\mathrm{PB}=$ purine biosynthesis, $\mathrm{M}=$ metabolism, $\mathrm{E}=$ energy metabolism, $\mathrm{C}=\mathrm{CO}_{2}$ fixation, Ukn = unknown, $\mathrm{N}=$ nitrogen, $\mathrm{A}=$ amino acid metabolism, $\mathrm{S}=$ sulfur metabolism, $\mathrm{PS}=$ photosynthesis, $\mathrm{Nu}=$ nucleic acid metabolsim, $\mathrm{GI}=$ genetic information processing, $\mathrm{T}=$ translation, $\mathrm{U}=$ unclassified, $\mathrm{En}=$ environmental sensing, $\mathrm{Si}$ = signaling. 
Table II.5: WH5701 proteins during late stationary phase (T4) that are more abundant in at least one of the $\mathrm{Cd}^{2+}$ treatments compared to the control by $\geq$ two-fold.

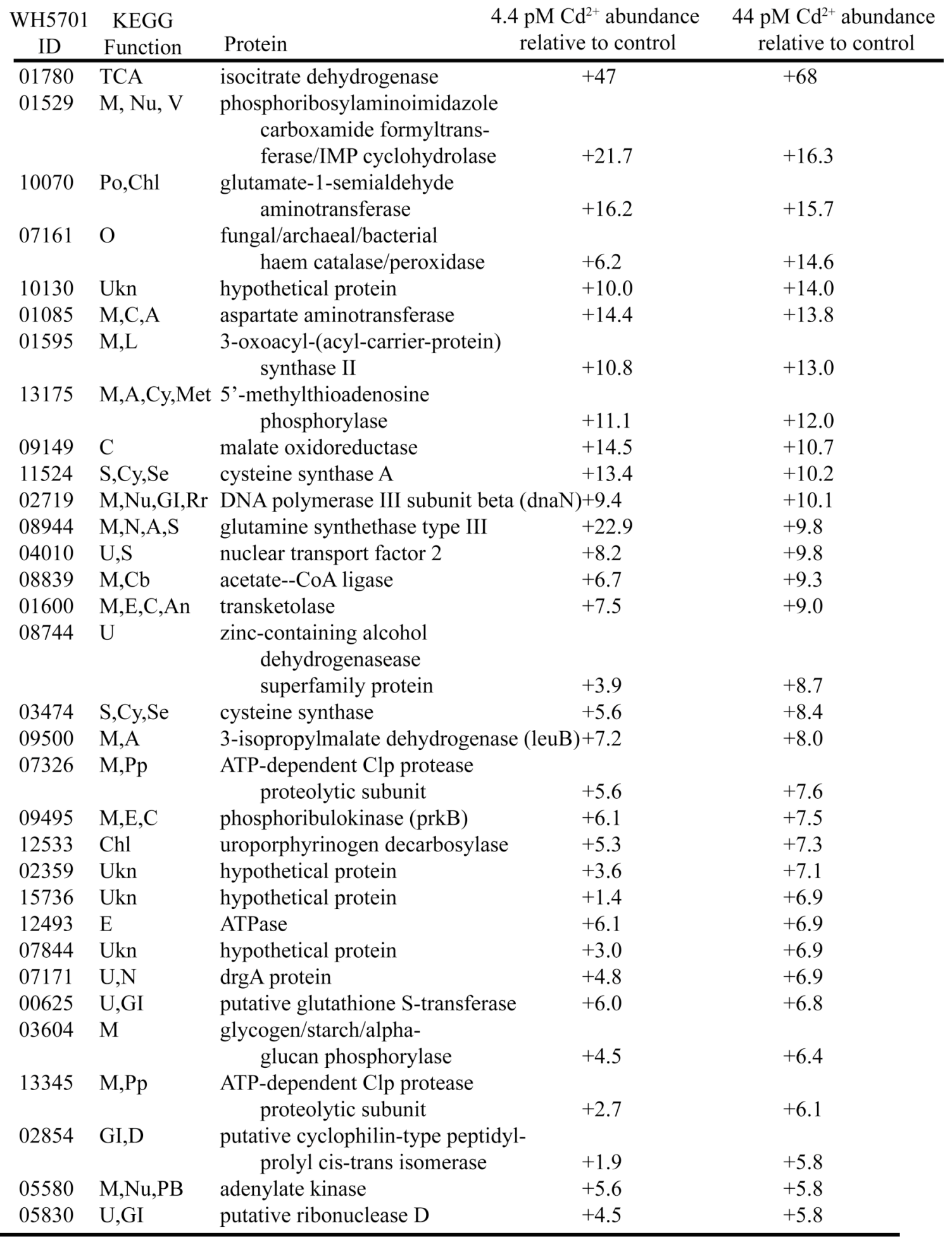


Table II.5 (continued page 2 of 3 )

\begin{tabular}{|c|c|c|c|c|}
\hline $\begin{array}{l}\text { WH5701 } \\
\text { ID }\end{array}$ & $\begin{array}{l}\text { KEGG } \\
\text { Function }\end{array}$ & $\begin{array}{r}4.4 \mathrm{pM} \mathrm{C} \\
\text { relativ }\end{array}$ & $\begin{array}{l}\mathrm{d}^{2+} \text { abundance } \\
\text { ve to control }\end{array}$ & $\begin{array}{l}44 \mathrm{pM} \mathrm{Cd}^{2+} \text { abundance } \\
\text { relative to control }\end{array}$ \\
\hline 15626 & $\mathrm{U}$ & putative membrane protein & +5.8 & +5.5 \\
\hline 09635 & U,GI & putative glutathione S-transferase & +3.3 & +5.4 \\
\hline 04700 & PS & ferredoxin--NADP reductase (FNR) & +2.5 & +5.2 \\
\hline 15671 & $\mathrm{U}$ & methionine sulfoxide reductase B & +2.5 & +5.2 \\
\hline 08459 & GI,T & $\begin{array}{c}\text { glutamyl-tRNA (Gln) amido- } \\
\text { transferase subunit A }\end{array}$ & +58 & +50 \\
\hline \multirow[t]{2}{*}{10110} & $\mathrm{M}, \mathrm{A}, \mathrm{Nu}$ & carbamoyl-phosphate synthase & & \\
\hline & & large subunit & +4.5 & +4.2 \\
\hline 15926 & $\mathrm{M}, \mathrm{Cb}, \mathrm{Nu}$ & phosphoglucomutase (pgm) & +2.4 & +4.1 \\
\hline 05130 & ukn & hypothetical protein & +2.4 & +3.9 \\
\hline \multirow[t]{2}{*}{08064} & PB & inositol-5-monophosphate & & \\
\hline & & dehydrogenase & +4.1 & +3.9 \\
\hline 01205 & $\mathrm{M}, \mathrm{E}, \mathrm{C}, \mathrm{Cb}$ & phosphoenolpyruvate carboxylase (ppc) & +3.2 & +3.7 \\
\hline 14781 & ukn & hypothetical protein & +2.8 & +3.6 \\
\hline 07386 & $\mathrm{M}, \mathrm{Nu}, \mathrm{A}$ & possible cytosine deaminase & -1.4 & +3.6 \\
\hline 09740 & ukn & hypothetical protein & +2.6 & +3.5 \\
\hline 00960 & $\mathrm{M}, \mathrm{A}$ & tryptophan synthase subunit beta & +1.6 & +3.5 \\
\hline \multirow[t]{2}{*}{15771} & GI,T & translation initiation factor IF-2B & & \\
\hline & & subunit alpha & +2.8 & +3.3 \\
\hline 15141 & M,Pt & penicillin-binding protein (pbp) & +1.1 & +3.2 \\
\hline \multirow[t]{2}{*}{13170} & GI,D & cyclophilin-type peptidyl- & & \\
\hline & & prolyl cis-trans isomerase & +4.0 & +3.0 \\
\hline 10210 & PS & ferredoxin-NADP reductase (FNR) & +2.6 & +2.8 \\
\hline \multirow[t]{2}{*}{07316} & $\mathrm{M}, \mathrm{A}, \mathrm{V}$ & acetohydroxy acid & & \\
\hline & & isomeroreductase & +2.1 & +2.8 \\
\hline 12029 & ukn & hypothetical protein & +1.9 & +2.8 \\
\hline 10235 & ukn & hypothetical protein & +3.0 & +2.8 \\
\hline 04930 & GI,T & $\begin{array}{l}\text { aspartyl/glutamyl-tRNA amido- } \\
\text { transferase subunit B }\end{array}$ & +2.6 & +2.6 \\
\hline 11384 & chl & protochlorophyllide oxidoreductase & +2.1 & +2.6 \\
\hline 15291 & PS & allophycocyanin, beta subunit & +2.4 & +2.5 \\
\hline 05900 & PS & phycocyanin beta subunit & +2.6 & +2.5 \\
\hline 09875 & ukn & hypothetical protein & +3.5 & +2.4 \\
\hline 04620 & $\mathrm{St}, \mathrm{L}$ & arylsulfatase & +2.2 & +2.4 \\
\hline 15286 & PS & phycocyanin alpha chain & +2.2 & +2.4 \\
\hline 10105 & ukn & hypothetical protein & +2.2 & +2.3 \\
\hline 10599 & PS & phycocyanin beta subunit & +2.5 & +2.3 \\
\hline 09835 & ukn & hypothetical protein & +2.1 & +2.3 \\
\hline 12958 & PS & allophycocyanin alpha-B chain & +1.6 & +2.2 \\
\hline 05895 & PS & phycocyanin, alpha subunit & +2.1 & +2.1 \\
\hline \multirow[t]{2}{*}{13580} & PS & $\begin{array}{l}\text { phycobilisome core component- } \\
\text { allophycocyanin beta- }\end{array}$ & & \\
\hline & & 18 subunit & +1.8 & +2.1 \\
\hline 01470 & $\mathrm{M}, \mathrm{A}, \mathrm{V}$ & serine hydroxymethyltransferase & +1.4 & +2.1 \\
\hline 15186 & $\mathrm{M}$ & putative aminopeptidase $\mathrm{P}$ & +20 & +12 \\
\hline
\end{tabular}


Table II.5 (continued page 3 of 3)

\begin{tabular}{|c|c|c|c|c|}
\hline $\begin{array}{l}\text { WH5701 } \\
\text { ID }\end{array}$ & $\begin{array}{l}\text { KEGG } \\
\text { Function }\end{array}$ & Protein & $\begin{array}{c}4.4 \mathrm{pM} \mathrm{Cd}^{2+} \text { abundance } \\
\text { relative to control }\end{array}$ & $\begin{array}{l}44 \mathrm{pM} \mathrm{Cd}^{2+} \text { abundance } \\
\text { relative to control }\end{array}$ \\
\hline 03881 & M,A,GI & aspartyl-tRNA synthetase & +17.8 & +9.9 \\
\hline 01855 & ukn & hypothetical protein & +15.2 & +9.6 \\
\hline 12593 & M & putative oligopeptidase $\mathrm{A}$ & +6.3 & +4.7 \\
\hline 14991 & ukn & hypothetical protein & +5.2 & +2.7 \\
\hline 08464 & GI,T & $\begin{array}{c}\text { glutamyl-tRNA (Gln) amido- } \\
\text { transferase A subunit }\end{array}$ & +5.0 & +1.8 \\
\hline 13795 & ukn & hypothetical protein & +4.4 & -1.1 \\
\hline 13335 & $\mathrm{D}$ & $\begin{array}{l}\text { ATP-dependent protease-like } \\
\text { protein }(\mathrm{ftsH})\end{array}$ & +2.5 & +2.0 \\
\hline 15541 & ukn & hypothetical protein & +2.3 & +1.2 \\
\hline
\end{tabular}

Arranged in highest to lowest fold change, $44 \mathrm{pM} \mathrm{Cd}^{2+}$ followed by $4.4 \mathrm{pM} \mathrm{Cd}^{2+} .+=$ fold greater than control, - = fold less than control, TCA = TCA cycle, $\mathrm{M}=$ metabolism, $\mathrm{Nu}=$ nucleic acid metabolism, $\mathrm{V}=$ vitamin metabolism, $\mathrm{Po}=$ porphyrin biosynthesis, $\mathrm{chl}=$ chlorophyll biosynthesis, $\mathrm{O}=$ oxidiave stress, $\mathrm{ukn}=$ unknown, $\mathrm{C}=\mathrm{CO}_{2}$ fixation, $\mathrm{A}=$ amino acid metabolism, $\mathrm{L}=$ lipid biosynthesis, $\mathrm{Cy}=$ cysteine metabolism, $\mathrm{Met}=$ methionine synthesis, $\mathrm{S}=$ sulfur metabolism, $\mathrm{Se}=$ selenoaminoacid synthesis, $\mathrm{GI}=$ genetic information processing, $\mathrm{Rr}=$ replication and repair, $\mathrm{N}=$ nitrogen metabolism, $\mathrm{U}=$ unclassified, $\mathrm{Cb}=$ carbohydrate metabolism, $\mathrm{E}=$ energy metabolism, $\mathrm{An}=$ ansamycin metabolism, $\mathrm{Pp}=$ peptidase, $\mathrm{D}=$ cell division, $\mathrm{PS}=$ photosynthesis, $\mathrm{PB}=$ purine biosynthesis, $\mathrm{T}=$ translation, $\mathrm{Pt}=$ peptidoglycan biosynthesis, $\mathrm{St}=$ steroid hormone synthesis. 
Table II.6: WH5701 proteins during late stationary phase (T4) that are two-fold or more less abundant in at least one of the $\mathrm{Cd}^{2+}$ treatments compared to the control.

\begin{tabular}{|c|c|c|c|c|}
\hline $\begin{array}{l}\text { WH570 } \\
\text { ID }\end{array}$ & $\begin{array}{l}1 \text { KEGG } \\
\text { Function }\end{array}$ & $\begin{array}{r}4.4 \mathrm{pM} \\
\text { relat }\end{array}$ & $\begin{array}{l}\mathrm{Cd}^{2+} \text { abundance } \\
\text { ive to control }\end{array}$ & $\begin{array}{l}44 \mathrm{pM} \mathrm{Cd}^{2+} \text { abundance } \\
\text { relative to control }\end{array}$ \\
\hline 11354 & $\mathrm{C}$ & carboxysome shell peptide & -13.4 & -14.2 \\
\hline 13075 & Ukn & hypothetical protein & -9.0 & -14.1 \\
\hline 15236 & PS & ATP synthase subunit $\mathrm{C}$ & -13.2 & -13.3 \\
\hline 15241 & PS & ATP synthase subunit A & -11.9 & -10.6 \\
\hline 15886 & Ukn & hypothetical protein & -7.1 & -9.7 \\
\hline 11349 & $\mathrm{U}$ & methionine sulfoxide reductase $\mathrm{A}$ & -13.3 & -9.5 \\
\hline 00710 & $\mathrm{U}, \mathrm{Om}$ & possible porin (som) & -8.7 & -8.7 \\
\hline 11319 & $\mathrm{C}$ & $\begin{array}{l}\text { possible carbon dioxide concentrating } \\
\text { mechanism protein }(\mathrm{CcmK})\end{array}$ & -8.0 & -8.5 \\
\hline 11919 & $\mathrm{M}, \mathrm{Nu}$ & uridylate kinase (pyrH) & -3.3 & -8.4 \\
\hline 01585 & PS & $\begin{array}{l}\text { photosystem I reaction center } \\
\text { subunit VII }\end{array}$ & -15.6 & -7.8 \\
\hline 02239 & St, L & putative arylsulfatase & -17.8 & -7.3 \\
\hline 11339 & $\mathrm{C}$ & carboxysome shell protein & -6.3 & -7.2 \\
\hline 08594 & Ukn & hypothetical protein & -1.3 & -7.1 \\
\hline 14966 & GI,T & 50S ribosomal protein $\mathrm{L} 27$ & -10.1 & -6.6 \\
\hline 00585 & Ukn & hypothetical protein & -2.0 & -6.3 \\
\hline 13035 & BA & $\begin{array}{l}\text { branched-chain amino acid } \\
\text { aminotransferase }\end{array}$ & -10.9 & -5.5 \\
\hline 07426 & M & dihydrolipoamide dehydrogenase & -5.3 & -5.4 \\
\hline 15591 & Chl & $\begin{array}{l}\text { delta-aminolevuliic acid dehydratase } \\
\text { (hemB) }\end{array}$ & -7.2 & -5.1 \\
\hline 15121 & PS & ATP synthase subunit B & -8.0 & -5.1 \\
\hline 05655 & GI,T & 30S ribosomal protein $\mathrm{S} 19$ & -7.6 & -5.1 \\
\hline $\begin{array}{l}09520 \\
05215\end{array}$ & Ukn & $\begin{array}{l}\text { hypothetical protein } \\
\text { nicotinate-nucleotide }\end{array}$ & -4.9 & -5.0 \\
\hline & & pyrophosphatase & -5.0 & -4.9 \\
\hline 09565 & Ukn & hypothetical protein & -8.2 & -4.8 \\
\hline 06176 & PS & $\begin{array}{l}\text { photosystem I reaction center } \\
\text { subunit IV }\end{array}$ & -5.3 & -4.5 \\
\hline 00820 & U,GI & $\begin{array}{l}\text { putative RNA-binding protein } \\
\text { (RRM domain) }\end{array}$ & -3.2 & -4.2 \\
\hline 13585 & M,E,A & $\begin{array}{l}\text { serine:pyruvate/alanine: glyoxylate } \\
\text { aminotransferase (spt,agt) }\end{array}$ & -5.3 & -4.0 \\
\hline 15661 & GI,Rr & chromosome segregation protein $(\mathrm{smc})$ & -5.8 & -4.0 \\
\hline 07771 & $\mathrm{M}, \mathrm{Cb}$ & $\begin{array}{l}\mathrm{N} \text {-acetylmannosamine-6-phosphate } \\
\text { 2-epimerase (nanEK) }\end{array}$ & -2.9 & -4.0 \\
\hline 15961 & $\mathrm{U}$ & possible protein phosphatase $2 \mathrm{C}$ & -7.5 & -3.6 \\
\hline 05030 & $\mathrm{M}$ & enolase & -3.8 & -3.6 \\
\hline 00705 & $\mathrm{U}, \mathrm{Om}$ & possible porin (som) & -1.7 & -3.6 \\
\hline
\end{tabular}


Table II.6 (continued 2 of 3 )

\begin{tabular}{|c|c|c|c|c|}
\hline $\begin{array}{l}\text { WH5701 } \\
\text { ID }\end{array}$ & $\begin{array}{l}1 \text { KEGG } \\
\text { Function }\end{array}$ & $\begin{array}{r}4.4 \mathrm{pM} \\
\text { rela }\end{array}$ & $\begin{array}{l}1 \mathrm{Cd}^{2+} \text { abundance } \\
\text { ative to control }\end{array}$ & $\begin{array}{l}44 \mathrm{pM} \mathrm{Cd}^{2+} \text { abundance } \\
\text { relative to control }\end{array}$ \\
\hline 15851 & PS & $\begin{array}{l}\text { ferredoxin-thioredoxin reductase } \\
\text { catalytic chain }\end{array}$ & -2.3 & -3.6 \\
\hline 02654 & Ukn & hypothetical protein & -4.6 & -3.4 \\
\hline 14481 & GI,T & 30S ribosomal protein $\mathrm{S} 16$ & -3.3 & -3.3 \\
\hline 05860 & Ukn & hypothetical protein & -3.6 & -3.2 \\
\hline 12094 & M,E,Op & putative inorganic pyrophosphatase & -4.3 & -2.9 \\
\hline 01210 & GI,T & $\begin{array}{l}\text { glutamyl-tRNA (Gln) amido-transferase } \\
\text { subunit C }\end{array}$ & -2.4 & -2.9 \\
\hline 05795 & PS & $\begin{array}{l}\text { photosystem I reaction center subunit II } \\
\quad(\mathrm{psaD})\end{array}$ & -4.9 & -2.8 \\
\hline 02864 & $\mathrm{M}, \mathrm{Cb}, \mathrm{L}$ & $\begin{array}{l}\text { acetyl-CoA carboxylase, biotin carboxyl } \\
\text { carrier protein }\end{array}$ & -3.5 & -2.8 \\
\hline 02634 & GI,T & 30 S ribosomal protein $\mathrm{S} 6$ & -3.1 & -2.8 \\
\hline 13185 & Ukn & hypothetical protein & -3.6 & -2.6 \\
\hline 12518 & M & $\begin{array}{l}\text { cytochrome c, class IC: cytochrome c, } \\
\text { class I }\end{array}$ & -1.7 & -2.6 \\
\hline 07651 & PS & $\begin{array}{l}\text { chloroplast membrane associated } \\
30 \mathrm{kD} \text { protein-like }\end{array}$ & -3.3 & -2.6 \\
\hline 02005 & $\mathrm{U}, \mathrm{M}, \mathrm{A}$ & $\begin{array}{l}\text { glycine cleavage system } \mathrm{H} \text { protein } \\
(\mathrm{gcvH})\end{array}$ & -2.4 & -2.5 \\
\hline 03459 & Ukn & hypothetical protein & -3.3 & -2.5 \\
\hline 03654 & M & $\begin{array}{l}\text { glycogen/starch/alpha-glucan } \\
\text { phosphorylase }\end{array}$ & -5.4 & -2.5 \\
\hline 14881 & $\mathrm{M}, \mathrm{G}$ & leucyl aminopeptidase & -2.3 & -2.4 \\
\hline 08229 & Ukn & hypothetical protein & -3.0 & -2.4 \\
\hline 01105 & Ukn & hypothetical protein & -3.4 & -2.4 \\
\hline 09725 & Ukn & hypothetical protein & -2.0 & -2.4 \\
\hline 15176 & Ukn & hypothetical protein & -2.5 & -2.3 \\
\hline 05360 & $\mathrm{GI}, \mathrm{F}$ & glutaredoxin & -1.8 & -2.3 \\
\hline 11984 & M,PS & possible ferredoxin $(2 \mathrm{Fe}-2 \mathrm{~S})$ & -2.3 & -2.3 \\
\hline 06581 & $\mathrm{U}, \mathrm{N}$ & NifU-like protein & -2.1 & -2.3 \\
\hline 15471 & M & ribose 5-phosphate isomerase & -2.3 & -2.2 \\
\hline 14806 & Ukn & hypothetical protein & -2.0 & -2.2 \\
\hline 01965 & $\mathrm{U}$ & rubrerythrin & -2.6 & -2.2 \\
\hline 13470 & Ukn & hypothetical protein & -1.8 & -2.2 \\
\hline 12873 & U,GI,F,G & thioredoxin peroxidase & -1.6 & -2.1 \\
\hline 06721 & Ukn & hypothetical protein & -2.0 & -2.1 \\
\hline 14866 & Ukn & hypothetical protein & -1.7 & -2.1 \\
\hline 02264 & Ukn & hypothetical protein & -2.5 & -2.0 \\
\hline 02929 & $\mathrm{U}, \mathrm{M}$ & $\begin{array}{l}\text { soluble hydrogenase small subunit } \\
\text { (DHSS) }\end{array}$ & -2.2 & -2.0 \\
\hline 11474 & Ukn & hypothetical protein & -1.2 & -2.0 \\
\hline 00840 & Ukn & hypothetical protein & -3.5 & -1.6 \\
\hline 02714 & $\mathrm{M}, \mathrm{A}, \mathrm{V}$ & threonine synthase & -3.0 & -1.8 \\
\hline
\end{tabular}


Table II.6 (continued 3 of 3 )

\begin{tabular}{|c|c|c|c|c|}
\hline $\begin{array}{l}\text { WH5701 } \\
\text { ID }\end{array}$ & $\begin{array}{l}1 \text { KEGG } \\
\text { Function }\end{array}$ & $\begin{array}{r}4.4 \mathrm{pM} \\
\text { relat }\end{array}$ & $\begin{array}{l}\mathrm{Cd}^{2+} \text { abundance } \\
\text { ive to control }\end{array}$ & $\begin{array}{l}44 \mathrm{pM} \mathrm{Cd}^{2+} \text { abundance } \\
\text { relative to control }\end{array}$ \\
\hline 08824 & U,GI,F & $\begin{array}{l}\text { putative bacterioferritin comigratory } \\
\text { (BCP) protein }\end{array}$ & -2.9 & -1.3 \\
\hline 10549 & Ukn & hypothetical protein & -2.8 & -1.4 \\
\hline 05450 & GI & $\begin{array}{l}\text { two component transcriptional } \\
\text { regulator, LuxR family protein }\end{array}$ & -2.4 & -1.3 \\
\hline 02030 & GI,T & 50S ribosomal protein L9 & -2.4 & -1.4 \\
\hline 14556 & $\mathrm{M}, \mathrm{Nu}, \mathrm{V}$ & $\begin{array}{l}\text { stationary-phase survival protein } \\
\text { (surE) }\end{array}$ & -2.4 & -2.0 \\
\hline 15506 & $\mathrm{GI}, \mathrm{T}$ & translation initiation factor IF-2 (infB) & -2.3 & -1.4 \\
\hline 14296 & Ukn & hypothetical protein & -2.2 & -1.3 \\
\hline 00735 & Ukn & hypothetical protein & -2.1 & -1.8 \\
\hline 03039 & M,A,Ly & dihydrodipicolinate synthase (dapA) & -2.1 & -2.0 \\
\hline 11499 & $\mathrm{M}, \mathrm{V}, \mathrm{Po}, \mathrm{chl}$ & ferritin (ftn) & -2.1 & -1.6 \\
\hline 16006 & Ukn,O & rehydrin & -2.1 & -1.7 \\
\hline 11924 & $\mathrm{GI}, \mathrm{T}$ & ribosome releasing factor & -2.0 & -1.0 \\
\hline 13085 & Ukn & hypothetical protein & -2.0 & -1.9 \\
\hline
\end{tabular}

Arranged in highest to lowest fold change, $44 \mathrm{pM} \mathrm{Cd}^{2+}$, then $4.4 \mathrm{pM} \mathrm{Cd}^{2+} .+=$ fold greater than control, $-=$ fold less than control, $\mathrm{C}=\mathrm{CO}_{2}$ fixation, $\mathrm{Ukn}=$ unknown, $\mathrm{PS}=$ photosynthesis, $\mathrm{U}=$ unclassified, $\mathrm{Om}=$ outer membrane protein, $\mathrm{M}=$ metabolism, $\mathrm{Nu}=$ nucleic acid metabolism, $\mathrm{St}=$ steroid hormone synthesis, $\mathrm{L}=$ lipid biosynthesis, $\mathrm{GI}=$ genetic information processing, $\mathrm{T}=$ translation, $\mathrm{BA}=$ branched chain amino asid metabolism, chl = chlorophyll biosynthesis, $\mathrm{E}=$ energy metabolism, $\mathrm{A}=$ amino acid metabolism, $\mathrm{Rr}=$ replication and repair, $\mathrm{Cb}=$ carbohydrate metabolism, $\mathrm{Op}=$ oxidative phosphorylation, $\mathrm{F}=$ protein folding, $\mathrm{N}=$ nitrogen metabolism, $\mathrm{G}=$ glutathione metabolism, $\mathrm{V}=$ vitamin metabolism, $\mathrm{Ly}=$ lysine synthesis, $\mathrm{Po}=$ porphyrin biosynthesis, $\mathrm{O}=$ oxidative stress. 


\section{Appendix III: Supplementary Data to Chapter 4}

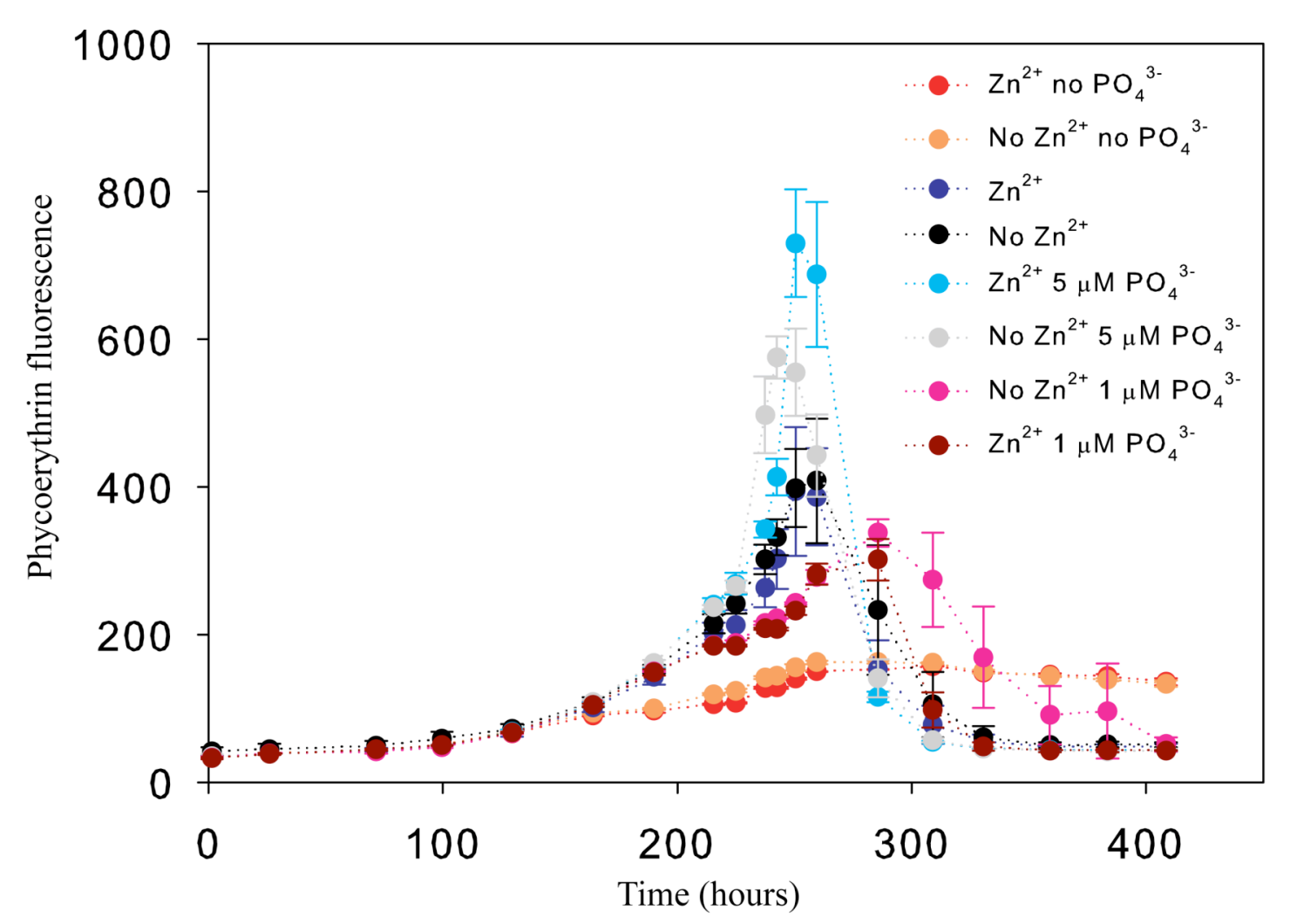

Figure III.1: Phycoerythrin fluorescence vs. time, chronic $\mathrm{PO}_{4}^{3-}$ limitation reconaissance study. Error bars are one standard deviation of triplicate $28 \mathrm{~mL}$ tubes. Note that no $\mathrm{PO}_{4}^{3-}$ added treatmnts, both with and without $\mathrm{Zn}^{2+}$ appear to have a stationary phase. $1 \mu \mathrm{M} \mathrm{PO}_{4}^{3-}$ treatments appear to have a brief stationary phase and then enter death phase, the $\mathrm{Zn}^{2+}$ dying faster than the no added $\mathrm{Zn}^{2+}$. The $5 \mu \mathrm{M} \mathrm{PO}_{4}^{3-}$ treatements fluoresced to a greater maximum than the $65 \mu \mathrm{M} \mathrm{PO}_{4}^{3-}$. This phenomenen is thus far unexplained and was not observed in a concurrent $500 \mathrm{~mL}$ experiment (four treatments, 1 and $65 \mu \mathrm{M} \mathrm{PO}_{4}{ }^{3-}$ with and without $\mathrm{Zn}^{2+}$ ). 


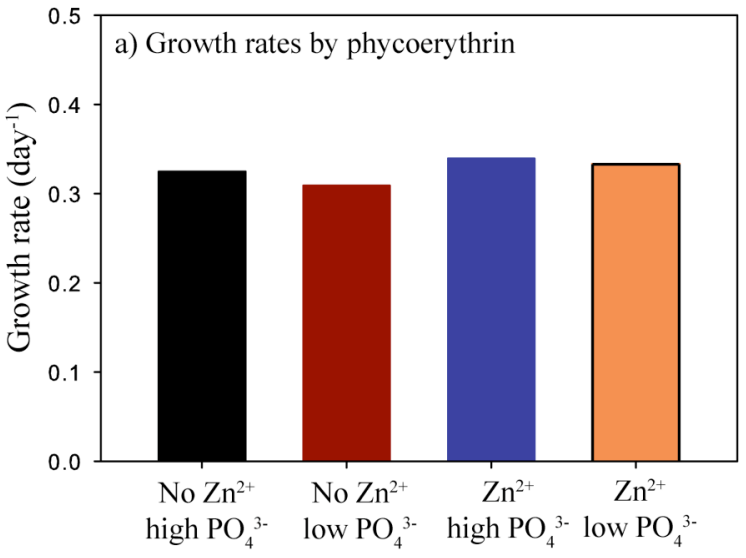

Treatment

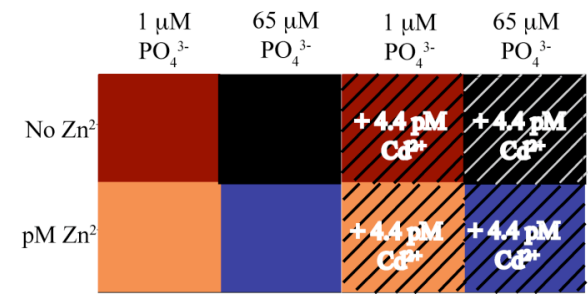

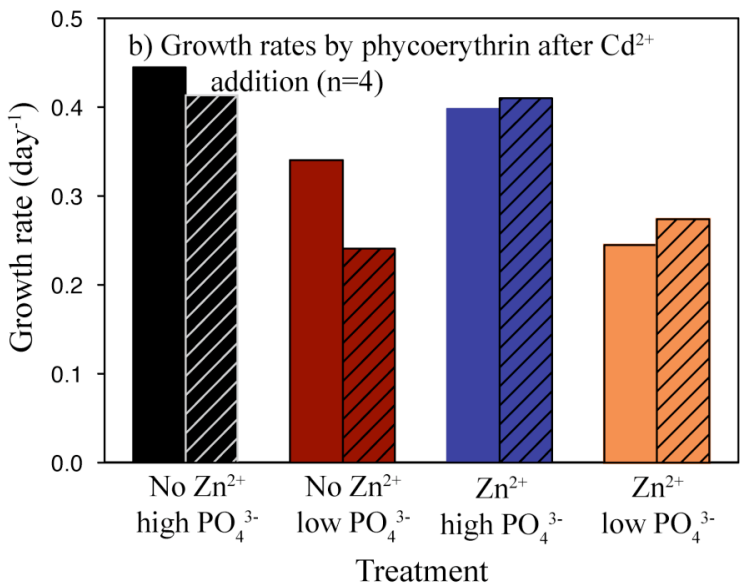

Figure III.2: a) Growth rates calculated by phycoerythrin. b) Growth rates calculated by phycoerythrin in the 24 hours after cadmium addition until harvest. Note that it yields similar values to actual growth rates throughout the experiment, but it shows decreased approximated growth rates relative to acutal growth rates in the $1 \mu \mathrm{M} \mathrm{PO}_{4}^{3-}$ treatments for the last 24 hours of the experiment. 
Table III.1: WH8102 proteins that are $\geq$ two-fold differentially abundant in the $\mathrm{Zn}^{2+} 1 \mu \mathrm{MPO}_{4}^{3-}+4.4$ pM Cd ${ }^{2+}$ vs. $\mathrm{Zn}^{2+} 65 \mu \mathrm{M} \mathrm{PO}_{4}^{3-}+4.4 \mathrm{pM} \mathrm{Cd}^{2+}$.

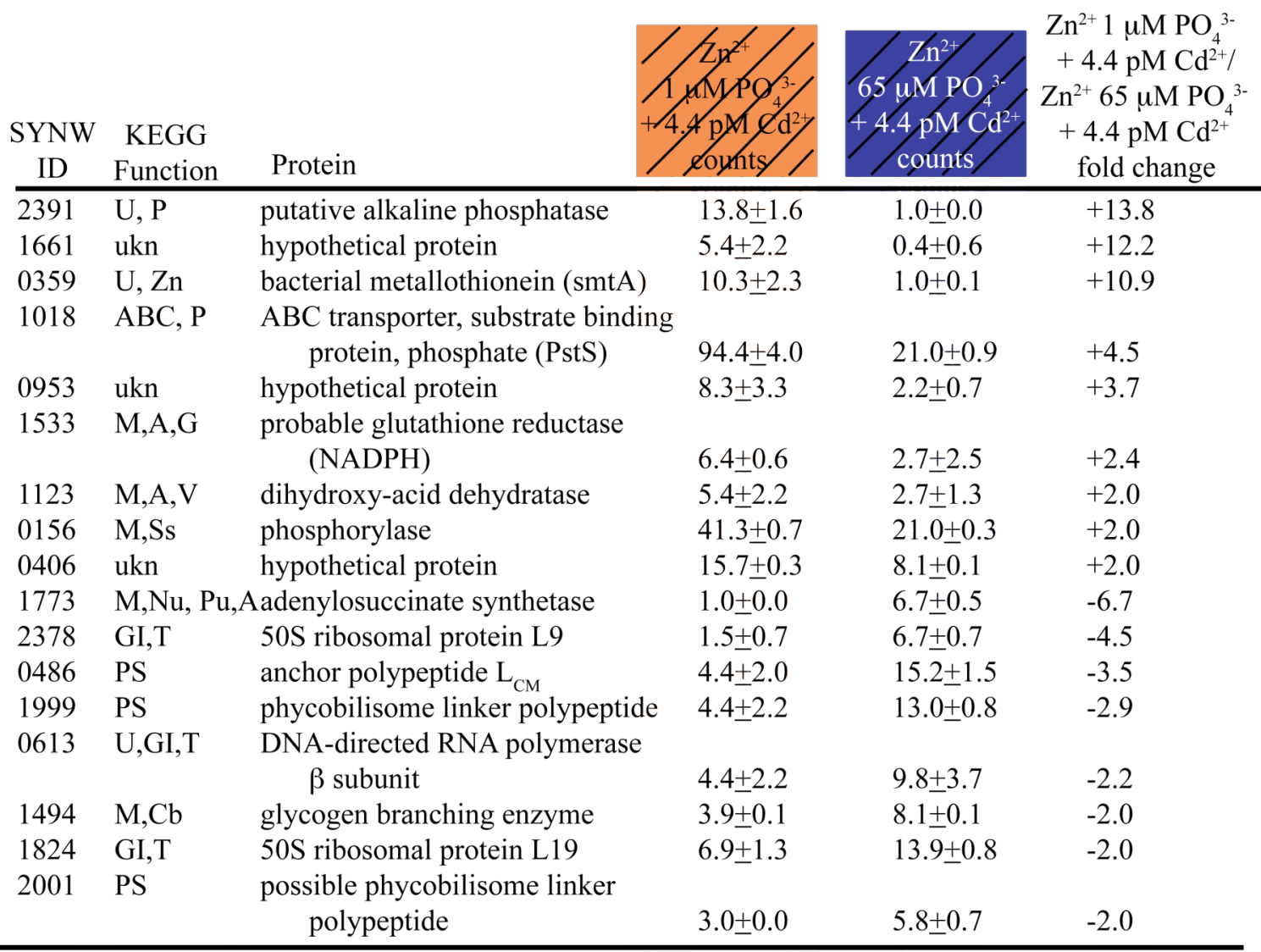

Arranged in highest to lowest fold change $\mathrm{Zn}$-low $\mathrm{PO}_{4}{ }^{3-} \mathrm{Cd}$ then $\mathrm{Zn}$-high $\mathrm{PO}_{4}{ }^{3-} \mathrm{Cd},+=$ fold greater than $\mathrm{Zn}-\mathrm{high}$ $\mathrm{PO}_{4}{ }^{3-} \mathrm{Cd}$, - = fold less thanZn-high $\mathrm{PO}_{4}{ }^{3-} \mathrm{Cd}, \mathrm{U}=$ unclassified, $\mathrm{P}=$ phosphorus metabolism, ukn $=$ unknown, $\mathrm{Zn}=$ zinc metabolism, $\mathrm{ABC}=\mathrm{ABC}$ transporter, $\mathrm{M}=$ metabolism, $\mathrm{A}=$ amino acid metabolism, $\mathrm{G}=$ glutathione metabolism, $\mathrm{V}=$ vitamin metabolism, $\mathrm{Ss}=$ sugar and starch metabolism, $\mathrm{Nu}=$ nucleic acid metabolism, $\mathrm{Pu}=$ purine metabolism, $\mathrm{A}=$ amino acid metabolsim, $\mathrm{GI}=$ genetic information processing, $\mathrm{T}=$ translation, $\mathrm{Cb}=$ carbohydrate metabolism. 
Table III.2: WH8102 proteins that are $\geq$ two-fold differentially abundant in the no $\mathrm{Zn}^{2+} 1 \mu \mathrm{M} \mathrm{PO}_{4}^{3-}+$ $4.4 \mathrm{pM} \mathrm{Cd}^{2+}$ vs. no $\mathrm{Zn}^{2+} 65 \mu \mathrm{M} \mathrm{PO}_{4}^{3-}+4.4 \mathrm{pM} \mathrm{Cd}^{2+}$.

No $\mathrm{Zn}^{2+}$

$1 \mu \mathrm{MPO}_{4}^{3-}$

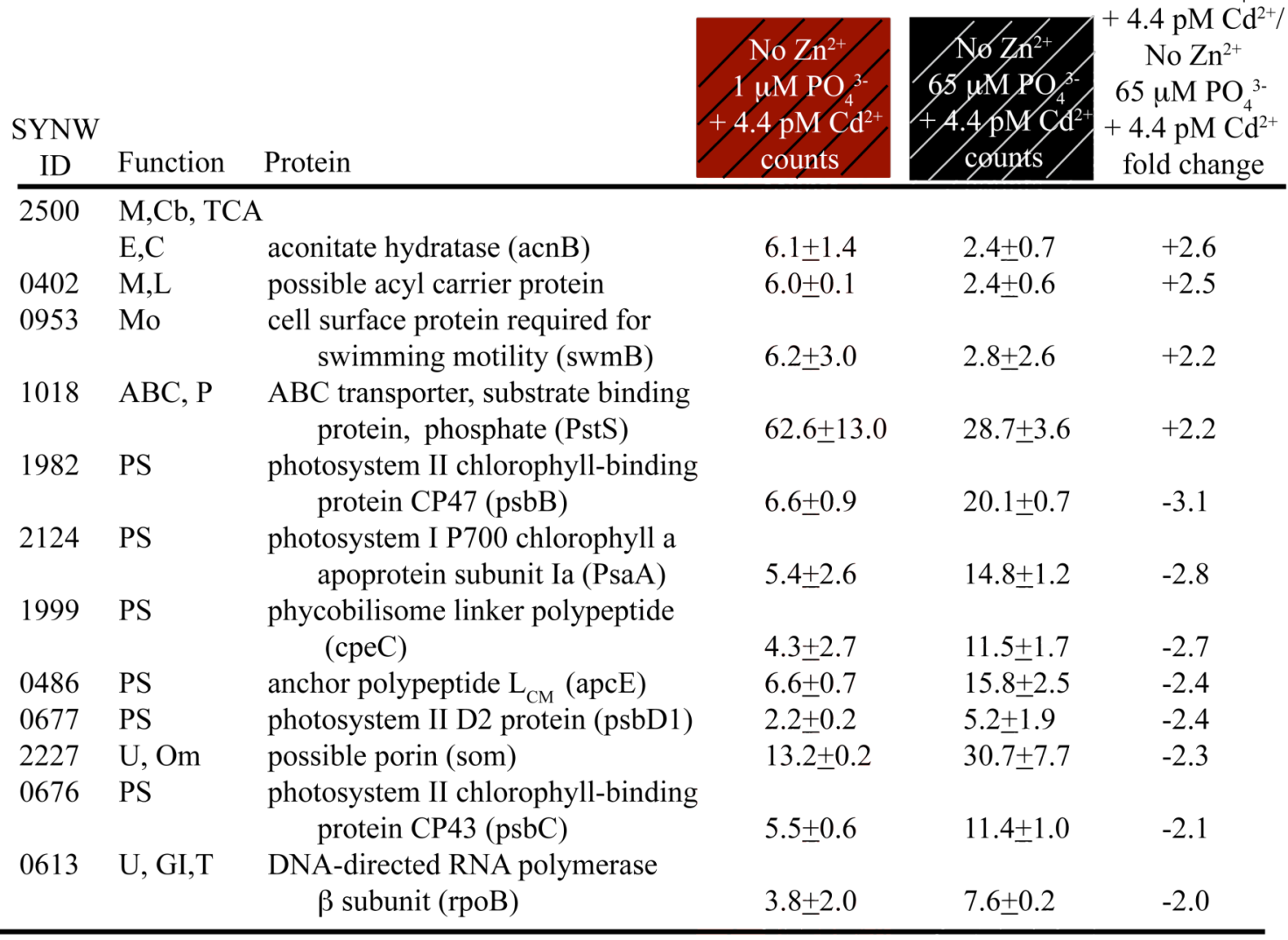

Arranged in highest to lowest fold change no $\mathrm{Zn}$-low $\mathrm{PO}_{4}{ }^{3-} \mathrm{Cd}$ then no $\mathrm{Zn}$-high $\mathrm{PO}_{4}{ }^{3-} \mathrm{Cd},+=$ fold greater than no $\mathrm{Zn}$-high $\mathrm{PO}_{4}^{3-} \mathrm{Cd}$, - = fold less than no $\mathrm{Zn}$-high $\mathrm{PO}_{4}^{3-} \mathrm{Cd}$. $\mathrm{M}=$ metabolism, $\mathrm{Cb}=$ carbohydrate metabolism, $\mathrm{TCA}=$ citrate cycle, $\mathrm{L}=$ lipid metabolism, $\mathrm{Mo}=$ motility, $\mathrm{ABC}=\mathrm{ABC}$ transporter, $\mathrm{P}=$ phosphorus metabolism, $\mathrm{PS}=$ photosynthesis, $\mathrm{U}=$ unclassified, $\mathrm{Om}=$ outer membrane protein, $\mathrm{GI}=$ genetic information processing, $\mathrm{T}=$ translation.

Table III.3: WH8102 proteins that are two-fold or more differentially abundant in the $\mathrm{Zn}^{2+} 65 \mu \mathrm{MPO}_{4}^{3-}+4.4$ pM Cd ${ }^{2+}$ vs. $\mathrm{Zn}^{2+} 65 \mu \mathrm{M} \mathrm{PO}_{4}^{3-}$.

$\mathrm{Zn}^{2+}$

\begin{tabular}{|c|c|c|c|c|c|}
\hline $\begin{array}{l}\text { SYNW } \\
\text { ID }\end{array}$ & Function & on Protein & & $\begin{array}{c}\mathrm{Zn}^{2+} \\
\begin{array}{c}65 \mathrm{M} \mathrm{PO}_{4}^{3-} \\
\text { counts }\end{array} \\
\end{array}$ & $\begin{array}{c}65 \mu \mathrm{M} \mathrm{PO}_{4}^{3-} \\
+4.4 \mathrm{pM} \mathrm{Cd}^{2+} / \\
\mathrm{Zn}^{2+} \\
65 \mu \mathrm{M} \mathrm{PO}_{4}^{3-} \\
\text { fold change }\end{array}$ \\
\hline 0486 & PS & anchor polypeptide $\mathrm{L}_{\mathrm{CM}}$ (apcE) & $15.2 \pm 1.5$ & $6.6 \pm 1.4$ & +2.3 \\
\hline 1982 & PS & $\begin{array}{l}\text { photosystem II chlorophyll-binding } \\
\text { protein CP47 (psbB) }\end{array}$ & $11.7 \pm 2.7$ & $5.1 \pm 3.2$ & +2.3 \\
\hline 2227 & $\mathrm{U}, \mathrm{Om} \mathrm{p}$ & possible porin (som) & $27.7 \pm 2.1$ & $13 . \overline{1}+1.6$ & +2.1 \\
\hline 1835 & PS $\quad p$ & $\begin{array}{l}\text { photosystem I reaction center subunit } \\
\text { III (psaF) }\end{array}$ & $5.8 \pm 0.6$ & $2.8 \pm 1.4$ & +2.1 \\
\hline
\end{tabular}

Arranged in highest to lowest fold change $\mathrm{Zn} 4.4 \mathrm{pM} \mathrm{Cd}^{2+} .+=$ fold greater than $\mathrm{Zn},-=$ fold less than $\mathrm{Zn}$. PS = photosynthesis, $\mathrm{U}=$ unclassified, $\mathrm{Om}=$ outer membrane protein. 
Table III.4: WH8102 proteins that are $\geq$ two-fold differentially abundant in the no $\mathrm{Zn}^{2+} 1 \mu \mathrm{MPO}_{4}^{3-}+4.4$ pM Cd${ }^{2+}$ vs. the no $\mathrm{Zn}^{2+} 1 \mu \mathrm{M} \mathrm{PO}_{4}^{3-}$.

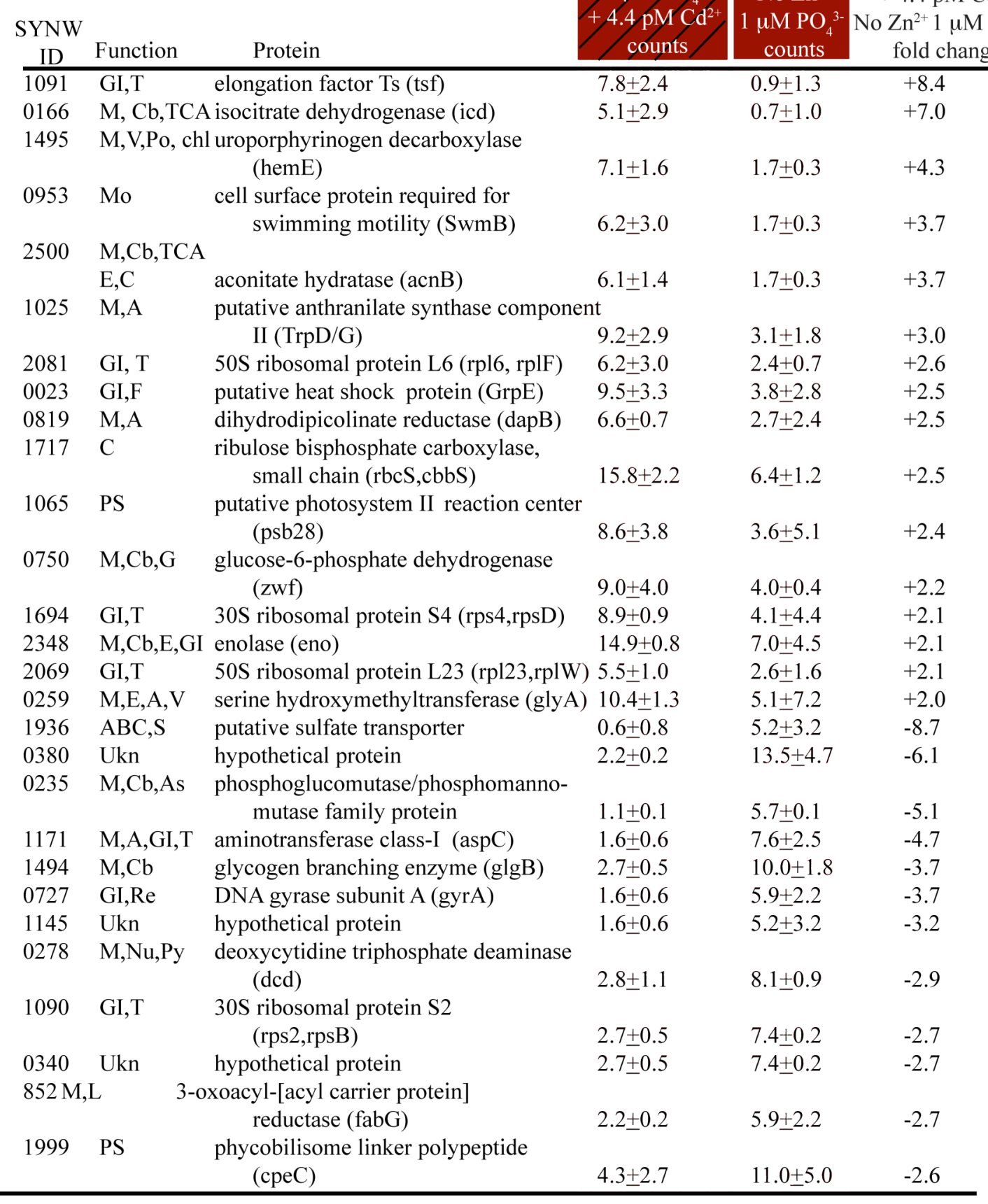


Table III.4 (continued, page 2 of 2):

\begin{tabular}{|c|c|c|c|c|c|}
\hline $\begin{array}{l}\text { SYNW } \\
\text { ID }\end{array}$ & Function & Protein & $\begin{array}{l}4 \mathrm{pM} \mathrm{Cd}^{2} \\
\text { counts }\end{array}$ & $\begin{array}{c}1 \mu \mathrm{M} \mathrm{PO}_{4}^{3-} \mathrm{I} \\
\text { counts }\end{array}$ & $\begin{array}{l}\text { No } \mathrm{Zn}^{2+} 1 \mu \mathrm{M} \mathrm{PO}_{4}{ }^{3-} \\
\text { fold change }\end{array}$ \\
\hline 1610 & $\mathrm{Rg}$ & \multicolumn{4}{|l|}{$\begin{array}{l}\text { putative bifuntional enzyme: tRNA } \\
\text { methyltransferase; } 2 \text {-C-methyl-D- } \\
\text { erythritol 2,4-cyclodiphosphate }\end{array}$} \\
\hline \multirow[t]{2}{*}{2124} & PS & $\begin{array}{l}\text { synthase } \\
\text { photosystem I P700 chlorophyll } a\end{array}$ & $2.2 \pm 0.2$ & $5.0 \pm 0.9$ & -2.3 \\
\hline & & apoprotein subunit Ia (psaA) & $5.4 \pm 2.6$ & $11.9 \pm 3.7$ & -2.2 \\
\hline 2040 & $\mathrm{M}, \mathrm{V}, \mathrm{Po}, \mathrm{ch}$ & coproporphyrinogen III oxidase (hemF) & $2.7 \pm 0.5$ & $5.9 \pm 2.2$ & -2.2 \\
\hline 2342 & GI,T & 50S ribosomal protein L1 (rpl1,rplA) & $4.3 \pm 1.1$ & $9.0 \pm 0.5$ & -2.1 \\
\hline
\end{tabular}

Arranged in highest to lowest fold change no $\mathrm{Zn}-$ low $\mathrm{PO}_{4}^{3-}+4.4 \mathrm{pM} \mathrm{Cd}^{2+}$ than no $\mathrm{Zn}-\mathrm{low} \mathrm{PO}_{4}^{3-}++=$ fold greater than no $\mathrm{Zn}$-low $\mathrm{PO}_{4}^{3-}$, - = fold less than no $\mathrm{Zn}$-low $\mathrm{PO}_{4}^{3-}, \mathrm{GI}=$ genetic information processing, $\mathrm{T}=$ translation, $\mathrm{M}=$ metabolism, $\mathrm{Cb}=$ carbohydrate metabolism, TCA $=$ citric acid cycle, $\mathrm{V}=$ vitamin metabolism, $\mathrm{Po}=$ porphryin metabolism, $\mathrm{chl}=$ chlorophyll metabolism, $\mathrm{Mo}=$ motility, $\mathrm{E}=$ enegy metabolism, $\mathrm{C}=$ carbon fixation, $\mathrm{A}=$ amino acid metabolism, $\mathrm{F}=$ folding, $\mathrm{G}=$ glutathione metabolism, $\mathrm{ABC}=\mathrm{ABC}$ transporter, $\mathrm{S}=$ sulfur metabolism, $\mathrm{Ukn}=$ unknown, $\mathrm{As}=$ amino sugar metabolism, $\mathrm{Re}=\mathrm{DNA}$ replication and repair, $\mathrm{Nu}=$ nucleic acid metabolism, $\mathrm{Py}=$ pyramidine metabolism, $\mathrm{L}=$ lipid metabolism, $\mathrm{PS}=$ photosynthesis, $\mathrm{Rg}=$ regulation .

Table III.5: WH8102 proteins that are $\geq$ two-fold differentially abundant in the $\mathrm{Zn}^{2+} 1 \mu \mathrm{M} \mathrm{PO}_{4}{ }^{3-}+4.4$ pM Cd ${ }^{2+}$ vs. $\mathrm{Zn}^{2+} 1 \mu \mathrm{MPO}_{4}^{3-}$.

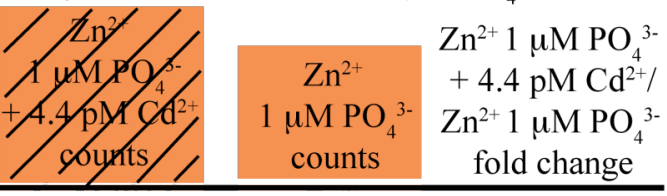

\begin{tabular}{|c|c|c|c|c|c|}
\hline $\begin{array}{l}\text { SYNW } \\
\text { ID }\end{array}$ & Function & Protein & & $\begin{array}{l}1 \mu \mathrm{MPO}_{4}^{3-} \\
\text { counts }\end{array}$ & $\begin{array}{l}\mathrm{Zn}^{2+} 1 \mu \mathrm{MPO}_{4}^{3-} \\
\text { fold change }\end{array}$ \\
\hline 1933 & $\mathrm{M}, \mathrm{V}, \mathrm{Po}, \mathrm{chl}$ & $\begin{array}{c}\delta \text {-aminolevulinic acid } \\
\text { dehydratase }\end{array}$ & $5.9 \pm 1.3$ & $1.9 \pm 1.4$ & +3.1 \\
\hline 1716 & $\mathrm{C}$ & $\begin{array}{l}\text { putative carboxysome structural } \\
\text { peptide (CsoS2) }\end{array}$ & $15.2 \pm 1.8$ & $6.6 \pm 0.1$ & +2.3 \\
\hline 0304 & $\mathrm{M}, \mathrm{S}, \mathrm{Pu}, \mathrm{Se}$ & ATP-sulfurylase & $2.5 \pm 0.7$ & $9.0 \pm 0.8$ & -3.7 \\
\hline 0160 & Ukn & hypothetical protein & $3.0 \pm 0.0$ & $7.6 \pm 1.2$ & -2.6 \\
\hline 1953 & Ukn, L & putative glycerol kinase & $2.5 \pm 0.7$ & $5.7 \pm 0.1$ & -2.3 \\
\hline 1494 & $\mathrm{M}, \mathrm{Cb}$ & glycogen branching enzyme & $3.9 \pm 0.1$ & $9.0 \pm 1.9$ & -2.3 \\
\hline 1650 & $(\mathrm{M}, \mathrm{A})$ & ketol-acid reducto-isomerase & $7.9 \pm 1.3$ & $15.7 \pm 0.4$ & -2.0 \\
\hline
\end{tabular}

Arranged in highest to lowest fold change $\mathrm{Zn}-$ low $\mathrm{PO}_{4}^{3-}+4.4 \mathrm{pM} \mathrm{Cd}^{2+}$ than $\mathrm{Zn}-1$ low $\mathrm{PO}_{4}^{3-} .+=$ fold greater than $\mathrm{Zn}$-low $\mathrm{PO}_{4}^{3-},-=$ fold less than $\mathrm{Zn}$-low $\mathrm{PO}_{4}^{3-}, \mathrm{M}=$ metabolism, $\mathrm{V}=$ vitamin metabolism, $\mathrm{Po}=$ porphyrin metabolism, $\mathrm{chl}=$ chlorophyll metabolism, $\mathrm{C}=$ carbon fixation, $\mathrm{S}=$ sulfur metabolism, $\mathrm{Pu}=$ purine metabolism, $\mathrm{Se}=$ selenoaminoacid metabolism, $\mathrm{Ukn}=$ unknown, $\mathrm{L}=$ lipid metabolism, $\mathrm{Cb}=$ carbohydrate metabolism, $\mathrm{A}=$ amino acid metabolism . 
Table III.6: WH8102 proteins that are $\geq$ two-fold differentially abundant in the $\mathbf{n o} \mathbf{Z n}^{2+} \mathbf{6 5} \boldsymbol{\mu} \mathbf{M} \mathbf{P O} \mathbf{4}^{3-}$ vs.

\begin{tabular}{|c|c|c|c|c|c|}
\hline $\begin{array}{c}\mathrm{Zn}^{2+} 6 \\
\text { SYNV } \\
\text { ID }\end{array}$ & $\begin{array}{l}\mu \mathrm{MPO}_{4}{ }^{3-} . \\
\text { Function }\end{array}$ & Protein & $\begin{array}{l}\text { No } \mathrm{Zn}^{2+} \\
65 \mu \mathrm{MOO}_{4}^{3-} \\
\text { counts }\end{array}$ & $\begin{array}{l}\mathrm{Zn}^{2+} \\
65 \mu \mathrm{M} \mathrm{PO}_{4}^{3-} \\
\text { counts }\end{array}$ & $\begin{array}{c}\text { No } \mathbf{Z n}^{2+} 65 \mu \mathrm{M} \mathrm{PO}_{4}{ }^{3-} \\
\mathrm{Zn}^{2+} 65 \mu \mathrm{MPO}_{4}{ }^{3-} \\
\text { fold change }\end{array}$ \\
\hline$\overline{2139}$ & GI,T & 30S ribosomal protein S10 & $5.5 \pm 1.7$ & $1.9 \pm 0.0$ & +3.0 \\
\hline 0303 & PS & $\begin{array}{l}\text { photosystem II manganese- } \\
\text { stabilizing polypeptide (psbO) }\end{array}$ & $35.7 \pm 7.5$ & $13.6 \pm 2.2$ & +2.6 \\
\hline 1982 & PS & $\begin{array}{l}\text { photosystem II chlorophyll-binding } \\
\text { protein CP47(psbB) }\end{array}$ & $13.2+2.1$ & $5.1 \pm 3.2$ & +2.6 \\
\hline 0032 & GI,T,F & $\begin{array}{l}\text { putative cyclophilin-type peptidyl- } \\
\text { prolyl cis-trans isomerase }\end{array}$ & $6.0+0.1$ & $2.3+0.6$ & +2.6 \\
\hline 0045 & U,M & $\begin{array}{l}\text { soluble hydrogenase small subunit } \\
\text { (DHSS) }\end{array}$ & $7.2 \pm 2.8$ & $2.8 \pm 1.4$ & +2.6 \\
\hline 0085 & Mo & $\begin{array}{l}\text { cell surface protein required for } \\
\text { swimming motility (swmA) }\end{array}$ & $10.7 \pm 0.9$ & $4.2 \pm 0.6$ & +2.5 \\
\hline 1835 & PS & $\begin{array}{l}\text { photosystem I reaction center } \\
\text { subunit III (psaF) }\end{array}$ & $6.9 \pm 2.6$ & $2.8 \pm 1.4$ & +2.4 \\
\hline 1118 & $\begin{array}{l}\mathrm{M}, \mathrm{Cb}, \mathrm{St} \\
\mathrm{Su}, \mathrm{As}\end{array}$ & $\begin{array}{l}\text { glucose-1-phosphate } \\
\text { adenylyltransferase }\end{array}$ & $5.5 \pm 0.5$ & $2.3 \pm 3.3$ & +2.4 \\
\hline 1933 & $\mathrm{M}, \mathrm{V}, \mathrm{Po}, \mathrm{chl}$ & $\delta$-aminolevulinic acid dehydratase & $7.2 \pm 1.6$ & $3.3 \pm 0.6$ & +2.2 \\
\hline 0546 & GI,T & 50 S ribosomal protein L27 & $5.1 \pm 1.1$ & $2.3 \pm 0.6$ & +2.2 \\
\hline 1518 & ukn & hypothetical protein & $19.2 \pm 0.1$ & $8.9 \pm 0.5$ & +2.2 \\
\hline 0827 & ukn & hypothetical protein & $3.4 \pm 0.1$ & $11.2 \pm 2.4$ & -3.3 \\
\hline 0278 & $\mathrm{M}, \mathrm{Nu}, \mathrm{Py}$ & $\begin{array}{l}\text { deoxycytidine triphosphate } \\
\text { deaminase }\end{array}$ & $2.1 \pm 0.7$ & $6.5 \pm 1.2$ & -3.1 \\
\hline 2191 & PS & $\begin{array}{l}\text { photosystem II complex extrinsic } \\
\text { protein precursor (psuB) }\end{array}$ & $5.5 \pm 1.7$ & $16.4 \pm 1.0$ & -3.0 \\
\hline 0670 & ukn & hypothetical protein & $2.2 \pm 1.9$ & $5.6 \pm 1.4$ & -2.6 \\
\hline 2310 & GI,F & glutaredoxin & $4.3 \pm 0.1$ & $8.4 \pm 1.2$ & -2.0 \\
\hline
\end{tabular}

Arranged in highest to lowest fold change no $\mathrm{Zn}$ than $\mathrm{Zn} .+=$ fold greater than $\mathrm{Zn},-=$ fold less than $\mathrm{Zn}, \mathrm{GI}=$ genetic information processing, $\mathrm{T}=$ translation, $\mathrm{PS}=$ photosynthesis, $\mathrm{F}=$ folding, $\mathrm{U}=$ unclassified, $\mathrm{M}=$ metabolism, $\mathrm{Mo}=$ motility, $\mathrm{Cb}=$ carbohydrate metabolism, $\mathrm{St}=$ starch metabolism, $\mathrm{Su}=$ sugar metabolism, As = amino and nucleotide sugar metabolism, $\mathrm{V}=$ vitamin metabolism, $\mathrm{Po}=$ porphyrin metabolism, $\mathrm{chl}=$ chlorophyll metabolism, $\mathrm{ukn}=$ unknown, $\mathrm{Nu}=$ nucleotide metabolism, $\mathrm{Py}=$ pyrimidine metabolism 
Table III.7: WH8102 proteins that are $\geq$ two-fold differentially abundant in the no $\mathrm{Zn}^{2+} 1 \mu \mathrm{MPO}_{4}^{3-}$ vs. the $\mathrm{Zn}^{2+} 1 \mu \mathrm{M} \mathrm{PO}_{4}^{3-}$.

\begin{tabular}{|c|c|c|c|c|c|}
\hline $\begin{array}{l}\text { SYNI } \\
\text { ID }\end{array}$ & Function & Protein & $\begin{array}{l}1 \mu \mathrm{MO}_{4}{ }^{3} \\
\text { counts }\end{array}$ & $\begin{array}{l}1 \mu \mathrm{MPO}_{4}^{3-} \\
\text { counts }\end{array}$ & $\begin{array}{l}\mathrm{Zn}^{2+} 1 \mu \mathrm{M} \mathrm{PO}_{4}^{3-} \\
\text { fold change }\end{array}$ \\
\hline$\overline{1090}$ & $\overline{\mathrm{GI}, \mathrm{T}}$ & $30 \mathrm{~S}$ ribosomal protein $\mathrm{S} 2$ & $7.4 \pm 0.2$ & $0.5 \pm 0.7$ & +15.7 \\
\hline 0235 & $\mathrm{M}, \mathrm{Cb}, \mathrm{As}$ & $\begin{array}{l}\text { phosphoglucomutase/phospho- } \\
\text { mannomutase family protein }\end{array}$ & $5.7 \pm 0.1$ & $0.5 \pm 0.7$ & +12.1 \\
\hline 0380 & Ukn & hypothetical protein & $13.5 \pm 4.7$ & $1.9 \pm 0.0$ & +7.1 \\
\hline 0727 & GI,Re & DNA gyrase subunit A (gyrA) & $5.9 \pm 2.2$ & $1.0 \pm 0.0$ & +6.2 \\
\hline 1145 & Ukn & hypothetical protein & $5.2 \pm 3.2$ & $1.0 \pm 0.0$ & +5.4 \\
\hline 0340 & Ukn & hypothetical protein & $7.4 \pm 0.2$ & $1.9 \pm 1.4$ & +3.9 \\
\hline 1610 & $\mathrm{Rg}$ & $\begin{array}{l}\text { putative bifuntional enzyme: } \\
\text { tRNA methyltransferase; 2-C- } \\
\text { methyl-D-erythritol 2,4-cyclo- } \\
\text { diphosphate synthase }\end{array}$ & $5.0 \pm 0.9$ & $1.4 \pm 0.7$ & +3.5 \\
\hline 1852 & M,L & $\begin{array}{l}\text { 3-oxoacyl-[acyl carrier protein] } \\
\text { reductase (fabG) }\end{array}$ & $5.9 \pm 2.2$ & $1.9 \pm 0.0$ & +3.1 \\
\hline 1171 & M,A,GI,T & aminotransferase class-I (aspC) & $7.6 \pm 2.5$ & $3.3 \pm 0.6$ & +2.3 \\
\hline 2001 & PS & $\begin{array}{l}\text { possible phycobilisome linker } \\
\text { polypeptide (cpeE) }\end{array}$ & $7.4 \pm 0.2$ & $3.3 \pm 0.7$ & +2.2 \\
\hline 2342 & GI,T & $\begin{array}{l}50 \mathrm{~S} \text { ribosomal protein } \mathrm{L} 1 \\
\quad(\mathrm{rp} 11, \mathrm{rplA})\end{array}$ & $9.0 \pm 0.5$ & $4.3 \pm 0.7$ & +2.1 \\
\hline 0359 & $\mathrm{U}, \mathrm{Zn}$ & bacterial metallothionein (smtA) & $1.2 \pm 0.3$ & $7.1 \pm 3.2$ & -5.8 \\
\hline 1495 & $\mathrm{M}, \mathrm{V}, \mathrm{Po}, \mathrm{chl}$ & $\begin{array}{l}\text { uroporphyrinogen decarboxylase } \\
\text { (hemE) }\end{array}$ & $1.7 \pm 0.3$ & $7.6 \pm 1.2$ & -4.6 \\
\hline 0953 & Mo & $\begin{array}{l}\text { cellsurface protein required for } \\
\text { swimming motility (SwmB) }\end{array}$ & $1.7 \pm 0.3$ & $5.2 \pm 0.6$ & -3.1 \\
\hline 2356 & GI,T & $\begin{array}{l}\text { aspartyl/glutamyl-tRNA amido- } \\
\text { transferase subunit B (gatB) }\end{array}$ & $2.4 \pm 0.7$ & $7.1 \pm 0.6$ & -3.0 \\
\hline 1025 & M,A & $\begin{array}{l}\text { putative anthranilate synthase } \\
\text { component II (trpD/G) }\end{array}$ & $3.1 \pm 1.8$ & $8.5 \pm 0.1$ & -2.7 \\
\hline 0750 & $\mathrm{M}, \mathrm{Cb}, \mathrm{G}$ & $\begin{array}{l}\text { glucose-6-phosphate } \\
\text { dehydrogenase (zwf) }\end{array}$ & $4.0 \pm 0.4$ & $10.4 \pm 1.2$ & -2.6 \\
\hline 2348 & $\mathrm{M}, \mathrm{Cb}, \mathrm{E}, \mathrm{GI}$ & enolase (eno) & $7.0 \pm 4.5$ & $17.5 \pm 1.7$ & -2.5 \\
\hline 1065 & PS & $\begin{array}{l}\text { putative photosystem II reaction } \\
\text { center (Psb28) }\end{array}$ & $3.6 \pm 5.1$ & $9.0 \pm 0.5$ & -2.5 \\
\hline 2391 & U,P & putative alkaline phosphatase & $3.3 \pm 0.6$ & $8.1 \pm 0.8$ & -2.4 \\
\hline 0128 & Ukn & hypothetical protein & $2.4 \pm 0.7$ & $5.7 \pm 0.1$ & -2.4 \\
\hline 0033 & GI,T & elongation factor $\mathrm{P}(\mathrm{efp})$ & $2.4 \pm 0.7$ & $5.7 \pm 1.2$ & -2.4 \\
\hline 0819 & M,A & $\begin{array}{l}\text { dihydrodipicolinate reductase } \\
\text { (dapB) }\end{array}$ & $2.7 \pm 2.4$ & $6.2 \pm 0.6$ & -2.3 \\
\hline 1119 & $\mathrm{M}, \mathrm{Cb}, \mathrm{G}$ & $\begin{array}{l}\text { 6-phosphogluconate dehydrogenase } \\
\text { (gnd) }\end{array}$ & $2.9 \pm 4.1$ & $6.6 \pm 0.1$ & -2.3 \\
\hline 0160 & Ukn & hypothetical protein & $3.3 \pm 0.6$ & $7.6 \pm 1.2$ & -2.3 \\
\hline 1661 & Ukn & hypothetical protein & $2.4 \pm 0.7$ & $5.2 \pm 2.1$ & -2.2 \\
\hline 0023 & $\mathrm{GI}, \mathrm{F}$ & putative heat shock protein (GrpE) & $3.8 \pm 2.8$ & $8.1 \pm 0.5$ & -2.1 \\
\hline
\end{tabular}


Table III.7 (continued, page 2 of 2):

SYNW

ID Function Protein
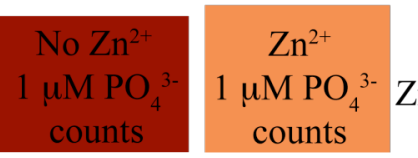

No $\mathrm{Zn}^{2+}$

$0082 \mathrm{M}, \mathrm{V}, \mathrm{R}$ riboflavin synthase subunit beta

$$
5.3+4.8
$$

$10.9+2.2$

$1 \mu \mathrm{MPO}_{4}^{3-1}$

$1 \mu \mathrm{M} \mathrm{PO}_{4}^{3-} \mathrm{Zn}^{2+} 1 \mu \mathrm{MPO}_{4}{ }^{3-}$ counts fold change

0613 U,GI,T

DNA-directed RNA polymerase beta subunit (rpoB)

$4.0 \pm 0.4$

$8.1 \pm 0.8$

$-2.1$

$1717 \mathrm{C}$

1533 M,G

ribulose bisphosphate carboxylase, small chain (rbcS,cbbS)

$6.4 \pm 1.2$

$12.8 \pm 1.8$

probable glutathione reductase

(NADPH) (gshR)

$3.1 \pm 1.8$

$6.2 \pm 0.8$

$-2.0$

$-2.0$

Arranged in highest to lowest fold change no $\mathrm{Zn}$-low $\mathrm{PO}_{4}^{3-}$ than $\mathrm{Zn}$-low $\mathrm{PO}_{4}^{3-} .+=$ fold greater than $\mathrm{Zn}-$ low $\mathrm{PO}_{4}^{3-},-$ - = fold less than $\mathrm{Zn}$-low $\mathrm{PO}_{4}^{3-}$. GI = genetic information processing, $\mathrm{T}=$ translation, $\mathrm{M}=$ metabolism, $\mathrm{Cb}=$ carbohydrate metabolism, As $=$ amino sugar metabolism, $\mathrm{Ukn}=$ unknown, $\mathrm{Re}=\mathrm{DNA}$ replication and repair, $\mathrm{Rg}=$ regulatory function, $\mathrm{L}=$ lipid metbolism, $\mathrm{A}=$ amino acid metabolism, $\mathrm{U}=$ unclassified, $\mathrm{Zn}=$ zinc metabolism, $\mathrm{V}=$ vitamin metabolism, $\mathrm{Po}=$ porphryin metabolism, $\mathrm{chl}=$ chlorophyll metabolism, $\mathrm{Mo}=$ motility, $\mathrm{G}=$ glutathione metabolism, $\mathrm{E}=$ energy metabolism, $\mathrm{PS}=$ photosynthesis, $\mathrm{P}=$ phosphorus metabolism, $\mathrm{R}=$ riboflavin metabolsim, $\mathrm{C}=$ carbon fixation.

Table III.8: WH8102 proteins that are $\geq$ two-fold differentially abundant in the no $\mathrm{Zn}^{2+} 65 \mu \mathrm{M} \mathrm{PO}{ }_{4}^{3-}+$ $4.4 \mathrm{pM} \mathrm{Cd}^{2+}$ vs. $\mathrm{Zn}^{2+} 65 \mu \mathrm{M} \mathrm{PO}_{4}^{3-}+4.4 \mathrm{pM} \mathrm{Cd}^{2+}$.

\begin{tabular}{|c|c|c|c|c|c|}
\hline $\begin{array}{l}\text { SYWN } \\
\text { ID }\end{array}$ & Function & Protein & $\begin{array}{l}6 \mathrm{Zn}^{2+} \\
\mathrm{M} \mathrm{PO}^{2-} \\
\text { pus } \mathrm{Ca}^{2+} \\
\text { ounts }\end{array}$ & $\begin{array}{l}\mathrm{Zn}^{2+} \\
65 \mathrm{uM} \mathrm{PO}^{3} \\
4.4 \mathrm{pM} \mathrm{Cd}^{2+} \\
\text { counts }\end{array}$ & $\begin{array}{c}\text { No } \mathrm{Zn}^{2+} 65 \mu \mathrm{M} \mathrm{PO}_{4} \\
+4.4 \mathrm{pM} \mathrm{Cd}^{2+} / \\
\mathrm{Zn}^{2+} 65 \mu \mathrm{M} \mathrm{PO}_{4}^{3-} \\
+4.4 \mathrm{pM} \mathrm{Cd}^{3+} \\
\text { fold change }\end{array}$ \\
\hline$\overline{0406}$ & Ukn & hypothetical protein & $19.6 \pm 1.3$ & $8.1 \pm 0.1$ & +2.4 \\
\hline 0405 & $\mathrm{M}, \mathrm{Nu}, \mathrm{Pu}, \mathrm{A}$ & $\begin{array}{l}\text { fumarate lyase:adenylo- } \\
\text { succinate lyase (purB) }\end{array}$ & $1.9 \pm 0.1$ & $6.3 \pm 1.4$ & -3.3 \\
\hline 2500 & $\mathrm{M}, \mathrm{Cb}, \mathrm{TCA}, \mathrm{E}$ & aconitate hydratase (acnB) & $2.4 \pm 0.7$ & $6.3 \pm 1.4$ & -2.6 \\
\hline
\end{tabular}

Arranged in highest to lowest fold change no $\mathrm{Zn}$-high $\mathrm{PO}_{4}{ }^{3-} \mathrm{Cd}$ han $\mathrm{Zn}$-high $\mathrm{PO}_{4}{ }^{3-} \mathrm{Cd}$. $+=$ fold greater than $\mathrm{Zn}$-high $\mathrm{PO}_{4}{ }^{3-} \mathrm{Cd}$, - = fold less than $\mathrm{Zn}$-high $\mathrm{PO}_{4}{ }^{3-} \mathrm{Cd}$, Ukn = unknown, $\mathrm{M}=$ metabolism, $\mathrm{Nu}=$ nucleotide metabolsim, $\mathrm{Pu}=$ purine metabolism, $\mathrm{A}=$ amino acid metabolism, $\mathrm{Cb}=$ carbohydrate metabolism, $\mathrm{TCA}=$ citrate cycle, $\mathrm{E}=$ energy metabolism, $\mathrm{C}=$ carbon fixation (in this case reductive carboxylate cycle). 
Table III.9: WH8102 proteins that are $\geq$ two-fold differentially abundant in the no $\mathrm{Zn}^{2+} 1 \mu \mathrm{M} \mathrm{PO}_{4}^{3-}+$ $4.4 \mathrm{pM} \mathrm{Cd}^{2+}$ vs. $\mathrm{Zn}^{2+} 1 \mu \mathrm{M} \mathrm{PO}_{4}{ }^{3-}+4.4 \mathrm{pM} \mathrm{Cd}^{2+}$.

\begin{tabular}{|c|c|c|c|c|c|}
\hline $\begin{array}{l}\text { SYNW } \\
\text { ID }\end{array}$ & Function & Protein & $\begin{array}{c}1 \mu \mathrm{MPO} \mathrm{PO}^{3-} \\
4.4 \mathrm{pM} \mathrm{Cd}^{2+} \\
\text { counts }\end{array}$ & & $\begin{array}{c}\mathrm{C} \mathrm{Zn}^{2+} 1 \mu \mathrm{M} \mathrm{PO}{ }_{4} \\
+4.4 \mathrm{pM} \mathrm{Cd}^{2+} \\
/ \mathrm{Zn}^{2+} 1 \mu \mathrm{M} \mathrm{PO}_{4}{ }^{3} \\
+4.4 \mathrm{pM} \mathrm{Cd}^{2+} \\
\text { fold change }\end{array}$ \\
\hline$\overline{0166}$ & $\mathrm{M}, \mathrm{Cb}, \mathrm{TCA}$ & isocitrate dehydrogenase & $5.1 \pm 2.9$ & $1.0 \pm 0.0$ & +5.2 \\
\hline 0304 & $\mathrm{M}, \mathrm{S}, \mathrm{Pu}, \mathrm{Se}$ & ATP-sulfurylase & $6.0 \pm 0.1$ & $2.5 \pm 0.7$ & +2.5 \\
\hline 1091 & GI & elongation factor Ts & $7.8 \pm 2.4$ & $3.5 \pm 0.7$ & +2.3 \\
\hline 1815 & $\mathrm{ABC}, \mathrm{P}$ & $\begin{array}{l}\mathrm{ABC} \text { transporter, substrate binding } \\
\text { protein, phosphate }\end{array}$ & $7.7 \pm 0.8$ & $3.9 \pm 1.4$ & +2.0 \\
\hline 1650 & $(\mathrm{M}, \mathrm{A})$ & ketol-acid reductoisomerase & $15 . \overline{3} \pm 1.5$ & $7.9 \pm 1.3$ & +2.0 \\
\hline 0359 & $\mathrm{U}, \mathrm{Zn}$ & bacterial metallothionein & $1.0 \pm 0.0$ & $10 . \overline{3} \pm 2.3$ & -10.2 \\
\hline 2391 & $\mathrm{U}, \mathrm{P}$ & putative alkaline phosphatase & $1.6 \pm 0.6$ & $13.8 \pm 1.6$ & -8.5 \\
\hline 1533 & $\mathrm{M}, \mathrm{A}, \mathrm{G}$ & $\begin{array}{l}\text { probable glutathione reductase } \\
\text { (NADPH) }\end{array}$ & $2.6 \pm 2.1$ & $6.4 \pm 0.6$ & -2.4 \\
\hline 0033 & GI, T & elongation factor $\mathrm{P}$ & $2.7 \pm 0.5$ & $5.4 \pm 0.8$ & -2.0 \\
\hline
\end{tabular}

Arranged in highest to lowest fold change no $\mathrm{Zn}-$ low $\mathrm{PO}_{4}{ }^{3-}+\mathrm{Cd}$ than $\mathrm{Zn}$-low $\mathrm{PO}_{4}{ }^{3-}+\mathrm{Cd} .+=$ fold greater than Zn-low $\mathrm{PO}_{4}^{3-}+\mathrm{Cd}$, - = fold less thanZn-low $\mathrm{PO}_{4}^{3-}+\mathrm{Cd}, \mathrm{M}=$ metabolism, $\mathrm{Cb}=$ carbohydrate metabolism, TCA $=$ citrate cycle, $\mathrm{S}=$ sulfur metabolism, $\mathrm{Pu}=$ purine metabolism, $\mathrm{Se}=$ selenoaminoacid metabolism, $\mathrm{GI}=$ genetic information processing, $\mathrm{ABC}=\mathrm{ABC}$ transporter, $\mathrm{P}=$ phosphorus metabolism, $\mathrm{A}=$ amino acid metabolism, $\mathrm{U}=$ unknown, $\mathrm{Zn}=$ zinc metabolism, $\mathrm{G}=$ glutathione metabolism, $\mathrm{T}=$ translation.

Table III.10: WH8102 proteins that are $\geq$ two-fold differentially abundant in the no $\mathrm{Zn}^{2+} 65 \mu \mathrm{M} \mathrm{PO}_{4}^{3-}$

\begin{tabular}{|c|c|c|c|c|c|}
\hline $\begin{array}{l}\text { SYNW } \\
\text { ID }\end{array}$ & $\mathrm{d}^{2+}$ vs. $Z \mathrm{n}^{2}$ & $\begin{array}{r}15 \\
68 y \\
+4.4\end{array}$ & 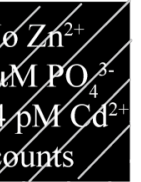 & $\begin{array}{c}\mathrm{Zn}^{2+} \\
\begin{array}{c}\mathrm{No} Z \\
\mu \mathrm{M} \mathrm{PO}_{4}^{3-} \mathrm{Zn}^{2} \\
\text { counts }\end{array}\end{array}$ & $\begin{array}{l}\mathrm{Zn}^{2+} 65 \mu \mathrm{M} \mathrm{PO}_{4}{ }^{3} \\
+4.4 \mathrm{pM} \mathrm{Cd}^{2+}{ }^{2} \\
\mathrm{n}^{2+} 65 \mu \mathrm{MPO}_{4}^{3-} \\
\text { fold change }\end{array}$ \\
\hline 1982 & PS & $\begin{array}{l}\text { photosystem II chlorophyll-binding } \\
\text { protein CP47 (psbB) }\end{array}$ & $20.1 \pm 0.7$ & $5.1 \pm 3.2$ & +3.9 \\
\hline 0677 & PS & photosystem II D2 protein (psbD1) & $5.2 \pm 1.9$ & $1.4 \pm 0.6$ & +3.7 \\
\hline 0045 & $\mathrm{U}, \mathrm{M}$ & $\begin{array}{l}\text { soluble hydrogenase small subunit } \\
\text { (DHSS) }\end{array}$ & $7.6 \pm 0.2$ & $2.8 \pm 1.4$ & +2.7 \\
\hline 0486 & PS & anchor polypeptide $\mathrm{L}_{\mathrm{CM}}(\mathrm{apcE})$ & $15 . \overline{8} \pm 2.5$ & $6.6 \pm 1.4$ & +2.4 \\
\hline 2227 & $\mathrm{U}, \mathrm{Om}$ & possible porin (som) & $30.7 \pm 7.7$ & $13.1 \pm 1.6$ & +2.3 \\
\hline 1835 & PS & $\begin{array}{l}\text { photosystem I reaction center subunit } \\
\text { III (psaF) }\end{array}$ & $6.2 \pm 0.9$ & $2.8 \pm 1.4$ & +2.2 \\
\hline 0085 & Mo & $\begin{array}{l}\text { cell surface protein required for } \\
\text { swimming motility (swmA) }\end{array}$ & $8.6 \pm 0.3$ & $4.2 \pm 0.6$ & +2.0 \\
\hline 2500 & $\begin{array}{l}\mathrm{M}, \mathrm{Cb}, \mathrm{TCA}, \\
\text { E,C }\end{array}$ & aconitate hydratase $(\mathrm{acnB})$ & $2.4 \pm 0.7$ & $7.5 \pm 0.1$ & -0.3 \\
\hline
\end{tabular}

Arranged in highest to lowest fold change $4.4 \mathrm{pM} \mathrm{Cd}^{2+}$ than $\mathrm{Zn} .+=$ fold greater than $\mathrm{Zn},-=$ fold less than $\mathrm{Zn}$. $\mathrm{PS}=$ photosynthesis, $\mathrm{U}=$ unclassified, $\mathrm{M}=$ metabolism, $\mathrm{Om}=$ outer membrane protein, $\mathrm{Mo}=$ motility, $\mathrm{Cb}=$ carbohydrate metabolism, TCA = citrate cycle, $\mathrm{E}=$ energy metabolism, $\mathrm{C}=$ carbon fixation, in this instance reductive carboxylate cycle. 